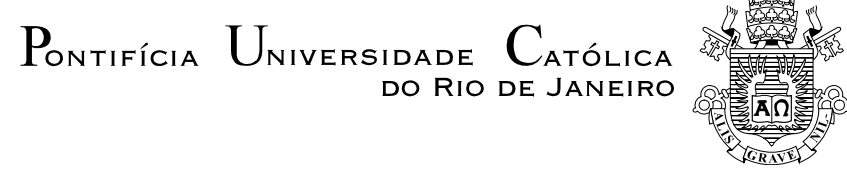

Rosélia Pinheiro de Magalhães

\begin{abstract}
Assistência Estudantil e o seu papel na Permanência dos Estudantes de Graduação: A Experiência da Universidade Federal do Rio de Janeiro
\end{abstract}

Dissertação de Mestrado

Dissertação apresentada ao Programa de PósGraduação em Serviço Social da PUC-Rio como requisito parcial para obtenção do título de Mestre em Serviço Social

Orientador: Profa. Andreia Clapp Salvador

Rio de Janeiro

Agosto de 2013 


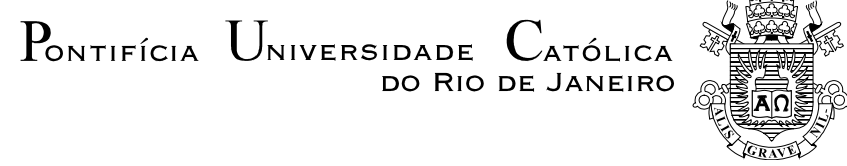

Rosélia Pinheiro de Magalhães

\section{Assistência Estudantil e o seu papel na Permanência dos Estudantes de Graduação: A Experiência da Universidade Federal do Rio de Janeiro}

Dissertação apresentada como requisito parcial para obtenção do grau de Mestre pelo Programa de Pós-Graduação em Serviço Social do Departamento de Serviço Social do Centro de Ciências Sociais da PUC-Rio. Aprovada pela Comissão Examinadora abaixo assinada.

Profa. Andreia Clapp Salvador Orientador Departamento de Serviço Social - PUC-Rio

Profa. Inez Terezinha Stampa Departamento e Serviço Social - PUC-Rio

Prof. Antonio José Barbosa de Oliveira UFRJ

Profa. Mônica Herz

Vice-Decana de Pós-Graduação do Centro de Ciências Sociais - PUUC-Rio

Rio de Janeiro, 21 de agosto de 2013 
Todos os direitos reservados. É proibida a reprodução total ou parcial do trabalho sem autorização da universidade, do autor e do orientador.

\section{Rosélia Pinheiro de Magalhães}

Graduou-se em Serviço Social na UFRJ (Universidade Federal do Rio de Janeiro) em 1985. Trabalhou como Assistente Social da Prefeitura do Rio de Janeiro e no consórcio CEDERJ da Fundação Centro de Ciências e Educação Superior a Distância do Estado do Rio de Janeiro - CECIERJ. Trabalha como Assistente Social e Assessora de Políticas Estudantis na Universidade Federal do Rio de Janeiro/UFRJ. Áreas de interesse: Educação Superior, Assistência Estudantil, Políticas de Permanência e Políticas de Ação Afirmativa.

Ficha Catalográfica

Magalhães, Rosélia Pinheiro de

Assistência estudantil e o seu papel na permanência dos estudantes de graduação: a experiência da Universidade Federal do Rio de Janeiro/ Roselia Pinheiro de Magalhães ; orientadora: Andreia Clapp Salvador. - 2013.

205 f. : il. ; $30 \mathrm{~cm}$

Dissertação (mestrado)-Pontifícia Universidade Católica do Rio de Janeiro, Departamento de Serviço Social, 2013.

Inclui bibliografia.

1. Serviço social - Teses. 2. Assistência estudantil. 3. Educação superior. 4. Desigualdade social. I. Salvador, Andréia Clapp. II. Pontifícia Universidade Católica do Rio de Janeiro. Departamento de Serviço Social. III. Título. 


\section{Agradecimentos}

À Deus, que me dá a força e a coragem para viver cada experiência e cada desafio como oportunidades de aprendizado, de crescimento e de autotransformação.

À PUC-Rio pelo auxílio concedido, o que possibilitou a realização deste trabalho.

Aos professores do Departamento de Serviço Social da PUC-Rio, que proporcionaram a oportunidade de qualificar e ampliar meus conhecimentos.

À minha querida orientadora Prof ${ }^{a}$ Andréia Clapp Salvador, a quem sou grata pela dedicação e carinho com que me orientou e me conduziu na realização deste trabalho.

À Professora Inez Terezinha Stampa e ao Professor Antônio José Barbosa de Oliveira que, gentilmente, aceitaram o convite para compor a banca de apresentação dessa dissertação.

Aos colegas profissionais da UFRJ, em especial os companheiros da Superintendência Geral de Políticas Estudantis, pelo apoio, incentivo e solidariedade e por compartilharem as reflexões e questões que envolvem o tema deste trabalho.

Às amigas e companheiras Verônica, Cristina e Simone por me apoiares nos momentos críticos e difíceis e por não me deixarem desistir desse projeto.

Aos amigos e familiares que me incentivaram a realizar este trabalho e que não me cobraram coerência durante esse período.

Aos alunos que aceitaram participar deste estudo, sem os quais esta pesquisa não teria sido realizada.

A todos que, diretamente ou indiretamente, contribuíram para que este trabalho pudesse ser realizado 


\section{Resumo}

Magalhães, Rosélia Pinheiro de; Salvador, Andreia Clapp. Assistência Estudantil e o seu papel na Permanência dos Estudantes de Graduação: a experiência da Universidade Federal do Rio de Janeiro. Rio de Janeiro, 2013. 205 p. Dissertação de Mestrado - Departamento de Serviço Social, Pontifícia Universidade Católica do Rio de Janeiro.

Este trabalho aborda a temática da assistência estudantil na UFRJ. Tem enfoque particular na percepção dos estudantes moradores da residência estudantil acerca dos programas existentes na universidade destinados a apoiar a permanência dos discentes nos cursos de graduação. Para respaldar o estudo procedeu-se a uma análise da conjuntura atual da educação superior no Brasil no contexto de reestruturação produtiva e da incorporação dos princípios neoliberais no desenvolvimento das políticas sociais. A presente dissertação reflete sobre os conceitos de políticas sociais, cidadania e de desigualdade, condição esta que historicamente caracteriza o acesso a educação superior no Brasil. Aborda também as transformações da educação superior no Brasil a partir do processo de ampliação do campo da educação com as políticas de democratização do acesso, decorrentes do REUNI e da Lei 12.711 que dispõe sobre o ingresso nas universidades federais e nas instituições federais de ensino técnico de nível médio. O trabalho apresenta um breve histórico da assistência estudantil no Brasil e, em especial na UFRJ, onde o seu desenvolvimento culminou com a criação da Superintendência Geral de Políticas Estudantis, no contexto da aprovação do Decreto PNAES. Parte-se do pressuposto de que as políticas de democratização do acesso à universidade pública só se efetivarão se forem acompanhadas de ações que viabilizem a permanência, em especial dos estudantes das classes populares ou dos grupos desiguais que estão ingressando nas universidades. A pesquisa, de natureza qualitativa, foi desenvolvida com estudantes inseridos no programa de moradia que ingressaram na universidade no ano de 2009. Foram realizadas entrevistas semi-estruturadas com 8 estudantes. Os resultados obtidos indicam que os programas de assistência estudantil existentes na UFRJ têm grande importância para a permanência dos estudantes em condição de desigualdade 
social e econômica. Apontam também para a necessidade de ampliação tanto quantitativa quanto qualitativa dos diversos serviços que compõem os programas de assistência estudantil.

\section{Palavras-chave}

Assistência Estudantil; Educação Superior; Desigualdade Social. 


\section{Abstract}

Magalhães, Rosélia Pinheiro de; Salvador, Andréia Clapp (Advisor). Student assistance and its role in the permanence of Undergraduate Students: The Experience of the Federal University of Rio de Janeiro. Rio de Janeiro, 2013. 205 p. MSc. Dissertation - Social Service Department, Pontifical Catholic University of Rio de Janeiro.

This study addresses the issue of student assistance at UFRJ. It has a particular focus on the perceptions of students who live in the student residence about existing programs at the university to support the stay of students in undergraduate courses. To support the study, an analysis of the current situation of higher education in Brazil in the context of productive restructuring and incorporation of neoliberal principles in the development of social policies was performed. This essay reflects on the concepts of social policy, citizenship and inequality, conditions that historically characterizes the access to higher education in Brazil. It also discusses the transformations of higher education in Brazil since the process of expansion of the education field with the policies of democratization of access arising from REUNI and Law 12.711 which describes the admission into federal universities and the federal institutions of technical high school education. The paper presents a brief history of student assistance in Brazil and especially in UFRJ, where its development resulted in the creation of the General Superintendent of Student Policies in the context of the approval of Decree PNAES. It is assumed that the policies of democratizing the access to public universities will only be successful if accompanied by actions that facilitate the stay, especially for students of social classes with economic difficulties or the unequal groups that in entering universities. The research is qualitative and it was developed with students, placed in housing program, who joined the university in 2009. Semi-structured interviews with eight students were performed. The results show that the exisiting student assistance programs at UFRJ have a great importance for the permanence at the university of students that are inserted in a condition of social and economic inequality. The data also indicate the need for 
both quantitative and qualitative expansion of the various services that compose the student assistance programs.

\section{Keywords}

Student Assistance; Higher Education; Social Inequality. 


\section{Sumário}

Introdução

1. Educação Superior no Brasil 21

1.1. Políticas Sociais e Educação Superior 26

1.2. Cidadania no Brasil e a Desigualdade no

Acesso à Educação

1.3. As Políticas para a Educação Superior no Brasil:

algumas considerações

2. A Assistência Estudantil e seu Papel para a

Permanência na Educação Superior

2.1. Assistência Estudantil no BRASIL - breve histórico

2.2. Assistência Estudantil na Conjuntura do PNAES

2.3. Assistência Estudantil na UFRJ: dois momentos e dois contextos

2.3.1. Assistência Estudantil na UFRJ - um 1ํ․ momento

74

2.3.2. Assistência Estudantil na UFRJ - um $2^{\circ}$. momento e uma nova política

3. A Assistência Estudantil da UFRJ na Perspectiva do Estudante

3.1. O Perfil do Estudante Entrevistado

3.2. A Permanência na Universidade: facilidades e dificuldades

3.3. O Olhar do Estudante sobre a Assistência

Estudantil da UFRJ: o que se conhece?

3.4. Avaliação dos Programas: o que pensam os estudantes?

102

4. Considerações Finais 
6. Apêndices 123

6.1. Roteiro de Entrevistas 123

6.2. Termo de Consentimento Livre e Esclarecido 125

7. Anexos 126

7.1. Anexo 1-Matérias de Jornais 126

7.2. Anexo 2 - Serviço de Assistência e Orientação ao

Estudante da UFRJ - Projeto de Implantação 130

7.3. Anexo 3 - Projeto da Divisão de Assistência ao

Estudante - DAE

7.4. Anexo 4 - DAE: condições para a atuação emergencial e calendário de atividades

7.5. Anexo 5 - Subsídios para uma Proposta de Política de Assistência Estudantil 


\section{Lista de Tabelas e Quadros}

Tabela 1- Percentual de jovens com idade de 18 a 24 anos segundo a renda familiar e o acesso à educação

Brasil, 2009

Tabela 2- Renda Familiar

86

Quadro 1 - Alteração em relação ao local de origem do estudante que tem sido atendido pelo programa de moradia estudantil 


\section{Lista de Gráficos}

Gráfico 1- Sexo $\quad 85$

Gráfico 2- Raça $\quad 85$

Gráfico 3- Grau de Escolaridade da Mãe 87

Gráfico 4- Grau de Escolaridade do Pai 88 


\section{Lista de Abreviaturas}

ANDIFES - Associação Nacional de Dirigentes das Instituições Federais de Ensino Superior

DAE/A - Departamento de Assistência ao Estudante

DAE/B - Divisão de Assistência ao Estudante

CAPES - Coordenação de Aperfeiçoamento de Pessoal de Nível Superior COAA - Comissão de Orientação e Acompanhamento Acadêmico

ENEM - Exame Nacional de Ensino Médio

FIES - Financiamento Estudantil

FONAPRACE - Fórum Nacional de Pró Reitores de Assuntos

Comunitários e Estudantis

HU - Hospital Universitário

IFES - Instituto Federal de Ensino Superior

INEP - Instituto Nacional de Estudos e Pesquisas

LDB - Lei de Diretrizes e Bases

PNE - Plano Nacional de Educação

PDE - Plano de Desenvolvimento da Educação

MEC - Ministério da Educação e Cultura

PIBID - Programa Institucional de Bolsa de Iniciação à Docência

PNAD - Plano Nacional de Amostragem de Domicílio

PNAES - Plano Nacional de Assistência Estudantil

PROUNI - Programa Universidade para Todos

PVNC - Pré-Vestibular para Negros e Carentes

REUNI - Plano de Reestruturação e Expansão das Universidades

Federais

RU - Restaurante Universitário

SINTUFRJ - Sindicato dos Trabalhadores da Universidade Federal do Rio de Janeiro

SISU - Sistema Integrado de Seleção Unificada

SUPEREST - Superintendência Geral de Políticas Estudantis

UERJ - Universidade do Estado do Rio de Janeiro 
UFF - Universidade Federal Fluminense

UFABC - Universidade Federal do ABC

UFBA - Universidade Federal da Bahia

UFRJ - Universidade Federal do Rio de Janeiro

UNB - Universidade de Brasília

UNE - União Nacional de Estudantes

UNESCO - Organização das Nações Unidas para a Educação, Ciência e Cultura. 
O intelectual divergente considere-se ou não parte da burguesia, tem de seguir outro caminho. Para explicarse ele precisa começar pela verdade - não uma parte da verdade, mas toda a verdade. Todavia, fazer isso não é o mesmo que procurar uma justificação... De nada adiantaria uma retórica ultra-radical, de condenação e expiação: o intelectual não cria o mundo no qual vive. Ele já faz muito quando consegue ajudar a compreendê-lo e a explicá-lo, como ponto de partida para a sua alteração real.

(Florestan Fernandes) 


\section{Introdução}

As recentes políticas de democratização do acesso ao ensino superior público trouxeram à tona a questão da assistência estudantil, tirando-a da posição secundária e marginal a qual foi historicamente relegada nas universidades públicas. Nunca se falou tanto sobre temas como assistência estudantil, políticas de permanência e políticas de ação afirmativa como mecanismos fundamentais para a efetivação do direito à educação para jovens oriundos de classes populares e de grupos desiguais.

A assistência estudantil não é fenômeno novo nas universidades públicas. Entretanto, assumiu novas determinações a partir das políticas de democratização do acesso que vem sendo implementadas na última década. No caso da Universidade Federal do Rio de Janeiro UFRJ, campo empírico onde se desenvolveu a pesquisa que originou este trabalho, há registros onde se constata a existência de programas de assistência estudantil desde a década de 70. As principais ações que se mantiveram ao longo desses 40 anos, referem-se à moradia estudantil e às bolsas de ajuda financeira, programas destinados a estudantes com dificuldades socioeconômicas para realizar a graduação.

A universidade brasileira sempre foi instituição elitizada e a educação superior um privilégio das classes mais favorecidas economicamente e com acesso a formação escolar de qualidade. Durante décadas predominou a desigualdade no acesso à universidade pública que esteve ocupada, prioritariamente, pelos jovens pertencentes às classes alta e média-alta do país. Diante desse quadro, a assistência estudantil desenvolvida na UFRJ caracterizouse por ações pontuais e focalizadas, definidas pela escassez de recursos financeiros e, em geral, associada à conjuntura política e social do país.

$\mathrm{O}$ fato de não ser considerada como parte integrante do processo de formação acadêmica fez com que a assistência estudantil fosse desenvolvida a partir de uma cultura paternalista e clientelista, destinada a um pequeno segmento dos estudantes que demandava respostas para problemas emergenciais. A assistência estudantil da UFRJ constituiu-se, durante muito tempo, num conjunto 
de práticas desarticuladas do projeto de formação acadêmica do estudante e não referenciada na perspectiva dos direitos de cidadania, mas sim sob a cultura da dádiva e da benesse, resultado das características de formação da sociedade brasileira.

A conjuntura política instaurada com o processo de redemocratização do país na década de 80 e, que culmina com a aprovação da Constituição de 1988, cria possibilidades de ampliação de direitos sociais para todos os cidadãos. Esse é um período em que os movimentos sociais se reorganizam e buscam a efetivação do acesso e usufruto de direitos sociais como medida necessária a reversão do quadro de desigualdade social que predominou historicamente no Brasil.

A despeito da conjuntura de consolidação da democracia e de ampliação da cidadania que promovem a garantia formal dos direitos sociais e a sua efetivação, ainda que de forma precária, o Brasil iniciou a década de $90 \mathrm{com}$ um processo de reformas em todas as esferas da vida pública, onde as políticas sociais e econômicas ficaram submetidas aos princípios do neoliberalismo.

A área educacional é um dos setores que é diretamente influenciada pelas enormes transformações econômicas e sociais desse período, tornando-se alvo de reformas para adequação ao novo padrão de acumulação financeira determinado pelas políticas de cunho neoliberal.

Em relação à educação superior, considerada elemento fundamental para o desenvolvimento tecnológico e científico para adequação às exigências das transformações do modo de produção e inserção do Brasil no mundo globalizado, também se verificam várias mudanças. Tais mudanças, fundamentadas em estudos que consideram a educação como principal estratégia para redução das desigualdades sociais e econômicas, foram dirigidas, em especial, à necessidade de mão de obra especializada, a uma maior qualificação profissional para inserção no mundo do trabalho, pautado pela concorrência e pelo paradigma da empregabilidade e pela elevação dos índices de escolarização da população.

Como descrito por Silva Junior:

Essas profundas mudanças educacionais estariam formando a população brasileira em processos cognitivos, nos necessários conteúdos postos pela mundialização do capital, tornando cada cidadão apto para o trabalho (competente e empregável) e preparando um novo cidadão critico para o mundo globalizado. (Silva Junior, 2005, p.14) 
Desse modo, verifica-se uma redefinição da forma como as políticas educacionais passam a ser desenvolvidas, com base no novo paradigma orientado pelos organismos internacionais e voltado para as necessidades e exigências do mercado.

Diante dessa realidade, o estado brasileiro aprova em 2001 o Plano Nacional de Educação - PNE que tem por objetivos a elevação dos níveis de escolaridade da população, a melhoria da qualidade do ensino em todos os níveis, a redução das desigualdades sociais e regionais no acesso e permanência na educação pública, dentre outros.

Para a educação superior o PDE prevê, entre outras metas, a elevação e ampliação do acesso às universidades públicas e estabelece que: "há necessidade da expansão das universidades públicas para atender à demanda crescente dos alunos, sobretudo os carentes" (MEC-PNE, 2001). Cabe ressaltar, que a proposta final do PNE aprovado pelo governo difere bastante e em pontos fundamentais, como, por exemplo, na questão do orçamento para a execução das ações, do projeto que vinha sendo discutido pelos diversos setores da sociedade civil.

Para promover a expansão do ensino superior no setor público, o principal programa criado pelo governo é o REUNI que é instituído em 2007 nas universidades públicas como parte do Plano de Desenvolvimento da Educação PDE. No final desse mesmo ano o governo federal instituiu, por meio da Portaria Normativa no. 39 de 12 de dezembro de 2007, o Programa Nacional de Assistência Estudantil - PNAES.

O PNAES coloca a assistência estudantil numa nova perspectiva dentro das instituições federais de educação principalmente por estabelecer destinação de recursos financeiros específicos para os programas existentes e para a criação de novos. Para o ano de 2008 o Ministério da Educação destina R 126 milhões para o PNAES e para o ano de 2009, o montante é de R\$ 200 milhões. Embora insuficiente diante da precariedade de anos em relação aos investimentos para a assistência estudantil e, da necessidade de ampliação das ações mediante o aumento das vagas, esses recursos possibilitam que, pela primeira vez esse setor não precise disputar recursos mínimos com as demais áreas - ensino, pesquisa, extensão - das universidades.

Além disso, o governo ao estabelecer os princípios norteadores do PNAES, reconhece ser a desigualdade social um obstáculo à realização da 
formação superior para as pessoas das classes populares e considera a assistência estudantil como estratégia central para a redução dessas desigualdades.

É importante ressaltar que a criação de políticas sociais como mecanismos para a efetivação de direitos sociais é um processo longo e gradativo, marcado por contradições e por disputas em torno de interesses diversos. Nesse processo há que se considerar o papel fundamental dos movimentos sociais como representantes de grupos que reivindicam o acesso aos direitos.

No campo da educação superior, destacam-se dois importantes segmentos da sociedade que vem se mobilizando há pelo menos 2 décadas em torno do tema: representações do movimento negro, grupo social historicamente excluído do direito à educação, que teve como principal ponto de discussão a questão do acesso à universidade e que foi o principal protagonista da implementação das políticas de ação afirmativa para ingresso nas universidades. $\mathrm{O}$ outro segmento refere-se aos profissionais e dirigentes das universidades federais que compõe desde o final dos anos 80 o Fórum Nacional de Pró-Reitores de Assuntos Comunitários e Estudantis - FONAPRACE. Este fórum tem, no tema da assistência estudantil, seu principal foco de debate por considerá-lo como mecanismo imprescindível para a efetivação do direito a educação superior, em especial para os estudantes em condição de desigualdade social.

Tendo em vista a inserção profissional da autora desde a década de 90 na Divisão de Assistência ao Estudante da UFRJ e a participação há 10 anos nas reuniões do FONAPRACE, a assistência estudantil praticada na UFRJ foi escolhida como objeto de estudo desse trabalho. Para entender de que forma a assistência estudantil tem atuado na trajetória dos estudantes de graduação na UFRJ buscamos abordar algumas questões que nos pareceram importantes para o estudo: a política de educação no Brasil; a desigualdade no acesso à educação e a questão da permanência como mecanismo central para a efetivação do direito à educação.

Diante da intenção de investigar a importância que a assistência estudantil tem para a permanência qualificada de um segmento de estudantes na universidade avaliamos ser fundamental conhecer a visão dos principais sujeitos desse processo: os estudantes que acessam alguns dos programas existentes na UFRJ. 
Assim, buscando identificar o conhecimento e a avaliação que os estudantes têm sobre os programas de assistência estudantil da UFRJ e a forma como esses programas têm atuado na trajetória acadêmica dos mesmos, optou-se por realizar uma pesquisa de natureza qualitativa com estudantes atendidos pelo programa de moradia estudantil.

Desse modo, foram realizadas nos meses de dezembro de 2012 e janeiro de 2013 oito (8) entrevistas semi-estruturadas e com roteiro previamente elaborado, representando $10 \%$ do universo escolhido. Definiu-se como universo da pesquisa estudantes de graduação, moradores da residência estudantil e que ingressaram na UFRJ no ano de 2009, o que totalizava a época das entrevistas setenta e dois (72) estudantes. Cabe ressaltar que a escolha dos entrevistados se deu de forma aleatória e para conseguir realizar as oito (8) entrevistas foram contatados por email e/ou telefone trinta (30) estudantes.

As entrevistas realizadas foram gravadas, transcritas e analisadas resultando num material consistente e de grande relevância para o entendimento do papel da assistência estudantil na trajetória universitária dos estudantes da UFRJ.

O programa de expansão das universidades públicas vem possibilitando uma ampliação do ingresso de estudantes pertencentes aos grupos socialmente excluídos. No entanto, o entendimento que norteou este estudo é de que a inclusão social na educação superior não se efetivará somente com as políticas de democratização do acesso, em especial para as pessoas oriundas das classes populares e dos grupos desiguais. Para estes grupos, a garantia do direito à educação somente se concretizará com a existência de uma efetiva e ampliada política de assistência estudantil que viabilize as condições necessárias para uma permanência e uma trajetória universitária bem sucedida. 


\section{1}

\section{Educação Superior no Brasil}

Assistência estudantil é hoje uma das questões mais relevantes quando se fala de democratização da educação superior pública e tem sido alvo de debates e reivindicações que levaram à criação de políticas e dispositivos legais para a sua implementação e/ou ampliação, a partir do reconhecimento de sua importância para a efetivação do direito à educação. Para a análise dessa temática e de seu papel para a permanência na universidade pública, objeto do presente estudo, consideramos necessário um estudo preliminar sobre os conceitos de Políticas Públicas e Educação.

$\mathrm{Na}$ última década vem aumentando o ingresso de estudantes nas universidades públicas e privadas no Brasil devido às políticas voltadas para a democratização do acesso ao ensino superior. Isto se deve a diversos fatores e, no caso das universidades federais, essa política de ampliação do acesso ocorre principalmente através do Plano de Reestruturação e Expansão das Universidades federais - REUNI e das Políticas de Ação Afirmativa para a inserção de estudantes de grupos desiguais no ensino superior, dentre outras.

Porém o que tem se verificado é que o ingresso na universidade é apenas a primeira etapa da formação superior. Para um segmento dos jovens que ingressa na universidade, especialmente os oriundos de grupos populares, o desafio maior é ter condições para permanecer e concluir essa formação. A permanência na universidade e a realização do curso envolvem o atendimento a necessidades diversas que vão desde o apoio financeiro para se alimentar, para transporte e aquisição de material didático, até o suporte de acompanhamento de saúde, pedagógico e o atendimento de condições para alunos com deficiência.

Nosso entendimento é de que as políticas de expansão do acesso ao ensino superior público devem ser acompanhadas de um conjunto de ações que, materializadas em políticas públicas, possibilitem a permanência e realização do curso superior para todos os segmentos sociais que desejem realizar esta etapa da formação educacional. A criação de uma política de permanência na educação 
superior é condição fundamental para que haja uma efetiva democratização da universidade.

O tema da assistência estudantil vem ganhando destaque no debate contemporâneo nos últimos 5 anos, decorrência da grande atenção dada pelo Estado às políticas educacionais, sobretudo no que se refere à ampliação do acesso à educação superior.

A política de educação vem sofrendo alterações ao longo da $2^{\mathrm{a}}$. metade do século passado. Tais mudanças na formação técnica e educacional vieram para atender às necessidades do processo de reestruturação produtiva decorrentes da crise de acumulação do capitalismo mundial. Na década de 70 o Brasil vivenciou esse período com o fim do chamado "milagre econômico" e promoveu uma redefinição dos objetivos e da estrutura do sistema educacional. O patamar mínimo de escolarização, por exemplo, alterou-se de quatro para oito anos a partir dos anos 70. (Neves \& Fernandes, 2002)

Essa nova configuração do mundo do trabalho e a adoção dos princípios neoliberais para os programas de desenvolvimento da nação se consolidam no decorrer da década de 80 e 90 com repercussão em todos os níveis das relações sociais.

No que se refere ao sistema educacional Neves e Fernandes (2002) afirmam que:

\begin{abstract}
Este novo estágio do processo civilizatório, que inaugura um novo nexo entre ciência, vida e ciência e trabalho e entre saber e poder vem requerendo a formação de intelectuais de novo tipo. As reformas dos sistemas educacionais no mundo, e também no Brasil, têm nas repercussões técnicas e ético-políticas da atual reestruturação produtiva uma importante determinação (2002, p.22)
\end{abstract}

O que significa que há necessidade de um sistema educacional que seja voltado à formação deste novo tipo de profissional que é requisitado pelas mudanças do mundo do trabalho e pelas novas formas de organização da produção.

A partir da década de 90, as transformações do modo de produção se intensificam com a crescente incorporação dos princípios do neoliberalismo aos projetos de desenvolvimento econômico e social e, a educação, como as demais políticas sociais e econômicas, é fortemente influenciada por essa ideologia. Este 
é um período em que a esfera educacional torna-se alvo de muitas mudanças quantitativas e qualitativas por parte do Estado, que promove reformas em todos os níveis da formação escolar a fim de atender ao novo paradigma do mundo do trabalho.

No que se refere ao ensino superior dentre as diversas transformações que o Estado promove a partir da década de 90, a ampliação do acesso foi uma das mais propagadas, ainda que, essa ampliação tenha se dado prioritariamente pela via do setor privado.

A expansão das instituições privadas de ensino superior foi motivada, entre outros fatores, pela redefinição do papel da educação em todos os seus níveis, mas principalmente da educação superior, diante das novas determinações produtivas. Para a ideologia neoliberal o principal objetivo da educação superior é o de contribuir para o aumento da produtividade e da competitividade no mundo do trabalho, considerando desnecessária a produção nacional de conhecimento cientifico e tecnológico e prescindindo, portanto, da forma de organização educacional que prevê a indissociabilidade entre ensino, pesquisa e extensão.

Como afirma Neves e Fernandes (2002):

A educação superior, por sua vez, passa a ter como prioridades, a partir de então, capacitar a força de trabalho para adaptar a tecnologia produzida no exterior e conformar este novo trabalhador qualificado às novas exigências da cultura empresarial, especialmente no que tange à aceitação, como naturais, das desigualdades sociais, da competição acirrada entre indivíduos, grupos e classes e da perda dos seus direitos conquistados ao longo da História (2002, p.26)

Tratava-se naquele momento de uma política que exigia não somente mudanças qualitativas, mas principalmente quantitativas como o aumento do número de vagas nas universidades o que aconteceu principalmente no setor privado pelas características da formação profissional que o mercado estava demandando.

No entanto, na análise desse processo de aumento do número de vagas no ensino superior há que se considerar a correlação das forças sociais em relação às reivindicações educacionais. Nesse sentido, essa ampliação do acesso a educação superior também veio de encontro aos interesses e demandas de setores da 
sociedade civil que tem na educação um dos pontos principais para a redução das desigualdades sociais no Brasil.

Numa breve análise da formação histórica do Brasil, sem contar as experiências dos demais países da América Latina, tem-se vários momentos em que a educação foi objeto das reivindicações dos movimentos sociais. Para Gohn (2011) “as lutas e movimentos pela educação têm caráter histórico, são processuais e ocorrem dentro e fora das escolas como também em outros espaços institucionais" num processo que faz parte da construção da cidadania e da garantia de direitos. É inquestionável o papel que os movimentos sociais tiveram na conquista dos direitos sociais, dentre eles a educação, garantidos na Constituição de 1988.

Segundo Gohn:

A relação movimentos sociais e educação foi construída a partir da atuação de novos atores que entravam em cena, sujeitos de novas ações coletivas que extrapolavam o âmbito da fábrica e dos locais de trabalho, atuando como moradores das periferias da cidade, demandando ao poder público o atendimento de suas necessidades para sobreviver no mundo urbano (2011, p.334).

Se considerarmos apenas a $2^{\mathrm{a}}$. metade do século $\mathrm{XX}$ teremos vários exemplos de lutas e movimentos em prol da educação, seja pelo direito ao acesso a educação escolarizada nos seus vários níveis seja pela possibilidade de que essa formação não fosse feita apenas pela ótica da classe dominante. A título de exemplificação, podemos citar, nos anos 60 e 70, os movimentos das Ligas Camponesas e a utilização do método Paulo Freire, a mobilização dos estudantes universitários (UNE) em 1968 e as experiências das Comunidades Eclesiais de Base (Gohn, 2011).

Em relação às conquistas no que se refere ao ensino superior que culminou com a recente aprovação da Lei 12.711/2012 que instituiu a Política de Ação Afirmativa para ingresso nas universidades públicas, teve papel fundamental o movimento pelo direito à educação superior iniciado nos anos 90 com a criação dos pré-vestibulares para negros e carentes - PVNCs. Esses cursos comunitários visavam capacitar jovens pobres e, em especial, negros para participação nos processos seletivos para ingresso nas universidades sendo considerado por Vieira 
(2010) como um dos "marcos fundadores" do movimento pela criação das políticas de ação afirmativa no Brasil.

Ainda nos anos 90 temos, na própria Universidade Federal do Rio de Janeiro - UFRJ, a criação de um pré-vestibular vinculado ao sindicato dos trabalhadores (SINTUFRJ) e destinado à preparação dos funcionários e de seus filhos para ingresso no ensino superior.

Outros eventos ocorridos entre os anos 90 e 2000 tiveram papel importante para a problematização do ensino superior, como a elaboração do Programa Nacional de Direitos Humanos, documento elaborado em 1996 e enviado pelo Governo Brasileiro à ONU, considerado documento referência para o combate às desigualdades raciais no Brasil; a aprovação em 2001 da lei estadual 3.708 que dispunha sobre reserva de vagas para negros para ingresso na Universidade do Estado do Rio de Janeiro - UERJ e a Conferência Mundial contra o Racismo, Discriminação Racial, Xenofobia e Intolerâncias Correlatas ocorrida na África do Sul, também em 2001.

Esses fatos demonstram o papel que os movimentos sociais tiveram no debate sobre a desigualdade social no acesso à educação superior e na definição e adoção por parte do Estado de políticas de ampliação desse nível de escolaridade. Cabe ressaltar, que o debate sobre "cotas raciais" nas universidades iniciado pelo movimento negro abriu espaço para que outros grupos igualmente excluídos pudessem ter direito à formação superior consolidando definitivamente o estabelecimento de políticas de ação afirmativa como mecanismo de diferenciação para ingresso nas universidades.

Assim, as políticas de ampliação do acesso à educação superior não são apenas resultado das exigências impostas pela ideologia neoliberal para o atendimento às necessidades da nova estruturação do capital. Elas surgem também como demandas de setores da sociedade que consideram que a possibilidade de ingressar na universidade e obter a formação superior são condições para que haja uma promoção da igualdade social numa inequívoca demonstração do caráter contraditório na dinâmica de constituição de uma determinada política social.

Para Pereira (2011) são estas características contraditórias da política social que possibilitam que as classes populares possam ser beneficiadas a despeito das demais intenções que as motivaram.

Para a autora a política social: 
(...)jamais poderá ser compreendida como um processo linear, de conotação exclusivamente positiva ou negativa, ou a serviço exclusivo desta ou daquela classe. Na realidade, ela tem se mostrado simultaneamente positiva e negativa e beneficiado interesses contrários de acordo com a correlação de forças prevalecente (...). (2011, p.166)

A despeito da contradição entre os interesses do Estado como representante do capital financeiro e os interesses dos grupos sociais desiguais, acreditamos que a educação superior tem um papel central para a redução dos níveis de desigualdade social no Brasil, na obtenção de melhores condições de vida e numa maior inserção e participação nas questões sociais da modernidade concretizando, deste modo, uma efetivação dos direitos sociais.

\section{1. \\ Políticas Sociais e Educação Superior}

A educação enquanto instrumento fundamental para a reversão das desigualdades sociais e para se alcançar a cidadania, conforme estabelecido na Constituição de 88 tem sido um dos principais temas de debate entre a sociedade civil e o Estado principalmente no que se refere à democratização do acesso ao ensino superior.

Durante a segunda metade dos anos 90 as reivindicações dos movimentos sociais estavam voltadas principalmente pela garantia do acesso à educação superior para segmentos sociais dos grupos desiguais, como os negros, indígenas e aqueles oriundos das classes populares. Apesar dos avanços obtidos nesta questão, a universidade pública brasileira permanece, nos dias atuais, como um espaço destinado e ocupado majoritariamente por pessoas das classes dominantes. No entanto, esse quadro começa a ser alterado com o ingresso cada vez maior nas universidades públicas de pessoas oriundas desses grupos desiguais decorrência das recentes políticas de democratização da educação superior, como, por exemplo, as políticas de ação afirmativa.

A presença crescente de estudantes em condição de desigualdade de diversos níveis tem levado a que a assistência estudantil, que até então se 
restringia a programas focalizados e dependentes da vontade política e da sensibilidade dos gestores com a questão da inclusão social, seja pensada enquanto política social de permanência necessária à concretização do direito à educação superior.

Dentre as políticas voltadas para o ensino superior que o Estado vem implementando destacam-se aquelas voltadas para a ampliação do acesso, como a expansão das vagas nas universidades públicas e as que visam apoiar a permanência como os programas de assistência estudantil.

Neste item faremos algumas considerações acerca da categoria de política social enquanto modalidade da política pública a fim de fundamentar nossa discussão sobre a necessidade de que a assistência estudantil nas universidades federais se transforme em política pública de permanência.

Nosso entendimento é de que a construção dessa política é um desafio a ser enfrentado para a redução e/ou reversão das condições de desigualdade social que os estudantes dos grupos desiguais encontram no espaço da universidade e que podem impedir a realização de uma formação acadêmica superior de qualidade.

Numa breve revisão da literatura pode-se perceber que as políticas sociais são, em geral, resultado da relação do Estado com a sociedade civil, num processo que tem caráter contraditório e complexo e que tem relação direta com as contradições do modo de produção capitalista. Mas, a política social também se configura como um instrumento de garantia de direitos e de ampliação da cidadania entendida como capacidade dos indivíduos de se apropriarem dos bens socialmente criados.

Quer dizer, a política social é uma dimensão que tem um duplo viés, pois embora ela represente ações do Estado resultantes das pressões de grupos específicos e com interesses particulares ela também visa garantir a efetivação de direitos sociais legalmente constituídos para o conjunto da sociedade civil. Enquanto conquista da classe trabalhadora (Coutinho, 1997) torna-se importante instrumento para a consolidação e o fortalecimento da cidadania e da democracia.

Para Coutinho (1997) este processo de ampliação da cidadania através das garantias legais que se obtém das políticas sociais é etapa fundamental para a materialização dos direitos. 
A presença de tais direitos nas Constituições, seu reconhecimento legal, não garante automaticamente a efetiva materialização dos mesmos. Esse é, particularmente, o caso do Brasil. Mas, embora a conversão desses direitos sociais em direitos positivos não garanta sua plena materialização, é muito importante assegurar seu reconhecimento legal, já que isso facilita a luta para torná-los efetivamente um dever do Estado (Coutinho, 1997, p. 156)

Para uma maior compreensão das políticas sociais entendemos ser necessária uma breve análise sobre o conceito de Estado uma vez que este é o campo onde estas políticas se materializam como resultado das disputas e pressões de interesses diversos.

Nesse campo não há neutralidade e as relações são contraditórias, pois o Estado ao implementar as políticas sociais ao mesmo tempo em que exerce controle sobre a sociedade também é controlado por ela. O Estado, quando confrontado pelos movimentos sociais organizados para o atendimento de suas demandas, implementa ações que podem ser do interesse da maioria da população ou de grupos específicos. ${ }^{1}$

Dentre as diversas concepções teóricas existentes para o estudo do conceito de Estado, optamos pela que considera que sua existência e caracterização devem levar em conta fatores históricos e relacionais.

Enquanto processo histórico, o Estado assume configurações diversas dependendo da organização da sociedade num determinado momento.

Para Pereira (2011)

"O Estado é um fenômeno histórico porque ele não existe de forma absoluta e inalterável, ou sujeito a uma ordem cujos valores e fins estejam previamente definidos... Trata-se, portanto de algo em movimento e em constante mutação e, por isso, um fenômeno que tem que ser pensado e tratado como um processo" (p.144)

Ou seja, o estudo e a análise do Estado e de suas funções na atualidade devem considerar os aspectos que o caracterizaram no passado incorporando a estes, as novas determinações conjunturais e as diferentes configurações que assume em função da correlação de forças existente conformando, desse modo, um processo inacabado e em permanente mudança.

\footnotetext{
${ }^{1}$ Para um estudo mais aprofundado de diferentes abordagens teóricas sobre o conceito de Estado e sua relação com a sociedade e com a política social ver PEREIRA, Potyara A.P. Política Social: Temas e questões, S.Paulo: Cortez, 2011
} 
Ademais, essa concepção apresenta o Estado como um fenômeno que só existe mediante as relações que estabelece com a sociedade, relação que se caracteriza como contraditória e recíproca, numa interação dialética e complexa.

Conforme Pereira:

A relação dialética realizada pelo Estado comporta simultaneamente antagonismos e reciprocidades e, por isso, permite que forças desiguais e contraditórias se confrontem e interajam de tal forma que uma deixa sua marca na outra e ambas contribuem para um resultado final (2011, p. 146)

Partindo desta concepção, entendemos que um Estado que se pretenda democrático, para se manter e ter legitimidade precisa representar e acatar os interesses e as reivindicações dos diversos segmentos da sociedade embora cumpra este papel sem neutralidade já que, historicamente, sua atuação tem sido atender, prioritariamente, aos interesses das classes dominantes.

Há uma relação de interdependência entre a sociedade e o Estado e, este precisa administrar os diversos interesses em jogo se constituindo no que foi definido como:

"uma condensação de relações de poder, isto é uma condensação de forças identificada como um bloco no poder ou como um pacto de dominação que exerce seu domínio por meio de um aparato institucional (burocrático, jurídico, policial, ideológico) sobre a sociedade, embora seja influenciado por esta" (Poulantzas apud Pereira, 2011, p. 147)

Quer dizer, embora o Estado se identifique predominantemente com os interesses das classes dominantes, relaciona-se com toda a sociedade e atua como mediador desses interesses antagônicos atendendo parte das demandas das classes populares a fim de manter o controle e a organização da sociedade.

Para controlar e gerir as necessidades, interesses e objetivos diversos da sociedade e dos diferentes grupos sociais que a compõe o Estado implementa ações que se materializam em políticas públicas.

No presente trabalho será considerada a definição de política pública como aquela "que privilegia a relação dialeticamente contraditória entre Estado e sociedade como o fermento da constituição e processamento dessa política" (Pereira, 2008). Ou seja, as políticas públicas são decisões e procedimentos que o 
Estado implementa a partir das pressões e demandas da sociedade civil e envolve negociações, mediações e o atendimento de interesses universais ou particulares.

Pereira (2008) esclarece que não é o fato de ser implementada pelo Estado que caracteriza uma política como pública e sim e a sua abrangência e o fato de representar uma opção pautada pelo interesse comum, estando destinada a todos os membros de uma sociedade que "se faz presente, ganhando representatividade, poder de decisão e condições de exercer o controle sobre sua própria reprodução e sobre os atos e decisões do governo" $\left(2008\right.$, p.94). ${ }^{2}$.

A política de educação superior pública no Brasil, campo de estudo deste trabalho, embora tenha se constituído como uma política de educação sob responsabilidade do Estado, não corresponde às características definidas pela autora para política pública. No Brasil, este nível de formação esteve desde sua gênese voltada prioritariamente para jovens pertencentes aos segmentos sociais mais favorecidos economicamente, não se caracterizando como uma política abrangente e pautada pelo bem comum. Isto se dá principalmente porque o campo da educação superior é uma arena de interesses e conflitos, especialmente por se tratar de uma esfera que possibilita ascensão social e econômica e é marcada por sua funcionalidade para a manutenção da estrutura social desigual.

A partir das políticas de democratização do ensino superior - REUNI, PROUNI e Políticas de Ação Afirmativa - o ingresso de pessoas das camadas populares nas universidades públicas do Brasil vem crescendo gradualmente na última década. Essa tendência de crescimento corresponde, por um lado, às metas do governo previstas no Plano Nacional de Educação/PNE 2011-2020 de elevação de $33 \%$ do número de jovens de 18 a 24 anos matriculados na educação superior. Por outro lado, vai de encontro às reivindicações de setores da sociedade civil que tem na educação uma das principais questões para a redução das desigualdades sociais no Brasil.

Desse modo, com as atuais políticas públicas para a ampliação da educação superior, não serão somente os jovens das classes dominantes que ocuparão este espaço, mas também os jovens oriundos dos grupos desiguais terão direito de acessar esse nível da formação acadêmica, numa demonstração do

\footnotetext{
${ }^{2}$ Pereira (2008) esclarece que a palavra pública, que sucede a palavra política, tem maior identificação com a expressão latina res publica, isto é res (coisa) publica (de todos) do que somente com o Estado.
} 
caráter contraditório que caracteriza a relação entre os interesses do Estado e da sociedade.

Netto (2007) analisando a situação social e econômica do Brasil e dos países da America Latina no início desse século XXI considera que a atual fase do capitalismo mostra-se cada vez menos capaz de suportar "reformas viabilizadoras da ampliação de direitos sociais" (2007, p.148) e embora considere as conquistas sociais e políticas obtidas no decorrer do século XX afirma a permanência da pobreza e da desigualdade como condições estruturantes da nova ordem social.

Segundo Netto:

A análise da permanência da pobreza e da desigualdade - malgrado todas as políticas, planos e programas chamados a combatê-las - tem de ser conduzida considerando que tal permanência, produto necessário da acumulação capitalista, se opera ao mesmo tempo em que se acentuam os processos de concentração da propriedade e das decisões políticas (2007, p.157).

O autor destaca a necessidade de uma análise acerca da influência e da pressão que a política neoliberal exerce especialmente sobre os países periféricos para o entendimento dos limites estruturais das atuais políticas de combate à pobreza e à redução das desigualdades.

Para Netto (2007)

O poder de pressão das instituições internacionais sobre os Estados capitalistas mais débeis é enorme e lhes permite impor desde a orientação macroeconômica, com os chamados ajustes estruturais, até providências e medidas de menor abrangência. (p.158).

Assim, a análise das recentes políticas de expansão da educação superior não pode desconsiderar este aspecto destacado por Netto. Por um lado, o incentivo por parte do Estado para o aumento dos níveis de escolarização da população jovem ocorre por pressão de setores financeiros internacionais que consideram a educação como um investimento do Estado para a promoção do desenvolvimento tecnológico e econômico do país. No entanto, ela é também fruto da pressão de grupos e movimentos sociais que encaram a educação superior como estratégia para a superação de condições de desigualdade social. 
Ou seja, as políticas públicas são ações e decisões resultantes das atividades políticas dos governos que sofrem influências diretas dos interesses dos grupos dominantes, mas que também são pautadas pelas demandas apresentadas pela sociedade numa correlação de forças entre projetos e interesses diversos. E, nesse sentido, temos claro que as recentes políticas de expansão da educação superior pública decorrem da necessidade do Estado de articular esses interesses divergentes.

Cabe, ainda, uma ressalva de que as políticas públicas não se materializam somente como ação podendo, em algumas situações, se apresentarem como omissões diante de uma escolha política de determinado governo. E, "essas nãoações geram impactos que, por vezes, podem ser mais dramáticos do que os gerados por ações governamentais" (Pereira, 2008). Quer dizer, a inexistência de políticas sociais para o atendimento de demandas de grupos específicos que requerem, por exemplo, igualdade de condições para o acesso e a permanência no ensino superior público, pode representar a manutenção e reprodução de uma condição de desigualdade social que tem sido característica marcante da sociedade brasileira.

Este enfoque será retomado no capítulo 3 quando abordaremos a questão da assistência estudantil na Universidade Federal do Rio de Janeiro, campo profissional onde a autora deste trabalho atua como assistente social há 25 anos.

Considerando, como ressaltado por Pereira (2008), o caráter contraditório da formulação de políticas sociais, a nova conjuntura política que se inicia no Brasil no final da década de 80 com o processo de abertura política e de redemocratização, promove uma reorganização da esfera pública e no âmbito dos direitos sociais. Os movimentos sociais que atuavam no campo dos direitos e, que durante os anos em que predominou a ditadura política se mantiveram desarticulados, se reorganizaram e passaram a reivindicar a garantia de novos direitos sociais e a criação de políticas sociais mais efetivas, tendo no dizer de Gohn "uma contribuição decisiva, via demandas e pressões organizadas, para a conquista de vários direitos sociais, que foram inscritos em leis na nova Constituição Federal de 1988 (2011, p. 342)

A aprovação da Constituição de 1988, denominada de "Constituição cidadã", é resultado dessa crescente mobilização da sociedade pela ampliação dos direitos sociais. Esse reconhecimento legal representou um avanço em relação à 
sua universalização e à participação da sociedade na definição das políticas sociais que, "como instrumento de materialização dos direitos sociais assume um caráter estratégico de luta social e política para a ampliação da cidadania" (Souza Filho, 1999, p. 116).

A partir desse período há uma retomada do conceito de cidadania tanto nos discursos oficiais quanto nos movimentos populares a partir da expectativa de que a garantia legal dos direitos sociais representava a sua ampliação e efetivação.

No âmbito da educação, os avanços foram em relação à universalização do atendimento escolar pela esfera pública nos níveis fundamentais e médios e o incentivo à expansão da formação superior, não necessariamente pelo setor público.

No entanto, a persistência de elevados índices de desigualdade social, dentre os quais, a desigualdade no acesso à educação superior, reflete que esta condição representa, de fato, uma negação da cidadania. Ou seja, para alguns segmentos da sociedade alguns direitos sociais continuaram não se efetivando a despeito de sua garantia formal.

Em relação à redução das desigualdades sociais, traço marcante da constituição das relações sociais no Brasil, o Estado tem direcionado suas políticas prioritariamente para o aspecto econômico dessa desigualdade. No entanto, a situação de desigualdade social supõe outros determinantes, para além das desigualdades na distribuição da renda, dentre os quais destacamos a educação. A negação do direito à educação, em especial a educação superior, tem sido um dos motivos para que o Brasil conserve e reproduza, ainda nos dias atuais, as desigualdades sociais que o caracterizaram historicamente. Para tentar reverter esse quadro o Estado aprovou recentemente instrumento legal para garantir a implementação de políticas públicas que atendam às necessidades de grupos específicos aos quais tem sido negado o usufruto desse direito.

Netto (2007) embora considerando que o fundamento socioeconômico é a condição primeira para compreender a pobreza e a desigualdade aponta para a diversidade de situações que precisam ser consideradas na análise dessas condições. 
Nas sociedades em que vivemos - formações econômico-sociais fundadas da dominância do modo de produção capitalista - pobreza e desigualdade estão intimamente vinculadas: é condição insuprimível da dinâmica econômica do modo de produção capitalista a exploração de que decorrem a desigualdade e a pobreza. No entanto, os padrões de desigualdade e pobreza não são meras determinações econômicas: relacionam-se, através de mediações extremamente complexas, a determinações de natureza político-cultural; prova-o o fato dos diferentes padrões de desigualdade e pobreza vigentes nas várias formações econômico-sociais capitalistas (Netto, 2007, p.142).

A análise histórica da formação social brasileira tem demonstrado que a concentração de renda leva inevitavelmente à concentração do poder e das decisões políticas e que a manutenção dos padrões de desigualdade em relação à educação escolarizada impede o pleno exercício da cidadania, definindo desse modo, o tipo de democracia existente no Brasil.

\section{Como afirma Pochmann}

O estoque de riqueza e os fluxos de renda no Brasil têm registrado metamorfoses inegáveis desde o período colonial ate os dias de hoje, sem que, todavia deixassem de estar concentrados em apenas um segmento extremamente restrito da população...E ainda, a dimensão e o perfil desta riqueza estiveram relacionados à falta de interesse e compromisso da universalização do acesso à cidadania para amplos segmentos da sociedade brasileira $(2005, \mathrm{p} .26)$

Considerando, conforme apontado por Netto e Pochmann, que o elevado padrão de desigualdade social no Brasil tem determinações diversas a busca de soluções para a redução dessas desigualdades deve se voltar para dois tipos de mecanismos: políticas públicas de combate à pobreza na sua dimensão específica de insuficiência de renda (Henriques, 2000), as denominadas políticas redistributivas, como por exemplo, as políticas de transferência de renda, e as políticas públicas de reconhecimento, destinadas a redução das desigualdades sociais baseadas em aspectos identitários e culturais e que atendam os diferentes grupos nas suas necessidades particulares, como por exemplo, as políticas de ação afirmativa. $^{3}$

\footnotetext{
${ }^{3} \mathrm{O}$ debate sobre as políticas de reconhecimento vem se ampliando no Brasil a partir da implementação das políticas de ação afirmativa, principalmente as que se referem à reserva de vagas para ingresso nas universidades. Para um estudo mais detalhado sobre o assunto, ver SALVADOR, Andréia Clapp - Ação Afirmativa na PUC-Rio: a inserção de alunos pobres e negros. Rio de Janeiro: Ed. PUC-Rio, 2011.
} 
A desigualdade presente em vários campos da vida social e econômica no Brasil impede que parte significativa da população brasileira tenha acesso à condições mínimas de cidadania.

O ensino superior público é um desses campos onde a desigualdade social se torna mais visível já que, historicamente, o acesso a esse nível da formação escolar não esteve destinado a todos as classes sociais. Até recentemente, o número de pessoas de baixa renda e de grupos desiguais que conseguiam ingressar numa universidade pública era pequeno, indicando uma estreita relação entre desigualdade social e educacional.

Paradoxalmente, a expansão do ensino superior e a democratização do acesso a ele tem sido uma das políticas públicas mais incentivadas pelo Estado brasileiro nos últimos 10 anos. No entanto, o alcance das metas do governo para este nível de educação dependerá de outras medidas que viabilizem não somente o acesso, mas que passam necessariamente pela implementação de uma política de permanência do estudante.

Esta política de permanência deve se voltar prioritariamente para o atendimento dos estudantes oriundos dos grupos que vivem em condições de desigualdade de modo que sua trajetória acadêmica não seja dificultada por fatores econômicos e sociais que possam impedir a conclusão de sua formação superior.

A política de expansão do acesso ao ensino superior público que vem sendo implementada no Brasil desde meados dos anos 2000 e a configuração da assistência estudantil na UFRJ dentro desta conjuntura serão analisadas em outra parte deste trabalho.

\section{2.}

\section{Cidadania no Brasil e a Desigualdade no Acesso à Educação}

O conceito de cidadania, que desde sua origem, vem sendo usado para designar os direitos dos cidadãos e indicar a forma de participação dos indivíduos na sociedade tem, ao longo do tempo, se modificado de acordo com as 
transformações sociais e os estágios de desenvolvimento da humanidade. Entretanto, em todos os períodos da história sua definição esteve sempre associada à noção de direitos. Conforme afirma Vianna (2002), introduz-se na cultura política uma concepção de cidadania como "trajetória cumulativa de direitos": direitos civis, direitos políticos e direitos sociais.

No caso do Brasil, em decorrência do modo como se deu a formação da sociedade $^{4}$, essa apropriação dos bens sociais pelo conjunto dos indivíduos da sociedade e o usufruto dos diversos direitos foram determinantes do tipo de cidadania que se constituiu.

Segundo Carvalho (2002)

Houve no Brasil pelo menos duas diferenças importantes. A primeira refere-se à maior ênfase em um dos direitos, o social, em relação aos outros. A segunda refere-se à alteração na sequiência em que os direitos foram adquiridos: entre nós o social precedeu os outros. (p.11-12)

O autor ressalta que a condição de cidadania plena é aquela em que os sujeitos seriam beneficiários dos direitos civis, políticos e sociais. No entanto, esta é uma condição que, na história do Brasil, tem sido alcançada por poucos indivíduos. Embora Carvalho afirme ser a cidadania plena, onde haja liberdade, participação e igualdade para todos um "ideal inatingível”, a mesma tem servido de "parâmetro para o julgamento da qualidade da cidadania em cada país e em cada momento histórico" $(2002$, p.9)

Essas características que distinguiram a formação da cidadania brasileira resultaram que, durante muito tempo alguns direitos civis, políticos e sociais destinavam-se a determinados segmentos da sociedade. No caso dos direitos sociais, embora tenham sido uma conquista da classe trabalhadora (Coutinho, 1997) não se efetivaram da mesma forma para o conjunto da sociedade, tendo sido negados aos que não se encontravam inseridos no mundo do trabalho.

Em relação à construção da cidadania no Brasil Paiva (2010) afirma que devido à desigualdade estrutural da ordem social brasileira não tem se concretizado na modernidade o ideal do "individuo portador de direitos" e a

\footnotetext{
${ }^{4}$ Para um estudo mais detalhado sobre a constituição da cidadania e dos direitos no Brasil, ver José Murillo de Carvalho - A Cidadania no Brasil - o longo caminho, Civilização Brasileira, 2002.
} 
efetivação da condição de cidadão para as pessoas pertencentes aos grupos sociais desiguais. Quer dizer, os princípios da igualdade e da justiça social que fundamentam a concepção dos direitos sociais não estão se realizando e, na prática, ainda ocorre uma sistemática negação do usufruto desses direitos para parcela significativa da sociedade.

A autora apresenta o debate sobre a construção de um novo projeto de cidadania a partir do conceito de identidade e do respeito às "identidades individualizadas" que, juntamente aos direitos universais, vão propiciar uma reorganização da ordem social e a formação de um novo tipo de cidadania:

É essa identidade individualizada que vai pedir seu reconhecimento como legítima participante do espaço público e é esse o caminho para um projeto universalizador de cidadania... o caráter universalizante da cidadania não pode ser tomado como uma pretensão à homogeneidade dos indivíduos que fazem parte do consenso social (Paiva, 2010, p. 21)

Ou seja, essa é uma concepção de cidadania que para sua expressão plena necessita da garantia da igualdade no acesso aos direitos sociais para o conjunto da sociedade preservando-se, no entanto, o reconhecimento das diferenças e das particularidades de cada grupo social.

Como já citado anteriormente, o processo de redemocratização do país, com a aprovação da Constituição de 1988, promoveu uma mobilização social em torno da construção de um novo padrão de cidadania e representou avanços, em especial, para o campo dos direitos sociais. Nesse processo de construção, os sujeitos sociais começam a questionar os padrões de desigualdade social, marca predominante da constituição da sociedade brasileira e o tratamento desigual dado as pessoas de acordo com sua origem de classe social, sua raça, sua etnia ou seu gênero. A mobilização da sociedade teve reflexos tanto na ampliação da abrangência das políticas sociais, com a universalização de alguns direitos, como também na inclusão de questões relativas aos direitos das "minorias" cujas demandas são reconhecidas como legitimas e que serão foco, a partir da década de 90, das reivindicações de alguns movimentos sociais pela criação de políticas específicas.

O processo de abertura política do final dos anos 80 possibilitou a reorganização de movimentos sociais de setores da população que viviam 
historicamente em condições de discriminação e desigualdade, como a situação da população negra e dos índios. Esses grupos passaram a reivindicar a ocupação de espaços dos quais sempre estiveram alijados, como a universidade, por exemplo.

Dentro dessa nova concepção da cidadania, os movimentos sociais organizados buscavam tanto o direito à igualdade no usufruto de direitos socialmente produzidos, condição esta oposta à de desigualdade, como também o direito a terem assegurado o respeito às suas diferenças e especificidades, princípio que será a base de sustentação da implementação das políticas de ação afirmativa. ${ }^{5}$

Nas sociedades capitalistas a promessa de igualdade entre os indivíduos fica restrita meramente aos aspectos legais já que relações de exploração e dominação são características marcantes dessas formas de organização social. No contexto do capitalismo, é ingenuidade pensar na eliminação das desigualdades já que sua existência é a base de sustentação das sociedades capitalistas.

Dentre os direitos sociais, a educação é o que, reconhecidamente, tem papel fundamental para a construção de um padrão de cidadania pautado numa maior igualdade social. Este fato é destacado por Carvalho (2002) ao afirmar que a única exceção admitida por Marshall na seqüência de constituição dos direitos refere-se à educação, por considerá-la pré-requisito para a expansão dos direitos civis e políticos:

\begin{abstract}
Nos países em que a cidadania se desenvolveu com mais rapidez, por uma razão ou outra, a educação popular foi introduzida. Foi ela que permitiu às pessoas tomarem conhecimento de seus direitos e se organizarem para lutar por eles. A ausência de uma população educada tem sido sempre um dos principais obstáculos à construção da cidadania civil e política (2002, p.11)
\end{abstract}

$\mathrm{Na}$ história brasileira, o acesso à educação esteve restrito durante muito tempo aos grupos sociais economicamente mais favorecidos e funcionou sempre como instrumento de reprodução das relações sociais desiguais.

Embora presente nas várias constituições brasileiras desde a década de 30, sendo alvo de variadas legislações e regulamentações que definiram o padrão educacional brasileiro, foi com a Constituição de 1988 que a educação é

\footnotetext{
${ }^{5}$ MOEHLECKE, Sabrina (2002) realiza um estudo detalhado sobre o tema das ações afirmativas apresentando varias definições e conceituações para o termo cuja ideia central é a de "restituição de uma igualdade que foi rompida ou que nunca existiu" (p. 200)
} 
reconhecida como um "Direito de todos e dever do Estado e da família...visando ao pleno desenvolvimento da pessoa, seu preparo para o exercício da cidadania e sua qualificação para o trabalho" (Art. 205 da Constituição de 1988). Este é o momento em que a educação é reconhecida como direito social e ganha novo status dentro da concepção de universalização dos direitos e da consolidação da democracia e da cidadania.

Em relação à educação superior que se estabeleceu no Brasil tardiamente ${ }^{6}$ o que se constata é que houve, desde sua origem, um acesso e usufruto diferenciado desse direito que era condicionado por fatores tais como o pertencimento a uma classe social, raça ou gênero. E, embora a Constituição de 1988 estabeleça no seu artigo 206 o princípio da igualdade de condições para o acesso e permanência na escola, para as pessoas oriundas das classes populares e dos grupos desiguais essa é uma realidade que está muito longe de se concretizar em quaisquer dos níveis educacionais.

A situação de carência socioeconômica familiar, por exemplo, pode interferir no processo de aprendizagem e na conclusão até mesmo dos níveis fundamentais da educação, já que muitos jovens pobres acabam abandonando a escola para ingressar no mundo do trabalho informal.

Embora do ponto de vista legal e jurídico tenha havido uma ampliação da abrangência das políticas sociais e da universalização de alguns direitos, a realidade política e estrutural da modernidade impediu a sua concretização e, na prática, a igualdade não se verifica no cotidiano de diferentes grupos. $\mathrm{O}$ acesso à educação e, em especial à educação superior pública, continuou restrito a grupos específicos de pessoas pertencentes às classes dominantes num processo de reprodução das condições de desigualdade, traço já marcante da realidade brasileira.

O cenário de debates e de aprovações de leis para a garantia de direitos sociais que são formuladas a partir da Constituição de 88 chama atenção para a questão da desigualdade no acesso à educação superior.

\footnotetext{
${ }^{6}$ Segundo Oliveira (2011) foi somente em 1808 com a chegada da família real ao Brasil que se acentua a necessidade de formação de pessoal com estudos superiores que se encarregasse da defesa, obras públicas, saúde, etc., sendo os primeiros cursos criados os de medicina e de engenharia, organizados em escolas isoladas. Ver OLIVEIRA, A.J. A Casa de Minerva: entre a ilha e o palácio. O discurso sobre os lugares como metáfora da identidade institucional. Tese Doutoramento apresentada ao Programa de Pós Graduação em Memória Social, Universidade Federal do Estado do Rio de Janeiro, 2011.
} 
Esse fato, aliado à necessidade de adequação do sistema educacional brasileiro às exigências da ideologia neoliberal que, a partir dos anos 90 terá uma maior influência na implementação das políticas sociais, vão ter como resultado o incremento nas políticas de democratização do acesso implementadas pelo Estado a partir do final dos anos 90 e que tiveram continuidade nos anos seguintes ${ }^{7}$.

Dentre os instrumentos legais que deram início à reforma do sistema educacional a partir da Constituição de 88 tem-se a Lei de Diretrizes e Bases LDB de 1996 e o Plano Nacional de Educação de 2001, que previam dentre outras ações, a reorganização da educação superior.

No entanto, logo se verificou que o problema da desigualdade na educação não se restringia às políticas de acesso às universidades, ficando evidente que não bastava garantir a democratização do ingresso de estudantes no ensino superior sem oferecer condições para a permanência. Desse modo a questão da permanência passa a ser vista como uma das condições primordiais para a efetivação do direito à educação superior e a formulação de uma política de assistência ampliada, pauta de reivindicação de setores das universidades e da sociedade civil.

No $2^{\circ}$. capítulo deste trabalho será abordado o tema da assistência estudantil e as iniciativas por parte do Estado de criação de medidas que tem favorecido que a mesma venha a se consolidar como política social de permanência do estudante, mecanismo fundamental para a efetivação do direito à educação.

Embora reconhecendo que alguns aspectos da cidadania podem ser exercidos mesmo pelos que não tiveram acesso à educação, somos instados a concordar com Carvalho (2002) e Paiva (2010) que atribuem à educação um papel fundamental na forma como essa cidadania é exercida e afirmam que, o alcance de uma sociedade democrática com menores índices de desigualdade passa, necessariamente, pela educação.

Nos últimos anos tem ficado cada vez mais clara a percepção da influência da educação no desenvolvimento econômico do país, principalmente numa conjuntura política dominada pela ideologia neoliberal.

\footnotetext{
${ }^{7}$ A questão das políticas de democratização do acesso ao ensino superior será retomada em outro capítulo deste trabalho.
} 
Entretanto, a educação, em especial, a educação superior não se destina apenas aos interesses dos setores dominantes da sociedade. A educação gera possibilidades de mobilidade social e melhorias financeiras para as pessoas das classes mais desfavorecidas, o que médio e longo prazo exerce impacto na diminuição da desigualdade social.

A educação formal pode, ainda, contribuir para que pessoas dos grupos desiguais façam parte da construção de um novo projeto de sociedade, mais diverso e com menores índices de desigualdade, onde a presença desses sujeitos não seja motivo de estranhamento, violência e exclusão. ${ }^{8}$

Tomando por referência a afirmação de Carvalho (2002), segundo o qual "a ausência de uma população educada tem sido sempre um dos principais obstáculos à construção da cidadania civil e política" (p.11) vemos que a organização e distribuição da educação têm relação direta com a organização da sociedade e com a sua formação histórica.

A existência de uma população com pouca escolaridade é condição primária para a manutenção de uma sociedade onde predominam as relações de dominação de classe e onde alguns grupos sociais têm mais privilégios e mais direitos do que outros no acesso aos bens sociais. O direito à educação amplia as oportunidades sociais, econômicas e políticas possibilitando o rompimento com um padrão de desigualdade social que alcança na atualidade níveis excessivamente elevados. Para os grupos sociais que sofrem discriminações de renda, raça, gênero ou outras, as possibilidades de mudança da estrutura social desigual brasileira passam pela educação por sua vinculação com a ampliação da cidadania e dos direitos sociais.

Neste sentido, as políticas educacionais historicamente implementadas no Brasil, têm se constituído muito mais como um instrumento de diferenciação social do que uma possibilidade concreta de construção e ampliação da cidadania, não se efetivando para a população de forma geral como um direito social que deve "igualar situações sociais desiguais" (Bobbio, 1992, p.32-33)

\footnotetext{
${ }^{8}$ O tema da exclusão social não será abordado neste trabalho. Apenas faço referência a ele por ser esta uma condição que atinge com grande violência um grande número de pessoas nas sociedades modernas com vinculação direta à condição de pobreza e de desigualdade. Para um estudo detalhado do tema, ver ESCOREL, Sarah - Vidas ao Léu - Trajetórias de Exclusão Social, Rio de Janeiro, Ed. Fiocruz, 1999.
} 
Em relação à condição de igualdade, Benevides (2008) afirma que os direitos civis e políticos são condições para a liberdade enquanto os direitos sociais são os que vão garantir a redução das desigualdades de origem, aquelas que se definem pelo pertencimento a uma determinada classe social e pela ausência do acesso a bens e serviços. Na ausência desses direitos sociais não se tem o principio da igualdade.

Ou seja, não basta criar condições de igualdade para o acesso à universidade se no seu interior permanecerem condições desfavoráveis, desiguais e invibilizantes para a permanência dos estudantes. A existência de programas de apoio socioeconômico e pedagógico para os estudantes em condições de desigualdade financeira e de escolaridade deve fazer parte do processo de ampliação das universidades. Na ausência desses programas, a expectativa de expansão e democratização do ensino superior, alvo das recentes políticas públicas educacionais, tenderá ao fracasso.

A igualdade proposta na cidadania democrática não se caracteriza, segundo Benevides (ibidem), pela uniformidade de todos os seres humanos, uma vez que o contrário da igualdade não é a diferença, mas a desigualdade que é socialmente construída, principalmente nas sociedades capitalistas. Desta forma, as políticas educacionais devem ser complementadas por ações voltadas para o atendimento das especificidades de determinados grupos sociais que se encontram em condições de desigualdade, a fim de que se efetive a igualdade formalmente constituída.

Com já afirmado anteriormente, o princípio inerente aos direitos sociais é o da igualdade e da justiça social. No entanto, o contexto ideológico e político do Brasil tem se mostrado, ainda nos dias atuais, insuficiente no campo da igualdade no acesso a bens sociais, a despeito da Constituição cidadã e do investimento feito pelo Estado, nos últimos anos, para o incremento de políticas sociais de combate à pobreza.

Apesar da efetiva redução da pobreza verificada nas pesquisas oficiais nos últimos anos, paradoxalmente os índices de desigualdade social e econômica se intensificaram. Para Sposati (2011) as políticas sociais focalizadas, que não alcançam as necessidades sociais universais acabam por contribuir para a reprodução da desigualdade entre os cidadãos no usufruto dos direitos sociais gerando "a conversão das políticas sociais de direitos em políticas sociais de 
combate à pobreza, que se voltam para a redução da pobreza, sem alcance de direitos sociais"

O padrão de concentração de riqueza característico da formação da sociedade brasileira manteve-se inalterado até os dias de hoje, havendo uma redução da pobreza absoluta sem que isto, no entanto, esteja associado à diminuição da pobreza relativa, vinculada a desigualdade (Pochmann, 2005).

Analisando esse fenômeno Salvador (2011) afirma:

O mundo contemporâneo tem sido caracterizado como a era das desigualdades, atribuídas principalmente à política neoliberal que se consolida tanto nos países centrais quanto nos periféricos. Entretanto, a desigualdade seja ela de cunho social, econômico ou racial, é uma realidade já antiga que vem se perpetuando ou se acentuando ao longo dos tempos (2011, p.19)

Talvez o fato mais alarmante dessa questão seja que a desigualdade é aceita como algo normal e natural por parte dos diversos grupos sociais que convivem na sociedade brasileira ainda que, no dizer da autora, essa seja uma "coexistência relativamente pacífica" já que, as relações sociais entre estes grupos, nem sempre ocorrem de forma cordial e harmoniosa e os acordos e pactos que são estabelecidos podem se alterar ou modificar de acordo com a dinâmica da realidade social.

Quer dizer, os sujeitos organizados em movimentos sociais têm questionado esta condição de desigualdade e reivindicado a sua inserção em espaços onde sempre estiveram excluídos. As manifestações e reivindicações de grupos sociais excluídos dos vários direitos sociais, como por exemplo, o movimento negro, que elegeu o tema da educação para questionar o padrão de cidadania no Brasil, trouxeram à tona o tema da desigualdade contribuindo para desnaturalizar relações sociais desiguais. As ações propostas por estes grupos visam promover alterações e fraturas nessa rígida estrutura societária num processo de reversão de um quadro que se encontra historicamente estabelecido.

Para a obtenção de uma igualdade não apenas formal, mas que efetivamente promova a redução das desigualdades sociais são necessárias ações e intervenções de diferentes níveis que possibilitem respostas concretas a um problema, a desigualdade social, que tem determinantes diversos. 
Dentre as ações e estratégias que surgem como alternativas para a redução das desigualdades sociais Salvador (ibidem) apresenta aquelas que passam por garantir o acesso à educação para um grupo social que, embora seja parte majoritária da população brasileira, historicamente tem sido excluído desse direito. ${ }^{9}$ A autora faz referência, em especial às políticas de ação afirmativa para ingresso na educação superior destinadas à população negra, chamada usualmente de "cota racial".

As políticas de ação afirmativa e demais políticas públicas destinadas à expansão e democratização da educação superior, são referências importantes para a ampliação do usufruto de direitos sociais e como estratégia de combate às desigualdades sociais.

Ou seja, as políticas de ação afirmativa são mecanismos para a efetivação da igualdade no acesso aos direitos sociais que já se encontram garantidos legalmente.

Ainda no que se refere à possibilidade de conciliação entre a obtenção da cidadania a partir da Constituição de 1988 com a herança de desigualdade característica da formação social brasileira, também Paiva (2010) afirma que o ideal republicano de igualdade e concretização de direitos que a Constituição de 1988 anunciava, vem se mostrando difícil de realizar diante do agravamento do quadro de desigualdades sociais no Brasil.

As universidades públicas, espaços tradicionalmente voltados às classes dominantes vem se deparando, nos últimos anos, com uma mudança no perfil de seus estudantes. Este fato deve-se, principalmente à implementação das políticas de democratização do acesso, dentre estas as políticas de ação afirmativa, em especial as que reservam percentual das vagas para o ingresso de pessoas pertencentes aos grupos sociais desiguais como os negros, indígenas e pessoas oriundas da rede pública de educação.

\footnotetext{
9 A autora apresenta a discussão sobre Políticas de Ação Afirmativa, em especial aquelas conhecidas como "cotas" voltadas para a população pobre e negra brasileira. Sua argumentação tem como fundamento o estudo desenvolvido por Nancy Fraser que apresenta a tese de que a justiça social deve ser implementada a partir da constituição de dois tipos de políticas: políticas redistributivas (voltadas à redistribuição de renda e reorganização da divisão do trabalho) e políticas de reconhecimento (voltadas para a valorização de identidades desrespeitadas para redução das desigualdades sociais baseadas em aspectos identitários e culturais).
} 
A expectativa que se coloca é de que a presença cada vez maior de pessoas oriundas dos grupos populares num espaço que tem como característica ser elitista e excludente possa provocar rupturas numa ordem social marcadamente desigual.

No entanto, para os estudantes oriundos das classes populares o direito à educação superior não irá se efetivar apenas com as políticas destinadas ao acesso à universidade já que o problema da seletividade social na educação superior vai além da inexistência de vagas ou das formas de seleção para o ingresso. Para esse grupo de estudantes que vem, em geral, de famílias pobres e com formação escolar deficitária, a inexistência de programas de apoio financeiro e pedagógico, entre outros, pode representar obstáculos à sua trajetória acadêmica e à vivência integral da experiência universitária, conformando um processo contraditório de inclusão/ exclusão.

No caso da UFRJ, por exemplo, a ausência de programas de apoio pedagógico aos alunos oriundos das classes populares, por exemplo, pode levá-los a abandonar os cursos, a despeito da recém-adoção de reserva de vagas para estudantes oriundos de escolas públicas. Do mesmo modo, o não atendimento às demandas de saúde, em especial na questão do suporte psicológico, pode contribuir para que um segmento de estudantes tenha uma vivência acadêmica conturbada e/ou desistência da formação superior já que ao ingressar num espaço social do qual sempre esteve alijado, por vezes precisa lidar com situações de discriminação, preconceito e exclusão.

Enquanto uma política social, a assistência estudantil destina-se a promover igualdade de oportunidades aos estudantes de grupos desiguais como os oriundos das classes populares, os negros, os indígenas, os deficientes físicos, etc. que estão tendo acesso à educação superior, numa perspectiva de expansão dos direitos sociais e de ampliação da cidadania.

Como apontado por Netto (2007), Pochmann (2005) e Henriques (2000) a redução dos níveis de desigualdade social no Brasil não depende apenas de programas voltados para o atendimento das dimensões econômicas mais imediatas, que, embora fundamentais para a sobrevivência em seus níveis mais elementares, não são suficientes para uma efetiva alteração da organização social brasileira. Corroborando com os autores citados, as possibilidades de mudança passam, a meu ver, pela existência de políticas e programas que, aliadas aquelas que visam à redução da pobreza e uma melhor distribuição da renda, atinjam 
também outros campos onde a desigualdade, sejam elas econômicas, de gênero ou de raça permanecem.

Nos últimos anos, tem-se observado indícios de alteração no quadro de desigualdade na educação superior com relação à composição social e racial dos estudantes das universidades públicas. Na pesquisa sobre o Perfil Socioeconômico e Cultural dos Estudantes de Graduação das Universidades Federais Brasileiras, realizada em 2010 pelo Fórum Nacional de Pró-Reitores de Assuntos Comunitários e Estudantis - FONAPRACE ${ }^{10}$ foi verificado um aumento do número de pessoas dos grupos desiguais que ingressam na educação superior. Esta alteração é mais visível nas universidades que promoveram esse processo de democratização do acesso e a implementação de políticas de ação afirmativa há mais tempo. Dentre estas destacamos: a Universidade Federal da Bahia/UFBA, a Universidade de Brasília/UNB e a Universidade Federal do ABC/UFABC. Cabe ressaltar que, esse não foi o caso da UFRJ que, apenas em 2010, adotou o sistema de reserva de vagas para ingresso em seus cursos de graduação para estudantes oriundos da rede pública de educação. E somente no concurso de acesso para o ano de 2013, após a aprovação da Lei 12.711 de 29 de agosto de 2012 que dispõe sobre o ingresso nas universidades federais, incluiu o critério racial associado ao de origem da escola. Tal fato é um indicativo de que permanece forte a resistência por parte dos que vêem com desconfiança a presença de pessoas dos grupos desiguais e que desejam que a UFRJ continue sendo um espaço voltado para as elites.

O termo desigual significa um processo relativo a tramas sociais quanto à posse e distribuição de bens socialmente produzidos. A desigualdade social não é algo natural, mas resultado do processo histórico e das decisões políticas da correlação de forças presente na sociedade. Ninguém é menos inteligente por ser pobre ou negro, mas as questões raciais e de classe social presente em nossa sociedade acabam por distribuir os bens materiais e simbólicos de forma a criar situações que não oportunizam as mesmas chances para todos.

As dificuldades e obstáculos para o acesso e a permanência de pessoas pertencentes aos grupos populares à educação escolarizada em seus diversos níveis e, em particular, em seus níveis mais elevados, funcionam como

\footnotetext{
${ }^{10}$ Para ver o relatório da pesquisa consultar www.andifes.org.br.
} 
mecanismos de exclusão e de reprodução da desigualdade social. A manutenção das condições de desigualdade de classe, de raça e de gênero contribui para o aprofundamento do projeto político neoliberal e representa um retrocesso no processo de construção democrática e de ampliação da concepção de cidadania que teve início no Brasil com a Constituição de 88.

$\mathrm{Na}$ análise de Dagnino (2004) trata-se de uma redefinição da noção de cidadania:

Um dos elementos constitutivos dessa concepção de cidadania se refere à noção mesma de direitos, cujo ponto de partida é a concepção do direito a ter direitos, que não se limita a provisões legais, ao acesso a direitos definidos previamente ou à efetiva implementação de direitos formais abstratos. Ela inclui a invenção/criação de novos direitos que surgem de lutas especificas e de suas práticas concretas.... Além disso, essa redefinição inclui não somente o direito à igualdade, como também o direito à diferença, que especifica, aprofunda e amplia o direito à igualdade. (2004, p.104)

Desse modo, as conquistas e avanços na área dos direitos sociais, incluindo os que promoveram a expansão da educação superior para os grupos desiguais, não devem ser considerados pequenos, dada a forma como historicamente se constituiu a cidadania no país. A discussão sobre questões como desigualdade, direitos específicos para grupos historicamente excluídos, políticas públicas que visem tanto à igualdade quanto as diferenças, contribuiu para uma nova perspectiva de cidadania, não mais como privilégio de alguns, mas como uma proposta de nova forma de organização da sociedade.

\section{3.}

\section{As Políticas para a Educação Superior no Brasil: algumas considerações}

Num breve histórico da gênese da educação superior no Brasil recorremos a diversos estudos que apontam que seu surgimento se deu de forma tardia em 
relação aos demais países da América e da Europa. ${ }^{11}$ Embora tenham ocorrido tentativas de criação de universidades brasileiras durante os primeiros anos do século XX, foi somente em 1920 que a primeira universidade pública federal do Brasil é oficialmente criada, intitulada Universidade do Rio de Janeiro, posteriormente renomeada para Universidade do Brasil (1937) e Universidade Federal do Rio de Janeiro (1965). ${ }^{12}$

No caso da UFRJ, campo empírico deste trabalho, estudos apontam que, pelo modo como seu deu a sua formação, com a reunião de escolas, faculdades e institutos isolados, suas principais características foram a fragmentação, o isolamento e a elitização. Como afirma Oliveira (2012) a UFRJ "conhecida, nacionalmente, pela sua longevidade, excelência e tamanho foi também marcada por um elitismo que se apresentava já em suas origens, ainda como Universidade do Brasil: uma universidade das elites para a formação de elites."

No entanto, esta característica de elitização não é uma realidade exclusiva da UFRJ, mas também das demais universidades públicas onde predominou até bem recentemente a seletividade do grupo social a que se destina a formação superior, como também toda a formação escolar até meados do século XX.

Para Wanderley (2003)

A Universidade é a instituição social que forma, de maneira sistemática e organizada, os profissionais, técnicos e intelectuais de nível superior que as sociedades precisam. Situa-se na esfera da superestrutura, dentro da sociedade civil, mantendo vínculos com a sociedade política e a base econômica. Serve normalmente à manutenção do sistema dominante, mas pode também servir à transformação social (2003. p.11).

Ou seja, as universidades públicas brasileiras se constituíram e consolidaram como um sistema fragmentado, de caráter profissionalizante, voltado prioritariamente para a formação das elites do país, mas que também pode contribuir para a formação de indivíduos comprometidos com outro projeto de

\footnotetext{
${ }^{11}$ Para um estudo mais detalhado sobre a história da educação superior no Brasil, ver ARANHA (1996), CUNHA (1980), FÁVERO (2010) e OLIVEIRA, A.J. (2011)

12 Alguns estudos consideram que a primeira universidade pública criada no Brasil foi a Universidade Federal do Amazonas (UFAM) em 1909.
} 
sociedade embora o seu papel social venha sofrendo significativas alterações desde meados do século XX. ${ }^{13}$

A evolução da educação superior no Brasil seguiu uma tendência bastante diferenciada dos demais países da América Latina, com uma expansão de universidades públicas entre os anos de 1930 e 1970 e, posteriormente, o que se verificou foi uma desresponsabilização do Estado pelo atendimento da demanda crescente pela formação superior com a transferência dessa responsabilidade para o setor privado. A expansão da educação pela via do setor privado se deu num crescente desde os anos 80 até meados dos anos 2000, chegando a ter no ano de 2007 74,5 \% das matrículas em instituições privadas de ensino superior segundo dados do Instituto Nacional de Estudos e Pesquisas Anísio Teixeira (INEP/MEC 2009).

Motivada por fatores diversos e, por vezes, contraditórios a educação superior passar a ser uma das áreas sociais mais importantes e um dos principais focos de atenção das políticas governamentais a partir do final dos anos 80 para a concretização do desenvolvimento do Estado brasileiro e para o atendimento ao sistema de produção internacional.

Há uma alteração dos paradigmas para a sua formulação e implementação e o incentivo à sua expansão se expressa nos vários planos e metas de elevação dos níveis de escolaridade da população para atendimento as exigências da modernidade.

A nova configuração da sociedade implica na necessidade de ampliação dos níveis de escolaridade da população para atendimento às novas exigências do capital ainda que o novo paradigma educacional esteja orientado "predominantemente pela racionalidade do capital, conduzindo a uma inequívoca

\footnotetext{
${ }^{13}$ Marilena Chaú ao falar sobre a mudança do papel social da universidade decorrente da Reforma do Estado que vem sendo promovida desde o final da década de 80 do século XX, afirma que a designação da universidade pública como organização social com a finalidade de prestar serviço ao Estado e não mais como instituição social, que realiza e exprime a sociedade de que faz parte, com suas contradições e possibilidades, demonstra uma clara substituição do conceito de direitos pela concepção de serviços. Para Chaú, a definição da universidade enquanto instituição social tem sua fundamentação na universalidade e os valores da sociedade como princípio e referência. Contrariamente, ao ser definida como organização, tem a si mesma como referência e seu sucesso e eficácia se medem em termos da gestão de recursos e estratégias de desempenho para obtenção de objetivos particulares que a definem. Em suma, a universidade passa a ser uma "organização prestadora de serviços". Marilena Chauí, Escritos sobre a Universidade. São Paulo. Editora UNESP, 2001.
} 
subsunção da esfera educacional à esfera econômica, num processo denominado de mercantilizarão da educação superior" (Reis, 2001, p.259).

Ou seja, a reforma educacional, como as demais políticas sociais na década de 90 deveriam ser estabelecidas não mais pelas demandas sociais e sim pelas determinações econômicas, em consonância com as orientações dos organismos financeiros internacionais.

No entanto, não se pode deixar de destacar as pressões de segmentos dos movimentos sociais que reivindicavam o acesso à educação superior, vendo no usufruto desse direito uma possibilidade de alterações na estrutura social desigual que predomina no Brasil.

Embora não seja nossa intenção realizar neste trabalho uma análise da atuação dos movimentos sociais, não podemos deixar de destacar que a mobilização expressiva de setores organizados da sociedade civil contribuiu para o fato da educação ser, no Brasil, o direito social que teve por parte do Estado a maior quantidade de regulamentação no decorrer do século XX e início do século XXI, com as chamadas reformas educacionais. ${ }^{14}$.

Ou seja, a ampliação do acesso à educação não tem por finalidade apenas atender as necessidades de formação demandadas pela exacerbação da financeirização do capitalismo e pelos organismos financeiros internacionais. A educação tem um papel central como mecanismo de alteração das condições de desigualdades sociais e econômicas e enquanto um direito social deve estar acessível a todos os grupos sociais, independentes de sua origem de classe, de sua raça ou etnia.

Dados do PNAD (2009) indicam que durante toda a década de 90 houve um crescimento do número de jovens que estão frequentando e concluindo o nível fundamental de ensino. Em relação ao nível secundário, embora também tenha ocorrido um crescimento no número dos jovens que ingressaram nesse segmento da educação, continuou muito elevado o número de alunos que não completaram a formação.

Quanto ao ensino superior, embora seja considerado como um direito social desde a promulgação da Constituição de 1988, apenas 19\% dos jovens entre 18 e 24 anos (PNAD, 2009) está na universidade.

\footnotetext{
${ }^{14}$ Apenas fazemos referência ao protagonismo dos diversos movimentos sociais na luta pelo direito à educação sem pretender aprofundar, neste estudo, a discussão sobre a temática
} 
A tabela abaixo demonstra que o acesso a este nível de escolaridade ainda é uma realidade muito distante para uma grande parcela da população pertencente às classes mais desfavorecidas economicamente.

Tabela 1- Percentual de jovens com idade de 18 a 24 anos segundo a renda familiar e o acesso à educação. Brasil, 2009

\begin{tabular}{|l|r|r|r|r|r|r|}
\hline Nível de escolaridade & Quintil 1* & Quintil 2 & Quintil 3 & Quintil 4 & Quintil 5 & \multicolumn{1}{c|}{ Total } \\
\hline $\begin{array}{l}\text { Não completou Ensino } \\
\text { Fundamental (freq ou não } \\
\text { freq) }\end{array}$ & $44 \%$ & $26 \%$ & $15 \%$ & $7 \%$ & $3 \%$ & $21 \%$ \\
\hline $\begin{array}{l}\text { Não conclui o ensino } \\
\text { médio (freq ou não freq) }\end{array}$ & $33 \%$ & $34 \%$ & $29 \%$ & $21 \%$ & $12 \%$ & $27 \%$ \\
\hline Completou ensino médio & $21 \%$ & $33 \%$ & $42 \%$ & $43 \%$ & $26 \%$ & $33 \%$ \\
\hline $\begin{array}{l}\text { Teve acesso ao ensino } \\
\text { superior }\end{array}$ & $3 \%$ & $7 \%$ & $14 \%$ & $29 \%$ & $60 \%$ & $19 \%$ \\
\hline Total & $100 \%$ & $100 \%$ & $100 \%$ & $100 \%$ & $100 \%$ & $100 \%$ \\
\hline
\end{tabular}

* Quintil 1 - equivale às pessoas mais pobres / Quintil 5 - equivale às pessoas mais ricas Fonte: Dados do PNAD/IBGE, 2009.

Como estratégia para reverter o quadro precário do nível educacional brasileiro, o Estado promove a partir dos anos 90 várias reformas da política educacional havendo um grande incentivo à expansão do acesso à educação superior ainda que, essa ampliação, seja prioritariamente pela via do setor privado como verificado nos dois governos FHC e nos primeiros anos do governo Lula.

As reformas educacionais implementadas no governo FHC tiveram como foco as ações direcionadas à privatização do ensino superior, na perspectiva da ideologia neoliberal de "formação da população brasileira em processos cognitivos, nos necessários conteúdos postos pela mundialização do capital, tornando cada cidadão apto para o trabalho" (Silva Junior, 2005).

Essa política educacional representou uma opção do Estado pelos interesses dos setores privados e levou a uma total retração dos investimentos na educação superior pública, com a quase falência das universidades federais e com reflexos diretos sobre os recursos destinados às questões sociais, dentre as quais a assistência estudantil. O corte de verbas levou à extinção de alguns programas de apoio à permanência como o pagamento de bolsas de apoio financeiro bem como à ausência de investimentos para as obras de manutenção das moradias estudantis 
existentes, diminuição no número de bolsas acadêmicas, medidas estas tomadas em consonância com as orientações dos órgãos internacionais.

Dentre as recomendações do Banco Mundial para a educação superior contidas no documento intitulado "La enseñanza superior: las leciones derivadas de la experiência") constava a de "eliminação de gastos com políticas compensatórias (moradia, alimentação)“ (Dourado, 2002) o que representou na prática a quase total inexistência de programas de assistência estudantil nas IFES - Instituições Federais de Educação Superior.

No caso da Universidade Federal do Rio de Janeiro- UFRJ, campo de pesquisa do presente trabalho, este quadro levou ao desmonte de alguns dos principais programas de assistência estudantil, como o fechamento dos restaurantes universitários, o cancelamento de programas de bolsas assistenciais (bolsa de estudos) e acadêmicas (monitoria) e os poucos programas que permaneceram dependiam de recursos gerados pela própria universidade.

As reformas educacionais vão ter continuidade no governo Lula que se inicia no ano de 2003. No entanto, as diretrizes desse novo governo para a educação são no sentido de promover uma política que articulasse os interesses e pressões dos diversos setores envolvidos: sociedade civil e movimentos sociais, setores educacionais públicos e privados e organismos financeiros internacionais e que refletisse o cumprimento do compromisso com políticas de inclusão social presente nos discursos de campanha e que contribuíram para sua vitória no processo eleitoral.

No caso da expansão da educação superior, as principais medidas incentivadas vão se dar, inicialmente, pela via do setor privado com a criação do Programa Universidade para Todos - PROUNI e do Programa de Financiamento Estudantil - FIES.

Em relação ao setor público as principais medidas neste sentido são a implementação em 2007 do Programa de Reestruturação e Expansão das Universidades Federais - REUNI e a retomada da discussão sobre as políticas de ação afirmativa, em especial a reserva de vagas, com vistas à sua transformação em lei. ${ }^{15}$

\footnotetext{
${ }^{15}$ Após muitos anos de debates em torno da questão, foi aprovada em 29 de agosto de 2012 a Lei 12.711 que Dispõe sobre o ingresso nas universidades federais e nas instituições federais de ensino
} 
A partir desse período verifica-se um estímulo ao crescimento das vagas nas universidades públicas, que tem uma expressiva expansão no número de matrículas entre os anos de 2001 a 2010.

Dados do Censo da Educação Superior de 2010, elaborado pelo Instituto Nacional de Estudos e Pesquisas - INEP e que analisa o período compreendido entre os anos de 2001 a 2010, demonstram que o total de matrículas em cursos de graduação no ano de 2010 representa mais que o dobro das matrículas de 2001 . O relatório salienta que, embora essa expansão tenha se dado preponderantemente no setor privado, houve certa estabilização da participação desse setor a partir de 2008. Em relação ao setor público, o relatório aponta um crescimento de $85 \%$ no número de matrículas nas IFES no mesmo período, com um maior crescimento a partir de 2008, ficando, ainda assim, muito abaixo dos números do setor privado.

O crescimento das matrículas no setor público é decorrência direta do Programa de Reestruturação e Expansão das Universidades - REUNI instituído pelo decreto 6.096 de 24 de abril de 2007 como uma das ações do Plano de Desenvolvimento da Educação - PDE de 2007 que "pretende congregar esforços para a consolidação de uma política educacional de expansão da educação superior pública" (Brasil - MEC - REUNI)

Partindo da premissa de ampliação do acesso com a garantia de manutenção da qualidade da graduação o REUNI tem por objetivo, "criar condições para ampliar o acesso e a permanência na educação superior a partir de um melhor aproveitamento da estrutura física e de recursos humanos existentes nas universidades federais" (Art. $1^{\circ}$. Decreto 6.096, de 24 de abril de 2007).

O REUNI surge também como uma resposta do governo federal às críticas pela forma como o setor privado de educação superior vinha sendo privilegiado na concessão de recursos financeiros durante toda a década de 90 e início dos anos 2000. E, embora preconize o respeito à autonomia universitária e às características de cada instituição, vem sendo alvo de reações contrárias por parte do movimento docente e do movimento estudantil pela forma precária com que está se dando a expansão e a interiorização.

As principais críticas referem-se à reconfiguração do papel das universidades públicas federais, que seriam reduzidas a instituições de ensino de 
graduação para a promoção da "certificação em larga escala" e à intensificação do trabalho docente para atendimento às metas de elevação do número de estudantes de graduação.

Analisando a reformulação da educação superior Lima (2012) aponta que o REUNI, embora tenha expandido de fato o acesso à educação superior, é uma das várias ações que vem sendo implementada para viabilizar uma "terceira fase da expansão da educação superior nos marcos de um neoliberalismo reformado" (p. 14)

Ressalte-se que, apesar do incentivo representado pelo REUNI para a expansão da educação superior no setor público, o Estado continuou transferindo recursos para o setor privado através do FIES $^{16}$ e investindo em programas de inclusão no ensino superior privado via o Programa Universidade para Todos PROUNI, que dá isenção fiscal às universidades que aderirem ao programa.

Embora a criação desses programas demonstre a intenção do Estado em desenvolver políticas de inclusão social temos claro que, em última instância, essas medidas fazem parte de um conjunto maior de ações para implementação da Reforma do Estado, diante das exigências de reestruturação produtiva imposta por organismos financeiros internacionais.

Em relação às essas políticas de inclusão Pereira e Silva (2010) fazem a seguinte reflexão:

\begin{abstract}
Nesse cenário, a análise das políticas públicas para o ensino superior no Governo Lula permite afirmar que o crescimento do acesso impõe desafios qualitativos e de inclusão aos gestores e demais profissionais das instituições de ensino superior. Cabe, na medida em que diferentes políticas foram criadas e desenvolvidas, pensar formas de inclusão que contemplem segmentos da sociedade historicamente excluídos do ensino universitário, como, por exemplo, as classes populares, os afro-descendentes e os indígenas. Ademais, o desenvolvimento de políticas de expansão do sistema, considerando de forma sinérgica o acesso e a permanência dos estudantes, contribuirá para que a igualdade de oportunidades se torne uma realidade. (p. 23 )
\end{abstract}

\footnotetext{
${ }^{16}$ O FIES - Programa de Financiamento Estudantil foi criado em 1999 em substituição ao antigo CREDUC. Em 2007 várias regras do programa são alteradas, entre elas o limite de financiamento, que passa a ser de até $100 \%$ do valor da mensalidade para facilitar o ingresso dos alunos às universidades privadas.
} 
A criação do REUNI demandou, por parte do MEC, uma mobilização dos reitores das universidades federais que, através da Associação Nacional dos Dirigentes das Instituições Federais de Ensino Superior - ANDIFES tiveram papel fundamental na implantação dessa política.

O REUNI tendo como principal finalidade cumprir com as metas quantitativas da expansão e de elevação das taxas de conclusão prevê para o cumprimento dessas metas algumas diretrizes que garantam que essa expansão seja realizada com garantia de qualidade acadêmica. Dentre estas diretrizes está prevista a "disponibilidade de mecanismos de inclusão social a fim de garantir igualdade de oportunidades de acesso e permanência na universidade pública a todos os cidadãos" (Brasil - MEC - REUNI).

Dentro da dimensão "Compromisso Social da Instituição" das diretrizes do REUNI estão previstas diversas ações a serem estruturadas e dentre estas, encontram-se as políticas de inclusão e os programas de assistência estudantil.

Dentre as medidas para viabilizar a inclusão no ensino superior público merece destaque aquelas denominadas de Políticas de Ação Afirmativa pelas suas características. Como explica Salvador:

\begin{abstract}
A política afirmativa é geralmente, reconhecida como um instrumento político voltado para a inclusão de grupos subordinados ou subalternizados... Mais do que um meio de inclusão a ação afirmativa também atua em outras frentes, como na promoção de maior igualdade de oportunidades, na redução da discriminação através de ação prática, no campo da consciência da sociedade, na consolidação de espaços mais diversos e ampliação da representação de grupos em situação de desigualdade (2010, p. 7)
\end{abstract}

A adoção das políticas de ação afirmativas, em particular na modalidade da reserva de vagas para ingresso nas universidades públicas está possibilitando que jovens de grupos desiguais como os pobres, negros, indígenas, deficientes físicos, tenham acesso a direitos sociais como a educação.

No entanto, a inclusão na educação superior não se efetiva para um grupo de estudantes se as medidas de democratização do acesso não forem acompanhadas de políticas destinadas a apoiar a permanência na universidade. 
Diante dessa constatação o governo federal institui o Programa Nacional de Assistência Estudantil - PNAES ${ }^{17}$

A aprovação do PNAES, embora dentro do contexto de criação do REUNI é também o resultado de demandas e reivindicações dos setores e profissionais das Instituições Federais de Ensino Superior - IFES organizados no Fórum Nacional de Pró-Reitores de Assuntos Comunitários e Estudantis - FONAPRACE. Desde o ano de1987, quando surge como órgão assessor da ANDIFES o Fórum tem em sua pauta de debates a questão da permanência dos estudantes com dificuldades socioeconômicas que estão ingressando nas universidades públicas a partir das políticas de ampliação do acesso.

Para este Fórum e, em especial para os profissionais que lidam em seu cotidiano profissional com a necessidade de dar respostas concretas às dificuldades diversas que os estudantes pobres enfrentam para realizar seus cursos, a aprovação do Plano Nacional dá um novo status à assistência estudantil desenvolvida nas universidades. A partir do PNAES há uma clara definição das diretrizes para a implementação dos programas e também do público de estudantes em situação de desigualdade social e econômica a que se destinam prioritariamente as ações.

Outro ponto importante em relação à aprovação do PNAES refere-se a destinação de recursos financeiros específicos para o desenvolvimento de programas de apoio a permanência dos estudantes.

É importante salientar que entre os objetivos do PNAES está o de "democratizar as condições de permanência dos jovens na educação superior pública federal" e "minimizar os efeitos das desigualdades sociais e regionais na permanência e conclusão da educação superior" bem como "reduzir as taxas de retenção e evasão" numa relação direta com as metas estabelecidas pelo REUNI.

Ou seja, para além de criar as condições para a permanência na universidade dos estudantes em condições de desigualdade como os que são oriundos das classes populares ou dos grupos étnicos a principal intenção do governo é que essas ações contribuam para a melhoria no desempenho acadêmico desses estudantes a fim de evitar a repetência e a evasão.

\footnotetext{
${ }^{17}$ O Programa Nacional de Assistência Estudantil é criado no contexto do REUNI sendo instituído inicialmente pela Portaria Normativa no. 39 de 12 de dezembro de 2007 e posteriormente pelo Decreto no. 7.234 de 19 de Julho de 2010.
} 
A aprovação do Decreto que instituiu o PNAES decorre da necessidade de que sejam minimizadas situações de retenção e evasão que geram um alto custo financeiro e político para as universidades.

Além disso, o governo almeja que possam ser cumpridas as metas de elevação das taxas de conclusão pelas universidades públicas e, para isso, estabelece objetivos a serem alcançados e as áreas onde as ações de assistência estudantil devem ser desenvolvidas.

Ressalte-se que, a implementação dessa política, não tem nenhuma relação com a promoção de alterações nas condições de desigualdades socioeconômicas desses estudantes fora do ambiente universitário o que fica evidenciado pelo estabelecido no Art. $4^{\circ}$. do Decreto: “as ações de assistência estudantil devem considerar a necessidade de viabilizar a igualdade de oportunidades, contribuir para a melhoria do desempenho acadêmico e agir, preventivamente, nas situações de retenção e evasão decorrentes da insuficiência de condições financeiras" (MEC-PNAES - 2010).

Quer dizer, a assistência estudantil é concebida como um instrumento para prover os recursos necessários ao bom desempenho acadêmico dos estudantes e para que estes possam transpor obstáculos que impeçam a realizam e conclusão de sua graduação.

As mudanças que o sistema educacional brasileiro vem passando nos últimos anos ainda estão longe de promover a efetiva universalização do direito à educação para o conjunto da população. $\mathrm{O}$ acesso à educação pública e de qualidade que desde sempre esteve destinada aos grupos sociais pertencentes às classes dominantes foi um dos fatores que contribuiu para a manutenção da desigualdade social no Brasil.

Nesse sentido, a democratização da educação superior somente se efetivará se tiver como princípios não somente a garantia da ampliação do acesso, mas, sobretudo, a garantia do atendimento às condições para a permanência e formação acadêmica para os estudantes oriundos dos segmentos mais pobres da sociedade que conseguem ingressar na universidade pública.

Desta forma, o tema da assistência estudantil é central no debate sobre a democratização do ensino superior através de políticas afirmativas e, por isto, será abordado de forma mais detalhada na segunda parte desse trabalho considerando o 
seu percurso na Universidade Federal do Rio de Janeiro e no contexto histórico da aprovação do Programa Nacional de Assistência Estudantil - PNAES. 


\section{2 \\ A Assistência Estudantil e seu Papel para a Permanência na Educação Superior}

A Assistência Estudantil pode ser definida como um conjunto de medidas de inclusão social que visa possibilitar que estudantes, em especial os oriundos dos grupos desiguais, tenham condições para a permanência na universidade e realização da formação acadêmica e para que o direito à educação superior possa ser efetivamente alcançado.

Tais medidas devem se materializar num conjunto de ações a serem implementadas para prover aos estudantes o apoio em áreas diversas das necessidades humanas na perspectiva de uma formação ampliada, de um bom desempenho acadêmico e de uma trajetória universitária bem sucedida de modo a evitar a retenção e evasão escolar. Essas ações podem ser de caráter universal, que visam o atendimento de questões que envolvem todos os estudantes independentes de sua condição socioeconômica e cultural, mas principalmente devem ser ações específicas voltadas prioritariamente aos estudantes dos grupos desiguais que estão ingressando em maior número nas universidades a partir das políticas de democratização do acesso à educação superior.

Embora as primeiras iniciativas em criar programas de assistência estudantil datem da década de 30 do século passado ${ }^{18}$ foi somente a partir da aprovação da Constituição de 1988 que a questão da permanência na escola é tratada a partir do princípio da igualdade. Posteriormente, esse mesmo princípio vai ser também tratado na Lei de Diretrizes e Bases da Educação de 20 de dezembro de 1996 que dá o amparo legal para a formulação de programas de assistência estudantil principalmente nas universidades públicas.

A universidade tem como principal função a produção de conhecimento a serviço do desenvolvimento político, econômico, social e científico da sociedade. Mas também deve se tornar um local de democratização desse conhecimento e assumir sua responsabilidade social "aceitando ser permeável às demandas

18 Para um estudo mais detalhado sobre o assunto ver FÁVERO, Maria de Lourdes Albuquerque. Universidade e Poder: análise crítica e fundamentos históricos 1930-1945. Rio de Janeiro: Achimé, 1980. 
sociais, sobretudo àquelas oriundas de grupos sociais que não tem poder para impô-las" (Santos, 2005, p.91).

Esse papel social apresenta desafios a serem enfrentados, como o de garantir as condições para que todos os estudantes que nela ingressam consigam permanecer e concluir sua formação acadêmica.

No entanto, como um espaço que foi ocupado historicamente pelas classes mais favorecidas economicamente, a universidade pública deixou, por muitos anos, essa atribuição relegada a um plano secundário e a existência de programas de assistência ao estudante decorria da necessidade de atendimento à demandas pontuais e isoladas com ações e medidas limitadas e descontínuas.

Ocorre que a partir dos anos 90 há um incentivo por parte do Estado à expansão do ingresso na educação superior concomitante às reivindicações de setores dos movimentos sociais pela ampliação do ingresso nas universidades públicas o que promove um lento, mas gradual aumento do número de estudantes de origem popular e grupos desiguais no interior das universidades.

A universidade reflete e expressa as contradições da sociedade em que está inserida. Em seu interior convivem grupos que defendem a permanência de sua "tradicional vocação para a excelência" (Oliveira, 2011) e aqueles que defendem sua abertura e sua democratização. Esse segundo grupo tem se engajado em movimentos de defesa da democratização do acesso e da criação de condições para a permanência na educação superior pública. Esse é o caso do Fórum Nacional de Pró Reitores de Assuntos Comunitários e Estudantis - FONAPRACE que congrega gestores e profissionais responsáveis pelos assuntos estudantis das Universidades Públicas e que desde 1984 tem demonstrado preocupação com a questão da permanência dos estudantes, em especial aqueles que têm dificuldades socioeconômicas.

Constituindo-se como um órgão assessor da Associação Nacional dos Dirigentes das Instituições Federais de Ensino Superior - ANDIFES esse Fórum foi um importante protagonista para o fortalecimento do debate acerca da necessidade de mecanismos legais que garantissem as ações de assistência estudantil que vinham sendo implementadas de forma fragmentada e descontínua nas diversas universidades públicas.

Tendo como princípio a busca pela redução das desigualdades sociais como parte do processo de democratização da universidade, o FONAPRACE teve 
papel fundamental na inclusão da assistência estudantil no Plano Nacional de Educação - PNE de 10 de janeiro 2001 que determina: “a adoção de programas de assistência estudantil tais como bolsa trabalho ou outros destinados a apoiar estudantes carentes que demonstrem bom desempenho acadêmico" (PNE, 2001).

Essa inclusão da assistência estudantil no Plano Nacional de Educação faz com que ela se conforme como parte integrante da política educacional com a finalidade de viabilizar as condições necessárias para que estudantes pobres possam permanecer na universidade e concluir seu curso superior.

Para subsidiar as discussões em torno da necessidade de uma Política de Assistência Estudantil o FONAPRACE coordenou a realização de 3 pesquisas para traçar o perfil socioeconômico e cultural dos estudantes de graduação das Instituições Federais de Ensino Superior - IFES nos anos de 1997, 2004 e 2010. Os dados coletados nessas pesquisas serviram de parâmetros para a definição e implementação dos dispositivos legais que culminaram com a efetivação da assistência estudantil nas universidades públicas.

Uma das primeiras iniciativas de consolidação de uma proposta de política de assistência estudantil que deu origem ao documento intitulado Plano Nacional de Assistência Estudantil ocorreu mediante o diagnóstico da situação dos estudantes com as pesquisas de 1997 e 2004 e que culminaram na aprovação em 12 de dezembro de 2007 da Portaria Normativa no. 39 que instituiu o Programa Nacional de Assistência Estudantil - PNAES.

Através do referido programa o Estado brasileiro representado pelo Ministro da Educação considera "a centralidade da assistência estudantil como estratégia de combate às desigualdades sociais e regionais, bem como sua importância para a ampliação e a democratização das condições de acesso e permanência dos jovens no ensino superior público federal" (Portaria Normativa 39 de 12/12/2007).

Essa afirmativa representa por parte do Estado o reconhecimento de que as desigualdades sociais e regionais podem ser obstáculos a educação superior e de que a assistência estudantil é mecanismo fundamental nesse processo, contribuindo para a redução das taxas de retenção e evasão nas universidades públicas.

Importante destacar que os documentos elaborados pelo FONAPRACE ao longo dos últimos 25 anos deixam claras as concepções que deveriam embasar 
uma Política Nacional de Assistência Estudantil: de que a democratização do acesso deve implicar na expansão da rede pública de ensino superior, na abertura de cursos noturnos e também na democratização da permanência por meio da manutenção e expansão dos programas de assistência estudantil.

Tem-se, portanto, que a assistência estudantil ao ter por finalidade "prover os recursos necessários para transposição dos obstáculos e superação dos impedimentos ao bom desempenho acadêmico" (Alves, 2002) se constitui como uma política vinculada à efetivação do direito à educação superior

As pesquisas realizadas pelo FONAPRACE apontaram que a principal causa da evasão de um segmento dos estudantes nas universidades são as dificuldades socioeconômicas e, que as universidades que mantém programas de assistência aliados a programas de acompanhamento pedagógico, tem tido um percentual menor dos índices de evasão.

Os debates e reivindicações em relação à inclusão social na educação superior predominaram na última década levando à implementação de políticas de ampliação e de democratização do acesso. No início dos anos 2000 o acesso à universidade era o principal problema em relação à inclusão de grupos desiguais na educação superior questão esta que foi sendo alterada com a criação dos dispositivos legais. Na medida em que estas políticas vêm promovendo uma diversificação do espaço universitário, com a presença cada vez maior de pessoas dos grupos populares, a questão se volta para as condições de permanência desses estudantes.

Nesse sentido, embora a questão da permanência dos estudantes nas universidades fosse uma preocupação de profissionais e dirigentes das Instituições Federais de Ensino Superior - IFES e de setores do movimento estudantil desde o final da década de 80, somente em dezembro de 2007 é instituído um dispositivo legal (a Portaria Normativa no. 39) que vai reconhecer a centralidade da assistência estudantil no processo de democratização da educação superior.

Em relação às condições de permanência Maria Lígia Barbosa afirma que:

Embora a ampliação do acesso a grupos desfavorecidos esteja em tendência crescente, trazendo expectativas positivas em relação à diversificação do público que passa a ter acesso à educação superior, persistem problemas - ainda pouco explorados - para estes grupos permanecerem e concluírem um curso de graduação. (2011, p.3) 
Deste modo, fica claro que, superada a questão do acesso e do reconhecimento da importância da assistência estudantil para a efetivação do direito à educação superior, o foco do debate e das reivindicações deve se voltar para a consolidação do PNAES como política pública de permanência. Espera-se que com essa consolidação seja possível a expansão das ações de assistência estudantil que vêem sendo desenvolvidas nas universidades públicas, com a criação de programas de caráter acadêmico, social e cultural para os grupos de estudantes que deles necessitem.

\section{1.}

\section{Assistência Estudantil no BRASIL - breve histórico}

A assistência estudantil nas universidades públicas brasileiras esteve presente em vários períodos desde a década de 30, com os programas e ações existentes em cada período sendo desenvolvidas de acordo com o momento histórico e o contexto social e político do país. Não é nosso objetivo, no presente trabalho, fazer uma análise detalhada da configuração da assistência estudantil em cada um dos períodos históricos em que esteve presente, seja através de legislações ou de práticas efetivas. Apenas nos propomos a fazer um breve relato de sua constituição no Brasil face à importância que o tema tem adquirido recentemente como instrumento para a efetivação do direito à educação.

Uma das primeiras ações relativas à assistência estudantil foi a construção pelo Governo Getúlio Vargas da 1 ${ }^{\mathrm{a}}$. Casa do Estudante localizada no Rio de Janeiro no ano de 1930 correspondendo a "um casarão de três andares e um restaurante popular que era frequentado por estudantes carentes e membros da comunidade que se faziam passar por estudantes para utilizar o benefício" (Costa, 2010).

Um ano depois, em 1931 foi aprovado o Estatuto das Universidades Brasileiras que previa a organização dos estudantes através de diretórios estudantis ligados aos institutos e faculdades. Ocorre também, neste ano, a primeira tentativa de regulamentação da assistência estudantil com a inclusão na 
Constituição de 1934 de artigo que estabelecia "o repasse de verbas para auxiliar os alunos necessitados através do fornecimento gratuito de material escolar, bolsas de estudos, assistência alimentar e dentária" (Lima apud Costa, 2010).

No ano de 1937 é criada a União Nacional dos Estudantes - UNE que tem apoio do Ministério da Educação para a sua criação e que fica sediada na Casa do Estudante do Brasil, no Rio de Janeiro.

Conforme Kowalski:

Essa foi talvez uma estratégia do governo de construir uma instituição despolitizada e, para isso, a Casa do Estudante do Brasil seria a sede administrativa, responsável em promover a assistência jurídica, bolsas, empregos, biblioteca, saúde e residência. Havia também a proposta, que não foi aprovada, de uma universidade mais aberta, por meio da diminuição das taxas cobradas aos alunos matriculados, consideradas muito elevadas, as quais geravam uma seleção baseada em nível de renda (socioeconômico) e não no mérito acadêmico (2012, p.87)

Nos anos seguintes foram implementadas várias outras regulamentações no campo da educação como na Constituição de 1946 que estabelece a educação como "um direito de todos, que deveria ser ministrada no lar e na escola, com base nos princípios de liberdade e nos ideais de solidariedade humana". Nessa mesma legislação a assistência estudantil é incluída através do artigo 172, ao afirmar que "cada sistema de ensino terá obrigatoriamente serviços de assistência educacional que assegurem aos alunos necessitados condições de eficiência escolar". (Favero, 1980).

O tema da assistência estudantil aparece também na Lei de Diretrizes e Bases - LDB aprovada em 1961 que estabelecia, no artigo 90, a assistência social, médico odontológico e de enfermagem aos alunos, e, no artigo 91, a oferta de bolsas gratuitas aos educandos para custeio total ou parcial dos estudos, com financiamento para reembolso no prazo de quinze anos. A LDB de 1961 colocava a assistência estudantil como um direito que deveria ser garantido de forma igual a todos os estudantes. (Kowalski, 2012).

Posteriormente, no ano de 1970, em contexto político de ditadura militar, é criado pelo Governo Federal o Departamento de Assistência ao Estudante (DAE), que estava vinculado ao MEC e pretendia manter uma política de assistência estudantil para graduandos em nível nacional, dando ênfase para os programas de 
alimentação, moradia, assistência médico-odontológico. Entretanto, o DAE foi extinto nos governos subseqüentes (Fonaprace, 1997).

Falando sobre a assistência estudantil nesse período Fávero descreve:

Dentre alguns benefícios que se previa, destaca-se a concessão de bolsas para determinados alunos, todavia, era necessário haver o entendimento entre professores e estudantes dos conselhos universitários, de que o beneficiado atendesse aos requisitos de modo a cumprir os critérios de justiça e oportunidade. Esses critérios eram embasados nos méritos de cada um sendo que, no caso de pobreza, era preciso comprovar sua situação através da "declaração de pobreza" fornecida por algum instituto assistencial, bem como era observado se o comportamento do sujeito condizia com a pobreza que declarava. Caso ela fosse confirmada, ele se tornava merecedor da bolsa (Fávero, 1980).

Desse modo, considerando que a educação superior no Brasil historicamente destinou-se aos jovens filhos das elites, inferimos que as iniciativas de assistência estudantil criadas nesse período não visavam apoiar a permanência de grupos desiguais. De fato, a assistência estudantil constituía-se principalmente de ações pontuais e limitadas ao atendimento de algumas necessidades básicas como moradia e alimentação, sem que necessariamente houvesse relação da concessão dos benefícios com a condição socioeconômica e de desigualdade social dos estudantes.

Os anos 80, com o início das mobilizações da sociedade pela reconstrução da democracia no Brasil, vão dar uma nova configuração para a questão da assistência estudantil. Em 1987 é criado o Fórum Nacional de Pró-Reitores de Assuntos Comunitários e Estudantis - FONAPRACE numa conjuntura em que já se vislumbravam alterações na realidade social e política do país. O FONAPRACE defendia, desde a sua criação, a maior incorporação de estudantes de grupos populares nas universidades federais ressaltando, no entanto, a necessidade da existência de condições concretas para a permanência desse segmento de estudantes.

Esse período foi importante para o amadurecimento do debate acerca do papel da assistência estudantil na permanência dos estudantes das classes populares que ingressavam nas universidades públicas e pela contribuição para a construção do Plano Nacional de Assistência que deu subsídios para as legislações que se seguiram. 
Entretanto, a década de 90 traz para o cenário político nacional a interferência da ideologia neoliberal em todas as áreas das relações sociais. A Lei de Diretrizes e Bases de 1996 é regulamentada neste contexto e se origina de discussões com a participação da sociedade civil evidenciando uma disputa ideológica entre diferentes projetos para a educação.

Em relação à assistência estudantil, há nesse período uma retração e uma quase total inexistência dos programas por ausência e/ou insuficiência de recursos financeiros. A LDB de 1996 contribuiu para a desresponsabilização do Estado com o financiamento da assistência estudantil nas universidades públicas conforme consta em seu artigo 71, inciso IV: "Não constituirão despesas de manutenção e de desenvolvimento do ensino, aquelas realizadas com programas suplementares de alimentação, assistência médica-odontológica, farmacêutica e psicológica, e outras formas de assistência social “(LDB, 1996).

No entanto, dada às contradições que envolvem todo processo de construção social, a questão da centralidade da assistência estudantil na formação educacional superior volta ao debate com a aprovação em 1998 de documento elaborado pela UNESCO intitulado "Declaração Mundial sobre Educação Superior no Século XXI".

Para Kowalski

Esse documento impulsionou algumas mudanças devido às transformações no contexto econômico e social mundial, as quais acabaram ecoando na educação superior. Frente a essas transformações e o aparecimento de "novas" demandas para educação superior, a assistência ao estudante foi lembrada por essa Declaração, que ressalta a relevância dos programas assistenciais oferecidos nas IES, com a perspectiva de favorecer grupos menos favorecidos, com a finalidade de proporcionar "uma assistência material especial e soluções educacionais que possam contribuir para superar os obstáculos com os quais estes grupos se defrontam, tanto para o acesso como para a continuidade dos estudos na educação superior" (2012, p.94-95)

Ou seja, nesse período há um maior incentivo por parte do governo na expansão da educação superior que tem impulso a partir de algumas situações: o documento da UNESCO; da criação do Plano Nacional de Educação - PNE estabelecida na Carta Constitucional de 1988; o entendimento da educação como estratégia para a redução das desigualdades econômicas; a necessidade de 
formação de uma força de trabalho qualificada, frente às exigências do processo de reestruturação produtiva, entre outras.

O PNE implantado em janeiro de 2001 é aprovado com o objetivo de regulamentar a educação nos seus diversos níveis e modalidades, configurando-se como "plano nacional de longo prazo, com força de lei, capaz de conferir estabilidade às iniciativas governamentais na área da educação" (MEC-PNE, 2001).

O PNE prevê a organização do sistema educacional brasileiro tanto pela via do setor público quanto pelo setor privado que tem, segundo o documento, atribuições e funções diferentes. Em relação à expansão das vagas no ensino superior público o documento define que:

(a) Há necessidade de expansão das universidades públicas para atender à demanda crescente dos alunos, sobretudo os carentes, bem como ao desenvolvimento da pesquisa necessária ao País, que depende dessas instituições, uma vez que realizam mais de $90 \%$ da pesquisa e da pós-graduação nacionais em sintonia com o papel constitucional a elas reservado."; (b) "Ressalte-se a importância da expansão de vagas no período noturno, considerando que as universidades, sobretudo as federais, possuem espaço para este fim, destacando a necessidade de se garantir o acesso a laboratórios, bibliotecas e outros recursos que assegurem ao aluno-trabalhador o ensino de qualidade a que têm direito, nas mesmas condições de que dispõem os estudantes do período diurno (MEC-PNE, 2001)

Assim, o setor público seria responsável principalmente pela coordenação de cursos de pós-graduação e realização de pesquisas necessárias ao desenvolvimento do país além promover a criação de cursos noturnos com condições para maior absorção de estudantes pobres e aluno-trabalhador.

No que se refere à assistência estudantil o mesmo documento estabelece no item 4.4 - Financiamento e Gestão da Educação Superior as seguintes ações:

33. Estimular as instituições de ensino superior a identificar, na educação básica, estudantes com altas habilidades intelectuais, nos estratos de renda mais baixa, com vistas a oferecer bolsas de estudo e apoio ao prosseguimento dos estudos; 34. Estimular a adoção, pelas instituições públicas, de programas de assistência estudantil, tais como bolsa-trabalho ou outros destinados apoiar os estudantes carentes que demonstrem bom desempenho acadêmico (MEC-PNE, 2001). 
Assim, o que se verifica é que a questão da permanência na educação superior não é assunto novo a despeito da pouca relevância que a assistência estudantil teve por muitos anos nas universidades federais. Pode-se considerar que a invisibilidade do tema deve-se a diversos fatores, mas salientamos a questão da ausência de definição específica acerca do financiamento para a realização dos programas nas IFES e a resistência, de parte da comunidade universitária, em aceitar a presença de estudantes oriundos dos grupos mais desfavorecidos econômica e socialmente. O desinteresse, por parte dos dirigentes das IFES, e a ausência de um número significativo de representantes dos grupos desiguais podem ter contribuído para a inexistência, até os dias atuais, de uma política nacional de permanência nas universidades.

A formulação de uma política pública é um processo que envolve disputas de interesses o que faz com que esse processo se torne um caminho longo e permeado de avanços e retrocessos. Nesse sentido, os profissionais e gestores organizados no FONAPRACE se fizeram presentes no debate sobre as mudanças no panorama da educação superior, apontando a assistência estudantil como mecanismo fundamental para cumprimento das metas estabelecidas nos documentos oficiais.

O depoimento de Thérese Hoffmann, integrante da Coordenação Nacional do FONAPRACE nos anos 2000/2001, 2002/2003 e 2003/2004 reflete as complexidades desse processo:

\footnotetext{
Naquela época, o Fórum estava em um momento de autocomiseração. As reuniões eram quase como uma terapia de grupo onde muitos reclamavam que não eram respeitados nas instituições e que as ações de assistência estudantil não eram consideradas estratégicas pelos reitores. Os assuntos do FONAPRACE sempre foram os que mais causavam dor de cabeça nas instituições, ou seja, os restaurantes universitários, as bolsas de permanência e os alojamentos estudantis. Resolvemos mudar este quadro e começamos a agir de forma estratégica e profissional... Nossas ações se intensificaram e começamos a discutir a inclusão de recursos para a assistência estudantil no Plano Nacional de Educação. Começamos a fazer reuniões em Brasília, onde sempre tínhamos pauta no Congresso Nacional e no MEC...Conseguimos mostrar que a assistência estudantil era investimento estratégico para minimizar os impactos na evasão e retenção ... conseguimos dar a base do que veio a ser instituído como o Programa Nacional de Assistência Estudantil - PNAES (Andifes, 2012)
} 
Desse modo, temos que a fase atual em que se encontra a assistência estudantil, na conjuntura do PNAES, teve início em 2007 com a aprovação no 2a . mandato do Presidente Luis Inácio Lula da Silva do Plano de Desenvolvimento da Educação - PDE e foi resultado não somente da necessidade do Estado de ampliação das vagas e da redução das taxas de evasão e retenção, mas também das reivindicações dos movimentos sociais que há décadas demandavam melhores condições para a permanência dos estudantes nas universidades públicas.

O PDE que, no dizer de Saviani (2007) "não constitui um plano, em sentido próprio, sendo definido antes, como um conjunto de ações que, no entanto, não se articulam organicamente" promoveu alterações na expansão da educação superior. No setor público essa expansão ocorreu principalmente com a criação do Plano de Reestruturação e Expansão das Universidades Federais REUNI que tem como objetivo "a criação de condições para ampliação do acesso e permanência na educação superior" e tem como uma de suas diretrizes a ampliação de políticas de inclusão e de assistência estudantil (Art. $2^{\circ}$. Item V).

Desse modo, inaugura-se um novo período para a democratização do acesso, para a implementação de políticas afirmativas e para assistência estudantil nas universidades públicas ${ }^{19}$. Fazem parte desta nova fase as seguintes legislações: o Decreto no. 7.234 de 19 de julho de 2010 que instituiu o PNAES; o Decreto ${ }^{\circ}$ 7416 de 31 de dezembro de 2010 que regulamenta programa de bolsas de permanência para a promoção do acesso e permanência de estudantes em condições de vulnerabilidade social e econômica; a Lei no. 12.711 de 29 de agosto de 2012 que dispõe sobre a reserva de vagas para o ingresso nas universidades federais e o Projeto Lei do PNE para o decênio 2011-2020.

\footnotetext{
${ }^{19}$ Entre os anos de 2010 e 2013 os temas da assistência estudantil e da democratização do acesso ao ensino superior tiveram, além dos avanços na criação de aparatos legais, presença constante na mídia. O jornal O Globo, por exemplo, publicou matérias sobre o assunto entre os meses de setembro de 2012 e janeiro de 2013. Ver ANEXO 1
} 


\section{2.}

\section{Assistência Estudantil na Conjuntura do PNAES}

Embora a criação do PNAES faça parte do pacote de medidas criado pelo governo federal para efetivar a reforma educacional, em especial no âmbito da educação superior, a demanda por programas voltados à permanência dos estudantes de origem popular e dos grupos desiguais nas universidades públicas já vinha ocorrendo há muito tempo por diversos segmentos das Instituições Federais de Ensino Superior. Essa é uma contradição que vem permeando a construção desse processo de ampliação do acesso à educação superior pública e que está conformando a assistência estudantil em nível nacional.

O Estado brasileiro, ao definir como um dos objetivos da Assistência Estudantil, através da criação do PNAES, “minimizar os efeitos das desigualdades sociais e regionais na permanência e conclusão da educação superior" reconhece ser a desigualdade social uma condição que vem impedindo o acesso e a realização da formação acadêmica no nível superior.

O Decreto no. 7.234 de 19 de julho de 2010 que instituiu o PNAES, ao dar prioridade no atendimento aos estudantes em situação de desigualdade social e econômica confere à assistência estudantil um novo status dentro da política de educação superior. No contexto de reestruturação por que passam as universidades públicas, a assistência estudantil é peça fundamental para garantia do sucesso do processo de expansão e democratização e, ainda, para a concretização do direito à educação.

O Programa Nacional de Assistência Estudantil - PNAES vem como resposta à necessidade de garantir uma permanência qualificada no ensino superior público, em especial para os estudantes que se encontram em condição econômica e social diferenciada, e visa viabilizar a igualdade de oportunidades e minimizar as situações de repetência e evasão decorrentes da insuficiência de condições financeiras.

Conforme Alves (2009): 
A finalidade da assistência estudantil consiste em prover aos universitários o acesso aos recursos necessários para a superação de empecilhos que porventura possam prejudicar seu desempenho acadêmico. Desse modo, ela estaria relacionada a diversos setores dos direitos humanos, e por isso ela contempla, além dos meios financeiros para a manutenção do estudante durante o curso, cuidados relacionados à saúde, alimentação, lazer, entre outros. (Alves, 2009, p.1)

Percebe-se que o debate sobre a assistência estudantil indica que é necessária uma multiplicidade de ações para que os alunos tenham condições de maior aproveitamento acadêmico. A educação vista como possibilidade de emancipação humana e de ascensão social, requer o atendimento de uma série de condições objetivas que chegam até nós como expressões das contradições da sociedade capitalista. A universidade como expressão da sociedade brasileira, abriga também essas contradições e isso se reflete na diversidade de situações que o conjunto dos estudantes vivencia no decorrer da graduação. Para os estudantes oriundos das classes populares, em especial, a existência de programas de assistência é de fundamental importância para que haja a igualdade de oportunidades para a continuidade do curso.

Dados do Censo da Educação Superior de 2010 produzido pelo INEP Instituto Nacional de Estudos e Pesquisas demonstram que entre os anos de 2008 e 2010 houve uma expressiva recuperação no percentual de estudantes que concluíram a graduação. O relatório ressalta, no entanto, que este fato pode estar relacionado à ampliação do total de ingressantes no ano de 2007 não fazendo referência a um aumento dos programas de permanência nas Instituições de Ensino Superior.

Pelo mesmo relatório, verifica-se que os anos em que o percentual de concluintes ficou muito abaixo do número de ingressantes, foram anteriores a aprovação do PNAES, o que pode indicar que a ausência de programas de assistência voltados para a redução das dificuldades econômicas dos estudantes pode ter contribuído para essa retenção/evasão.

O PNAES abre uma maior possibilidade para que as universidades públicas desenvolvam programas de assistência estudantil a fim de atender às principais ações elencadas no Decreto e para que institucionalizem suas práticas de apoio à permanência com vistas a uma política de assistência estruturada e articulada às políticas acadêmicas. 
Minha concepção sobre assistência estudantil se norteia pelo entendimento de que a educação superior não irá se efetivar, enquanto direito social, para os estudantes oriundos das classes populares e dos grupos desiguais se não houver, nas universidades, mecanismos adicionais que visem prover os recursos necessários para a superação de obstáculos ao bom desempenho acadêmico e a conclusão da formação.

É difícil imaginar uma sociedade mais democrática e com mais igualdade se o acesso à educação superior continuar sendo privilégio de poucos. $\mathrm{O}$ desafio de reverter esse quadro tem sido enfrentado pelo Estado com implementação das várias políticas de democratização, conforme já analisado neste trabalho. Entretanto, é preciso pensar uma maior inclusão na educação não somente em sua dimensão quantitativa, para onde apontam as políticas de expansão de vagas. É fundamental um olhar e uma atenção especial para as políticas pedagógicas e de permanência que estão sendo oferecidas aos estudantes oriundos de diferentes grupos sociais que estão chegando à universidade.

A expectativa é de que as políticas de expansão e democratização do acesso que vêm sendo implementadas nos últimos anos promovam uma maior incorporação de estudantes das classes populares e dos grupos desiguais nas universidades públicas, o que irá requerer o atendimento de necessidades diversas, tais como moradia, alimentação, apoio pedagógico e psicológico, entre outros.

Ainda que o sistema educacional em seu formato tradicional tenha se mostrado elitizado e excludente, a educação não deixa de ter por finalidade a formação de sujeitos capazes de pensarem por si mesmos, podendo, ainda, ser um elemento de mobilidade social para pessoas das classes mais desfavorecidas economicamente. Pelo acesso aos instrumentos de produção de conhecimento dos quais historicamente estiveram excluídos, os estudantes das classes populares e dos grupos desiguais têm a possibilidade de ocuparem espaços onde se materializam as disputas por diferentes projetos de educação e de sociedade.

Para estes alunos, ingressar no ensino superior é apenas um dos obstáculos a ser vencido. As fragilidades econômicas, sociais e educacionais que uma parcela destes estudantes apresenta ao ingressar na universidade, aliadas às formas diversas de exclusão que irão encontrar no meio acadêmico, podem inviabilizar sua permanência e conclusão de seus cursos. 
Neste sentido, a elaboração da pesquisa e do estudo desenvolvido acerca da assistência estudantil praticada na UFRJ, não pretende esgotar o assunto, mas ser uma contribuição, pela aproximação com a realidade, para se pensar a efetivação de uma política institucional, que vise assegurar as condições para a permanência dos estudantes e a sua formação acadêmica de qualidade.

Nosso entendimento é de que a inexistência de condições para a permanência põe em o risco a oportunidade, criada a partir do projeto de expansão das universidades públicas, de mudança no quadro de desigualdade no acesso à educação superior, o que fará com que as pessoas das classes populares e dos grupos desiguais sofram não uma exclusão $d a$ universidade, mas uma exclusão $n a$ universidade.

\section{3. Assistência Estudantil na UFRJ: dois momentos e dois contextos}

Retomando a questão da implementação dos programas de assistência estudantil nas universidades federais nos reportamos à forma como se configurou na Universidade Federal do Rio de Janeiro - UFRJ a partir da experiência vivida no decorrer de minha trajetória profissional iniciada no final da década de 80 .

A UFRJ que tem uma longa existência e tradição de excelência acadêmica foi, desde a sua criação, um espaço voltado prioritariamente para os jovens oriundos das classes dominantes da sociedade. A despeito de suas características reconhecidamente elitizadas e conservadoras percebi, no decorrer de minha trajetória profissional, a presença de estudantes oriundos das camadas populares ainda que em pequeno número e concentrados principalmente nos cursos de baixa procura. Esse segmento dos estudantes sempre demandou a solução de problemas de diversas ordens, mas principalmente financeiros, para a sua permanência na universidade e o atendimento dessas demandas por parte das diversas gestões que administraram a instituição se deu por muitos anos de forma pontual, fragmentada e por vezes individualizada e personalista. Procuramos fazer um breve resgate da forma como a questão da permanência foi tratada nessa universidade ressaltando o 
lugar periférico que o tema ocupou até recentemente o que se refletiu na escassa produção bibliográfica e teórica sobre o assunto.

\subsection{1.}

\section{Assistência Estudantil na UFRJ - um 1‥ momento}

A UFRJ tem programas de assistência estudantil desde a década de 70. Esse fato é sabido principalmente pela história oral e por alguns poucos documentos encontrados, no início de minha inserção profissional, nos arquivos da Divisão de Assistência ao Estudante que, no entanto, foram perdidos.

No levantamento realizado encontramos alguns documentos organizados em forma de relatórios anuais de atividades ou de projetos para a criação de novos programas, mas nenhum produzido com o intuito de se resguardar a história da assistência estudantil na UFRJ.

Alguns documentos antigos como o Estatuto e o Regimento da UFRJ indicam a Divisão de Assistência ao Estudante como órgão responsável pela coordenação e desenvolvimento dos programas de assistência estudantil na UFRJ. Em 1979, para cumprir o disposto no Regimento da Reitoria, foi elaborada proposta para estruturar e implementar o serviço de assistência e orientação ao aluno conforme descrito no artigo 26: "Ao Serviço de Assistência ao Estudante incumbe promover, em coordenação com a área de ensino de Graduação e Corpo Discente, as medidas de assistência ao estudante" (Anexo 2)

As atividades da DAE foram desenvolvidas, desde sua criação, prioritariamente por assistentes sociais e esta Divisão teve, nas várias gestões, direções ocupadas por professores oriundos da Escola de Serviço Social. Apesar da presença frequente destes profissionais, tanto na direção quanto no corpo técnico, não foram desenvolvidos estudos, pesquisas ou produções teóricas significativas sobre o tema da assistência estudantil que pudessem dar os subsídios necessários à implementação de uma política institucional de assistência estudantil. 
Merece registro algumas exceções a essa lacuna teórica e documental. No ano de 1990 foi elaborado pela então Diretora da DAE, Profa. Maria Durvalina Fernandes Bastos o documento intitulado "Projeto da Divisão de Assistência ao Estudante - DAE" onde se buscava o desenvolvimento de programas e ações de assistência estudantil articulados à formação acadêmica do estudante a ser desenvolvido nos 4 anos seguintes e que apresenta uma concepção de assistência estudantil como parte integrante da formação global do estudante. (Anexo 3)

$\mathrm{O}$ documento produzido pela professora e pelos profissionais da DAE propõe uma nova configuração aos programas que vinham sendo desenvolvidos. Numa tentativa de romper com práticas clientelistas e assistenciais que predominavam na implementação das ações de assistência estudantil, a proposta visava articular essas ações ao projeto acadêmico dos estudantes, buscando dar à assistência estudantil um perfil compatível com as finalidades da instituição universitária.

Para Oliveira:

A articulação das práticas de assistência estudantil com o processo de ensino embora tais ações não se constituam um projeto formal no âmbito do ensino, pesquisa e extensão - pode contribuir para que ocorram mudanças na concepção das respostas dadas aos direitos básicos do aluno. Do contrário, a assistência ao estudante continuará sendo sinônimo de emergência, de improvisação, algo à parte do projeto educacional de formação do profissional cidadão (1997, p. 77 78)

Essa concepção de assistência estudantil ocorre num período em que há no Brasil uma nova conjuntura política, social e econômica, como já analisado em capítulo anterior, e que traz a noção do direito para o debate da assistência estudantil e que o diferencia de outros programas vinculados à assistência social.

Paradoxalmente este foi também um período em que as universidades públicas viveram períodos de crises institucionais e financeiras decorrentes da ideologia neoliberal que predominava a época.

Durante muitos anos a assistência estudantil na UFRJ ficou restrita ao desenvolvimento de alguns programas pontuais e restritos a um apoio financeiro insuficiente e, por vezes necessário apenas para a manutenção de condições mínimas para sobrevivência. Mesmo estes poucos programas sofreram na década de 90 uma descontinuidade e, em alguns casos, uma redução/extinção. Exemplo 
disso foi o fechamento dos restaurantes universitários e a sua substituição pelo programa de Bolsa Alimentação que, pela restrição orçamentária, era em número insuficiente para atendimento de todos os estudantes que utilizavam anteriormente os bandejões ficando restritos aos estudantes que participavam e eram selecionados em processo de avaliação socioeconômica. ${ }^{20}$

Outro documento produzido como esforço de sistematização da assistência estudantil na UFRJ refere-se à dissertação de mestrado da assistente social Egléubia Andrade Oliveira, apresentada ao Programa de Pós- Graduação da Escola de Serviço Social da UFRJ no ano de 1997.

O estudo e a pesquisa buscaram analisar a influência da cultura política brasileira nas práticas de assistência estudantil desenvolvidas em três gestões da universidade, nos anos de 1985 a 1997, e demonstraram uma assistência estudantil constituída de "somatório de práticas sociais, enquanto práticas educativas não formais, realizadas intencionalmente por agentes que objetivam mediar os interesses de indivíduos ou grupos que em muitos momentos são diferenciados ou antagônicos"(1997, p.75)

A leitura do documento revela que por vários anos a assistência estudantil se constituía de práticas baseadas numa cultura política de paternalismo e clientelismo.

\begin{abstract}
$\mathrm{Na}$ análise da trajetória das ações na área da assistência estudantil verificamos que, independente das diferentes gestões de 1985/1997 as práticas de assistência apresentam traços comuns que confirmam que esse é um campo onde os elementos da cultura política brasileira, tais como o clientelismo e o paternalismo são recorrentes, influenciando a tomada de decisões independente do que é propugnado como o papel da universidade (Oliveira, 1997, p. 166).
\end{abstract}

A autora ressalta que a conjuntura política que o país vivenciava naquele período tinha reflexos no interior da universidade como, por exemplo, na mudança do processo de escolhas dos reitores que passa a ser feito por eleições gerais com a participação paritária de toda a comunidade universitária, levando ao estabelecimento:

\footnotetext{
${ }^{20}$ Para mais dados sobre as ações da DAE/UFRJ e das tentativas de implementação de uma Política de Assistência Estudantil no decorrer da década de 90 e início dos anos 2000 ver MENEZES, S. C. - Assistência Estudantil na Educação Superior Publica: O Programa de Bolsas implementado pela Universidade Federal do Rio de Janeiro, cap 5, item 5.2. Dissertação de Mestrado, PUC-Rio, 2012
} 
De compromissos e acordos políticos que passam ao largo de critérios racionais e sustentáveis numa instituição pública... reatualizando velhas práticas políticas que não contribui para a democratização da universidade e obstaculiza práticas condizentes com os direitos de cidadania (Oliveira, 1997, p.166).

Quanto à assistência estudantil, embora tenha havido algumas tentativas de redirecionamento das práticas com o estabelecimento de critérios, racionalização dos recursos e maior articulação e comunicação entre os setores e instâncias da universidade a mesma continuou se configurando como um "conjunto de práticas desarticuladas, de caráter fragmentário e emergencial, constituindo-se num espaço aberto a intervenções não profissionais"(ibidem)

Desde esse período houve algumas iniciativas por parte de segmento dos profissionais da UFRJ em aprovar nos colegiados superiores medidas institucionais para a criação de uma política de assistência estudantil ampliada. Entretanto, isto não ocorreu até o momento a despeito das recentes mudanças na forma de ingresso nos cursos de graduação como a implementação da política de reserva de vagas que será tratada no próximo item deste trabalho ${ }^{21}$.

\subsection{2. \\ Assistência Estudantil na UFRJ - um 2‥ momento e uma nova política}

As políticas de expansão da educação superior implementadas desde 2010 na UFRJ vêm requerendo uma nova configuração para a assistência estudantil. A histórica resistência de parcela da comunidade universitária em promover sua abertura a grupos populares e em alterar suas práticas para o atendimento diferenciado desses grupos se refletiu na pouca prioridade que a assistência estudantil teve até pouco tempo por parte das diversas administrações.

\footnotetext{
${ }^{21}$ Essas iniciativas referem-se a alguns poucos documentos elaborados em 1994 e 2000 pela Escola de Serviço Social e pela Sub Reitoria de Ensino de Graduação e Corpo Discente em 2002 Esse documentos foram encaminhados para o Conselho de Ensino de Graduação e, embora aprovados no colegiado, não se materializaram numa efetiva política de assistência estudantil. Ver Anexos 4, 5 e 6.
} 
A UFRJ ocupa uma posição de destaque no cenário da educação superior pública nacional no que se refere à qualidade de seus cursos de graduação e pósgraduação e na produção acadêmica e científica. Em relação à assistência estudantil, entretanto, não houve por parte das diversas gestões um movimento de torná-la uma política institucional abrangente e consolidada o que nos coloca muito aquém de outras universidades públicas do Brasil, sejam antigas ou recém criadas.

A partir da aprovação do REUNI, das mudanças na forma de ingresso com adesão integral ao ENEM/SISU, da implementação de política de ação afirmativa para alunos egressos de escolas públicas, está havendo uma alteração no perfil de estudante que está ingressando na universidade. Isto vem demandando da instituição novas práticas pedagógicas, novas formas para manutenção e permanência dos estudantes, bem como políticas voltadas para a saúde, inclusão e acessibilidade dentre outras.

Nesta nova conjuntura coube aos profissionais da Divisão de Assistência ao Estudante a reivindicação e pressão para que os recursos financeiros que estavam destinados à UFRJ pelo PNAES fossem utilizados para a ampliação dos programas existentes. Também partiu desses profissionais, em conjunto com estudantes e professores que compuseram um Grupo de Trabalho criado pelo Conselho de Ensino de Graduação, a proposição pela criação de uma nova estrutura administrativa que pudesse dar a definição e a condução das políticas e ações a serem desenvolvidas. Foi também este Grupo de Trabalho que apresentou conjunto de propostas de ampliação da abrangência das ações de assistência estudantil a partir da destinação de recursos específicos para essa área.

A aprovação do PNAES em 2008 representou um novo momento para a assistência estudantil em nível nacional. No caso da UFRJ, embora com recursos financeiros oriundos do PNAES da ordem de R \$ 2.800.000,00 (dois milhões e oitocentos mil reais) não houve num primeiro momento ampliação dos programas que vinham sendo coordenados pela DAE.

A divulgação acerca dos valores do PNAES a serem destinados para as universidades públicas gerou um "repentino" interesse no assunto, conforme apontado por Menezes: 
A assistência estudantil passou a contar com um orçamento bastante substancial, o que gerou um grande interesse político pela temática, com claros reflexos nas campanhas internas para indicação do novo reitor. As quatro chapas candidatas tiveram como uma de suas bandeiras a assistência estudantil e propostas de criação de órgão gestor específico para as políticas direcionadas aos estudantes, o que também acabou por mobilizar o movimento estudantil em torno dessa questão (2012, p 82).

Fica evidenciado pela afirmação da autora que o novo status que a assistência estudantil adquire na UFRJ tem como principal motivação o protagonismo que o tema assume no cenário nacional da educação e que envolve um considerável montante de recursos financeiros.

A gestão que assume a UFRJ em julho de 2011, atendendo às reivindicações dos profissionais da DAE e de parte do corpo discente, cria a Superintendência Geral de Políticas Estudantis/SuperEst:

Instância vinculada ao Gabinete do Reitor, que tem por principal missão constituir-se numa estrutura pedagógico-administrativa voltada ao planejamento, coordenação, acompanhamento e avaliação dos programas e ações direcionados à comunidade discente, buscando a consolidação de uma ampla política de atendimento e assistência aos discentes da UFRJ, visando à disponibilização de condições adequadas para acesso, permanência, condições adequadas para o bemviver na universidade, bom aproveitamento, aprendizado e excelência acadêmica. (Oliveira, 2011)

Deste modo, a criação do Grupo de Trabalho da Assistência Estudantil GT/AE pode ser considerado como um dos primeiros movimentos pela institucionalização da assistência estudantil na UFRJ neste $2^{\circ}$. momento e as discussões e encaminhamentos propostos pelos membros do grupo e aprovados pelo Colegiado tiveram importante papel na criação da Superintendência Geral de Políticas Estudantis/SuperEst.

Cabe ressaltar que a reivindicação, tanto dos profissionais quanto dos estudantes que compunham o GT/AE, como de segmentos do movimento estudantil, era pela criação de uma Pró-Reitoria, a exemplo da forma como a assistência estudantil está estruturada na maioria das universidades públicas, com participação nos Colegiados Superiores, dando a definição e direção das políticas e das ações, saindo desse modo, da esfera meramente administrativa. 
Nestes dois anos de sua existência ${ }^{22}$ a Superintendência vem buscando a consolidação de sua institucionalização, processo este permeado de desafios e dificuldades a serem ainda ultrapassados, mas com avanços que não podem ser considerados pequenos considerando-se a história da assistência estudantil na quase centenária UFRJ.

A nova estrutura criada busca contemplar algumas das áreas estabelecidas no PNAES para o desenvolvimento dos programas de assistência estudantil. Assim, a DAE que até então era uma das Divisões da Pró-Reitoria de Graduação passa a integrar esta nova estrutura continuando com a atribuição de coordenar e desenvolver os programas de bolsas de auxílio e de permanência e de acesso à moradia estudantil.

Para o desenvolvimento de programas na área de saúde, acessibilidade e inclusão, esportes, cultura e lazer são criadas novas Divisões e são incorporados ao corpo técnico da Superintendência profissionais de áreas diversas. As ações e os projetos destes setores têm sido desenvolvidos na perspectiva de uma política ampliada de assistência estudantil que vise o apoio aos estudantes com programas de suporte material (bolsas, moradia), mas também em outras questões que possam interferir na sua vivência acadêmica ou que possam contribuir para uma formação mais diversificada e integral.

Considerando-se que grande parte das universidades públicas se localiza nos centros urbanos e que recebe um significativo número de estudantes de localidades distantes dos seus campi um dos principais apoios à permanência refere-se ao programa de moradia estudantil. No caso da UFRJ, a existência do alojamento estudantil, construído há cerca de 40 anos aproximadamente, tem permitido a realização da formação superior para estudantes sem condições econômicas para custear as despesas com moradia e/ou deslocamento na cidade do Rio de Janeiro. O prédio que tem capacidade para 504 estudantes encontra-se em condições muito precárias, decorrência da ausência de investimentos significativos para a recuperação do processo de deterioração de sua estrutura física e administrativa. Ainda assim, a demanda pela ocupação de um dos quartos é sempre muito maior do que o número de vagas disponibilizadas anualmente.

\footnotetext{
${ }^{22}$ O Conselho Universitário da UFRJ aprovou, em 14 julho de 2011, a criação da Superintendência Geral de Políticas Estudantis (SuperEst), instância vinculada ao Gabinete do Reitor, com status de Pró-Reitoria.
} 
O reconhecimento de que o programa de moradia estudantil representa um apoio imprescindível para a permanência na universidade de um segmento de estudantes, levou a que a recém-criada Superintendência definisse como uma prioridade a realização de uma reforma geral nas dependências do prédio para melhoria das condições de habitação e dos serviços oferecidos. Tendo em vista os procedimentos burocráticos que envolvem os gastos e investimentos com dinheiro público, este processo foi iniciado em 2011 e somente nos primeiros meses de 2013 recebeu aprovação para o início das obras, previstas para começar em julho de 2013 com duração de aproximadamente 300 dias.

A demanda por moradia estudantil vem aumentando muito nos últimos anos na UFRJ. Isto pode ser decorrência do ingresso de um número crescente de estudantes oriundos de locais distantes do Rio de Janeiro e de outros Estados, propiciado pela adoção do ENEM/SISU como forma de acesso aos cursos de graduação e que favorece uma maior mobilidade regional. Essa nova realidade tem demandado a ampliação do programa de moradia estudantil que se verifica com o investimento que está sendo realizado para a construção de novos prédios na Ilha do Fundão

A Superintendência, juntamente aos estudantes, tem apontado para a necessidade de ampliação do programa de moradia e de restaurante universitário também para os outros campi da UFRJ, em especial nos Pólos de Xerém e Macaé. Já é significativo o número de cursos e de estudantes nessas localidades fruto do processo de interiorização da universidade. No entanto, até o momento não houve a efetivação de nenhuma proposta para a construção de moradias ou restaurantes universitários e os estudantes desses locais têm sido atendidos apenas com os programas de bolsas.

Uma questão que é peculiar à UFRJ é o fato do programa de alimentação através dos Restaurantes Universitários/RU`s, considerado questão central para a permanência dos estudantes, não ser administrado pela Superintendência Geral de Políticas Estudantis estando sob a responsabilidade do Instituto de Nutrição. À época das discussões e deliberações pela reconstrução dos RU`s a SuperEst ainda não havia sido criada e o programa de alimentação foi implementado como um serviço para os estudantes mas também como um campo para o ensino e a pesquisa. A interlocução da SuperEst com o Instituto de Nutrição tem sido estabelecida com o intuito de viabilizar a decisão da Administração Central, 
mediante pressão dos estudantes, de construir um novo restaurante universitário no campus da Praia Vermelha, proposta esta não concebida no Plano Diretor da Universidade.

A Superintendência tem, ainda, demarcado seu espaço e sua posição na defesa da assistência estudantil ao trazer para si a atribuição de definição da utilização dos recursos financeiros advindos do PNAES e com isto tem podido promover uma ampliação no número de alunos atendidos nos programas de bolsas auxílio e permanência.

Uma das áreas previstas no PNAES para promover a permanência dos estudantes refere-se ao apoio pedagógico para minimizar dificuldades de ordem acadêmica. Essa é uma questão essencial para uma trajetória escolar bem sucedida e tem relação direta com a redução das taxas de retenção e evasão. A existência desse tipo de programa nas universidades é considerada como medida necessária ao sucesso das políticas de inclusão na educação superior e o seu desenvolvimento requer o envolvimento das unidades acadêmicas e da Pró-Reitoria de Graduação. Embora fundamental, principalmente após a adoção da política de reserva de vagas para estudantes de escola pública, as iniciativas para a criação desse programa ainda estão muito incipientes na UFRJ.

Um aspecto que merece destaque é o compromisso dos profissionais que estão à frente da condução da Superintendência com princípios importantes para a iminente e necessária definição de uma política institucional. Dentre estes, ressalta-se a transparência nas ações e nas decisões, o compromisso com o atendimento de questões específicas dos estudantes de origem popular e dos grupos desiguais, a interlocução e permanente disposição ao diálogo com as representações estudantis legitimamente constituídas e com outras instâncias da universidade na perspectiva de construção de uma política de permanência ampliada e de qualidade. 


\section{3 \\ A Assistência Estudantil da UFRJ na Perspectiva do Estudante}

O desenvolvimento da assistência estudantil na UFRJ tem sido pautado na perspectiva de atendimento, embora restrito e insuficiente, às necessidades materiais básicas dos estudantes com respostas focalizadas em programas de bolsas, moradia e alimentação.

Entretanto, nossa hipótese é de que para alguns grupos sociais a permanência na universidade, o bom desempenho e a conclusão de seus cursos requer o atendimento de outras necessidades, tais como as de saúde e de acompanhamento pedagógico, para que estas questões não sejam obstáculos ou impedimentos à sua formação.

Para corroborar ou desmistificar essa interpretação avaliamos ser importante conhecer um pouco mais sobre a trajetória universitária de estudantes que tem buscado a assistência estudantil como suporte para sua permanência e formação acadêmica. Também buscamos identificar o nível de conhecimento desses estudantes sobre os programas e ações existentes da UFRJ e a avaliação dos mesmos acerca dos programas que conhecem. Para isto, realizamos a pesquisa com estudantes inseridos no programa de moradia estudantil.

Definiu-se como universo da pesquisa estudantes de graduação, moradores da residência estudantil e que ingressaram na UFRJ no ano de 2009, o que totalizava a época das entrevistas setenta e dois (72) estudantes. Decidimos por uma pesquisa de natureza qualitativa, com uma amostragem de $10 \%$ do universo definido, o que representou a realização de entrevistas com oito (8) estudantes. A seleção dos entrevistados foi feita através de sorteio numérico, onde cada estudante recebeu um número. As entrevistas do tipo semi-estruturadas e com roteiro previamente elaborado foram realizadas nos meses de dezembro de $2012 \mathrm{e}$ janeiro de 2013. Para a realização das oito (8) entrevistas foram contatados por email e/ou telefone trinta (30) estudantes.

A escolha do universo a ser pesquisado foi motivada por 2 aspectos: o primeiro refere-se ao tempo em que se encontram na universidade, cerca de 4 
anos, estando próximos de concluírem a graduação; o segundo, por serem estudantes que, pelo fato de residirem no alojamento estudantil localizado no campus da Ilha do Fundão, passam muito tempo de sua vida dentro do ambiente universitário.

As entrevistas com o grupo escolhido possibilitaram um material extremamente rico para o conhecimento das questões e situações que perpassam a trajetória acadêmica dos estudantes e para a análise dos impactos que a existência ou a ausência de uma política de permanência representam para a formação universitária.

A forma como as entrevistas foram estruturadas permitiu que os estudantes pudessem falar de forma aberta e espontânea, expondo as dificuldades, os obstáculos enfrentados e os aspectos positivos ou negativos de sua trajetória na UFRJ.

Do ponto de vista da minha experiência profissional, o contato com estes estudantes e a escuta de seus relatos possibilitou uma maior compreensão das situações que essas pessoas vivenciam nesse período de suas vidas e sobre o papel da assistência estudantil nas suas trajetórias na universidade.

A análise dos dados coletados, das falas e depoimentos dos entrevistados será apresentada seguindo a forma como foi estruturado o roteiro de entrevistas com o agrupamento das questões levantadas organizadas em quatro blocos de análise: o primeiro que identifica o perfil do estudante entrevistado; um segundo momento em que se buscou conhecer as dificuldades e facilidades vividas para a realização do curso; um terceiro momento em que se busca identificar o conhecimento dos estudantes acerca dos programas existentes na UFRJ e por último são analisados os relatos onde os entrevistados fazem avaliação acerca da assistência estudantil existente e dos aspectos que consideram importante para a permanência na universidade. 


\section{1. \\ O Perfil do Estudante Entrevistado}

Os estudantes entrevistados são na maior parte jovens entre 20 e 30 anos, 6 são do sexo masculino e 2 do feminino e todos são solteiros. Em relação à cor $63 \%$ deles se auto identificam como de cor branca, $25 \%$ se identificam como negros e $13 \%$ se consideram pardos. (Gráficos abaixo)

Gráfico 1- Sexo

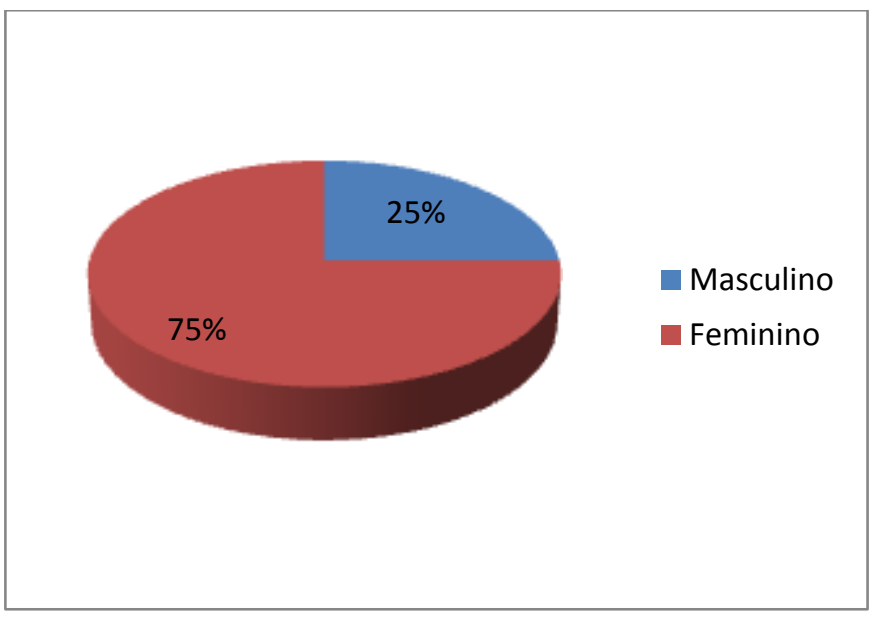

Fonte: própria autoria.

Gráfico 2- Raça

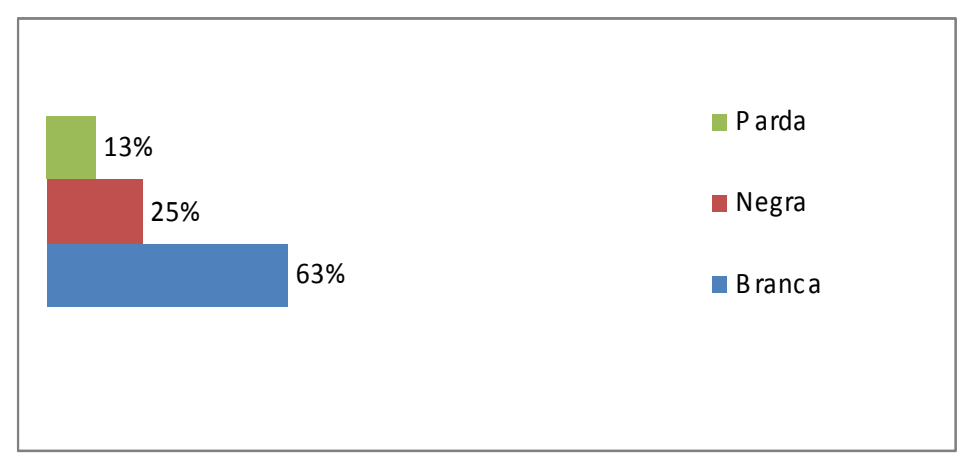

Fonte: própria autoria.

Em relação à origem social dos estudantes, os dados apresentados na tabela abaixo indicam que, na totalidade, são oriundos das classes menos 
favorecidas, com a renda das famílias situando-se na faixa de 1 a 5 salários mínimos.

Tabela 2- Renda Familiar

\begin{tabular}{|c|c|c|}
\hline \multicolumn{1}{|c|}{ RENDA } & ESTUDANTES \\
FAMILIAR & ENTREVISTADOS & $\%$ \\
\hline $\begin{array}{c}\text { De 1 a 3 s.m. } \\
\text { (R \$ 678,00 a R\$ 2.034,00) }\end{array}$ & 06 & $75 \%$ \\
\hline $\begin{array}{l}\text { De 3 a 5 s.m. } \\
(\mathrm{R} \$ 2.034,00 \text { a } \mathrm{R} \$ 3.390,00)\end{array}$ & 02 & $25 \%$ \\
\hline
\end{tabular}

Fonte: própria autoria.

Os estudantes são, em sua maioria, oriundos de escolas da rede pública de ensino e somente 1 dos estudantes fez o ensino médio em escola particular com bolsa integral. Destes, apenas 1 dos entrevistados não frequentou curso prévestibular ou preparatório para ingresso na universidade.

Em relação à escolha do curso, 50\% dos entrevistados declararam terem escolhido as carreiras por aptidão e vocação conforme os relatos abaixo:

[....] Eu sempre gostei muito de casa... Aí há muito tempo, eu estava tipo na sétima série, eu decidi que eu queria fazer Arquitetura, olhando assim projetos e tal... (Estudante de Arquitetura)

[....] Eu sempre quis ser professor, aí eu só escolhi a matéria. No pré-vestibular eu fui ver qual a matéria que eu realmente gostava. Eu ficava ali na dúvida entre Educação Física, Geografia, Física e Química... Aí eu descobri que Física era o que eu queria dar aula. (Estudante de Lic. em Física)

[...] Relações Internacionais? Eu gosto da diplomacia. Eu gosto da diplomacia desde cedo... Mesmo quando eu queria entrar pro IME, o meu planejamento era fazer o IME e depois ir pra escola da diplomacia. Então acho que... Algumas coisas que acontecem no mundo, assim, no país, nacionalmente, têm muita interferência internacional, por causa de acordos e protocolos que assinam.. então eu gostaria de estar participando desse processo. (Estudante de Relações Internacionais)

Os discursos demonstraram que metade dos entrevistados escolheu os cursos que realmente desejava. Porém os outros $50 \%$ afirmam que a escolha profissional não foi feita por vocação, mas principalmente por necessidade de melhorias do nível econômico. Isto nos faz concluir que a possibilidade de 
inserção no mercado de trabalho e o retorno financeiro também pesam na decisão dessa escolha, como relatado por um dos entrevistados: "Primeiro eu tinha em mente, tipo assim, eu quero alguma coisa que me dê um retorno rápido. Não tem professor de química no mercado. Ah, vou fazer depois bacharel, vou fazer engenharia...”. Quer dizer, os estudantes entrevistados fazem suas opções profissionais de forma vocacional e também pelo aspecto financeiro.

Os relatos indicam que a escolha da profissão é uma decisão que, em geral busca conciliar os gostos e afinidades pessoais com a expectativa de mobilidade social e retorno financeiro, cujas possibilidades aumentam com uma formação superior.

Há que se considerar, também, que a origem social desses estudantes contribui para a escolha do curso. Entre os entrevistados $63 \%$ têm na família outras pessoas com curso superior ou cursando universidade, em geral irmãos ou primos. Isto significa que se trata da $1^{a}$. geração de estudantes universitários, tendo em vista que somente 1 dos entrevistados tem um dos pais com curso superior completo.

Um dado que merece destaque é que apenas metade dos pais completou a formação básica, ou seja, o ensino fundamental e médio, como demonstrado nos gráficos abaixo.

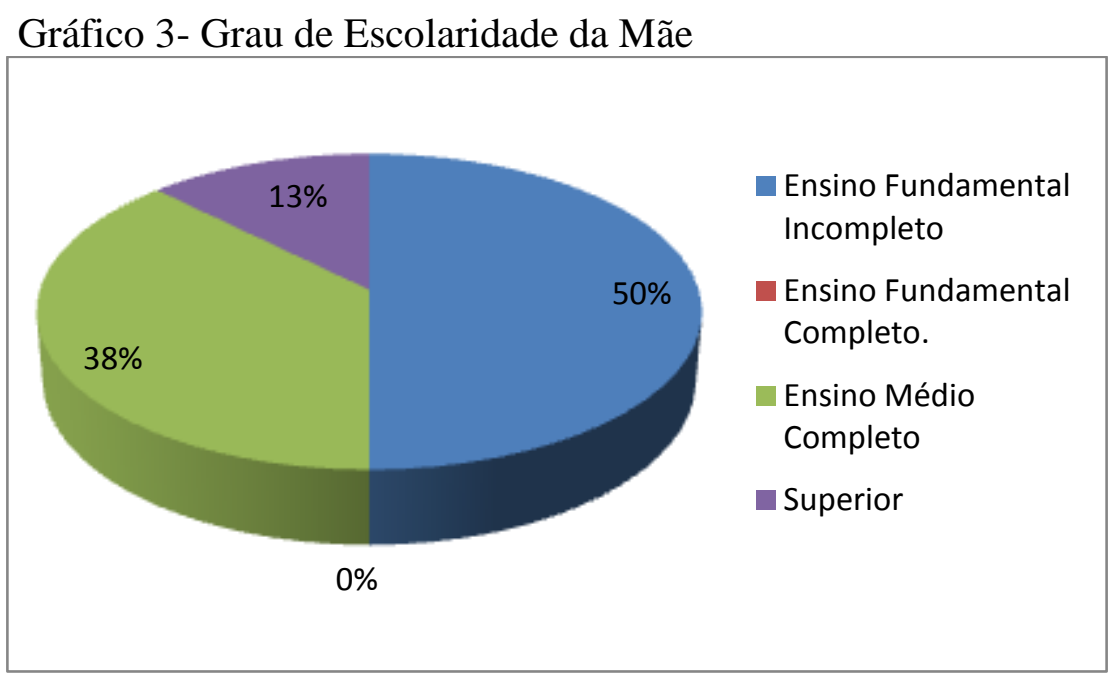

Fonte: própria autoria. 
Gráfico 4- Grau de Escolaridade do Pai

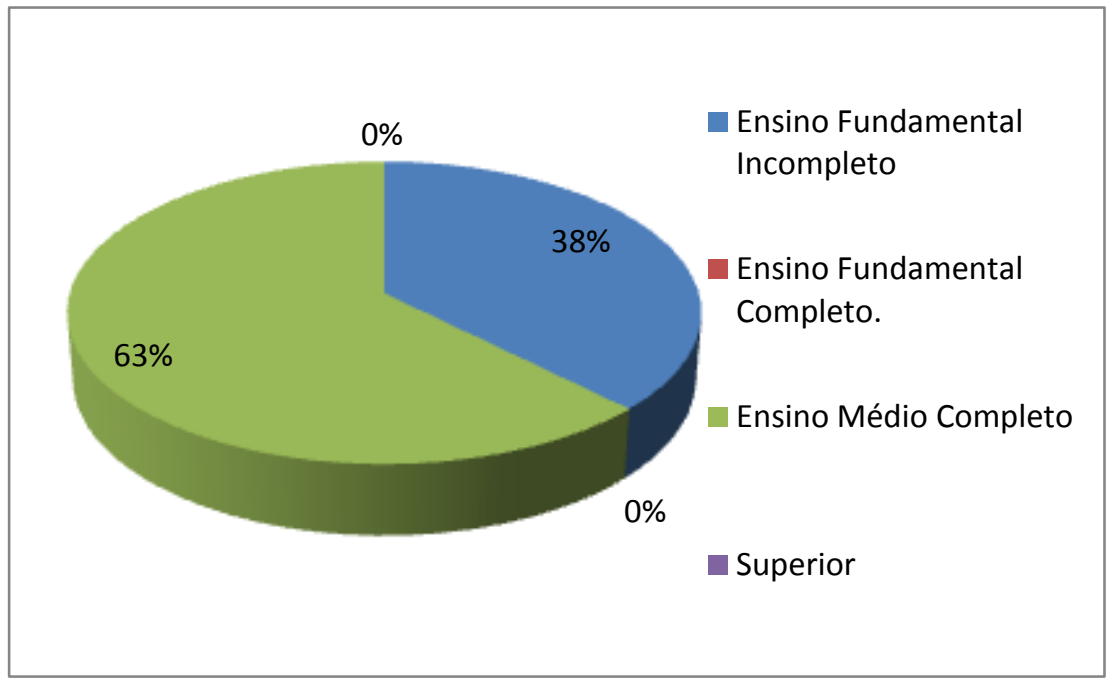

Fonte: própria autoria.

Em relação à profissão dos pais e mães, no total de 16 pessoas, 5 delas estão inseridas no mercado formal de trabalho, desempenhando funções como: professor de ensino fundamental, motorista de ônibus, zelador, auxiliar administrativo e gerente de comércio. Um dos pais encontra-se aposentado, 2 mães não exercem atividade remunerada e os demais exercem atividades no mercado informal como costureira, motorista, empregada doméstica, diarista, vendedor ambulante, marceneiro, agricultor e músico.

Através destes dados pode-se verificar que, além do grupo de estudantes entrevistados ser a $1^{\text {a }}$. geração de universitários na família, a maioria dos pais e mães desempenham atividades que requerem pouca escolaridade. Embora estes dados não possam ser compreendidos numa perspectiva de totalidade eles mostram o pouco acesso dos brasileiros à universidade. Isto referenda a desigualdade no acesso à educação superior da qual, muitos jovens de origem popular e de grupos desiguais, encontra-se alijado.

A educação superior esteve sempre destinada aos segmentos da população com melhores condições econômicas e sociais. A negação do direito à educação superior para pessoas das classes menos favorecidas contribuiu para a manutenção e reprodução de uma organização social extremamente desigual. A desigualdade social que predominou na história do desenvolvimento do país ainda se mantém em índices bastante elevados, tanto no aspecto da distribuição de renda quanto na dimensão do acesso a bens e direitos sociais como a educação. 
No caso da educação superior, as recentes políticas de democratização do acesso a este nível da formação educacional estão possibilitando uma lenta, mas gradual reversão desse quadro, com a presença de um número maior de jovens oriundos das classes pobres e dos grupos desiguais na universidade.

Esta mudança no perfil do estudante da UFRJ pode ser evidenciada quando se constata que, como visto anteriormente, a faixa de renda das famílias dos entrevistados é de 1 e 5 salários mínimos ${ }^{23}$, o que confirma que os estudantes moradores da residência estudantil são oriundos de classes populares. Isto também pode ser comprovado através dos próprios depoimentos quando afirmam que não pedem apoio financeiro à família devido às dificuldades econômicas: "Não, eu nunca dependi da renda da minha mãe... Quando ela consegue vender alguma coisa, vender alguma roupa, ou quando surge trabalho de carnaval normalmente ela consegue cerca de 200, 250 por semana, isso na época do carnaval. Fora do carnaval eu acho que ela consegue pegar mesmo estourando uns 500 reais."

No que se refere ao próprio sustento do estudante e à sua permanência na universidade os estudantes relatam que contam com a ajuda das bolsas assistenciais e/ou acadêmicas, realização de estágios e trabalhos informais. Em relação a essa situação alguns depoimentos merecem destaque:

[...] Ah, a despesa que eu tenho aqui... Eu estando no alojamento eu tenho que comprar minha comida, tenho que comprar minha roupa. Eu tenho que me virar por completo... Com a bolsa do alojamento ajuda uma parte. Dá pra comprar uma comida, dá pra garantir o gás, dá pra garantir alguma coisa. O restante das despesas foi o que eu falei... Vai dando uma aula aqui, uma aula ali pra conseguir mais alguma coisa, e vai se virando...

[...] No momento eu tenho a bolsa de auxílio moradia e a bolsa de pesquisa... Que eu faço pesquisa, tô num núcleo de pesquisa, o NIAC. E eu tô arcando com as despesas assim...

[...] Então, eu tenho a bolsa do alojamento e eu faço estágio, então seriam duas bolsas e isso me permite ficar legal, assim... Consigo suprir minhas necessidades bem tranquilamente....

Para a maioria dos entrevistados a ajuda da família é somente em último caso:

\footnotetext{
${ }^{23}$ A época da realização das entrevistas o valor do salário mínimo era de $\mathrm{R} \$ 678,00$
} 
[...] não peço nada pra minha mãe, nem pro meu pai, nem pra ninguém. É tipo situação extrema. A única vez que eu me lembro que pedi pra minha mãe é que eu tava com 220 reais na carteira, aí eu cometi a besteira de sentar, a carteira incomodou, eu coloquei a carteira em cima do computador. Aí eu saí da sala, lembrei, voltei pra sala, a carteira não tava mais lá. Aí eu perdi 220 reais, aí não tem como. Aí eu pedi pra minha mãe e minha mãe me deu. Mas é situação assim de extrema necessidade. Caso contrário eu não incomodo não porque eu sei a situação de casa.

[...] Não, a minha mãe não me ajuda em nada. Ela tava me dando até uma ajuda com o cartão alimentação que ela tem. Só que quando eu passei pra pesquisa aí eu devolvi o cartão. Porque ela também precisa, né? E eu como sou sozinha, tenho despesa só comigo, eu achei que era mais coerente entregar a ela de volta.

[...] não, na verdade eu nunca dependi dos meus pais, nunca... Desde que eu fazia o cursinho eles nunca me deram dinheiro pra nada, porque eu já trabalhava, entendeu... E aí hoje eu ajudo em casa ainda. Hoje já que eu consigo me manter aqui, eu ainda ajudo em casa com o que é possível.

Pelos relatos observa-se que esta relativa autonomia financeira dos entrevistados em relação às famílias só é possível pelo fato de estarem inseridos em programas de assistência estudantil como o alojamento e a bolsa auxílio. Os relatos evidenciam, ainda, que somente os programas de permanência não respondem pela totalidade das necessidades dos estudantes. A restrição dos programas os impele a buscar uma complementação financeira seja através de estágios ou de outras atividades.

[...] eu recebo bolsa do alojamento, recebo bolsa do PIBID, que é da Capes, tenho esse outro estágio que é de uma empresa particular. E assim, eu já dou aula de química, aula particular, aula no pré-vestibular e aula no ensino médio.

Quer dizer, para estudantes oriundos de famílias de baixa renda a impossibilidade de dedicação integral ao curso é uma constante, sendo necessário dividir seu tempo entre os estudos e a busca pela sobrevivência, recorrendo muitas vezes, para esta sobrevivência, ao acumulo de bolsas acadêmicas e assistenciais. Isto demonstra que para o estudante de classe popular a manutenção na universidade é uma realidade que exige uma gama de atividades que extrapolam os limites da dimensão acadêmica. Os reflexos da pobreza podem impactar na formação acadêmica e social desses jovens, por restringir uma vivência mais 
ampla e integral da experiência universitária. Para esse grupo de estudantes há a perpetuação da condição de desigualdade e, apesar de terem conseguido ingressar numa universidade pública, as suas trajetórias acadêmicas são permeadas por dificuldades de diversas ordens, para além das dificuldades de ordem financeira, mas que, em geral, são determinadas pelos aspectos econômicos.

Neste sentido, as ações de assistência estudantil e programas de permanência devem ter como foco esse segmento de estudantes e devem ter como objetivo proporcionar desde o apoio à sobrevivência mínima, com o provimento de recursos materiais até o suporte às questões de saúde, às necessidades de acompanhamento pedagógico, o acesso à cultura e ao lazer, entre outros. Essa é uma concepção que considera que a assistência estudantil deve se constituir numa política pública de permanência que garanta aos estudantes de classes populares condições favoráveis para uma formação superior com qualidade.

$\mathrm{Na}$ análise do perfil socioeconômico, o local de moradia do estudante antes de seu ingresso na universidade é um dado indicativo de sua condição de vida. Em geral, as cidades são divididas entre bairros centrais, com melhor oferta de serviços públicos, como, por exemplo, os transportes coletivos e bairros de periferia onde esses serviços são precários e em quantidade insuficiente. Quer dizer, a inexistência de serviços públicos em condições adequadas às necessidades dos usuários é um problema que os estudantes oriundos da periferia vivenciam para conseguir realizar o deslocamento diário para a universidade.

Entre os estudantes entrevistados verificou-se que uma parte é constituída de moradores de cidades de pequeno porte e distantes do Município do Rio de Janeiro (Petrópolis, Teresópolis, Nova Iguaçu) e moradores da periferia do Rio de Janeiro (Santa Cruz, Paciência, Ilha de Guaratiba). Essas são localidades do Rio de Janeiro que, além de distantes da universidade têm reduzida oferta de transporte público e com valores de passagens muito altos, o que representa um obstáculo ao deslocamento diário para estudantes de baixa renda. Desse modo, um dos principais problemas apontado pelos estudantes é o transporte público devido ao seu alto valor econômico quanto às longas distâncias.

Estes dados referendam que o programa de moradia estudantil tem função primordial para a permanência de estudantes que, além das dificuldades socioeconômicas, residem em locais distantes da universidade. 
Um dos problemas atuais das universidades brasileiras é que está havendo um aumento, via reserva de vagas, no número de estudantes de classes populares, de cidades do interior e de outros Estados. Estes estudantes buscam moradia na universidade seja pela condição financeira e também pela distância. Este novo contexto está gerando uma mudança no perfil dos estudantes que têm sido atendidos pelo programa de moradia estudantil.

Até o ano de 2011 estudantes moradores de municípios do Rio de Janeiro como Belford Roxo, São Gonçalo, Nova Iguaçu, e também de bairros distantes dos campi da UFRJ como Campo Grande, Sepetiba, Santa Cruz, conseguiam ser atendidos pelo programa de moradia. Exemplo disso é o local da residência da totalidade dos estudantes entrevistados que ingressaram na UFRJ no ano de 2009 e foram selecionados para o benefício moradia no mesmo ano.

A partir de 2012 e, principalmente no ano de 2013, começa a haver alteração no perfil dos estudantes que são inseridos no programa de moradia, com prioridade para os estudantes que residem em municípios distantes do Rio de Janeiro e em outros Estados. Neste contexto, os estudantes oriundos da periferia e de bairros populares, mesmo com todos os problemas relativos ao transporte público e à baixa condição econômica da família têm poucas possibilidades de serem beneficiados com a vaga na residência estudantil. Embora alguns desses estudantes consigam apoio financeiro, através das bolsas de auxílio, para poderem arcar com o custeio de passagens e alimentação, em alguns casos, esse apoio é insuficiente para garantir a permanência e continuidade dos cursos. Os relatos a seguir exemplificam esta realidade:

[...] Eu acho que devia ser mais... Ter maior quantidade de alojamento. Porque eu conheço uma menina da EBA, que ela é muito pobrinha assim... Ela mora depois de Niterói, muito longe e ela até hoje não conseguiu alojamento. Eu acho um absurdo, sabe? É longe, eu acho que ela precisaria e ela desistiu de tentar porque ela não consegue. O pai dela é carpinteiro, sabe? Eu acho que consegue pegar muito poucas pessoas.

[...] Uma coisa que seria ótimo se tivesse, que isso até pegaria muita gente que mora não tão perto, mas relativamente longe, no Rio, mas longe, sabe... Tipo lá no fundo de Niterói, ou então sei lá, em Santa Cruz... Nem sempre consegue bolsa auxílio, porque o alojamento realmente é muito concorrido. Eu mesma já tentei outras vezes e não consegui, consegui no terceiro período... Por causa de renda familiar, porque não tá dentro, mas também não dá pra pagar aluguel. Seria bom se tivesse um alojamento que tivesse sei lá... Que não desse a bolsa, só fosse o alojamento, ou então sei lá... Tivesse um aluguel que puxasse só a manutenção 
mínima, que fosse cinquenta, cem reais. Acho que nossa... Ajudaria muita gente com certeza....

Os dados apresentados no quadro abaixo demonstram a alteração em relação ao local de origem do estudante que tem sido atendido pelo programa de moradia estudantil.

Quadro 1 - Alteração em relação ao local de origem do estudante que tem sido atendido pelo programa de moradia estudantil

\begin{tabular}{|l|c|c|c|}
\hline \multicolumn{1}{|c|}{ Beneficio Moradia } & 2009 & 2011 & 2012 \\
\hline $\begin{array}{l}\text { Alunos selecionados residentes em bairros } \\
\text { distantes e Municípios próximos do Rio de }\end{array}$ & 53 & 53 & 46 \\
$\begin{array}{l}\text { Janeiro (Paciência, Santa Cruz, Nova Iguaçu, } \\
\text { Petrópolis, Araruama,...) }\end{array}$ & 34 & 22 & 34 \\
\hline $\begin{array}{l}\text { Alunos selecionados residentes em Municípios } \\
\text { distantes do Rio de Janeiro (Nova Friburgo, } \\
\text { Macaé, Volta Redonda...) }\end{array}$ & 34 & 38 & 76 \\
\hline $\begin{array}{l}\text { Alunos selecionados residentes em outros } \\
\text { Estados }\end{array}$ & 16 & & \\
\hline
\end{tabular}

Fonte: Divisão de Assistência ao Estudante/UFRJ.

Pode-se verificar que, nos três anos levantados, se mantém o número de estudantes que são selecionados para a moradia estudantil oriundos de bairros distantes e Municípios do Rio de Janeiro e que vem crescendo muito o número de estudantes provenientes de outros Estados do Brasil. ${ }^{24}$

O que se pode perceber pelos dados apresentados e pela experiência cotidiana do trabalho profissional é que a ampliação dos programas de assistência estudantil, em especial o programa de moradia, não está ocorrendo na mesma proporção do aumento de vagas e do acesso à universidade de pessoas que demandam esse serviço. Esta é uma situação que pode comprometer a permanência de um segmento dos estudantes e o cumprimento das metas de elevação global das taxas de conclusão e de inclusão social, conforme estabelecido no REUNI e no PDE.

Nesse sentido, não se pode considerar que está ocorrendo, de fato, uma garantia do direito à educação superior para os estudantes pobres que, a despeito

\footnotetext{
${ }^{24}$ Não foi possível apresentar os dados de 2013 para a moradia estudantil, pois no período de levantamento das informações o processo seletivo ainda encontrava-se em curso. Entretanto, um levantamento preliminar indicou que a situação de moradia dos estudantes que solicitam inserção no programa e tem possibilidades de serem contemplados permanece como a apresentada nos anos anteriores.
} 
de terem ingressado numa universidade pública, não conseguem se inserir num dos programas de assistência estudantil permanecendo, assim, para estes estudantes um processo de exclusão.

\section{2.}

\section{A Permanência na Universidade: facilidades e dificuldades}

O ingresso de estudantes de grupos populares e de grupos desiguais nas universidades públicas é uma tendência crescente indicando que o problema do acesso desses grupos à educação superior está, em parte, resolvido. Entretanto, ainda persistem problemas pouco explorados no que se refere à permanência e conclusão dos cursos para estes estudantes (Barbosa, 2011), o que pode determinar a efetivação e a qualidade da formação superior.

Quando perguntados sobre as principais facilidades e dificuldades vividas, as respostas dos estudantes entrevistados foram as mais diversas, indo desde sentimentos de alegria pela realização de um sonho e de preocupação com as condições concretas para realizar o curso:

[...] na época que eu fiz o vestibular, pra mim a UFRJ era a melhor, aí eu escolhi ela. Tanto que eu só fiz vestibular pra ela... então quando eu passei, quando vi o resultado, foi muito legal, eu ia poder fazer alguma coisa envolvida com arte, já que eu sempre gostei de desenhar... mas o material, tela, tinta, essas coisas... papel... é tudo muito caro. Papel, acho que é mais caro do que as telas em si....

[...] Eu venho de um lugar onde o nível de escolaridade das pessoas é baixíssimo, baixíssimo. Eu acho que do bairro eu devo ser, no bairro de não sei... Umas mil pessoas... eu devo ser, devo estar entre os dez que estão numa universidade, e certamente o primeiro que está numa pública. Para mim isso é uma coisa bem significativa... tem a questão do gasto com material do curso... eu vou lá e pago os materiais e meu pai me ajuda com uma parte. A gente vai dividindo. Mas eu evito evitar ficar pedindo dinheiro pra ele porque ele já ajudou muito minha irmã...

A maioria dos estudantes tinha consciência das dificuldades que teriam que enfrentar para conseguir cursar a universidade ainda mais pelo fato de que a 
maioria deles ingressou para curso de horário integral, o que dificulta a conciliação entre estudar e trabalhar.

[...] Eu não tenho família no Rio de Janeiro... E assim, foi uma situação meio complicada a questão da moradia... O primeiro ano eu fiquei morando na casa da avó de um amigo meu que mora aqui... a gente não tinha condição total de pagar um aluguel...

[...] No início eu pensei em desistir do curso... no primeiro ano. Porque eu fiquei um ano morando, dormindo em casa de amigos lá no Vidigal, aí dormia dois dias no alojamento porque já tinha conhecidos do curso que moravam lá, mas não dava pra dormir todo dia. E aí eu fiquei meio assim... Desestimulada, desanimada, porque... Vem tudo de uma vez, né? Você não tem onde morar, você também tem dificuldade de pagar...

Os relatos indicam que em relação às dificuldades encontradas na trajetória universitária, a grande maioria aponta o aspecto financeiro para arcar com as despesas com alimentação, material didático e participação em atividades extracurriculares, como sendo o principal obstáculo para a permanência na universidade.

[...] Às vezes nem sempre dá tempo de adequar estágio, curso, ao horário do bandejão. Às vezes é uma fila muito grande, então aí o almoço aqui sai quase dez reais... dez reais todo dia não dá pra bolsa que a gente recebe do auxílio do alojamento.

[...] Os livros, as xerox conta muito... E as atividades extra acadêmicas, que são participações em seminários...alguns são pagos, outros não são, mas precisa se deslocar, você precisa de um lanche, então... Alimentação também conta muito, mas dá pra levar. Mas as xerox, os livros, essas coisas são... O peso é muito grande pra poder conseguir se manter na faculdade.

Além das despesas com alimentação e aquisição de livros, alguns estudantes também apontaram as despesas com a compra de material específico necessário para a realização de cursos como Pintura e Arquitetura, como papéis, lápis e tintas especiais, pranchetas, telas, etc.: "material... boa parte das vezes não dá pra aproveitar... E eu tô fazendo TI agora, então a gente gasta uma fortuna com pranchas, material..."

Deve-se salientar que, pelo fato de residirem na moradia estudantil, estes estudantes não consideraram os gastos com transporte. Entretanto, destacam que, 
caso não estivessem inseridos nesse programa, o gasto com passagens pesaria muito:

[...] Ah, é porque eu tenho alojamento, mas sem o alojamento é passagem...Era a situação antes, eu antes tinha que subir e descer todo dia. O emprego que eu tinha me garantia passagem de ida e volta pra casa. Mas é isso... Eu acho que a despesa maior de vir pra cá pro Fundão, o gasto primordial é a passagem"

[...] Ah, aqui dentro a gente tem transporte interno, né? Que não cobra nada. Então no alojamento não tem gasto de transporte... Do alojamento pra cá, e nem gasto pra ir pra Praia Vermelha, mas fora isso acho que...

Os entrevistados também apontaram que além dos gastos financeiros o deslocamento diário para a universidade é uma dificuldade que pode interferir e até interromper a trajetória acadêmica, evidenciando a importância do programa de moradia estudantil:

[...] seria ótimo se tivesse, que isso até pegaria muita gente que mora não tão perto, mas relativamente longe, no Rio, mas longe, sabe... Tipo lá no fundo de Niterói, ou então sei lá, em Santa Cruz... Nem sempre consegue bolsa auxílio, porque o alojamento realmente é muito concorrido... Eu tenho uma amiga que era de Itaguaí, que ela surtou. Ela teve que trancar a faculdade pra fazer tratamento médico. Estafa total..."

[...] Porque você gasta um tempo muito absurdo dependendo de onde você for. O pessoal que estuda aqui não mora só na Ilha, ou Bonsucesso, Olaria.. Tem gente que vem de Belford Roxo, de Caxias. Tenho amigos lá na Física que moram em Xerém. Pegou um engarrafamento no meio caminho, danou-se, não vai chegar na aula nunca. Tem pessoas que vem do Maranhão, vem do Piaú, vem de outros lugares... Vai ter despesa com aluguel... Mas acho que a primordial despesa é a passagem.

Foi consenso entre os estudantes entrevistados que o fato de residirem na moradia estudantil é uma facilidade para a permanência na universidade. Entretanto, as respostas indicam outros tipos de dificuldades que os estudantes vivenciam tais como as condições e limitações físicas do prédio da moradia:

[...] Ah o alojamento tá muito, muito precário...Aí nem sempre eu posso ficar lá, porque pode faltar luz de repente e eu não vou poder fazer meu projeto pra amanhã, aí tenho que ir pra casa de alguém....

[...] Você não tem comunicação fora porque não tem internet. O sinal é muito ruim, então você tem a pressão de entregar um trabalho no outro dia sem internet, 
e tem que se virar. Então, tipo, é tudo complicado nesse sentido. Uma coisa vai somando à outra.

Houve, ainda, estudantes que apontaram outro tipo de dificuldade que se refere às relações interpessoais entre os moradores da residência estudantil. Embora esta dificuldade não tenha relação direta com a sobrevivência material do estudante, faz com que a permanência na universidade seja uma experiência complexa e por vezes dolorosa. Esta realidade ficou bastante evidenciada em alguns relatos:

[...] Acho que lá no alojamento, o ambiente te ajuda porque você veio de um lugar distante e consegue um espaço pra você poder ficar perto da faculdade e te ajudar. Mas ao mesmo tempo é um ambiente muito tenso...Tem problemas de relacionamento que é difícil de se resolver, o clima é estranho, é difícil pra caramba... você encontra lá as situações mais extremas possíveis. O que você pode imaginar você encontra lá dentro. Então é difícil... Resolver as dificuldades lá do alojamento é sempre muito difícil...

[ ...] Também tem uma parceira porca demais, então já aconteceu várias vezes de eu ter que sair porque ela fez uma imundície lá. Aí assim... As grandes dificuldades pra mim são lidar com as pessoas de lá. Eu acho que o grande problema não é nem a estrutura, são as pessoas...

As diferenças, seja no campo acadêmico ou no financeiro, entre os estudantes da moradia estudantil e os "estudantes tradicionais" da UFRJ aparecem na fala dos próprios entrevistados:

[...] A Relações Internacionais na UFRJ exige um inglês meio avançado, que você precisava ter... Nível de proficiência. Eu nem sabia mesmo o que era nível de proficiência. Apesar de eu ter estudado quatro anos antes de entrar na faculdade... Quando eu cheguei as pessoas na faculdade tinham estudado doze ou nove. As pessoas tinham ido pro exterior. E muitas combinavam de ir para o exterior a cada férias da faculdade. Então, quando eu entrei, eu tive muita dificuldade com o inglês.

Os relatos de alguns dos estudantes inseridos no programa de moradia estudantil ainda indicam que há situações em que são alvos de preconceito e discriminação nas relações com os colegas e com o corpo docente:

[...] Me sinto até um pouco envergonhado assim quando vou falar... Moro no alojamento e olha como é que é, a gente não tem água às vezes, não tem luz, internet é muito complicado. Todo mundo acha que é um caos, assim... Quando 
falo no estágio, todo mundo fala 'nossa, meu deus, você mora lá? Deve ser muito ruim.' Uns acham que é orgia o tempo inteiro, né? é bem complicado...

[...] Tinha a aula, tudo era dado em inglês, debater questões, como a gente debate normalmente em português, debater em inglês, ler textos em inglês... E essa coisa foi complicada... quando eu falei que não sabia, que eu não podia falar inglês. $O$ professor simplesmente falou assim "vai fazer um cursinho aí fora pra você falar", aí eu falei "não tenho dinheiro", aí ele falou "não posso fazer nada, tranca a matéria". Mas só que eu tenho essa origem. Os outros ninguém vai ter essa origem... Porque quem no Brasil tem quatro anos de inglês? Vão ser de certa forma excludente.

Um dos estudantes, embora reconhecendo que sua situação de permanência foi em parte resolvida quando passou a residir na moradia estudantil, apontou as dificuldades enfrentadas por outro grupo de estudantes, o das pessoas com deficiência, que encontram diferentes tipos de barreiras para a permanência na universidade: "não vou colocar nem agora a questão pessoal, vou colocar a questão geral. Acessibilidade do alojamento. Cadeirante não tem como morar no alojamento estudantil, outros deficientes teriam também dificuldade..."

Os estudantes também apontam como dificuldade a defasagem entre o número de moradias estudantis disponíveis em relação ao número de estudantes e o tamanho da universidade: "E acho que a dificuldade maior é a falta de suporte pro tamanho da universidade. A gente tem três andares, com trinta apartamentos com três quartos. Sei lá, tem menos de 500 vagas. Enfim, a maior universidade da América Latina... Não dá.”

No relato de vários alunos ficou evidenciado que a escolha pela UFRJ foi em grande parte influenciada pelo conhecimento prévio da existência de programas de assistência estudantil. Nesse sentido, consideram que esses programas são um importante suporte para a realização do curso superior e quando perguntados sobre as facilidades para a permanência na universidade e realização do curso, apontaram os programas de moradia, alimentação e o apoio financeiro das bolsas:

[...] O que tá me colocando a possibilidade de me formar mesmo é poder morar na casa de estudante, é poder estar na UFRJ sem a despesa da moradia, do aluguel, e tem o transporte, né? Que leva a gente pra Praia Vermelha.

[...] Eu acho que a assistência estudantil é o que facilita a minha vida... $\mathrm{Na}$ verdade sem ela, eu realmente não teria muita possibilidade. Na UFF eu fiquei, porque como eu já trabalhava, eu tinha um dinheiro guardado, aí consegui ficar, 
fiquei seis meses... Talvez poderia ficaria mais um pouco... Mas eu já tava começando a pensar na possibilidade de trabalhar, vendo lugar pra poder trabalhar... Eu ia ter que trabalhar e estudar e isso seria meio difícil. Já na UFRJ não... Eu tenho lugar pra ficar, meu quarto, que diga-se de passagem não é nada que se mostre numa reportagem em nenhum outro lugar... É um quarto bom. E tem a bolsa, esse auxílio em dinheiro, e esse outro estagio que eu faço, então, isso tudo me proporciona uma qualidade bem legal pra eu ficar.

[...] O bandejão é um apoio bem legal. Eu acho também muito interessante a questão do auxílio que a gente recebe financeiro por estar no alojamento. Eu não sabia que tinha, pra mim... Quando entrei pensei que ou era o alojamento ou o auxílio em dinheiro. Então achei que esse auxílio dá uma ajuda bem legal, inclusive e principalmente com relação a alimentação.

O PNAES estabelece as 10 áreas onde as ações de assistência devem ser desenvolvidas ${ }^{25}$. Entretanto, há desconhecimento dessa abrangência pela maioria dos estudantes entrevistados. O fato de apenas um dos entrevistados ter citado o esporte e a necessidade de lazer como aspectos importantes para uma permanência de qualidade demonstra que, para o estudante que vem das classes populares, o principal problema refere-se à sua sobrevivência material, já que a realidade socioeconômica destes pode ser um impedimento para a realização do curso. Corrobora a situação de desigualdade não apenas econômica, mas também em outros níveis da vida para um segmento dos estudantes.

Em sua totalidade os estudantes associam de forma imediata à assistência estudantil os programas que envolvem o repasse direto de recursos financeiros Bolsa Auxílio, Auxílio Manutenção e Bolsa de Apoio a Permanência - o que indica ser este um recurso material importante para a manutenção das despesas básicas para a realização do curso. E, embora a formação acadêmica envolva questões de diversas ordens, para além do histórico "tripé” da assistência estudantil - moradia/alimentação/bolsa - a maioria dos estudantes entrevistados não associa questões como cultura, lazer, inclusão digital, entre outras, à política de permanência.

\footnotetext{
${ }^{25}$ As áreas previstas no PNAES são as seguintes: moradia estudantil; alimentação; transporte; atenção à saúde; inclusão digital; cultura; esporte; creche; apoio pedagógico; acesso, participação e aprendizagem de estudantes com deficiência, transtornos globais do desenvolvimento e altas habilidades e superdotação.
} 


\section{3. \\ O Olhar do Estudante sobre a Assistência Estudantil da UFRJ: o que se conhece?}

Que programas de assistência estudantil você conhece e quais deles você utiliza? Como você avalia estes programas? Em sua opinião os programas de assistência estudantil da UFRJ atende às necessidades dos estudantes para a permanência na universidade? Estas foram questões colocadas para os estudantes entrevistados para que pudéssemos identificar o nível de conhecimento dos mesmos sobre a assistência estudantil da UFRJ e sua avaliação sobre o alcance e a efetividade dos programas existentes.

Pelas respostas dos entrevistados percebemos que, a maioria considera como assistência estudantil de forma mais imediata os programas que envolvem a subsistência material. Dentre estes, os mais conhecidos são:

[...] Tem o alojamento, tem a bolsa... Eu não sei se aquele programa de monitorias também é, de pesquisa... Acho que só, né? Não, tem o riocard universitário...Ah, o bandejão...

[...] O benefício de alojamento, as bolsas... A bolsa... Como é o nome... A bolsa de apoio sem o alojamento. Eu esqueci o nome do benefício. É a bolsa que dá pro aluno que mora perto, mas tem dificuldade. Não é a bolsa do alojamento, mas é uma bolsa que serve pra ajuda.

[...] Bom, eu sei que tem o benefício moradia que é o alojamento. Tem uma galera que não consegue esse, e tem o auxílio estudantil que é 400 reais também por mês. No alojamento eles dão 400 reais por mês pra gente.

A totalidade dos estudantes entrevistados reconhece a moradia e as bolsas como programas de assistência estudantil. Alguns entrevistados também apontaram o "bandejão" como programa de assistência estudantil apesar da administração dos restaurantes universitários não estar no âmbito da Superintendência de Políticas Estudantis e sim sob a coordenação do Instituto de Nutrição. ${ }^{26}$

Dentre os entrevistados somente 2 fazem menção a programas que não visam diretamente à subsistência, como os de saúde e de apoio a eventos

${ }^{26}$ Esta questão já foi explicada em item anterior deste trabalho. 
acadêmicos, associando-os a uma melhor qualidade da permanência e da formação acadêmica:

[...] Tem a divisão de saúde. Eu conheço o serviço que a odontologia tá oferecendo, né? Tem o instituo de ginecologia que atende as alunas, né? $\mathrm{O}$ acompanhamento ginecológico e tal, saúde da mulher. Ah, e eu faço até uso, dentro da divisão de saúde, de outra unidade que é o IPUB.

[...] Hoje também parece que tem bolsa pra fazer eventos estudantis também... E uma coisa que eu tô gostando mesmo é essa autonomia que a Superest tá dando para os estudantes fazerem eventos sem estar com a necessidade de uma orientação de professor. Porque às vezes os estudantes têm outras demandas e aí eles vêem outras necessidades, outro tipo de eventos, outra forma de ver as coisas. Isso contribui pra criatividade.

O entrevistado ainda destaca a importância desse programa para a formação integral do estudante universitário:

[...] Eu acho que os anos mais produtivos da vida acadêmica é o ano que a gente tá na graduação. Acredito que isso é a parte mais produtiva, que você pode estar com maior criatividade. A gente tá realizando uma coisa, tá discutindo coisas legais. Aí tá aprendendo também a gestionar, como é que pode fazer com recursos.... Acho que essas coisas ajudam bastante.

Essa colocação reflete a diversidade de situações que os estudantes vivenciam no período em que estão na universidade e a expectativa de aprendizagem relacionada à formação, mas vivenciadas fora das salas de aula.

Ainda no que se refere à assistência estudantil deve-se ressaltar os benefícios voltados especificamente para a permanência dos estudantes oriundos de políticas de ação afirmativa.

A UFRJ implementou desde o ano de 2010 a política de ação afirmativa para ingresso nos cursos de graduação, com reserva de vagas para o ano de 2011 para pessoas que cursaram o ensino médio na rede pública de ensino. No ano de 2012 o Colegiado Superior decidiu aliar à reserva de vaga, também a concessão de auxílio financeiro para os estudantes ingressantes por esta política e criou uma modalidade de bolsa denominada Bolsa de Acesso e Permanência, destinada especificamente a este grupo de estudantes. Dentre os entrevistados, somente 2 fizeram referência a este programa, ainda que sem muita clareza sobre a denominação ou sobre a finalidades dessa bolsa: 
[...] Eu não sei exatamente qual o nome que se dá à bolsa, mas eu tenho dois colegas que entraram por cota de ensino público e recebem o auxílio moradia e o auxílio transporte.

[...] Teve aquela não sei que positivo, afirmativo, uma bolsa pra quem estudou o ensino médio em colégio público.

A partir dos relatos obtidos nas entrevistas, verificou-se que não há identificação ou conhecimento do conjunto dos programas e ações que compõem a assistência estudantil da UFRJ. O fato nos chamou a atenção principalmente por vir de estudantes que são usuários de um ou mais desses programas. A questão da informação como condição primordial para o alcance dos direitos, embora não seja objeto de estudo deste trabalho, merece análise mais detalhada.

\section{4 . \\ Avaliação dos Programas: o que pensam os estudantes?}

Os programas de assistência estudantil têm por finalidade apoiar os estudantes para a realização do curso superior minimizando os efeitos das desigualdades sociais para a formação universitária de estudantes de grupos populares.

$\mathrm{Na}$ maior parte, as avaliações dos estudantes destacam a situação de desigualdade social que caracteriza a educação superior e o papel que a assistência estudantil desempenha para a realização da graduação para uma parcela da população excluída do espaço universitário. Estas avaliações ficam evidenciadas nos seguintes depoimentos:

[...] O acesso à universidade ainda é bem elitizado. Aqui no Centro de Ciências Tecnológicas é absolutamente elitizado. Acho que a questão da cota por ensino público insere uma parte da população que realmente era exclusa, mas acho que esses auxílios vêm no sentido de tipo assim... Eu vou incentivar o aluno a permanecer na universidade, e buscar terminar a graduação. Porque entrar na graduação é um primeiro passo muito difícil. Permanecer nela e sair dela é um passo gigantesco. Então acho que esses auxílios têm fator diferencial nesse sentido. 
[...] eu acho que a proposta é excelente, tem que existir, mas ela ainda é muito mínima diante do nosso país e diante do próprio tamanho da universidade... Do respaldo que ela tem nacional e internacionalmente. E pela questão de dizer 'é a maior universidade da América Latina', então tenhamos condições pros nossos estudantes fazerem jus ao nome.

Quando perguntados sobre o que pensam acerca da assistência estudantil os depoimentos são diversos. Na maioria dos estudantes, a fala principal se baseia nos aspectos referentes aos direitos sociais e a sua efetividade enquanto política de permanência:

[...] Eu acho que é um programa absolutamente necessário. A gente vive num país com uma diferença de distribuição de renda absurda. Então os auxílios da assistência estudantil são necessário pra inserir a população... Pra que a gente tenha condições de fazer um bom curso de graduação, e poder ter um emprego melhor... Uma situação salarial melhor. Eu vejo isso com uma ação pra lá na frente ter uma distribuição de renda bem melhor. Não sei como vai ficar isso por questões culturais do nosso país. Mas eu acho que ainda é pouco.

[...] Não é ideal, as políticas, os programas não são ideais... Não na sua efetividade, talvez na sua elaboração formal, legal, aparentemente são eficientes, mas efetivamente eles não são, aparentam ser, mas não são.

O acesso à educação superior amplia as oportunidades sociais, econômicas e políticas possibilitando o rompimento com um padrão de desigualdade social que alcança na atualidade níveis excessivamente elevados. Os depoimentos acima indicam que alguns estudantes têm consciência dessas diferenças sociais e econômicas que caracterizam alguns grupos, além da expectativa de que a formação superior possibilite uma mobilidade social e redução da condição de desigualdade social. As falas evidenciam, ainda, o conhecimento dos estudantes acerca do papel que a assistência estudantil tem nesse processo de formação.

As análises feitas por alguns estudantes indicam conhecimento sobre a situação dos estudantes pobres, que têm que enfrentar dificuldades diversas para a realização e conclusão do curso e de como as condições concretas da vida destes estudantes pode levá-los a interromper ou atrasar a formação universitária:

[...] Tem estudantes que simplesmente abandonam a universidade porque não tem condições de conseguir viver. Tem gente que vai trabalhar, e vai faltando à faculdade pra tentar sobreviver, mesmo ganhando a bolsa de assistência. Porque 
ele não consegue sobreviver com aquilo, aí aquilo interfere nele na aula, e isso interfere na qualidade dele como aluno e etc.

O estudante aponta, ainda, para o fato de que o conhecimento teórico produzido na universidade acerca da realidade social não estar servindo para concretizar mudanças nas condições de desigualdade que impedem a inclusão social de estudantes pobres.

[...] A UFRJ tem economistas, tem contadores, tem juristas e... essas pessoas têm como saber qual é a realidade econômica do Rio de Janeiro, como o estudante consegue sobreviver, tem inúmeras pesquisas aí que falam sobre isso... Então acho que a universidade tinha que dar prioridade ao estudante.

Ainda no que concerne à avaliação dos programas de permanência, os entrevistados falaram sobre a existência de recursos financeiros para a assistência estudantil e expressaram suas avaliações sobre a insuficiência do montante destinado para a UFRJ em relação ao número de estudantes que precisaria ser atendido:

[...] Tem muita gente mesmo que não recebe. Inclusive eu estive aqui no Consuni, lá pra 2010 assim, e teve um professor aí que fez uma pesquisa e descobriu que quem realmente precisava de assistência estudantil na UFRJ mesmo era $30 \%$ da UFRJ, e parece que a bolsa ela não abrange $30 \%$ dos alunos. Quantitativamente parece ser muito grande... Só que a UFRJ é grande... E aí, por exemplo, o que a UFRJ recebe de dinheiro pra assistência estudantil é muito maior do que as outras recebem. Só que na UFRJ tem uma quantidade muito maior e também está vivendo no Rio de Janeiro, uma das cidades mais caras que existem no mundo.

[...] Olha, eu acredito que não atenda a todos que precisam porque a UFRJ tem um número enorme de estudantes, há um grupo muito grande, que não tem acesso, que não consegue o acesso ao atendimento... Então eu acho que a proposta é excelente, tem que existir, mas ela ainda é muito mínima diante do nosso país e diante do próprio tamanho da universidade...

Os relatos acima apontam para a necessidade de ampliação quantitativa dos programas de assistência estudantil existentes na universidade diante do crescimento do número de estudantes que tem demandado algum tipo de apoio para a sua permanência. 
Os entrevistados apontaram, ainda, para a questão da qualidade das condições de permanência oferecidas aos estudantes. Neste aspecto da qualidade dos serviços todos os entrevistados foram enfáticos nas críticas, apesar de reconhecer a importância da assistência estudantil para os estudantes de baixa renda:

[...] Eu acho que esses programas... Pro meu ideal de faculdade, acho que eles são essenciais. Porque eu acho que a ideia de uma universidade é agregar conhecimento com o povo, com a sociedade de um modo geral. E nós temos muitas pessoas que não tem acesso à informação, então como você alcança essas pessoas? Eu sou uma delas, eu consegui fazer por conta disso, então eu acho que é muito importante esses programas de auxílio, todos eles são muito importantes. São precários, eu confesso, eu acho que são precários sim, entendeu? Mas eu acho que são muito importantes. E mesmo sendo precário, ele consegue ajudar de alguma forma. Uma parcela, obviamente.

[...] Eu acho que devia ter outros bandejões e tal. Eu acho que dá pra sobreviver, mas não atende. Não atende as necessidades... Tipo, é melhor ter do que não ter. $\mathrm{Eu}$ acho que é um programa que ele... Ele tenta ser abrangente na quantidade, mas ele é limitado na qualidade.

[...] O auxílio financeiro da bolsa é uma coisa mínima pra você ter sua manutenção. Alimentação, contando muito com o bandejão, e o transporte pra certos casos, assim... E uma coisa que é meio complicado, às vezes dependendo do curso a gente não tem tanta facilidade pra achar bolsas. E realmente é um auxílio manutenção e ponto. Alimente-se e transporte-se. Quando dá.

As falas indicam que há necessidade de melhoria na qualidade de serviços de alimentação e transporte que são básicos, porém essenciais para a permanência dos estudantes na universidade e também apontam para a defasagem nos valores das bolsas em relação às despesas para a permanência na universidade.

Entretanto, uma assistência estudantil de qualidade requer maior investimento em programas necessários à manutenção mínima, como moradia, alimentação e transporte, mas também em ações de saúde física e mental, lazer, esporte, cultura numa perspectiva de formação acadêmica e de cidadania ampliadas, para além da formação técnica e profissional.

A existência de uma política nacional de assistência estudantil aliada à política de educação, a nosso ver, é condição imprescindível para a consolidação do processo de democratização da educação superior que está em curso. A implementação dessa política é uma medida já há muito tempo adiada, mas que se 
torna imperiosa para que o direito à educação superior seja garantido às pessoas de todos os grupos sociais.

A expectativa é de que essa democratização possibilite uma maior presença de pessoas das classes populares e de grupos desiguais num espaço ocupado prioritariamente pelas classes dominantes do país, contribuindo para a reversão do quadro de desigualdade educacional que tem sido constante no Brasil. Para tanto, é preciso que o Estado e a própria universidade dêem prioridade na implementação de políticas públicas que viabilize igualdade de condições para a permanência de todos os estudantes, independente de sua origem social.

A necessidade de uma política de assistência estudantil abrangente encontra respaldo na análise feita por Sposati (2011) em relação às políticas sociais focalizadas. A inexistência de políticas que atendam às necessidades sociais universais mantém a condição da desigualdade entre os cidadãos no usufruto dos direitos sociais, com a conversão das políticas sociais de direitos em políticas de atendimento às condições mínimas para a sobrevivência.

Ainda no que se referem à avaliação dos programas, as falas dos entrevistados se focaram mais nas críticas em relação às condições do alojamento, principalmente pelo fato se serem estudantes inseridos no programa de moradia, que convivem diariamente com os problemas e deficiências existentes na residência estudantil:

[...] Ah, o alojamento? Isso aí... O alojamento é horroroso. Aquilo lá, desculpe a expressão, parece um presídio. É um apartamento com três quartos... Cara, é horroroso. A fiação é horrorosa, a água vem com ferrugem, os canos são... Tem cano de amianto ainda. Cara, aquele prédio necessita de uma reforma... Não digo nem demolição não, porque se demolir não vão construir um novo. Mas eu acho que ele necessita de uma reforma urgente. Aquilo tá horroroso. O pessoal que fica lá, fica porque realmente precisa. Porque qualquer pessoa com a mínima condição de sair de lá, sai

[...] A estrutura física do alojamento, por exemplo, não beneficia alguém a morar lá. A gente convive constantemente com barata, rato, lacraia, falta de luz, água, internet... Quando chove, alaga o hall do alojamento, então é complicado. Não só o hall, no feminino alaga os corredores mesmo, dos andares.

[...] É um prédio muito antigo, que não tem reformas. Então acho que assim, você acaba tendo uma qualidade de vida menor, uma saúde mais prejudicada, uma saúde tanto física quanto mental mesmo. Então eu acho que tem uma ajuda, mas não é o suficiente... Em alguns momentos a gente se sente prejudicado mesmo.... Não é o mínimo necessário pra você levar um curso de graduação que às vezes é pesado e tal, com a pressão às vezes da sua família passando por problemas,... E 
você mesmo passando por problemas, entendeu? Então acho que não é o necessário. Poderia ser muito melhor.

São relatos que expressam uma realidade a qual um grupo significativo de estudantes está submetido para conseguir realizar seus cursos. As falas indicam que as condições tanto materiais quanto subjetivas do alojamento não possibilitam uma permanência com qualidade o que, não raro, provocam situações de adoecimento físico e psicológico.

[...] É um prédio muito antigo, que não tem reformas. Então acho que assim, você acaba tendo uma qualidade de vida menor, uma saúde mais prejudicada, uma saúde tanto física quanto mental mesmo.

[...] a casa tem uma série de coisas pra fazer, uma série de manutenções. Falta água sempre, falta luz... Tem uma manutenção precarizada, muito precarizada, que não se resolve, a gente tá aguardando que se resolvam esses problemas mais estruturais... Da água, da internet que não tem, de uns bebedouros que existem nos andares e não funcionam... Tem muita coisa na casa pra ser resolvida, pra ser trabalhada, pra amadurecer enquanto qualidade de vida, bem-estar, enfim, o que é básico pra você ter o mínimo de condições pra se concentrar.

Alguns estudantes ainda avaliaram a assistência estudantil numa perspectiva mais abrangente ao sinalizar para a carência ou inexistência de outros aspectos que consideram importantes para uma permanência de qualidade, como, por exemplo, a atenção à saúde.

[...] Quando a gente precisa de um médico a gente não tem isso. Eu já fui com um amigo uma vez pra Bonsucesso, e eu passei uma noite lá, no dia 7 de setembro de $2011 \ldots$ a gente não precisa só de um lugar pra ficar, comer e dormir. A gente precisa de um auxílio de saúde, a gente precisa de outras coisas, entendeu? E aí quando eu falo saúde, eu tô falando de auxílio psicológico também, porque eu acho super necessário... Eu já fiz um acompanhamento psicológico na Praia Vermelha, mas a demanda é muito maior. Quer dizer, há uma demanda e não supre o que tem.

[...] A gente não tem atendimento aberto no HU, então você aguarda numa fila que eu nem sei que tamanho está... Eu preciso de uma especialidade tal e até hoje não consegui.... Já faz uns seis meses isso. E aí, assim, onde eu consigo acesso eu fui muito bem atendida. No Instituto de Ginecologia, o acompanhamento lá tem todos os exames, inclusive se a pessoa faz uso de anticoncepcional, as médicas dão, e preservativo... No atendimento do Instituto de Psiquiatria também é muito bom... O atendimento... Os médicos são bons.

[...] Eu acho que seria uma boa um benefício relacionado à saúde... Porque os estudantes, todos eles têm problemas às vezes de saúde mesmo, psicológico ou 
qualquer outra coisa do tipo... Hoje em dia, eu hoje no alojamento, se eu passo mal, eu não sou atendido no HU. Eu vou ter que ir pro Paulino Werneck, ou pra UPA, ou alguma coisa do tipo. Então eu acho que um benefício concreto, uma ajuda pros estudantes em relação à saúde, que tá deixando a desejar. Devia haver sim um benefício relacionado à saúde.

Apesar da UFRJ ter várias unidades de saúde, como o Hospital Universitário, o Instituto de Psiquiatria, a Faculdade de Odontologia, entre outros, as condições de atendimento à saúde do estudante ainda é uma questão que precisa ser discutida e encaminhada pelas diversas instâncias envolvidas. Já houve diversas tentativas de estabelecer uma rotina para o atendimento dos estudantes, principalmente os que são moradores do alojamento já que, em geral, estes estudantes, oriundos de locais distantes da universidade, não podem utilizar a saúde pública dos seus locais de moradia de origem e também não tem condições para custear planos privados de saúde. Algumas dessas iniciativas tiveram êxito através de protocolos de atendimento firmados entre a Divisão de Saúde da SuperEst e as unidades de saúde da universidade, como é o caso do Instituto de Ginecologia e o Instituto de Psiquiatria. Entretanto, casos de emergência ou de tratamento ambulatorial continuam tendo atendimento insuficiente no âmbito dos recursos da área de saúde da própria universidade.

A totalidade dos estudantes fez referência ao valor das bolsas com ponderações relativas às diversas despesas para a permanência na universidade:

[...] Eu acredito que o benefício moradia então podia ser maior, porque o benefício moradia não é só pra comprar comida e coisas do tipo. Você compra comida, às vezes até uma roupa nova, ou então produto de limpeza, aquilo ali serve... O nome é bolsa permanência, então o valor que tem que ser dado é pra você permanecer ali. E a permanência sua na faculdade não é só pra comida. É comida, é xerox, é livro, até o seu produto de limpeza.

[...] Então, eu acho que eles são deficientes por questão de valor, do próprio valor da bolsa, quer dizer... Tá em 400 reais agora o que eu ganho. Eu acho que seria um pouco apertado se eu não tivesse o outro estágio. Eu ficaria realmente, sabe... Não daria pra comprar meus livros, ficaria com xerox, minha alimentação... E a questão da diversão que eu falei, que às vezes eu saio daqui... isso prejudicaria muito... Eu viveria no limite.

Para conseguir suprir outras despesas da formação universitária como comprar livros, tirar xerox, participar de seminários ou necessárias à complementação da formação profissional como a realização de cursos de línguas 
estrangeiras, por exemplo, a maioria dos entrevistados precisa realizar outra atividade remunerada, seja ela acadêmica ou profissional, para complementar o valor recebido com a bolsa.

Há, ainda, situações em que os estudantes precisam utilizar parte do dinheiro que recebem com a bolsa para ajudar a família, conforme relatado abaixo:

[...] Então... Se você for pensar, 400 reais é menos que um salário mínimo. Por mais que a gente não tenha uma família e tal... Alguns de nós sustentam a família lá fora, entendeu? Tipo, já aconteceu de eu ajudar meus pais. Ontem mesmo eu depositei 150 reais na conta da minha mãe. Tem gente que deposita praticamente tudo. Pega o seu dinheirinho, vai lá e deposita, manda pros pais e tal.

Os depoimentos dos entrevistados demonstram que, mesmo após o ingresso numa universidade pública, estudantes pobres enfrentam condições desiguais para a realização dos cursos. Esses estudantes estão mais sujeitos a enfrentar obstáculos e dificuldades que poderão interferir na qualidade ou na continuidade de sua graduação, principalmente quando ingressam em cursos considerados elitizados.

Conforme apontado por Schwartzman (2010) os estudantes que não tiveram uma boa formação acadêmica nas etapas iniciais da escolarização e que optam por cursos em que são altos os níveis de exigência tendem a abandonar a universidade nos primeiros anos. Para o autor, um dos principais problemas da educação superior refere-se à ausência de atendimento diferenciado aos estudantes dos diversos grupos sociais que, historicamente, encontram-se em posição desigual na várias esferas da sociedade e que tem reflexos na manutenção da condição de desigualdade também na escolha dos cursos e das carreiras profissionais.

Embora não seja objeto do presente estudo avaliar o desempenho acadêmico dos entrevistados deve-se ressaltar que dos 8 entrevistados, 5 deles (63\%) tiveram no final do $2^{\circ}$. semestre de 2012 coeficiente de rendimento entre 7,3 e 9,2; os outros 3 (37\%) tiveram rendimento entre 3,1 e $5,0 .{ }^{27}$ Os dados

${ }^{27}$ Os dados referentes ao desempenho acadêmico dos estudantes entrevistados foram obtidos em consulta ao histórico escolar, posteriormente à realização das entrevistas. 
indicam que os alunos entrevistados, oriundos das classes populares e beneficiários dos programas de assistência estudantil, vêm mantendo um rendimento acadêmico consistente.

Em relação ao desempenho acadêmico, há que se destacar a relevância dos programas de acompanhamento acadêmico e apoio pedagógico para os estudantes inseridos nos programas de assistência estudantil e as implicações desse apoio na trajetória universitária. Embora exista na UFRJ uma resolução que institui que todos os cursos tenham uma COAA/Comissão de Orientação e Acompanhamento Acadêmico, o papel que muitas delas desempenham está muito aquém das finalidades para as quais foram criadas.

O relato de um dos entrevistados é bastante claro quanto ao que os estudantes esperam e desejam nesta questão:

[...] Uma sugestão que eu acho que seria importantíssima, que eu não percebi aqui na UFRJ, que é o trabalho da COAA. A COAA, que é uma coordenação de orientação acadêmica, acho que ela tinha que ter o trabalho dela um pouco mais apurado, que ela auxiliaria muito a assistência estudantil. A COAA, ao meu ver, ela parece somente pra punir...Mas acho que seria uma questão de orientar, principalmente pra alunos do alojamento, eu acho que tinha que ter uma COAA específica. Uma COAA que chegasse junto e perguntasse, encontrasse com o aluno a cada bimestre ou trimestre pra saber como tá o andamento, o que tá acontecendo na sua vida, se tá com problema familiar, como é que tá o andamento, se as coisas estão melhorando, se estão piorando... A gente te dá residência, você tem a bolsa, mas você não tá conseguindo levar? O que tá acontecendo? Então a COAA iria... Acho que ela seria essencial, é um trabalho de formiguinha, mas acho que seria essencial pra qualificar muito o trabalho da universidade. E aí iria orientar...

A avaliação sobre a importância de um efetivo trabalho de orientação e acompanhamento acadêmico por parte das COAAs demonstra que os entrevistados têm conhecimento e consciência de que a principal finalidade da assistência estudantil é a de prover os recursos necessários para que os estudantes tenham um bom desempenho acadêmico.

Nesse sentido, uma efetiva e eficaz política de permanência requer a articulação entre as unidades de ensino e a instância responsável pela coordenação e administração dos programas de assistência estudantil de forma a não se perder de vista a concepção acadêmica que deve pautar as ações de assistência estudantil. 
A importância da articulação das ações de assistência estudantil com o processo de formação acadêmica constitui-se, conforme apontado por Oliveira (1997), em medida fundamental para a alteração do quadro de fragmentação e descontinuidade que tem caracterizado a assistência estudantil na UFRJ. A concepção dessas ações como parte do projeto de formação educacional possibilita uma mudança no status que a assistência estudantil teve até então na universidade pública.

Pode-se afirmar que a assistência estudantil da UFRJ está em processo de reformulação, mas embora seja fundamental para a manutenção do estudante na universidade ainda é insuficiente para atender às reais demandas dos grupos que vivem em condição de desigualdade social, como os estudantes das classes populares e das diversas etnias e raças.

Os estudantes entrevistados, quando solicitados a falarem o que pensam sobre a assistência estudantil, externaram, sem meias palavras, suas opiniões e impressões acerca dos programas desenvolvidos na UFRJ, com avaliações sobre os serviços existentes e sobre as atuais condições para a permanência dos estudantes na universidade.

As falas não deixam dúvidas sobre a importância dos programas de assistência estudantil, principalmente a moradia e as bolsas, para suas permanências como universitários de origem popular e para o bom desempenho acadêmico no decorrer do período da graduação.

Em sua totalidade, os estudantes demonstraram maior conhecimento dos programas de apoio financeiro embora com ressalvas quanto ao valor das bolsas diante das necessidades dos estudantes durante a sua formação e das condições econômicas de suas famílias. Apontaram, também, para a necessidade de ampliação dos programas tanto do ponto de vista quantitativo, para o atendimento de um maior número de estudantes, quanto da abrangência das ações, com referências a programas de assistência à saúde e de acompanhamento pedagógico.

Pelo fato de serem moradores da residência estudantil os entrevistados foram bastante enfáticos na avaliação das precárias condições em que se encontra o prédio da residência. As falas revelam que a vivência como "morador de casa de estudante" é uma experiência complexa, permeada por momentos difíceis e contraditórios e que transcende, por vezes, a compreensão de quem está do lado de fora. Os depoimentos indicam, ainda, uma compreensão da realidade social que 
caracteriza a sociedade brasileira e a universidade como expressão dessa realidade. 


\section{Considerações Finais}

A Educação superior e a universidade pública brasileira vivem um período de grandes desafios, perspectivas e possibilidades. Apesar de alguns avanços, o Brasil ainda é um país em que as desigualdades sociais são enormes e ainda persiste um processo de exclusão de acesso aos bens e serviços para grande parte da população. O acesso à educação, em especial a educação superior pública, ainda é uma realidade bastante distante para muitos jovens.

A universidade pública esteve, desde a sua gênese, voltada para uma pequena parcela da sociedade brasileira, para os setores produtivos e para os filhos das elites econômicas, estando dela excluídos aqueles oriundos das classes populares e dos grupos que vivem historicamente em condições de desigualdade social, tais como, negros e indígenas.

Essa realidade começa a se alterar com as políticas para a democratização do acesso à educação superior que vem sendo implementadas no Brasil há uma década e também devido à ação de movimentos sociais que desde as décadas de 1980 e 1990 vem exigindo direitos e o seu reconhecimento enquanto grupos sociais. Desta forma, organizações voltadas às questões raciais e de gênero, entre outras, passam a reivindicar seus direitos e, mais especificamente no campo da educação superior, as organizações ligadas ao movimento negro reivindicam o direito a estudar nas universidades. O Pré Vestibular para Negros e Carentes PVNC foi, neste caso, o movimento social protagonista nesta luta pelo acesso e permanência de estudantes negros e pobres nas universidades brasileiras.

Embora conscientes de que essas transformações se inserem num projeto maior de reforma do Estado, para atender as exigências do padrão de acumulação definido pela lógica neoliberal, não se pode desconsiderar que, tais políticas também estão possibilitando um maior acesso à universidade de pessoas oriundas de escolas públicas, de negros, de indígenas e pertencentes às camadas mais pobres da sociedade.

O REUNI está promovendo uma expansão quantitativa do acesso, com o aumento progressivo do número de vagas de graduação, inclusive em cursos 
noturnos. Entretanto, essa expansão não tem sido acompanhada das necessárias alterações das condições materiais concretas - recursos financeiros, de pessoal, espaço físico - para manutenção da qualidade da formação acadêmica.

Também merece atenção o fato de que, sendo um de seus objetivos a igualdade de oportunidades para os estudantes em situação de desigualdade socioeconômica, o REUNI prevê a ampliação das políticas de inclusão social e de assistência estudantil. Entretanto, esta é uma perspectiva que tem encontrado enormes desafios para se consolidar como uma efetiva política de permanência dada à insuficiência de recursos financeiros, humanos e de estrutura física das universidades.

É neste aspecto que se situa o foco deste trabalho. A concepção de que a assistência estudantil configura-se como mecanismo fundamental para a permanência dos estudantes das classes populares e dos grupos desiguais, na perspectiva de que o acesso e a permanência são dimensões que devem ser tratadas de forma indissociável quando se trata de democratização da educação superior.

Neste sentido, buscou-se conhecer o papel da assistência estudantil na trajetória universitária e na formação dos estudantes de graduação da UFRJ que são oriundos das classes econômica e socialmente desfavorecidas.

Os programas de assistência estudantil na UFRJ datam da década de 70, mas tiveram seu desenvolvimento realizado de forma segmentada, focalizada e desarticulado do projeto de formação acadêmica dos estudantes. Além disso, não esteve entre as prioridades nas diversas gestões administrativas da universidade, que não consideraram sua relevância para a permanência dos estudantes.

A mudança no perfil dos estudantes, decorrentes das políticas de ampliação do acesso, e a necessidade de elevação das taxas de conclusão e redução dos índices de retenção e evasão, colocaram a assistência estudantil sob novo ângulo dentro da política de educação superior.

A despeito de sua funcionalidade ao cumprimento das metas do REUNI, não há duvidas de que a assistência estudantil também cumpre importante papel para a permanência e efetivação da formação superior em especial, para estudantes oriundos dos grupos sociais que se encontram em condição de desigualdade. E a sua efetivação, ainda como política de governo, mas que se deseja de Estado, é resultante também das reivindicações de segmentos sociais e 
da comunidade acadêmica que a entendem como fundamental para a permanência dos estudantes nos cursos de graduação.

Entretanto, a assistência estudantil voltada para a permanência de alunos em situação de desigualdade, seja socioeconômica, racial ou educacional, ainda provoca polêmicas nas universidades.

$\mathrm{Na}$ realidade brasileira a desigualdade social é aceita como natural e romper com esse padrão exige mudanças de paradigmas na implementação de novas políticas sociais. No caso da educação superior, essa alteração teve um importante incentivo com a aprovação da lei que cria a política de ação afirmativa para o ingresso nas universidades, fruto da pressão dos grupos sociais organizados, em especial o movimento negro.

$\mathrm{O}$ reconhecimento da existência de desigualdade no direito à educação superior foi assumido pelo Estado com os diversos dispositivos legais para ampliação e democratização do acesso à universidade aos grupos socialmente diferenciados. No entanto, essa condição de desigualdade se mantém para os estudantes desses grupos mesmo após a inserção na universidade.

Assim, as políticas de ampliação do acesso à universidade devem ser acompanhadas de outras medidas que possibilitem aos estudantes em situação de desigualdade condições para uma trajetória universitária e uma formação acadêmica bem sucedida.

O Plano Nacional de Assistência Estudantil - PNAES ao considerar como prioridade atender aos estudantes em condição de desigualdade social, em particular os oriundos da rede pública de ensino e com renda familiar per capita de até 1,5 salários mínimos, se constitui em desdobramento necessário à democratização proposta pelo Estado e é "a sustentação à adoção de políticas afirmativas" (MEC, 2007).

Na pesquisa realizada, ficou evidenciado que, em geral, os estudantes com estas características têm sido atendidos nos programas de assistência estudantil desenvolvidos na UFRJ. Constatou-se, também, que as dificuldades encontradas por parcela dos estudantes pertencentes às classes populares em seu percurso universitário são inúmeras.

Outros aspectos identificados com a realização da pesquisa merecem destaque: 
- os estudantes entrevistados, oriundos de famílias de baixa renda e, em sua quase totalidade, sem formação universitária, consideraram, na escolha de seus cursos, suas aptidões, afinidades e vocações e não somente as possibilidades de inserção no mercado de trabalho;

- a maioria dos entrevistados identifica como principais programas de assistência estudantil na UFRJ a moradia e as bolsas de auxílio financeiro. Esses programas foram apontados por todos os entrevistados como fundamentais para a permanência e realização dos cursos. No entanto, ressaltam a insuficiência dos valores das bolsas para atendimento a todas as necessidades decorrentes da vida universitária;

- os estudantes também apontaram a necessidade de ampliação da abrangência dos programas, principalmente do ponto de vista quantitativo. Todos relataram conhecer pessoas que enfrentam dificuldades e abandonam a universidade por não conseguirem se inserir num dos programas existentes;

- a percepção da condição de desigualdade que vivenciam alguns estudantes para sua inserção e permanência na universidade e uma concepção ampliada da assistência estudantil também foram aspectos relevantes nos relatos dos entrevistados.

O fato dos estudantes apontarem como necessidades para uma permanência de qualidade a existência de programas de saúde, lazer, esporte e acompanhamento pedagógico indica que, pela trajetória acadêmica, perpassam questões diversas que podem impedir ou dificultar a conclusão da graduação.

A realização da pesquisa indicou, ainda, que, a despeito dos problemas e das dificuldades para a sua consolidação como uma política institucional, os programas de assistência estudantil na UFRJ são apoios fundamentais para a permanência dos estudantes.

$\mathrm{O}$ ingresso de pessoas provenientes dos grupos populares e desiguais na UFRJ tem se tornado uma realidade cada vez mais concreta. Nesse contexto, a ampliação e a consolidação das ações de assistência estudantil numa efetiva política de permanência são desafios que se colocam para a concretização da inclusão social pela via da educação superior.

Considerando-se que a marca característica de formação da UFRJ foi sua ocupação pelas classes alta e média-alta da sociedade e o modo como historicamente ocorreu a formulação das políticas públicas no Brasil, marcada por 
embates e disputas em torno de interesses contrários e diferentes projetos de sociedade, tem-se claro que a construção e consolidação de uma Política de assistência estudantil não se fará sem dificuldades e sem disputas em torno de diferentes concepções de universidade.

Trazer à tona a discussão sobre as desigualdades sociais, econômicas, raciais, de gênero, num campo conhecido pela reprodução dessas desigualdades, a educação superior pública, é apenas o primeiro passo para que a universidade pública se torne um espaço mais diverso, mais plural e menos desigual. 


\section{5 \\ Referências Bibliográficas}

ALVES, J. M. A assistência estudantil no âmbito da política de educação superior pública. In: Serviço Social em Revista, v.5, n.1, p.1-9, 2009. Disponível em: <http://www.ssrevista.uel.br/c-v5n1.htm> Acesso em: 20 jan. 2012.

BARBOSA M. L.; SANTA`ANNA M. J. G. As classes populares e a valorização da educação no Brasil. Seminário Nacional Governança Urbana e Desenvolvimento Metropolitano. UFRN. Natal. 2010. Disponível em: <http://www.cchla.ufrn.br/seminariogovernanca/cdrom/ST9_Maria_Maria.pdf.>. Acesso em: 17 abr. 2013.

BARROS, R. P.; HENRIQUES, R.; MENDONÇA, R. Desigualdade e Pobreza no Brasil: retrato de uma estabilidade inaceitável. Rio de Janeiro: IPEA, no. 800, 2001.

BENEVIDES, M.V. Democracia de Iguais mas Diferentes. In: BORBA, A.; FARIA, N.; GODINHO, T. (Org.) Mulher e Política - Gênero e Feminismo nos Partido dos Trabalhadores. São Paulo: Ed. Fundação Perseu Abramo, 1998.

BRASIL. Decreto $\mathbf{n}^{\mathbf{0}} \mathbf{7 2 3 4}$, de 19 de julho de 2010. Dispõe sobre o Programa Nacional de Assistência Estudantil. Poder Executivo. Brasília, DF, 20 de julho de 2010 .

Decreto no 6096, de 24 de abril de 2007. Institui o Programa de Apoio a Planos de Reestruturação e Expansão das Universidades Federais - REUNI. Diário Oficial da União. Poder Executivo. Brasília. DF, 24 de abril de 2007.

Lei $n^{\circ} 12.711$, de 29 de Agosto de 2012. Dispõe sobre o ingresso nas universidades federais e nas instituições federais de ensino técnico de nível médio e dá outras providências. Diário Oficial da União. Poder Executivo. Brasília. DF, 30 de Agosto de 2012.

Ministério da Educação e Cultura. Instituto Nacional de Estudos e Pesquisas Educacionais (INEP). Censo da Educação Superior 2010. Divulgação dos principais resultados, Outubro de 2011. Brasília, DF: MEC, INEP, 2011. Disponível em: <http://portal.inep.gov.br/superior-censosuperior-sinopse.> Acesso em: 16 jun. 2012.

CARVAlHO, J. M. de. A Cidadania no Brasil - O longo caminho. Rio de Janeiro: Civilização Brasileira, 2a ${ }^{\mathrm{a}}$. Ed., 2002

CHAUÍ, M. Escritos sobre a Universidade. São Paulo: Editora UNESP, 2001. 
COUTINHO, C. N. Gramsci: um estudo sobre seu pensamento político. Rio de Janeiro: Civilização Brasileira, 1999.

Notas sobre cidadania e modernidade. Revista Praia Vermelha. Rio de Janeiro: UFRJ, v.I, n.1, set/1994.

DAGNINO, E. Sociedade Civil, Participação e Cidadania: De que estamos falando? In: MATO, D. (Coord.). Politicas de ciudadania y sociedad civil em tiempos de globalización. Caracas. FACES, Universidad Central de Venezuela, 2004.

DEMO, P. Cidadania Tutelada e Cidadania Assistida. Campinas: Ed. Autores Associados, 1995.

Exclusão Social - Novas e Velhas Formas. Rio de Janeiro: Debates Sociais. CBCISS, 2001.

DOURADO, L. F. Reforma do Estado e as Políticas para a Educação Superior no Brasil nos anos 90. Educ. Soc., Campinas, v. 23, n. 80 p. 234-252, set. 2002 Disponível em: <http://www.cedes.unicamp.br>. Acesso em: 10 mar. 2013.

ESCOREL, S. Vidas ao Léu: trajetórias de exclusão social. Rio de Janeiro: Ed. Fiocruz, 1999.

FÁVERO, M. L. Universidade e Poder: análise crítica/fundamentos históricos: 1930-45. Rio de Janeiro: Achiamé, 1980.

. Universidade no Brasil: das origens à construção. Rio de Janeiro:

Editora UFRJ, 2010.

FONAPRACE. Revista Comemorativa 25 anos: histórias, memórias e múltiplos olhares. Fórum Nacional de Pró-Reitores de Assuntos Comunitários e Estudantis/ ANDIFES (Org.). UFU. Uberlândia. 2012

GIL, A. C. Métodos e Técnicas de Pesquisa Social. São Paulo: Ed. Atlas, 1978

GOHN, M. da G. Educação, Trabalho e Lutas Sociais. In: GENTILI, P.; FRIGOTTO, G. (Orgs.). A Cidadania Negada: políticas de exclusão na educação e no trabalho. S. Paulo: Cortez; Buenos Aires: CLACSO, 2011.

GOHN, M. da G. Movimentos Sociais na Contemporaneidade. In: Revista Brasileira de Educação, v. 16, n. 47, 2011. Disponível em: <http://www.scielo.br>. Acesso em: 20 jun. 2012.

GOMES, J. B. B. A recepção do Instituto da Ação Afirmativa no Direito Constitucional Brasileiro. In: SANTOS, R.; LOBATO, F. (Orgs.). Ações Afirmativas - Políticas Públicas contra as desigualdades raciais. Rio de Janeiro: DP\&A. 2004. 
HENRIQUES, R. Desigualdade Racial no Brasil: evolução das condições de vida na década de 90. Rio de Janeiro: IPEA, 2001.

HENRIQUES, R. et al. A estabilidade inaceitável: desigualdade e pobreza no Brasil. In: HENRIQUES, R. (Org.). Desigualdade e Pobreza no Brasil. Rio de Janeiro: IPEA, 2000.

HERINGER, R.; PAULA, M. (Orgs.) Caminhos Convergentes: Estado e Sociedade na Superação das desigualdades raciais no Brasil. Rio de Janeiro: Fundação Heinrich Boll, ActionAid, 2009.

KOWALSKI, A.V. Os (des)caminhos da política de assistência estudantil e o desafio na garantia de direitos. $179 \mathrm{f}$. Tese (Doutoramento em Serviço Social) Programa de Pós-Graduação em Serviço Social, Pontifícia Universidade Católica do Rio Grande do Sul/PUC-RS, Porto Alegre. 2012.

LIMA, K. Expansão da educação superior brasileira na primeira metade do novo século In: ALMEIDA, N. L.T; PEREIRA, L. D. (Orgs.) Serviço Social e Educação. FORTI, V.; GUERRA, Y. - Coordenadoras da Série. Rio de Janeiro: Lumen Juris, 2012.

MARShalL, T. H. Cidadania, Classe Social e Status. Rio de Janeiro: Zahar, 1967.

MENEZES, S. C. Assistência Estudantil na Educação Superior Pública: O programa de Bolsas implementado pela Universidade federal do Rio de Janeiro. 137 f. Dissertação (Mestrado em Serviço Social) Programa de Pós Graduação em Serviço Social. Pontifícia Universidade Católica/PUC-Rio. Rio de Janeiro. 2012.

MINAYO, M. C. (Org.). Pesquisa social: Teoria, Método e Criatividade. Petrópolis: Ed. Vozes, 2001.

MOEHLECKE, S. Ação Afirmativa: História e Debates no Brasil. In Cadernos de Pesquisa, n.117, 2002. p. 197-217.

NETTO, J. P. Desigualdade, Pobreza e Serviço Social. In: Revista Em Pauta, n.19, Rio de Janeiro: UERJ, 2007.

NEVES, L. M. W.; FERNANDES, R. R. Política neoliberal e educação superior. In: NEVES, L. M. W. (Org.). O empresariamento da educação: novos contornos do ensino superior no Brasil dos anos 1990. São Paulo: Xamã, 2002, p. 21-40.

OLIVEIRA, A. J. B. A Casa de Minerva: Entre a Ilha e o Palácio. O discurso sobre os lugares como metáfora da identidade institucional. 352 f. Tese (Doutoramento em Memória Social). Programa de Pós Graduação em Memória Social. Universidade Federal do Estado do Rio de Janeiro/UNIRIO, Rio de Janeiro, 2011. 
OLIVEIRA, A. J. B. Da implantação à institucionalização: consolidando a Superintendência Geral de Políticas Estudantis. In: Reunião da Regional Sudeste do Fórum Nacional de Pró-Reitores de Assuntos Comunitários e Estudantis, 2012, Viçosa. ANAIS. Viçosa: UFV, 2012.

OLIVEIRA, E. A. A Assistência ao estudante no espaço universitário. 177 f., Dissertação (Mestrado em Serviço Social). Programa de Pós-Graduação em Serviço Social. Universidade Federal do Rio de Janeiro/UFRJ, Rio de Janeiro, 1997.

OLIVEIRA, F. O que é Formação para cidadania? Entrevista realizada em $1999 . \quad$ Disponível em: <http://www.polis.org.br/publicacoes/artigos/entrevchico.html >. Acesso em: abr. de 2010 .

PAIVA, A. M. de R. Direitos, desigualdade e acesso à universidade. In: O Social em Questão, n. 23, Rio de Janeiro: PUC-Rio, 2010.

PAOLI, M. C.; TELLES, V. da S. Direitos Sociais: conflitos e negociações no Brasil contemporâneo. In: ALVAREZ, S. E. ; DAGNINO, E. ; ESCOBAR, A. (Orgs.). Cultura e Política nos movimentos sociais latino-americanos. Belo Horizonte: UFRMG, 2000.

PEREIRA, L. D. Educação e Serviço Social. Do Confessionalismo ao Empresariamento da Formação Profissional. São Paulo: Xamã, 2008.

PEREIRA, P. A. P. Política Social: temas e questões. São Paulo: Cortez, 2011.

PEREIRA, T. I.; SILVA, L. F. S. C. As políticas públicas do ensino superior no governo Lula: expansão ou democratização? In: Revista Debates. Porto Alegre, v.4, n.2, p. 10-31, jul.-dez. 2010. Disponível em: <www.seer.ufrgs.br/debates/article/download>. Acesso em: 03 abr. 2013.

POCHMANN, M. Brasil o país dos desiguais. Le Monde Diplomatique, Ano 1, no. 3 out. de 2007. Disponível em: <http://diplomatique.uol.com.br/artigo.php?id=30>. Acesso em: 10 abr. 2013.

POCHMANN, M. et.al. (Orgs.). Os ricos no Brasil. Atlas da exclusão social no Brasil, v. 3. 2a . ed. São Paulo: Cortez, 2005.

ROCHA, S. Os "novos" programas de transferência de renda: impactos possíveis sobre a desigualdade no Brasil. In: HENRIQUES, R. (Org.). Desigualdade e Pobreza no Brasil. Rio de Janeiro: IPEA, 2001.

SALVADOR, A. C. Ação Afirmativa no Ensino Superior: um estudo da Política de Inserção de alunos oriundos de pré-vestibulares para negros e carentes, prévestibulares comunitários e lideranças comunitárias implementadas na PUC-RJ. In: O Social em Questão, n.15, Rio de Janeiro: PUC-Rio, 2006. 
SALVADOR, A. C. Ação Afirmativa na PUC-Rio: a inserção de alunos pobres e negros. Rio de Janeiro: Ed. PUC-Rio, 2011.

SANTOS, A. R. Metodologia Cientifica: a construção do conhecimento. Rio de Janeiro: Lamparina, 2007.

SANTOS, B. S. A universidade do século XXI - Para uma reforma democrática e emancipatória da universidade. São Paulo: Ed. Cortez, 2005.

Renovar a Teoria Crítica e Reinventar a Emancipação Social. São Paulo: Boitempo, 2007.

SAVIANI, D. O plano de desenvolvimento da educação: análise do projeto do MEC, Educ. Soc., Campinas, v. 28, n. 100 - Especial, p. 1231-1255, out. 2007 Disponível em: <http://www.cedes.unicamp.br>. Acesso em: 28 jan. 2013.

SILVA JUNIOR, J. R. Novas Faces da Educação Superior no Brasil. 2a . ed.rev. São Paulo: Ed. Cortez. Bragança Paulista, SP. USF-IFAN, 2001.

Pragmatismo e Populismo na Educação Superior nos governos FHC e Lula. São Paulo: Xamã, 2005.

SOTERO, E. C. Políticas Afirmativas de Incentivo à Permanência na Universidade: Conexões entre Brasil e Estados Unidos. In: VIEIRA, V. R.; JOHNSON, J. (Orgs.). Retratos e Espelhos: Raça e Etnicidade no Brasil e nos Estados Unidos. São Paulo: FEA/USP, 2009, v. 1, p. 343-358.

SOUZA FILHO, R. Estado, Sociedade e Política Social no Brasil - dilemas da cooperação. In: O Social em Questão, n. 5, Rio de Janeiro: PUC-Rio, 1999.

VIANA, M. L. T. Em torno do conceito de política social: notas introdutórias. 2002. Disponível em: <http://www.enap.org.br/downloads/ec43ea4fMarialucia1>. Acesso em: 04 mar. 2013.

VIEIRA, A. L. C; VIEIRA, J. J. Dilemas da inclusão e entraves à permanência: por uma reflexão multidimensional das políticas de ação afirmativa no Brasil. In: O Social em Questão, n. 23. Rio de Janeiro: PUC-Rio. Departamento de Serviço Social. 2010.

WANDERLEY, L. E. O que é universidade? São Paulo: Ed. Brasiliense, 2003. 


\section{6 \\ Apêndices}

\section{1.}

\section{Roteiro de Entrevistas}

Sexo:

Cor:

Idade:

Estado Civil:

Curso:

Período:

Horário:

Turno:

Local de Origem Familiar (Bairro/Cidade/Estado):

Referência atual de moradia:

Escolaridade dos Pais: Mãe: Pai:

Profissão dos Pais: Mãe: Pai:

Renda Familiar:

01 - Você trabalha ou já trabalhou?

Função (ões):

02 - Escola em que estudou a maior parte do tempo: Pública ( ) Particular ( ) 03 - Fez curso preparatório para ingresso na universidade? Não（） Sim（） Qual:

04 - O que levou a escolha do curso?

05 - O que levou a escolha da UFRJ?

06 - Ao escolher a UFRJ você considerou/conhecia os programas de assistência estudantil da UFRJ?

07 - Quem mais na sua família possui ou está fazendo curso superior?

08 - Quais as maiores despesas para a realização de seu curso?

09 - Como você faz para pagar essas despesas?

10 - Quais as dificuldades/facilidades que você tem encontrado para realizar seu curso?

11 - Como você tem solucionado estas dificuldades?

12 - Já pensou em desistir do curso?

Por quê?

13 - Quais os programas de assistência estudantil da UFRJ que você conhece?

14 - Quais os programas de assistência estudantil da UFRJ que você utiliza?

15 - O que você acha dos programas de assistência estudantil que você utiliza? 
16 - Você acha que os programas de assistência estudantil da UFRJ atendem as necessidades dos estudantes? Por quê?

17 - Diga quais outros programas de assistência estudantil você considera que seriam importantes para a permanência dos estudantes na UFRJ.

18 - Você conhece os programas de assistência estudantil de outras universidades? Qual (is)?

19 - Diga o que você pensa sobre os programas de assistência estudantil oferecidos pela UFRJ. 


\section{2.}

\section{Termo de Consentimento Livre e Esclarecido}

Este documento procura dar a você informações e pedir sua participação na pesquisa de Mestrado do Departamento de Serviço Social da Pontifica Universidade Católica PUC-RJ, intitulada "Os programas de Assistência Estudantil da UFRJ e seu papel para a permanência dos estudantes de graduação" a ser conduzida pela mestranda Rosélia Pinheiro de Magalhães

A pesquisa tem como objetivo identificar de que maneira os programas de assistência estudantil praticados na UFRJ têm atuado na trajetória dos estudantes de graduação, moradores da residência estudantil. Essas informações serão obtidas através de uma entrevista semi-estruturada, com duração de, aproximadamente, 40 minutos e deverá ser gravada, caso haja permissão do entrevistado.

Esta pesquisa não oferece qualquer risco para a sua relação social, profissional, familiar ou sua segurança. Mas como benefício poderá contribuir para uma nova configuração da assistência estudantil desenvolvida na UFRJ, com a implementação de novas ações, mais adequadas à realidade socioeconômica dos estudantes.

Esclareço que as informações obtidas nesta pesquisa serão confidenciais e asseguro sigilo sobre seus dados pessoais. Ao término da pesquisa, você terá livre acesso aos seus resultados.

Informo que uma cópia deste documento, devidamente assinada, ficará com o participante da pesquisa e outra com o pesquisador.

Como responsável pela pesquisa, estarei disponível para esclarecer suas dúvidas sobre o projeto e sua participação no seguinte telefone: (21) 25981623 e no endereço eletrônico: roselia.magalhaes@yahoo.com.br

Declaro ter entendido os objetivos, condições e benefícios da pesquisa e concordo em participar.

Rio de Janeiro,

de 2013.

(participante)

(pesquisador) 


\section{Anexos}

7.1.

Anexo1 - Matérias de jornais

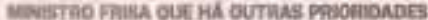

Para Mercadantes pesa também o fato de que ba vutras prioridaden, no leque que vai das crecthe a pós-ymutusclica. Pum ele, o dinheiro destinat a uma sepsundai edichas anual do Enem seri thatl hem empregendo em projetos como o que innturit ganustir a alfaberizarclos de todos os abunos ute 06 a anos de latade, ou o de asslatenteta eshudatuitil pare cotistas em niniversidades lede. raik ambos com inicie previsto em 2013.

- Nós tranos, neste momento a necestidade de um novo exame - affrmou Mercadante ao

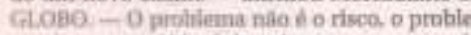
ma hi o custo. Nós dobrariamos os custos do Finem. Durmtan milhồea.. Quantas creches eu conutrua? Nilo wo creches nós ternor necessida. Ae brutal de recunos na Educacto. Aquilo que a grate plé evtá tirando de alpuim outro liggar:

Comparável a uma operaça de guerra. Fnem moblitizsa mals de 560 mil proflssionain, em 1.615 minuieipion, no ano passado. O níme io de inscritos chegne a a 7 , milhoes, des quats a.r milhiee fiaerim o teste

Indasado ne enterrou a ideles da segundia edil cla antal. o minkatro respondey

- Ná nós nle ahandanamos. Qual é u prioridade do linem? Silo os alunos coneluintes. E os conctainres, que estâo chegando a quase dois milhoes, se formam av fim do ino. Entala, a niassa pitoridade è esse Enem que nós frcenos nessin data. De qualquer furma, continsiaremos estodando alternativen.

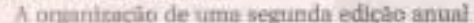
do Enem fot attopeladu pelo nucessito de fillhus sas tribs primeiras edicoes do exame: o furto e. adiamento da provic, em 2009; nerros de im. presslio has foltina de respoutus e num lote de

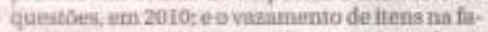
se de pee teite do ejame de 2011, quando as pernantas foram submetidas a um grupo de słunos para verificar smu grau de dificuldade, A lalta de um hanco com mitiot nùmero de ques: lóes pobatratas também em apoatadi por Hauddud como um phsticule h realizaçấe de mainr ncimero die ediçoes do Enem.

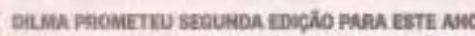
Oerau de canvenctmento do MEC acerca da ne-

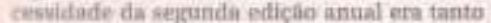
quin a probrla Dilma prometeus adotíla ja em 2017 A prnvidente-flilou sobre o lssumso em faneise the 2012, aa vépen da saida de Heddad: - Trme de luar por isso. Nos melhoramos, ve moir malhorar alnda mais e vamos ter depolk, no and que vem, ditas edipees, lsso em conourtinincia com o miniutro, ate por augestáo do minlatw - declarou Dilma a fornallstas após salesidade en contemoracilo à masca de um milhalo die boleme do ProUni (Pragrama Universílate para Todew), ato que marrou a despedi an e servitu de homenagem a Hiddad.

Merradante tom evitade comemorar prabli camentr o exito ner diltimo Enem, Pela primeitar vez, nầ houve vatamentos, netn ertos de itipresaso ou failhen que comprometessem o came. 1 le tem se limitado a ologiar a equlpe do Instituto Nacional de Estudos e Pesquisas Edocncionutu (Inep), orgato do Mric responsável pria gruva.

Aie poryue nindiu enta em andamento o greenchitmento de vartas em unlveraldales federais pelo statema de Selechlis Unificada (Sisu) bisuado exchastyamente nas notau do Enem. H

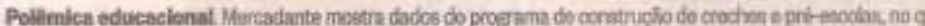

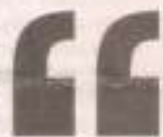

"Não temos, neste momento, a necessidade de novo exame. 0 problema năo é o risco, 0 problema é o custo. Nós dobrariamos os custos do Enem. Duzentos milhōes.. Quantas creches eu construo? Não só creches, nós temos uma necessidade brutal de recursos na Educaçâo. Aquilo que a gente pōe, está tirando de algum outro lugar"

"A prioridade hoje é a assistência estudantil. Porque estamos colocando pobres na universidade, que văo ficar um bom periodo de sua vida estudando. Nós temos que dar garantia a esses jovens de que possam permanecer estudando"

Aloizio Mertadante

Minintro dr Ediseselac

"Tem de lutar por isso. Nós melhoramos, vamos melhorar ainda mais e vamos ter depois, no ano que vem, duas ediçōes, isso em concordância com o ministro (Haddad), até por sugestão do ministro" Dilma Rousaer, em janeiro de 2012 faita divuigura cosrecto das trdapebes a qu tá provisto para fevereins.

- O Bnem fot bera melizada, acho quevel few grinder trobalho. For um exito ent ierm opereçso et logigiotica, de coidendo, atençia Para o ministro, portanto, o probletna mais de ordem operucional, jé que a pas ria demonatrado que é capazde neulizar a fa. Ele lembes também que, allèm do or aberto ao pubtico om gernl, o Inep pro anualmente o Enem para presidilíiles ano passado, preciaou aplicar uma ten prova para uma estudante excluida por voco, apos ser confundida com outra per pante que havia pestado imagtrns de dent sula, o que é proibida.

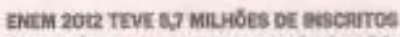

Agarrado ao angumenta econonica, Merr. te é enfítico ao defender outras priorid com énfase no atendinuento a cotintas err versidades federais e nil educacio bíticit

- Do meu ponto de visti. a prioridade a asskistência estudantill. Porque notsestamn locando pobres ne univeraldade, que viln um bom periodo da sai vida exrudanda. N mov que dar garantia a ouses joveni de qui sam permanecer estudando. Intäo, ale bolsa-estudo, precinamos fazter rentiun mondia e turoria, apoio pedagógico par permanecerem. Ternos um grande desaffit boststema de cotas - tiseve.

Cotistas de hatas renda gque se marricul em cursos como Medícina e Odontologin grade curricular tem mais de clnop horas las diarias, ganharila bolsa de 25.400 por O minintro diá ênfase, tambêm, ao char

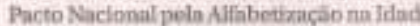
ta. que articutara esforyos dos governos mi pris, entaduair e federai para assegarar $q$ dos os alunos aprendam a let e escrover. de nocón de matemsitica, at os 8 anos. de nocoes de matensitica, unte os a no 39 ano do ensino fundamental.
- Nắn adianta eu pensar o Enem se $\mathrm{e}$ estou ulfabetivando he a criança nilo sub escrevet, nâs sabe as primeinis cuntas. $\mathrm{C}$. que ela val set desenvolver parn poder par um din do Finem? Elo onsinométio? Trent

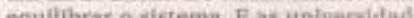

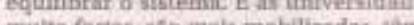
cspacidade de pressấa. Ea tenilência maj

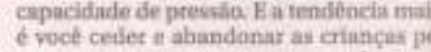
porque munca vi uma criença pobse aq Branhita protratande, nem um pal de netr dolas. Thmos que imanter o equilibrio arch tarifo - diuse o miniatro,

Sesundo ale, o corrumente do Macs rum leiglado a educachlo bisicn, caia fatin mut

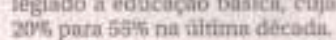

- Näb podemos so pensar no tinern et - Nä́ podern.

o Enem dezo12 teve 5,7 milhóes de ine A taxa de insericito foi pame pos 1.7 milhitio gerando uma arrecadaclo de $7561,5 \mathrm{mi}$ Alunes in exeolus pablicas tem inuncin.

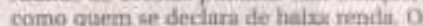

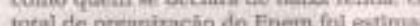

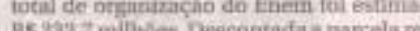
BS.

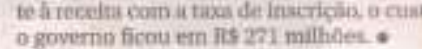




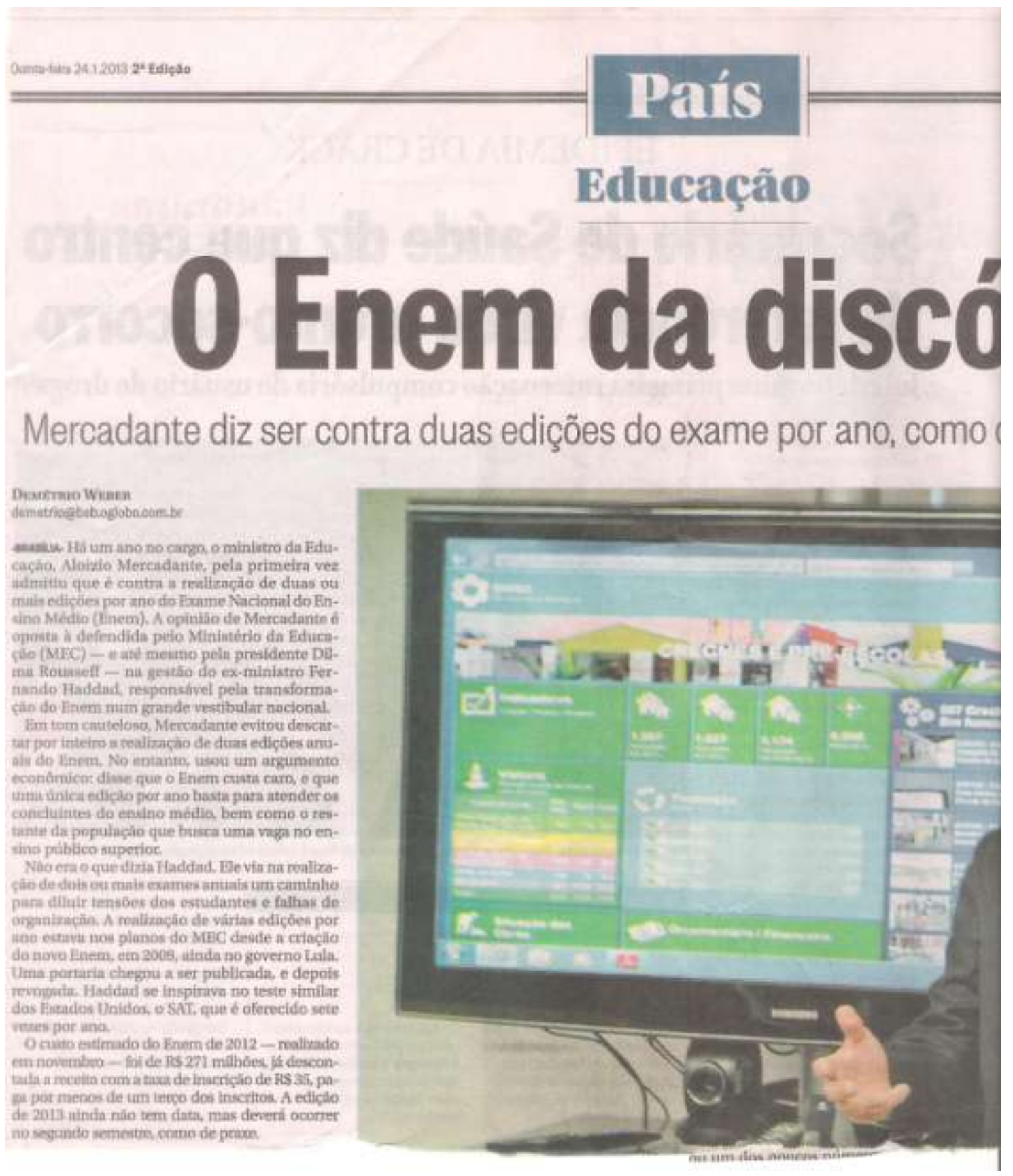




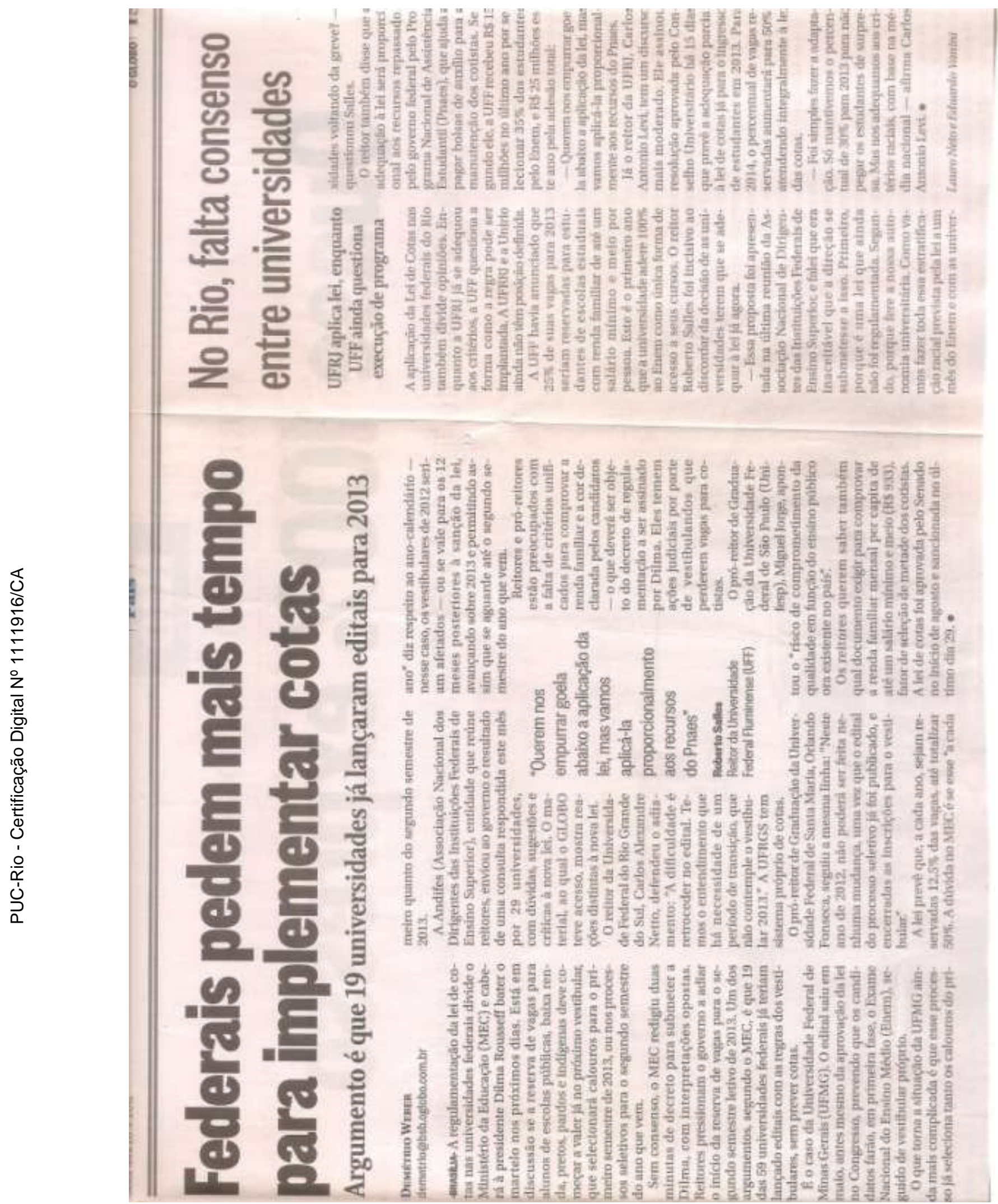




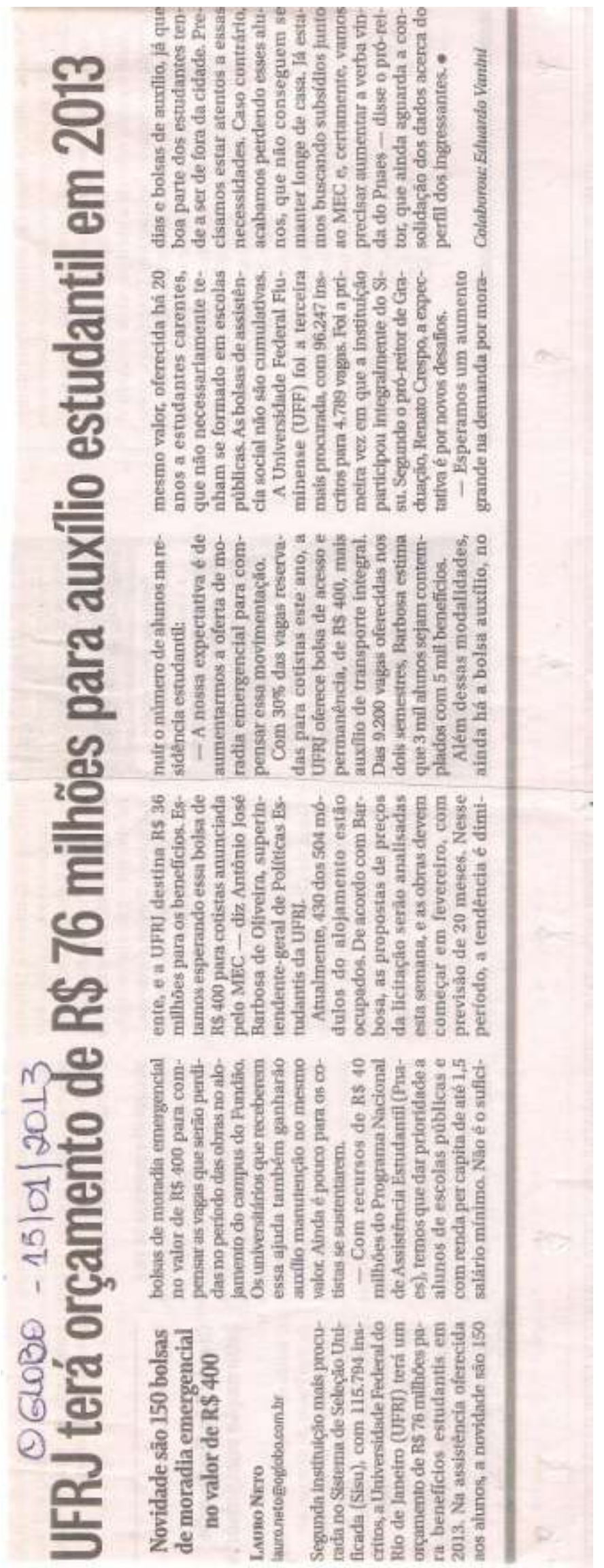


7.2.

Anexo 2 - Serviço de Assistência e Orientação ao Estudante da UFRJ - Projeto de Implantação
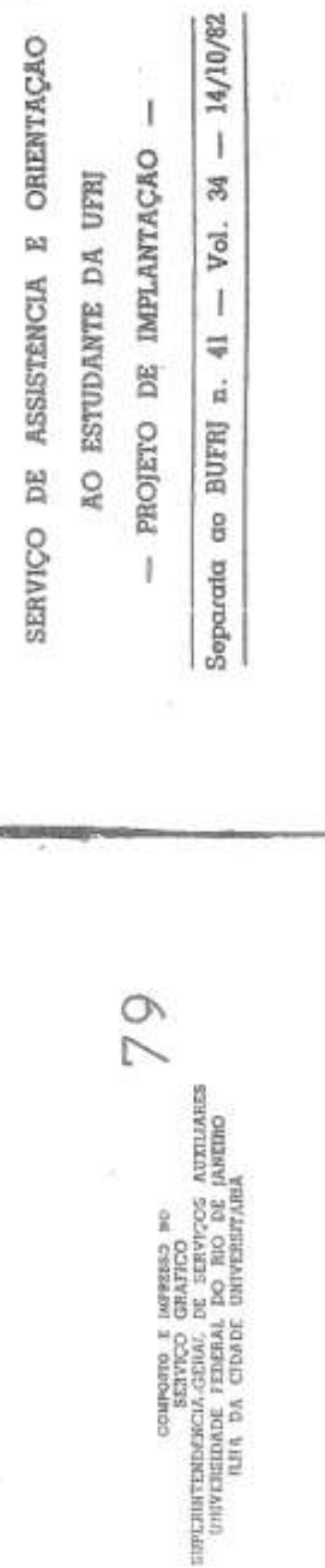


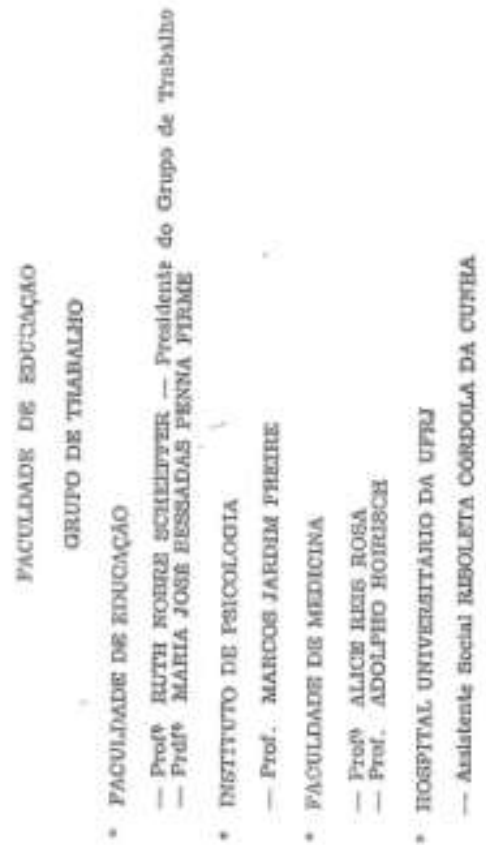

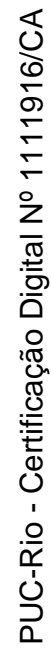

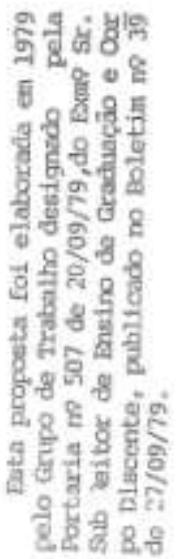




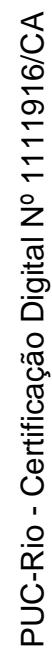

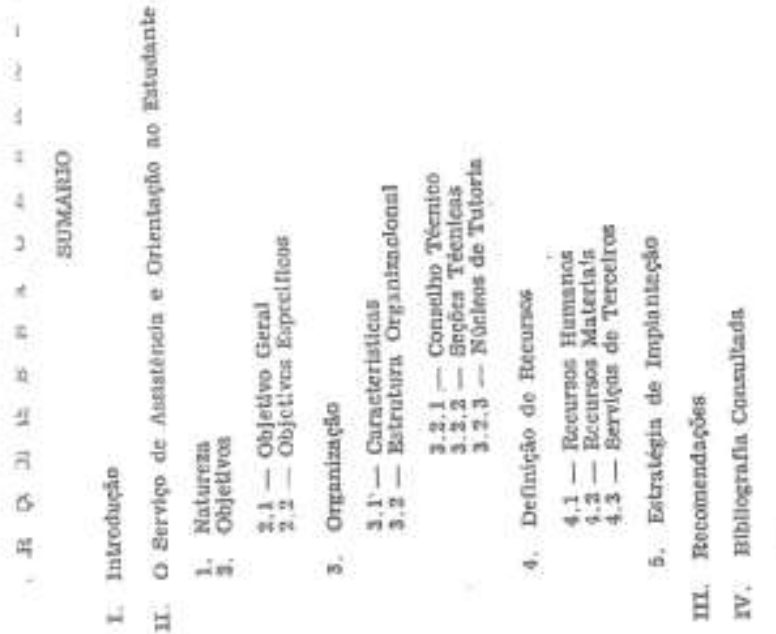



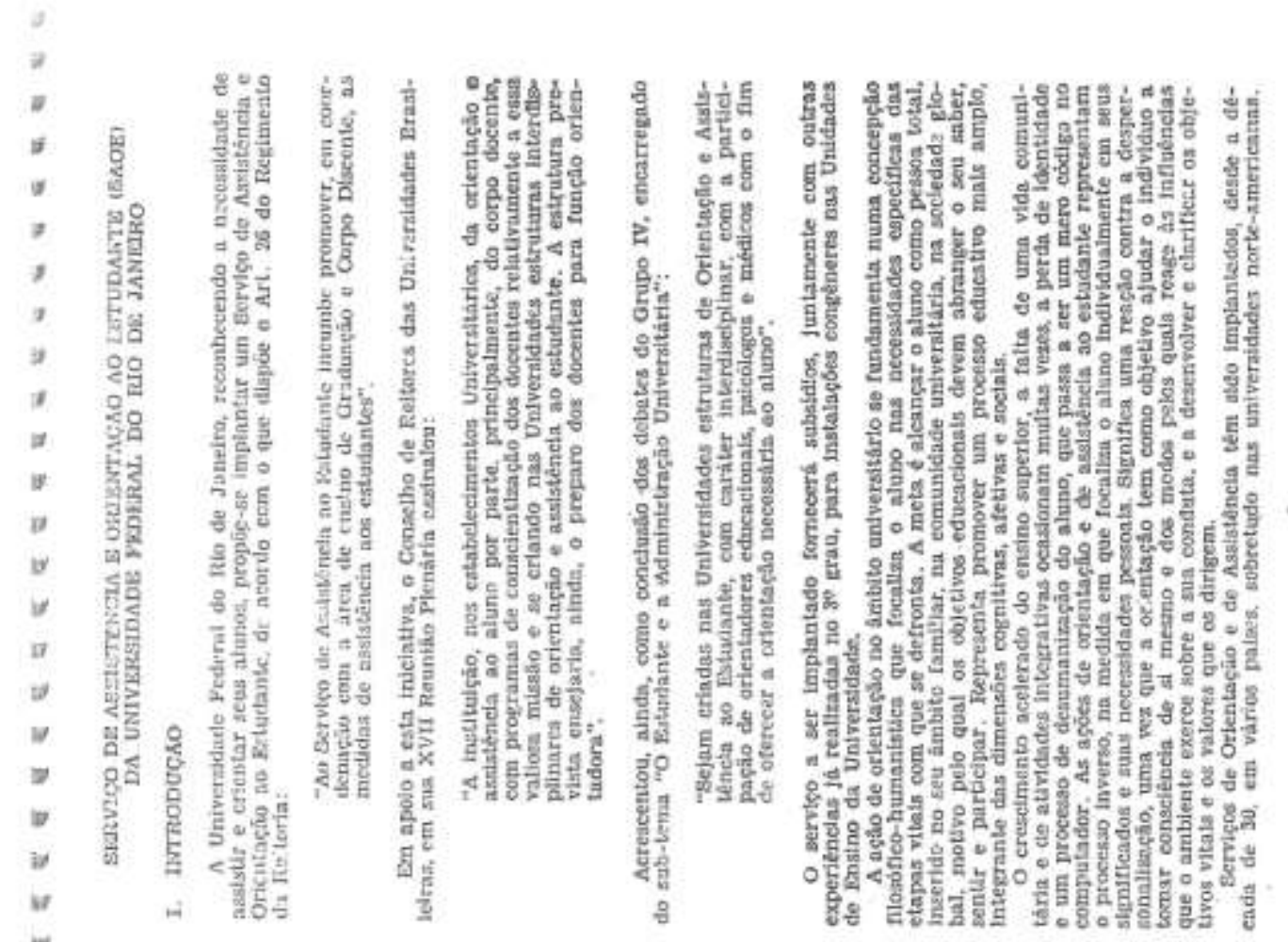

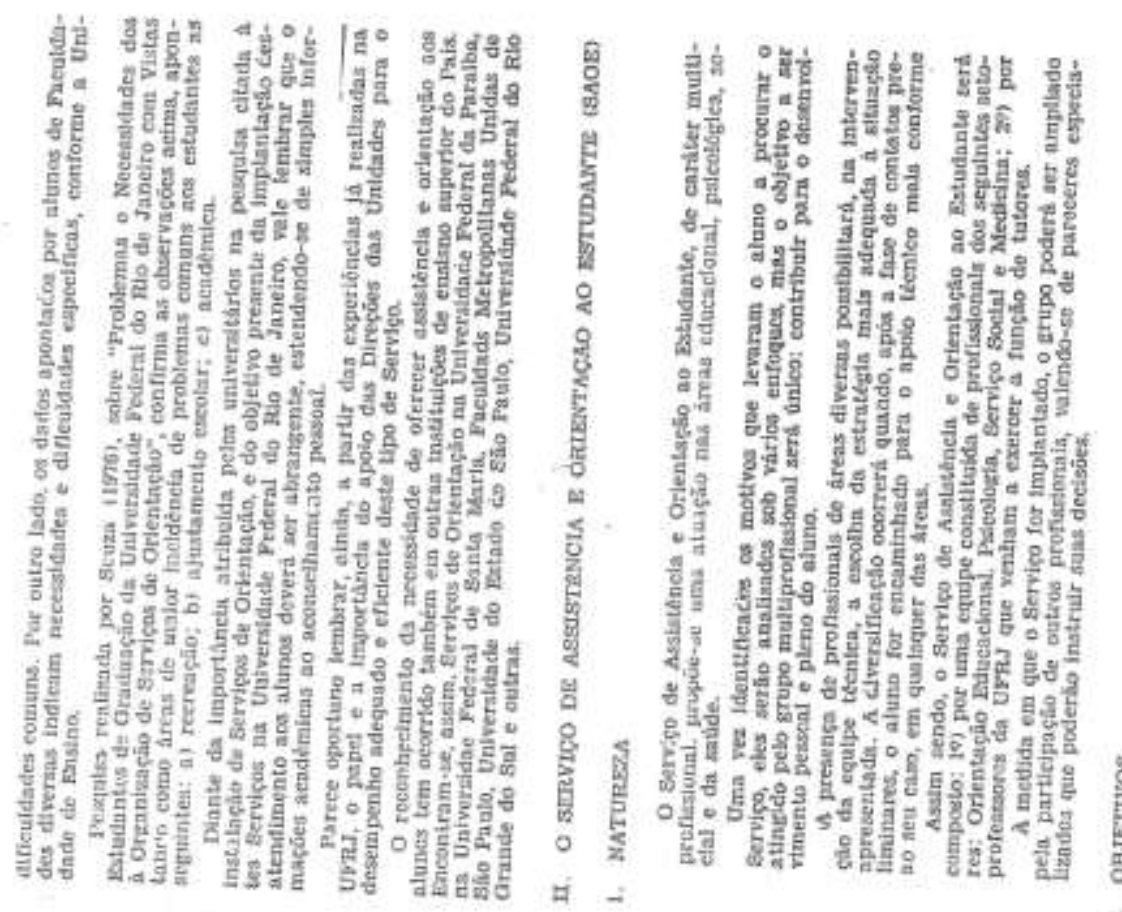

8 8 s

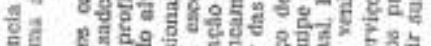

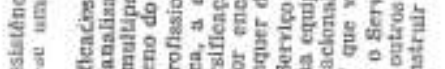
新 政

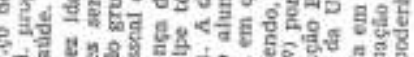
5

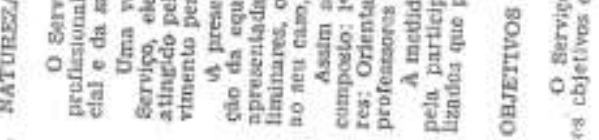

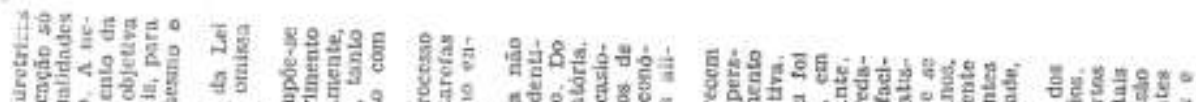

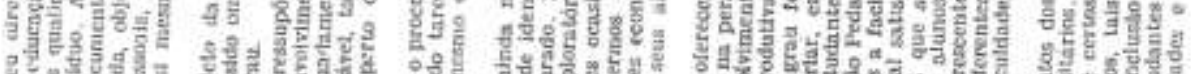

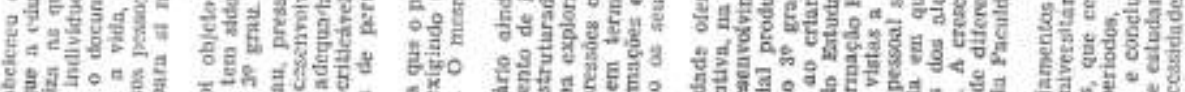

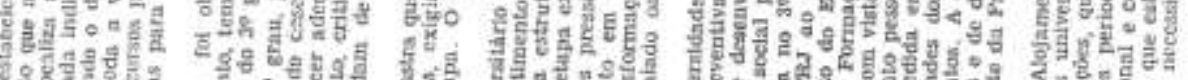

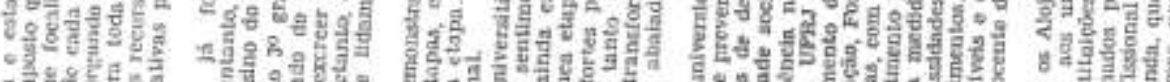

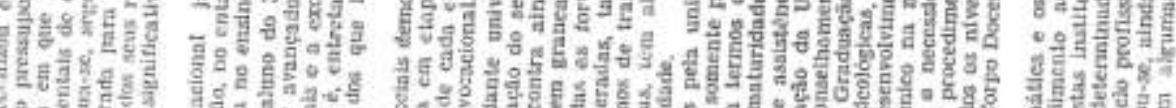
Eris

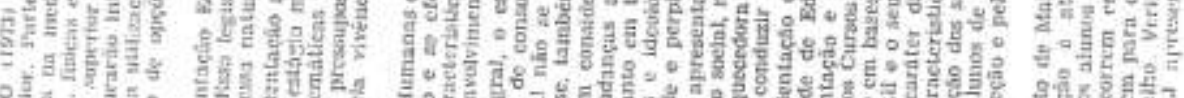

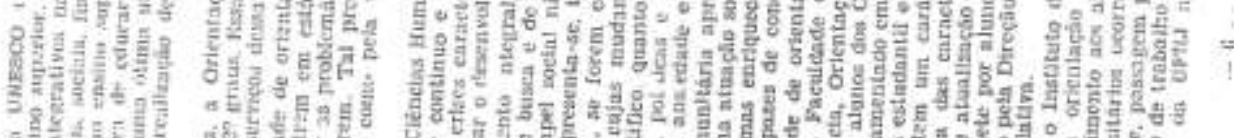

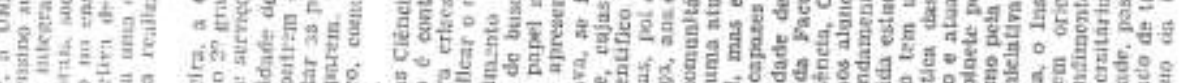

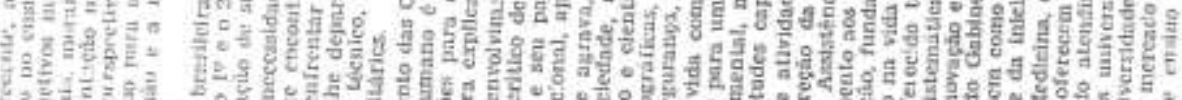
43 3 3.0.

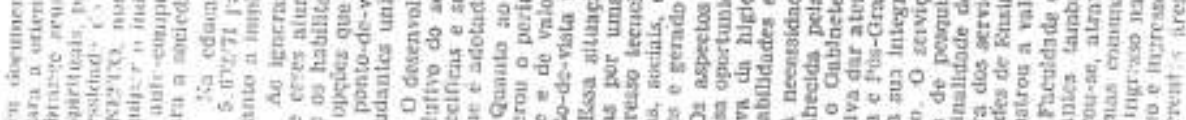

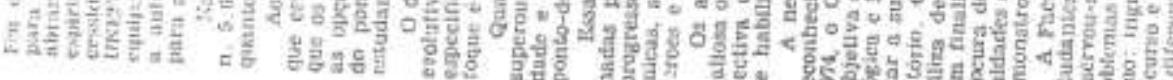




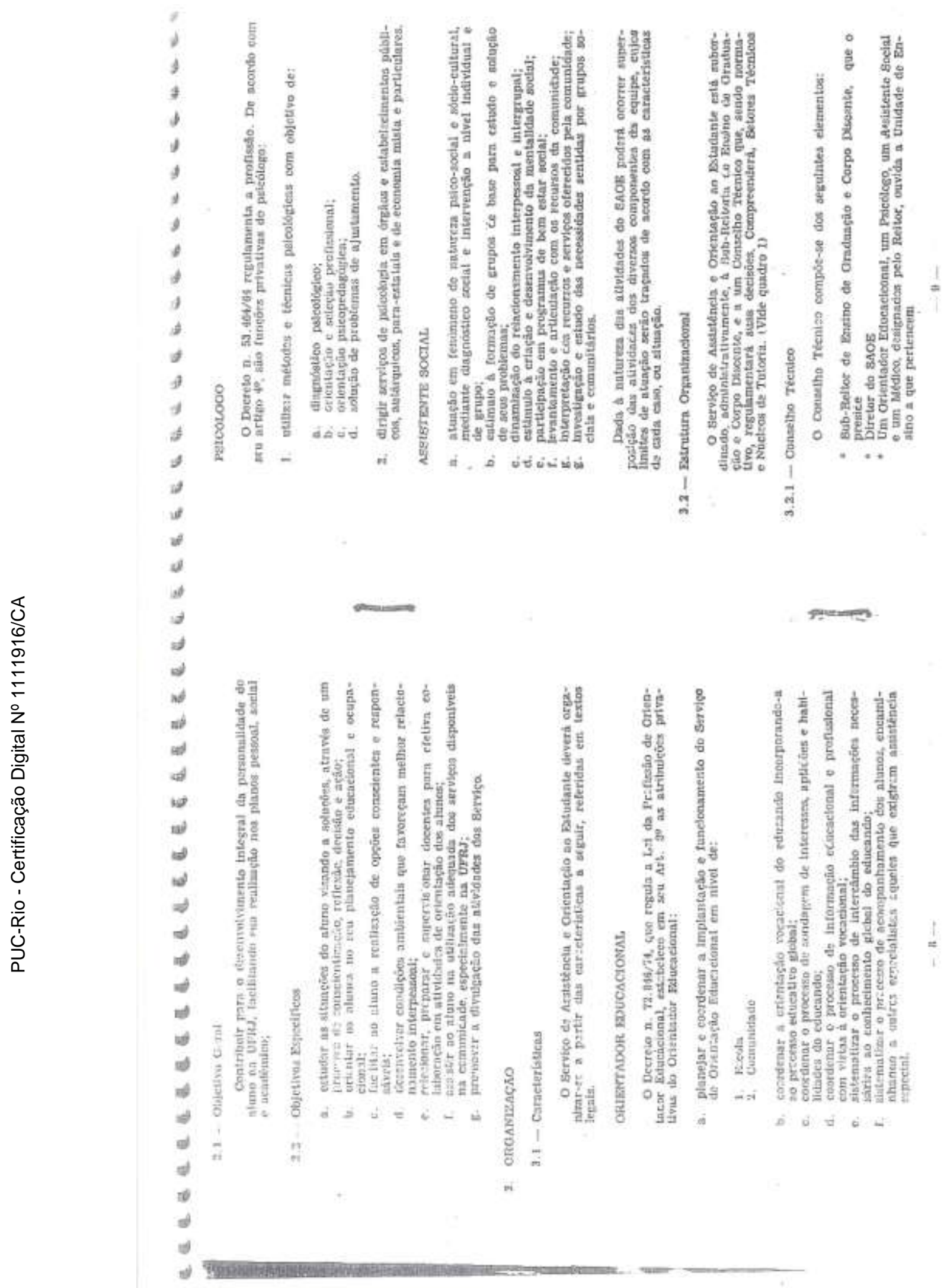




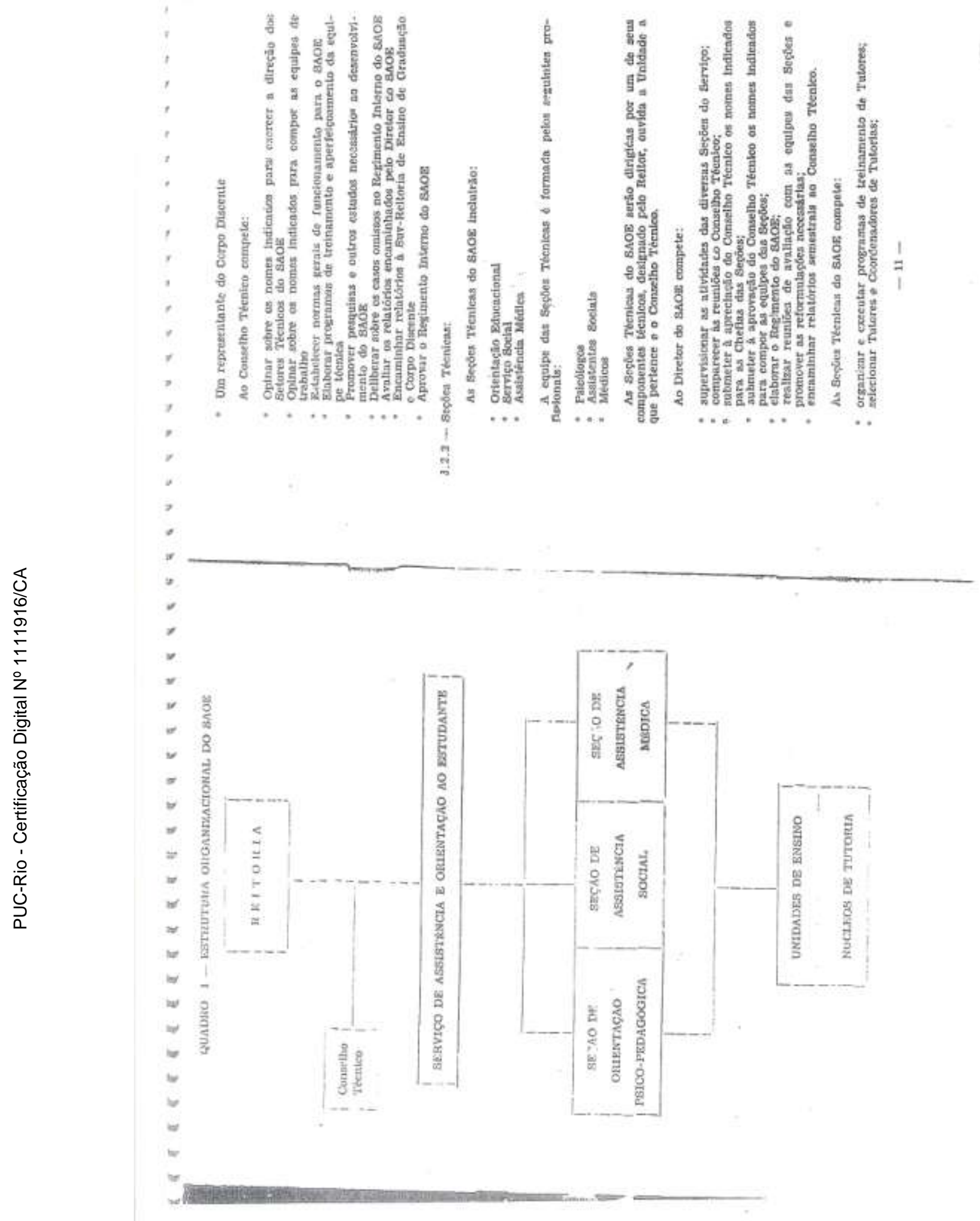



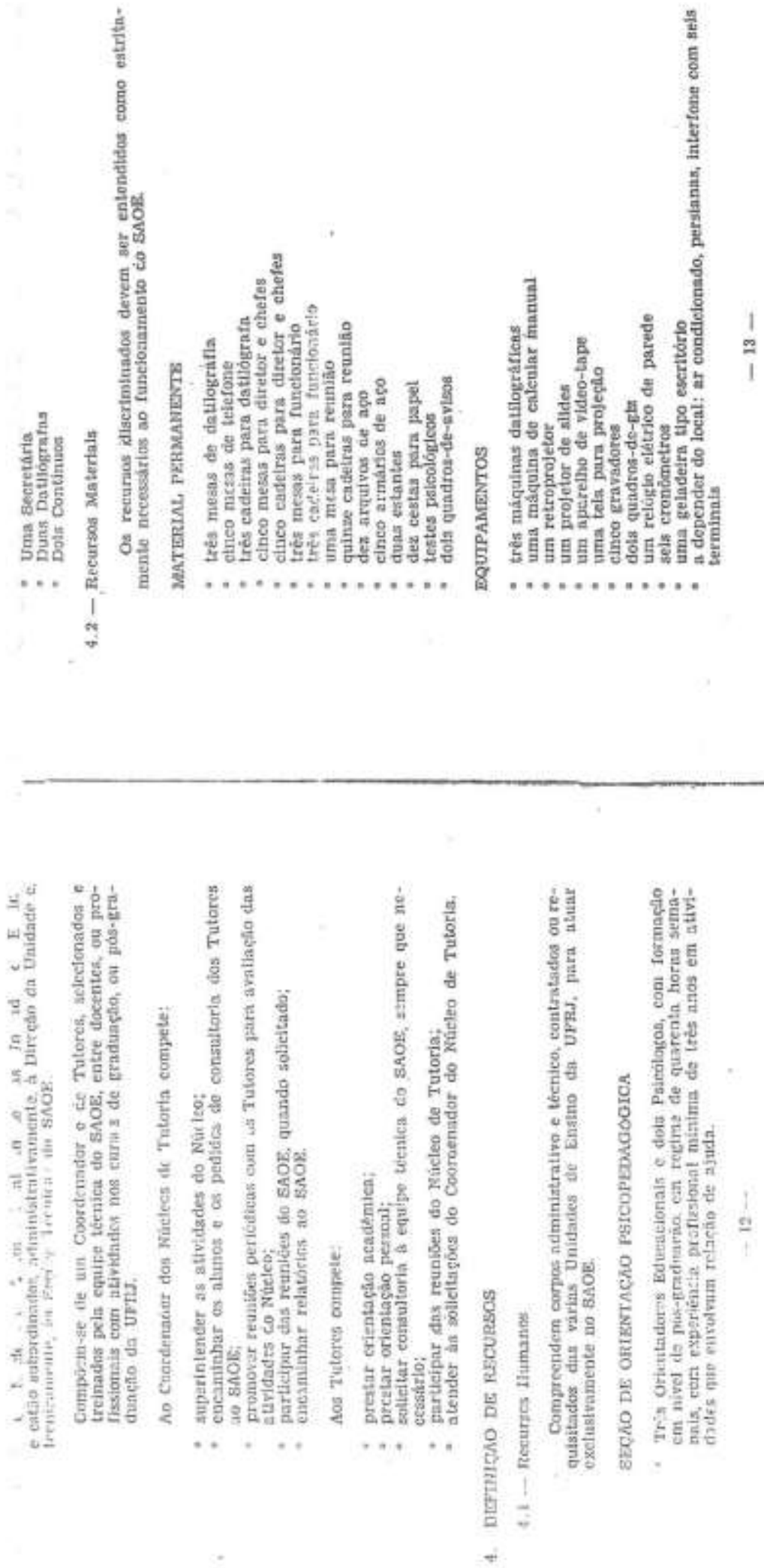


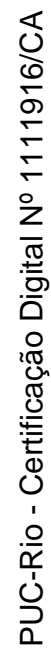
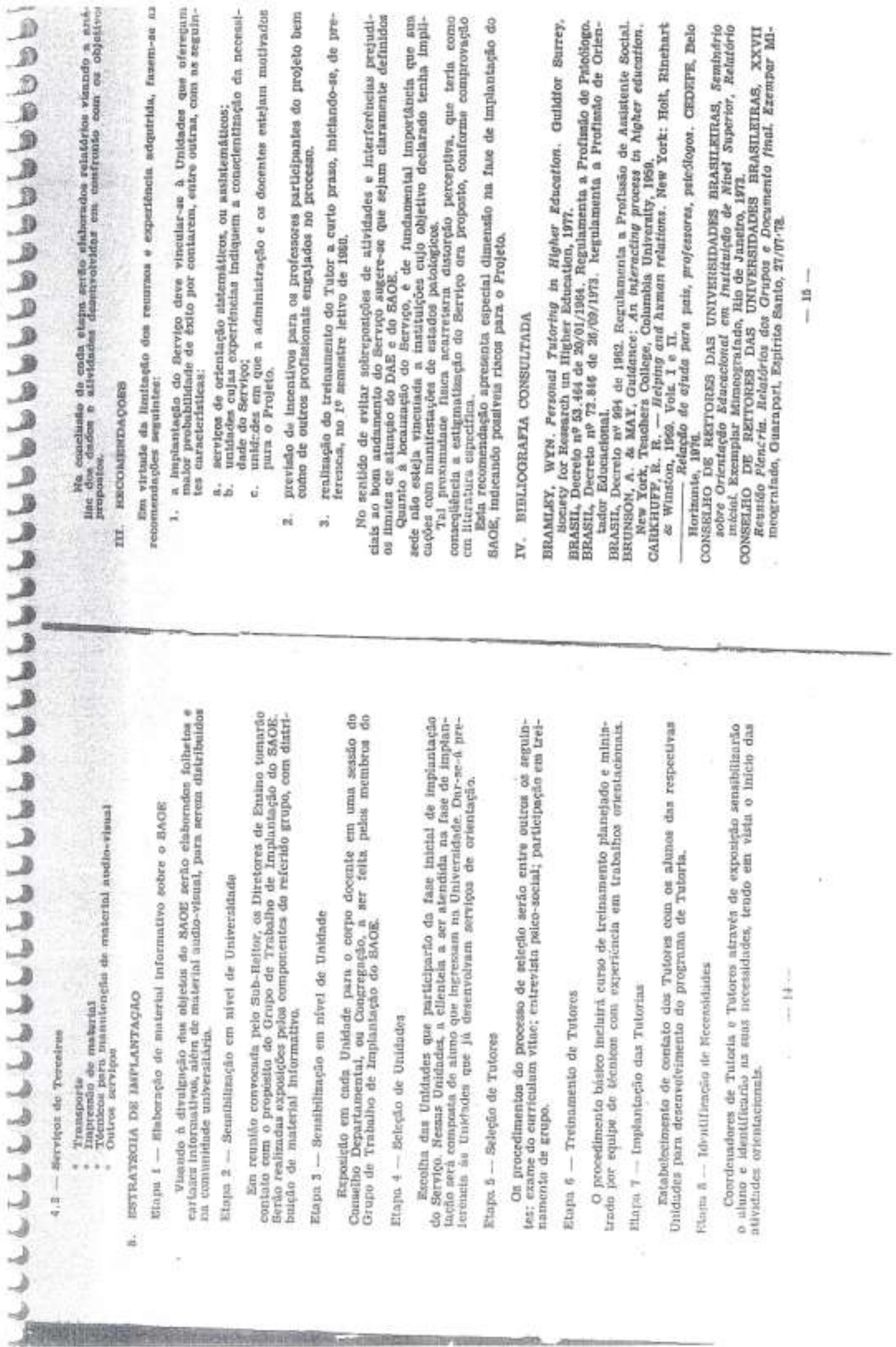
7.3.

Anexo 3 - Projeto da Divisão de Assistência ao Estudante - DAE

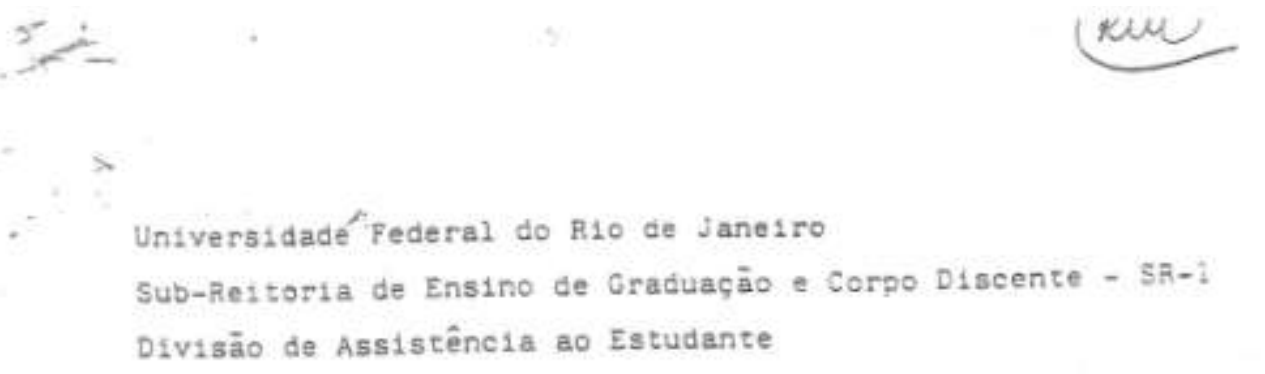

PROJETO DA DIVISÃO DE ASSISTÊNCIA AO ESTUDANYE - DAE

Prort Maria Durvalina Fernances Bastos

da Escola de Serviço Soziai

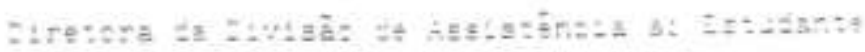


UNIVERSTDADE FEDERAL DO RIO DE JANEIRO

Sub-Reitoria de Ensino de Graduação e Corpo Discente - SN-1

PROJETO DA DIVISÃO DE ASSISTENCIA hO ESTUDANTE

o projeto da Divisäo de Assistencia ao Estudante ter co mo concepçāo central a articulação essencial entre o ensino e pesquisa no processo de formaçāo do sujeito discente.

Esta concepçäo decorre de una análise da realidade onde se constata que o avanço cientif1co e tecnologico, deste final de século, aponta para a necegsidade de uma mudança radical nos métodcs de formaçäc te recursos tumanos. Andependente sa aisca-

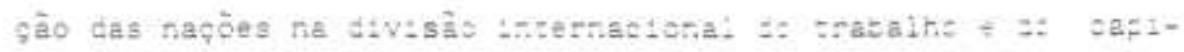
tal. A rapidez com que o connectmentz. recnizas a materiats se atualizam e se modiftoam, nảo resistindo mesmo ao periodo er que o estudante passa na Universidade etr processo de formação profissiona:, especialmente nas áreas de ponta, exige uta recomada da discussão sobre a formação deste sujelto que estanos diplonando a cada semestre. Se nào podemos asigegurat as estutar, te que, uma vez treinaco, en seu sentido restrito de acesso às céchicas e destreza en sua execucāo, será un profisajona: er:z ente e competente, capaz de competir no mercado de trabalno pe10 resto de sua vida ativa. zorna-se necessario mudar drastica- 
mente = conteudo e s estrategia, na cusca se formaclic te if sujeito capaz de pensar o seu tempo, de se imbuir de uma plasti cidade indispensavel a fazer face a rapldez das mudanças e alem disso, ser capaz de criar novas formas, métodos e processos de conhecimento. Como disse José Paulo Neto, na I Semana de Graduação da Escola de Serviço Social "nosso projeto de formaçăo pró fissional deve contemplar un profissional que atenda as demandas dadas, mas que seja capaz de prospectivar, de antecipar de mandas emergentes".

Mas nāo é só a Universicade que precisa mudar seus métọ dos. Alıás a reforma e a mudança de concepçäo da estratégia de formação de recursos humanos está relacionada ao projeto que a sociedade brasileira gesta para si própria. Especificamente com relaçäo ao aluno, e isto temos clareza que só pode ser gerado no tecido social, ou seja, que acompanhe o processo de formaça do estudante desde o pré-escolar, se faz necessária a problematizaçäo de seu projeto de vida expresso no acadêmico e que se procure uma formação plena que supere a ideologia da aquisição de diploma de nivel superior, caracteristica marcante do proces so de massiftcaçäo da Uriversidade nog lilztmos 20 anos.

A Política de Valorização da Graduaçào e a Assistêneia ao Estu dante

A Universidade Federal co Rio de janeiro tooje se c::Lca cono careía imprescindivei tecuperar a discussêo sooth a formałâo de seus alunos, tieconnece a necessidade da zeronads 
dos rumos da Universidade zan base em artierios marcacanerse I cadémicos e nesse sentido opta por uma polítlca clara de valor: zação da Graduaçâo, tentanco resgatá-la no seu papel essencia: e re-estabelecer o seu vinculo natural com a pesquisa e a pósgraduaçāo. A própria articulaçāo da UFRJ contra o desvio de suas funçōes acadêmicas gerou uma coesão da grande maloria da comunidade em torno da proposta de sua reorientaçāo, que pode ser o elemento-chave das mudanças. No entanto, é prectso que c grupo hegemônjco que conquistou, através do debate e do convencimento pela justeza e pertinéncla de sua proposta, o poder de dar direção à UFRJ, não perca o momento privilegiado de esmiuçar e explicitar as estrategias de seu projeto e implementar as mudanças necessárias e urgentes. A Divisäe de Assistência ac Estudante estreltamente articulada à proposta de valorizaçäo da Graduaçáo questiona as práticas anteriores encaminhadas por outras gestōes e problematiza as suas funçōes em novos parânetros.

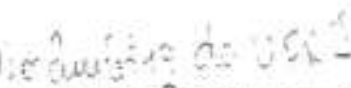

Em primeiro lugar, a assistência ao estudante é entendi da como uma proposta articulada a principios e questōes gerais pertinentes ao conjunto dos alunos da Universidade. Ora, os ale nos de UFFi. qome os de qualquer unfversidade traskietse. \#especial das pit:Las, apresentar cono zaracteristica -arsartâ a diversidadé. $\hbar$ primetra tifererça, de earáter geral. A fuar: a origem de classe social, processo intensiffcado nos iltimes 20 anos $n$ e universidade brasileira. Na UFRJ, nos últimos 4 anos por mudança no vestibular, pode ser verıficado un processo de fiitragem sócio-economico mais acentuado. No entanto, ocorre uma variaçäo por curso. For exemplo, enquanco que dos candicascs classificados para a UF̄j os de Medicina apresentan um ind:es

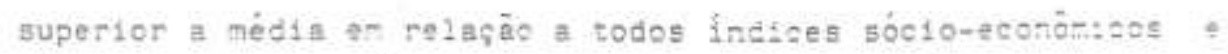
socio-culturals, aiè de registrarer a maior média na classté caçäo geral, os eluncs de Ceografia, Letras e Artes apreserta- 
todos Indices infertores a zedia, trelusive coupar os distice lugares na média global nas provas. Outro dado é que $70,95 \%$ doa pais e 44,23\% das mäes dos allunos classificados para Hedicina nesse mesmo ano, possuem grau universitário e apenas $31.03 \%$ dos pais e $17,24 \%$ das mäes dos alunos de Letras possuem curso supe rior,

A vinculaça de classe leva consequentemente, mas não inearmente, a ldentificaçào de diferenças quanto a acesso a bens culturats e simbólicos e na forma pela qual se dá o proces so de soclalizaçāo destes individuos.

No entanto a diversidade não se restringe a questāo de origem de classe, uma vez que verdadeiros talentos podem ser dentificados no grupo de estudantes oriundos das classes trabainadoras. 0 elemento biológico, a inteligência, a aptidão, a escolha da carreira adequada face as especificidades e necessidades de cada um, podem se tornar aspectos decisivos na performance do aluno. Por outro lado, dado que a trajetória de vida do homem nāo depende exclusivamente de sua vontade, acontecimen tos que caracterizam uma conjuntura e aqueles peculiares a cada um poder tocer as pessoas sob eiversos aspectos a deternina: $\because$ a

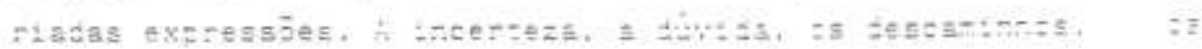

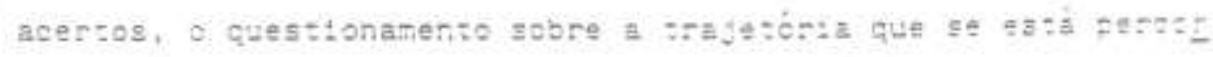
renco sâo elenentos corstrutuvos da condį̣àc humark.

Todas estas questōes, passiveis de se expresser no est: dante, independente de sua orlgem, e outras peio seu carater histórico, levan a configuração de um quadro com inumeras vaHavets que expressa $\sigma$ encrme arco de situagōes-problera e dif: cuidades generalizadas com as quais se defronta, sob as meis t: ferentes facetas, O corpo discente. Aqu: reside o grande desaflo à Divisão de Assistência ao Estudante, ou seja lnclut: esta diversidade do alunado no seu projeto de trabalho com vistas a 


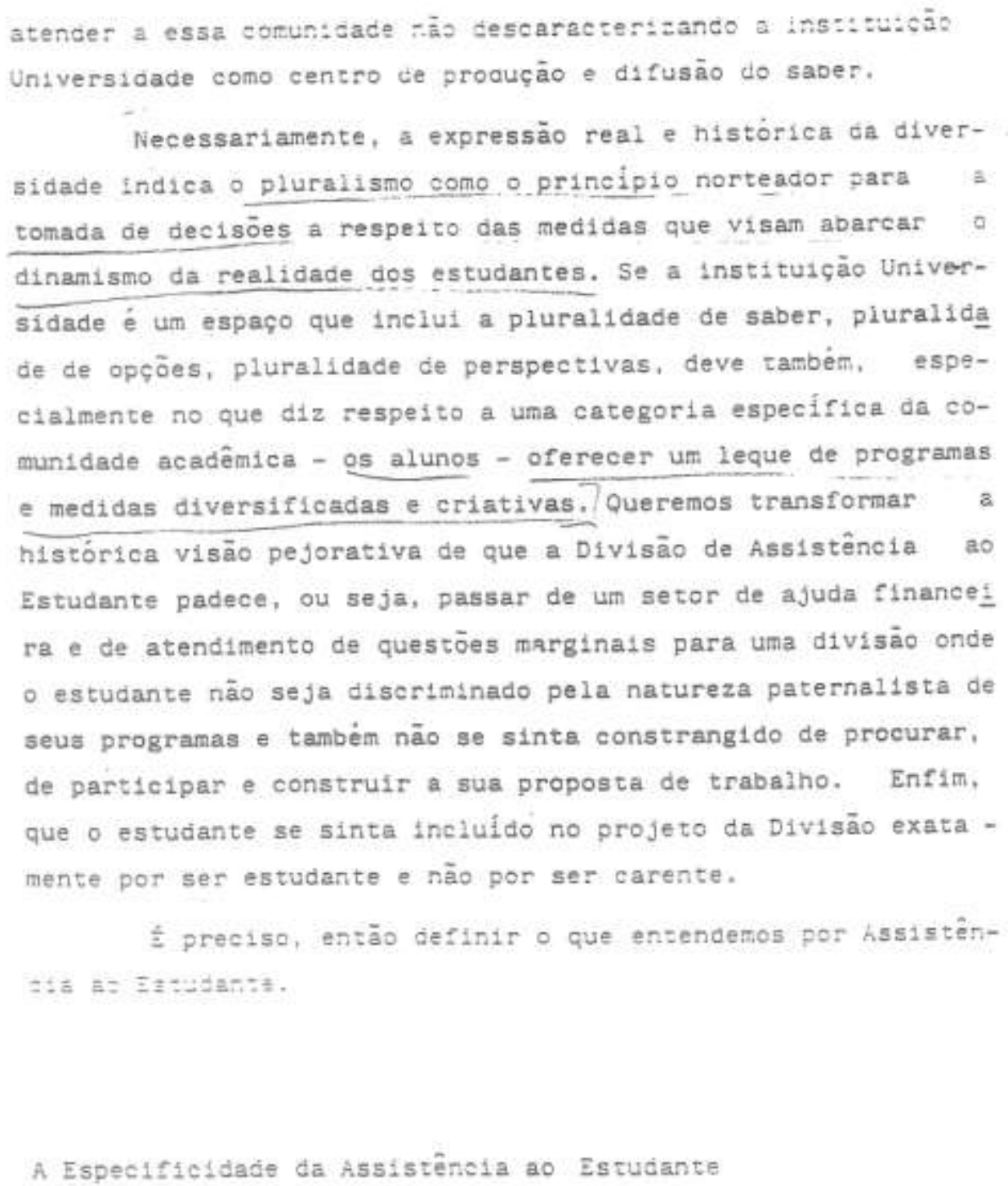


ausência de recursos Stnanceiros deven zer encaminnadcs a iuz de uma análise do projeto acadêmico do estudante e o da Universidade.

A. carência, situaçäo econômico-social que atinge considerável contingente da populaçāo brasileira e parte de nossos estudantes, é equacionada como um conjunto de problemas que dificultam ou impedem a consecução do projeto de vida a que se propōe o estudante ao entrar na Universidade. Neste sentido. procuramos, nesta estrutura de dominaçāo e nesta conjuntura de crise econômico-social, delinear um perfil acadêmico pertinente a assistência ao estudante e ao confunto de medidas, que visam proporcionar um encaminhamento norteado para o cumprimento do projeto a que se propôs o estudante, que a comunidade acadêmica acatou e espera ver realizado, sob pena de fracassar.

Esta concepção revela a especificidade da assistencia ao estudante. A noçäo de assistência deve estar vinculada a um projeto acadêmico porque do contrário, adquire uma fisionomia e descaracteriza a Universidade como uma institulção de producão e dffusão do saber. Ma:s alnda, desvinculada da proposta cadêmica a assistência discrimina e segrega o estudante con ti-

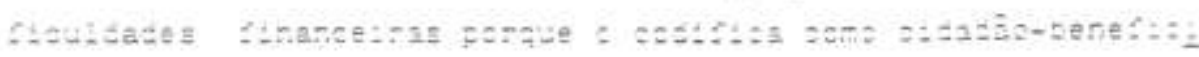
ario de un programa assiszencial blobal a máo cone un biunc jue apesar de snumeras adverstdades ingressou na tniversidade :cinteresses e necessidades próprios, caracteristicos de un portador de um projeto de aspiraçäo soctal que passa pela especia11 zação do saber.

A proposia $\dot{a}$ que a assistência näo seja un fin em I: mesma, mas que faça a mediação entre o interesse e a demanca sz cial por um prosissionai competente. a proposta de una univers dade que viabilize um processo de ensino-aprendizagem crisico capaz de fornecer respostas numa sociedade em rapida mudarfä 
e uit genuino projecs de ermaçã profusstonal do aiuno.

No entanto, o processo de formaçāo profissional do ailuno pode muitas vezes ser uma resposta a uma pressāo social de adquirir um diploma universitario ou mesmo a pressōes camillares configurando una outra ordem de dificuldades para o estudante. Alnda adolescente no momento em que entra para a Universidade e vendo surgir necessidades e interesses que não pode su prir com os recursos da familia, inexperiente e com difieulda des para definir prioridades o aluno tende a desviar o curso de graduação, näo avalíando em profundfdade as consequênctas de um retorno posterior ou mesmo do abandono do curso para 0 seu projeto de vida.

Está claro que a evasăo do aluno da Universidade ou mesmo o prolongamento exacerbado do curso näo é prerrogativa E penas daqueles oriundos das classes populares. Podemos verificar verdadelros talentos, nas mais diferentes áreas de conhecimento, que entram numa cadeia de reprovaçöes, ccm a consequente queda de rendimento acadêmico, numa flagrante desadaptação à ca misa de força que, en muttos casos, se constitul a grade currioular e a impessoalidade caracteristica de determinados cursoz

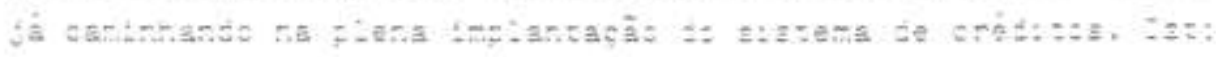

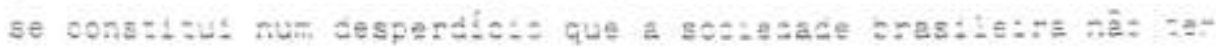
cactfe para suportar diarte do quadro de tisparidadea a tiafuI çōes, que caracterizam este país etr rápito processo de modernizạ̄on, ao mesmo tempo convivendo com estruturas e práticas atra sadas tipicas de una oligarquia decadente. \$ preciso investir no direcionamento do corpo discente desta Universidade de mane: ra a acelerar a formação de seus recursos humanos, tdeñtfisa dos os problemas que a impede dentro do ittmo previsto. fier disto é preciso definir uma politica clara com relaça aos seus zalentes, tendo en perspeotiva que a iscronita trtelectual se constitut. numa ltopia. 
Este trvestimento deve estar fundamentado numa poli:iza clara de valorizaçāo da graduaçāo entendida como atividace f:r da Universidade con medidas especificas e articuladas que a cPe ractonalize, tals como un programa de bolsas de monitoria, Iniciaçäo cientifica e artistica, um programa de estágio profissionalizante remunerado, un proğrama de orientaçäo pedagógica e psicomsocial, todas estas calcadas numa prática efetiva de orientação e acompanhamento acadêm1cos por parte dos professores. A Divisão de Assistência ao Estudante tem clareza que a valorizaçäo do aluno e de seu projeto encontra sua base na e cademia. Neste sentido o ponto de partida para qualquer ato de assistência ao estudante passa pela situação e avaliaçäo de seu desempenho acadêmico entendido en termos elásticos de maneira a abarcar suas diversas expreszōes na sua Ünidade de énsino. Interessa, portanto, à Divisão, dados abrangentes que venham a de linear a situaçāo acadêmica do aluno, suas dificuldades e suas potenclalldades.

O Eixo Censrai da Proposta de Divisäo de Assistêncià a: Es:ute: te

A operacionalızaçào desta proposta depende do funcionamento das comissōes de orientaçāo e acompanhamento acadêmico das unidades de ensino, cuja criação fol prevista na Resctuçäo $n$ $5 / 89$ do Consetho de Ensino de Graduaçäo, que dispōe sobre cance lamento de natricula por insuflelência de rendimento acadêmis:. 
Heste sentido, proponos uma art:culaçäo smediata entre estas comissōes, com a mediaçào das unidades e dos centros $e$ a Divisāo de Assistência ao Estudante, entendendo a orientaçāo e acompanhamento acadêmico, como um processo de orientação com direçāo intelectual necessariamente pluralista, por parte de um grupo de proressores experientes, com imprescindivel conhecimen to da rilosofla e da grade curricular e cuja liderança resulta de sua produçāo académica e profissional. A perspectiva é de um trabalho preventivo, na 1 dentificaçäo de diflculdades do corpo discente, ultrapassando o eritérto estritamente curricular, pin çando problemas que a própria universidade tem o dever de encaminhar e propor soluçōes. O trabalho da Divisäo de Assistência ao Estudante articulado às comissões de orientaçāo acadēmica se constituiria na via institucional ou formal de encaminhamento dos alunos. Dada a situaçäo em que se encontram as práticas de orientaçāo acadêmica nesta universidade a Divisāo vê com preocu pação a vinculação de sua proposta ao trabalho destas coaissōes. Por outro lado, entende que $\dot{e}$ urgente uma participação ativa do corpo docente neste trabalho e aposta que a viabilidade desta proposta é também de responsabilidade de toda a comuntdade acacềnica.

Os Canais Alternetivos de viabilizaçăo da proposta

Avallamos tambén, como produtiva a abertura de cana:s de comunicaçäo alternativo com 2 corpo discente sendo un azravés de um fórun de discussão com as entidades estudartis, e é imprescindivel dize:, resguardando sus autonomia, cono fater 
de abertura para o debate. contestaçào e espaço de critica $\because$ tais para o crescimento de qualquer institulção, em especial a Universidade.

Outro canal seria a oriaçāo de fóruns de discussão Informais, setorizados por centro ou unidades, onde os alunos pudessem colocar suas diffculdades $e$, através da troca de experiência com seus pares e de una participaçāo ativa dos docentes, oferecendo uma orientaçäo profissional e intelectual seguras, pudessem conjuntamente encontrar pistas, propostas concre tas e instrumentos para o encaminhamento e redfrecionamento, der tro e fora do espaço da Universidade para os projetos acadêm1 cos dos alunos. Este grupo de discussāo de caráter filosófico social, embora com a possibilidade de encaminhamentos concretos teria em primeiro lugar $e$, necesaariamente, um carater de infor malidade de maneira a preservar a critica, o debate intelectual, a provocaçāo construtiva, problematizando ao mesmo tempo o projeto acadêmico individual do aluno e o sujeito concreto que a Universidade almeja formar. Por outro lado, para dar direção a inquietaçäo característica do estudante que procura ajuda, a proposta deveria trazer a marca da eflolêncla nas alternativas oferectibs acs estudentes atraves de medidas concreas :ais asmo bolsas, estágios, projecos de pesquisa. protessores zrtenzadores, convêntos de 1ntercâmbio cientiffoo-culturats nastorais ou Internacionais, prestação de serviços, atividades extra-cus rfculares e culturals etc. O módulo minimo da equipe responsá vel pelas discussöes incluiria a assessonta de um professor ou professores pesquisadores experientes, com perfil intelectual e fllosófico elevado. um professor-educador de manelra garan:1: na discussäo, as possibilidades de avaliaçäo, a partír do amplo espectro que se constitui o conjunto de oporzunidades curricules res da UFFJ, e finalmente um professor, pesquisador ou profiss! onal que por temperamento seja um animador de discussăo de -aneira a assegurar a vitalidade do debate e o interesse do eszudante em busca de aiternativas. 
A probiematizaçāo ds projeto acadêmico e de :1da as sujeito discente passa, necessariamente, pela questāo de sua formaçāo como homem püblico, cidadāo pertencente a uma comunida de. Isto inplicaria na refiexão interna do projeto académico de estudante, de que forma vê seu papel na construçäo da sociedade. como efetıvamente vê sua ação imediata e futura, de que forma inclus a comunidade naquele seu projeto de maneira a superar 0 seu carater individual e, ultrapassando os muros da universidade se perceber como un cidadão de uma comunidade que já deline1a uma conf1guraçào cosmopol1ta e internacionalizante, transformando-se num cldadäo do mundo. O que, alén do estritamente acadêmico, o aluno já visualiza para seu futuro como homem público, ultrapassando a restrita habil1taçäo profissional, as possibilidades de realização de outras alternativas, ocupando outras posiçōes na comunidade, na área política, da gestāo pública, de performance cultural. Esta reflexäo seria mais efetiva se superasse o lado idealista da discussão, encaminhando o debate da realidade sóc10-cultural e indicasse caminhos concretos a percorrer, ainda na universidade através de atividades de carater social, de maneira a se familiarizer con o amplo espectro econôtico-social e as desigualdades na sociedade trasileira.

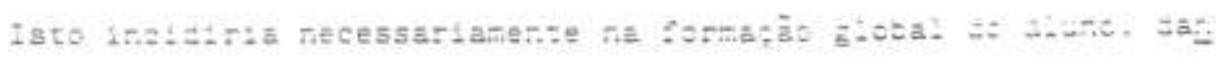
do-1he, através da civersidade de sua experiência. cuatificạàc para desempenher sua profissão de forma alnda mals competente.

A concepçāo deste projeto com esta perspectiva f1losót ca, aponta ainda para uma das articulaçōes internas possiveis na Sub-Rettoria de Graduaçāo, Junto à Divisăo de Atividades ExtraCurrieulares. A inserça co fovem na sociedade brasileira de hoje sugere un temário, em relaçāo ao qual a Universıdade dispöe de resursos humanos a técriccs para colocar en discussä. cotro por exemplo a questīo da droga, da sexualidade e da hIDS. da gravidez ne adolescêncla e durante o curso de graduaçäc, co- 
locando em risco nảo só a eriança, nas a mäe e pa: mukic invens, a deficiência do primeiro e segundo graus provocando un despreparo para o curso universitário. É orgânico a este projeto o propósito de encaminhar as questöes de deficiênoias na fon mação cultural do estudante. Por exemplo, problemas de ortografia e de redação, seriam tratados através de disciplinas de 11vre escolha ou cursos especla1s de instrumentallzação da lingua portuguesa, as bibllotecas teriam um horário elástico, compativel não só com un amblente intelectual dinâmico mas também com - aluno que reserva as suas noltes para o estudo, um programa de lingua estrangeira de caráter extra-curricular driblaria a ineficiência e 0 alto custo dos cursos particulares. Nesta 11nha ainda serıa interessante buscar uma articulação com $\odot$ circuito cultural do Rlo de Janeiro de maneira a garantir, por mérlto acadêmico, a audiênela por parte de alunos da UFRJ aos principals eventos culturals da cldade.

A. D1v1säo de Assistência ao Estudante se propōe a ser un canal articulador, agregador, vinculador, ao lado das unidades e centros, das temáticas levantadas e preocupaçōes apresentadas pelos estudantes, oferecendo informaçōes, apontando as alternativas disponiveis, Frocurando manter a discussào as $\ldots$ vel tnter a transdiscipilnar, encontranto elemertcs corturs te questöes que dizem respelto a varias discipitnas a frctiasōes. A Divisão tambem entende ser importante a assessoria individua: do aluno, prestando orjentaçäo e apoio, Indicando fontes e formas de acesso a informaçōes, viabilizando propostas e a busca de recursos, interpretando jargōes e macanismos institucionais de maneira a ampliar as alternativas de formaça Elobal do esti. dante. 
Algumas medidas urgentes sāo necessárias para demonstras uma efetiva operacionalizaçäo da política de valorizaçāo da graduaçāo da atual administraçāo da universidade. Ainda ho je, nesta universidade não está garantida a atençāo individualizada ao estudante na área médica, odontológica e psico-so c1al, o que revela un descaso da instituição com a sua maté ris-prina, que vivencia situaçöes que por vezes podem acarretar sérios prejuizos à sua formação. Atendemos a populaçäo vi cinal, no entanto, näo priorizamos os atores que alimentam a atividade $11 m$ desta universidade. Neste sentido propomos a oriaçāo de uma comissão, composta de representantes dessas di ferentes unldades que prestam serviços, para propor a estrutu ra e rede de atendimento médico-odontológico e psico-social dos alunos desta Universidade. Esta comissäo teria como objetivo empreender a montagem da estrutura minima do servigo, in dicando as unidades, setores e pessoas envolvidas, e também

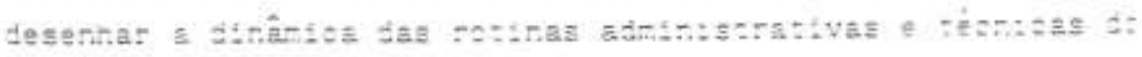
atendimento. Quanto a atendimento medtco-odontolóstez se estabelecerta u. protocolo de intençöes con as unidaaes responsáveis que garantisse um tratamento especial aos alunos com vagas e horário pré-definidos de atendimento. O papel da Div1 säo de Assistência ao Estudante neste caso seria de divulga ção đas condlçōes, local e horário de acendimento e sanaria diriculdades de articulação interna da rede de servipo visando o interesse dos alunos. Quanto ao atendimento psico-social. aqui incluido o psico-pedagógico. se faz necessária a monta gem de uma rotina de atendimento e acompanhamento dos zasos. 0 aluno interessado ou encaminhado pelas unidades sorretia :- 
cialmente um processo de triagem por uma equipe de assistentes sociais, pedagogo, psicólogo e psiquiatra treinados, visando uma avaliação de cada caso de maneira a respaldar un encaminha mento preciso aos setores hab111tados tals como o Instituto de Psiquiatria, O Setor de Saude Mental do H.U. e outros da área de Pedagogia. A depender da necessidade, seräo contatadas outras 1nstituiçōes fora do campus da UFRJ sempre no sentido de atender prontamente o estudante. Pretendemos orlar um setor da Divisāo - um posto đe atendimento da DAE - com uma equipe de profissionais na Praia Vermelha, para facilitar o acesso dos estudantes daquele campus e aqueles vinculados a unidades instaladas no centro da cidade. Na área do atendimento psico social e pedagógico, alèn de triar, a Divisāo de Assistência ao Estudante teria como papela estimulaçäo para o tratamento. quando for o caso e o acompanhamento da situaçäo do aluno arti culada a seu desempenho acadêmico.

Uma outra questão de interesse fundamental para o estụ dante é o estagio profissional. Isto decorre de uma analise que ele proprio faz do mercado de trabalho que pretende se inserif. Em geral, as empresas e instituiçōes empregadoras exiger do

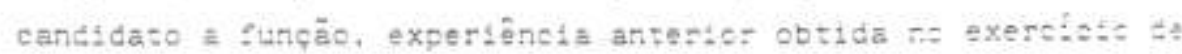
atividades ne area. For outro tado, poucos eursos protissionais exigea eatáglos como parte da atividads curricular a a urivers: dade nāo tomou de frente esta questão essenclal para o aluno. Esta s1tuaçäo configura un quadro caótfco. Podem ser veriffca das algumas experiências positivas, mas pontuals, de estágio $\underline{\varrho}$ ferecidas por algumas empresss e mesmo por unidades da univers: dade. Mas na maloria dos casos se traca de exploraçâo dos recu sos humanos que a UFR. tem formado. Na ansia de receber una remuneraçäo nem sempre garantida, quando nâo abdicar destâ, * ucertificado de estigio, os alunos se sujeitan a uma carga norí ria excesstva, que impece a conclusāo de seu aurso em sempo nog mal, se submetem a funçōes e atividades que descaractertzar. ou 
mesmo näo tem qualquer relaçäo com o seu curso. Firalmente. som - comprovante de estág10 na mäo e nem sempre com a experiência pretendida, podem sequer competis posteriormente no mercado de empregos. O estágio, desta maneira. se constitui num problema a mals pars o estudante, perde o seu caráter educativo e de for maçäo profissional. A UFAJ precisa reconhecer o estado de abandono en que se encontra o estágio curricular e extra-curricular e definir uma política de enrrentamento da questāo. A primeira delas seria a institucionalizaçāo de coordenaçōes de estágio em todas as unidades, criando um sistema de acompanhamento e super visão dos estudantes por parte dos professores em articulaçāo com os profissionais das entidades que oferecem estágio. Defi nir os critérios minimos de acordo com a lei de estágio e ou tros critérios de elegibilidade considerados essenciais para a UFRJ, para encaminhar seus alunos para empresas e instituiçōes públicas. É imprescindivel, no entanto, que a UFRJ articule re cursos financeiros o humanos para implementar esta politica, jả que a atual estrutura não tem sequer condições minimas de encaminhar o volume de trabalho nesta perspectiva. Ainda no que tan ge a estág10, pretendemos empreender uma experiência plioto,vin cuiandoro a projetos de pesquisa. de maneira a ultrapassar as

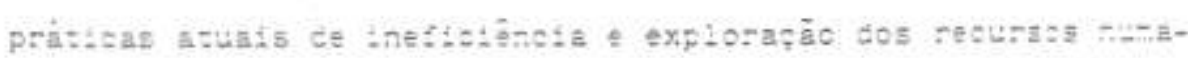
nos da universidade, através de convênios de cooperaçäo técriç cientifica por parte de UEal em contrapartida a oferta ce estág10 remunerado aos estudantes, pelas empresas e instituiçōes p. blicas envolvidas. Este programa implicarıa na partııpaçăc aț va dos docentes näo só viabılizando os projetos de cooperaçàc cono iambér garantindo uma supervisão pedagóglca aos aiuros.

A Divisäo de Assistência ao Estudante entende coro fundamental a defintçāo de uma politica unificada de bolsas, E partî de oritérios acadêmicos, de maneira a dar suporte a froposta de valorização da Graduação e de una formaçäo interral de 
aluno. A experiêncta dita que a simples obtenção de ura bolsa não garante o sucesso nem a formação do estudante em tempo hábil. No entanto, quando a questăo que impede a assiduidade de atividades acadêmicas previstas é a financeira, a bolsa de estu dos desempenha um papel decisivo senão condição sine qua non. Do contrario, o estudante tentará compatibilizar o seu estudo com ums atividade remunerada entrando, com grande probabilida de, num processo gradatıvo de desaceleração, trancamento e aban dono do curso. E preciso, no entanto, que a Universidade, já que vem ao longo destes anos, proplciando bolsas de caráter as sistencial, Saca uma autocrifica sobre os seus critérios e valor. Quanto aos critérlos de elegibil1dade, soliclta-se atual mente ao aluno candidato as 500 bolsas de estudos disponiveis da $5 R-1$, inúmeros comprovantes de renda, seus e os de sua fami11a, criando prontuários e arquivos tảo volumosos quanto ineficazes. Em contrapartida, agracia-se o estudante com uma bolsa com un valor apenas simbólico e que nunca sofre atualizaçāo. 0 resultado é que o estudante näo pode contar com aquele rendimen to para encaminhar seus estudos. É certo que os estudantes que realmente sāo carentes retiram o cheque nos primeiros dias de pagamento e consideram a bolsa indispensável. Queremos discutir a respetio de uma solsa te estudos ditistda a essuzaries da UFF, que soram no Rlo de ianeiro.

Os dados da Comissāo de Vestibular de 1989 mostram que a grande maloriá dos alunos classificados para a UFRJ é de solteiros $(98,01 \%)$ e $96,32 \%$ mora com a familla. Este é um dado caracteristico da realidade brasileira, em primeiro lugar, com re lação ao fato de que o jovem tende a se desligar da lamilia na rase adulta, na oportunidade do casamento. Mencionamos anteriog mente, que em muitos casos - não podemos definir o quantitarivo no momento - o estudante tende a procurar a independênola econố mica da familia logo após o Ingresso na Universidade e começa. 
muitas vezes, ao mesmo tempo, o desligamento do domicilio familiar. No entanto, quando entra na Universidade, a grande maior1a, $82,65 \%$ (dados da Comissäo de Vestibular - 1989), nāo exer ce qualquer tipo de atividade remunerada. Em conclusāo, é no decurso de sua formação que o estudante se coloca a questão da Independência econômica, ou antes disso, o compromisso de retor nar a ramilia o Investimento recebido até essa fase de sua vida. Se a Universidade estiver disposta, através de uma politica de bolsas consequente, enfrentar esta questäo que tambén é de geu interesse, deve definir um quantitativo que seja compativel com a realidade do estudante, ou seja partindo do principio que tenha garant1da a sua moradia. Nesse sentido o cáloulo deveria incidir sobre os gastos com transporte, alimentaçäo e material escolar. 0 segundo ponto $\dot{e}$ que estas bolsas deveriam ser atual 1 zadas de acordo com a inflaçäo.

Ao lado disto a Sub-Reitoria de Graduaçäo deve Iniciar uma discussäo sobre uma politica de fixação do aluno no campus da Universidade, partindo de vários principios. Se a proposta é de aumentar o calendário de 180 para 220 ou 240 dias 15 to $51 \mathrm{gnt}$ fica que o aluno terá mals tempo de perticipar en atividades de

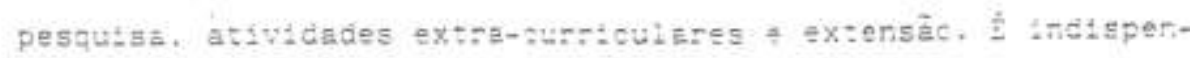
sável que a unfversidade crie un sistema de iransportes de raneira a garantis o acesso e a saida de estudantes do campus.que crie centros de vivência socials \& garanta que ambientes acadêmicos como as biblfotecas sejam dinamizados, que propicie ativi dades estimulantes ao estudante de maneira a desejar permanecer no campus, que empreenda uma correção no sistema de alitnentaça no campus Fundão, restringindo-a a estudantes e funcionárıs cor resultante melhoria de seus serviços e criar un sistema descentralizado de alimentaçäo de maneira a garantir sua qualıdade e facflitar o seu acesso. 
Outra área que exige uma definç̧a institucsonal clara è com relaçăo ao alojamento de estudantes. Verifica-se nesse setor uma ausêncla de investimento nas instalações atuals, a desarticulaçäo administrativa, a ausência de informaçōes precisas sobre o contingente atual, a falta de uma politica que regu lamente as práticas internas do alojamento e um quadro técnico irrisórto para encaminhar as tarefas minimas exigidas neste setor. Esta realıdade aponta para a necessidade de criação de uma comissāo encarregada de propor uma politica para o alojamento dos estudantes.

À DIvisão de Assistêncla ao Estudante propõe-se como at1vidades e tarefas a serem cumpridas nos próximo quatro anos:

- promover a articulação com as unidades de ensino, com os coordenadores de curso e as comissōes de crientação acadêmica para a viabil1zaçāo da proposta;

- viabilizar uma análise constante da política e práticas relativas às Bolsas;

- montar o Quadro de Estágio Curricular Obrigatório da UFRJ por curso;

- levantar dos Convênios de Estágio da UFfJ firmados pe la Reitoria e por diferentes unidades fsoladamente:

- levantar a situação dos estagiários da tris. vinculados as uridades de ensino ou estabelectdos por iniciat:va própria;

$\rightarrow$ - aglilzar o estabelecimento de uma politica de estágio da SR-1 criando mecanismos de articulação entre ensino e pesquI sa com os programas de estáglos remunerados curriculares ou nào;

- empreender o cadastramento dos alunos interessados em estágio:

- informatizar todos os procedimentos relativos a bolsas, estáglos e convêntos de estágio 
- agilizar a articulação entre os diferentes setcras de maneira a garantir um atendimento médico-odontológico aos estudantes da UI RJ;

- constitu1r uma comissão para propor uma estruturaçāo administrativa e técñca e uma regulamentaçäo sobre o funcionain mento interno do alojamento estudantil, garantindo todos Qs melos no processo de transiçäo de implantação deste setor:

- constituir uma comissão para propor,a estrutura de a tendimento psico-social individualizado e grupal dos alunos;

- articular diferentes setores de manelra a garantir a điscussäo orientada do projeto acadêmico do estudante:

*- acolher os diferentes problemas trazldos pelos estudantes, verificando sua vinculaçio acadêmica e se empeuhando pa ra dar um encaminhamento satisfatório;

- procurar identiricar, Indicar e resolver quando possí vel pontos de estrangulamento na relação dos estudantes com a instituı̣̄ào e com a comunidade acadêmica. 
7.4.

Anexo 4 - DAE: condições para a atuação emergencial e calendário de atividades

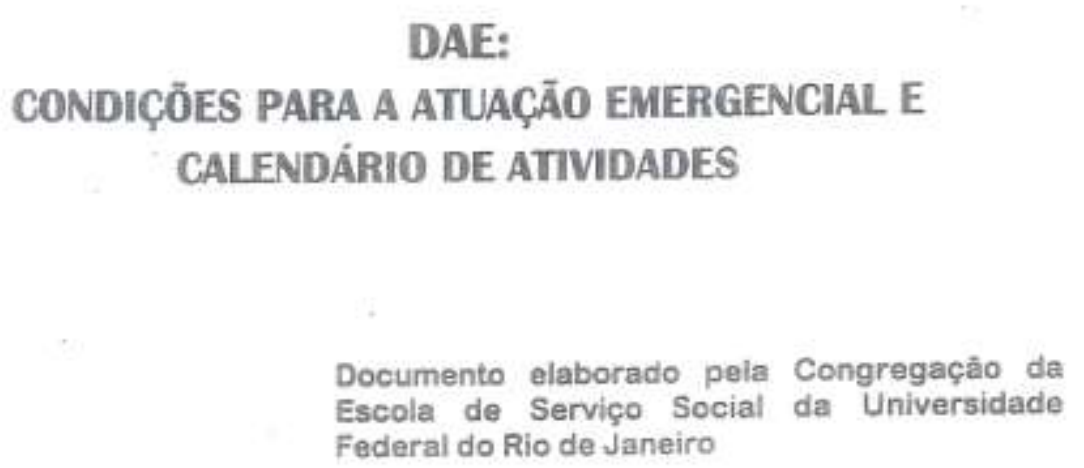

Pibo de Janeiro, 10 de novenbro de 1984 


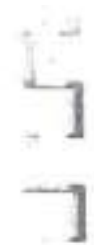

]

]

7

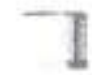

1

$$
\text { 了 }
$$

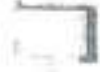

11

$6-1$

11

1
$=$

hat

$1+1$

]

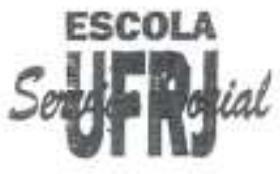

\section{SUMÁRIO}

Introdução

.03

A assistência ao estudante na UFRJ.

Uma politica para a DAE.

Anexo 1 - Projeto para a Divisẩo de Assistência ao Estudante elaborado em 1990

DAE : CONOICOES PARA A ATUACAO EMERGENCIAL - CNESDARO DE ATMCAOES

$$
10 / 1194
$$




\section{INTRODUÇÄO}

Atendendo a demanda explicitada na última reuniáo ( dia 09/11/94) do Conselho de Ensino de Graduaçăo/CEG desta Universidade, referente à apresentação do calendário de atividades da Divisăo de Assistência ao Estudante/DAE, a Congregaçåo da Escola de Serviço Social - unidade que se dispöe a assumir a responsabilidade pela ação da DAE - houve por bem subsidiar a informaçâo requerida com algumas consideraçōes sobre esse órgào vinculado à Sub-Reitoria de Ensino de Graduaçăo e Corpo Discente/SR-1.

Este brevissimo texto se propōe oferecer ao egrégio Conselho de Ensino de Graduaçâo/CEG indicaçŏes elementares para que se possa discutir com um minimo de propriedade a problemảtica da DAE.

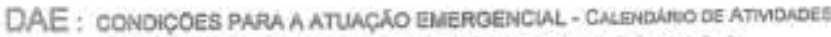

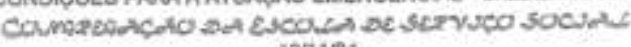
$10 / 11 / 94$ 


\section{A ASSISTENNCIA AO ESTUDANTE NA UFRJ}

A observação rigoroșa da dinámica da UFRJ permite uma dupla constataçăo que repercute em todos os segmentos que compōem a comunidade acadèmica:

$1^{2}$. - uma ponderável parcela do alunado da UFRJ depende diretamente de uma politica assistencial para inserir-se no circuito educativo da universidade:

$2^{a}$. - a UFRJ năo dispōe, atualmente, de condiçōes minimas para implementar a proposta de politica de assisténcia atribuida à DAE.

Trata-se de constataçōes que podem ser facilmente verificadas e, methor ainda, comprovadas empiricamente,

Para a primeira delas, basta recordar que, em 1994, aproximadamente 5,000 estudantes, conforme quadro abaixo, reivindicaram beneficios dos diferentes programas da DAE - ou seja, cerca de $1 / 4$, ou $25 \%$, do alunado situouse em alguma faixa de carência real. Ou ainda: o fluxo de novas demandas por benericios, em 1994, foi praticamente o dobro do registrado no ano anterior. Projeçöes fundadas, para 1995 , indicam que as novas demandas devem girar em torno de 6.000 .

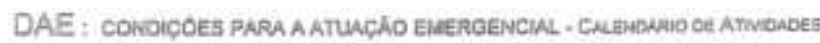

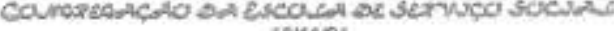

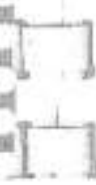
10119. 
$-1$

ESCOLA

$-1$

Serghisial

$-1$

$-1$

QUADRO DEMONSTRATIVO DA DEMANDA COLOCADA PARA A DAE/SR-1

\begin{tabular}{|c|c|c|}
\hline FRENTES & $\begin{array}{c}\text { alunos inscritos } \\
1993\end{array}$ & $\begin{array}{c}\text { alunos inscritos } \\
1994 \\
\end{array}$ \\
\hline BOLSAS OE ESTUDOS E ALMENTACKO & 1,980 & 3.500 \\
\hline ALOLAMENTO - NONOS PECISOS & 160 & 285 \\
\hline ALOLAMEMTO - RESOVMCLIO & 385 & 480 \\
\hline BOLSAS DE EITAGO (CEFET/ETFQ) & 100 & 100 \\
\hline $\begin{array}{l}\text { OUTRUS OEUWNDAS (SETOR DE ESTAGIO, ATENOMENTO } \\
\text { EUERGENCWIS, PSICO-PEDACOGICOS E SOCLUS) }\end{array}$ & 600 & 800 \\
\hline TOTAL & 3.225 & 5.165 \\
\hline
\end{tabular}

Este cenário, demonstrado no quadro acima, apenas reflete, sobre a nossa comunidade académica, as incidências da grave crise econômico-social que envolve a sociedade brasileira (agudizada pelas suas particulares expressōes na Regiảo Metropolitana do Rio de Janeiro). E, obviamente, este cenário nầo recobre, enquanto quadro de carências, somente o alunado, projetando-se também sobre o corpo técnico-administrativo. Entretanto, é 0 alunado de graduaçăo o universo sobre o qual recai a ação da DAE.

DAE : CONDICOES PARA A ATUACAO EMERGENCLL - CNLENDHTO DE ATMIDAEE

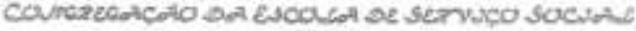
1011/9es 


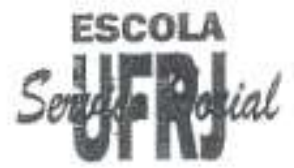

Quanto a segunda constataçåo tambèm ela nāo se restringe a meras impressôes colhidas em nossos campi, mormente na flagrante insatisfaçao das organizaçöes do corpo discente (expressas, inclusive, reiteradas vezes no âmbito do CEG). $A$ analise do funcionamento da DAE atesta a absoluta falta de condiçóes para que o órgão execute suas funçôes: o corpo técnico è escandalosamente insuficiente (dois assistentes sociais, ambos com outras tarefas administrativas, e dois psicólogos) e a infra-estrutura material é ridicula ( 0 espaço fisico e os recursos informacionais sâo precarissimos para processar a massa de dados pertinente a quase 5.000 alunos).

É evidente que nestas circunstâncias, a assistência ao estudante, na UFRJ, vern se operando da forma a mais precária. O conjunto de atividades da DAE que, desde 1992, compreende: seleçăo anual de novos candidatos ao alojamento, renovaçấo anual das vagas no alojamento; seleçâo anual para bolsas de alimentaçăo e de estudos; coordenaçâo de bolsas de estágio do CEFET e da ETFQ: articulaçấo de convênios de estágio para alunos de toda a UFRJ: atendimento individual e encaminhamento nas áreas médica, psico-pedagógica $\theta$ social - vern sendo continuamente comprometido.

Sem qualquer risco de exagero pode-se ajuizar que, no quadro atual, a assistência ao estudante, atravès da DAE, aproxima-se ao perigoso limiar da falência.

DAE: CONDIC OES PARA A ATUAC̆̈O ENERGENCIAL-CALENAAUO DE ATMONOES

a 1011124 


\section{UMA POLITICA PARA A DAE}

0 desfizamento para este perigoso limiar da faléncia nâo só deve, mas pode ser revertido.

A experiência acumulada na UFRJ e na própria DAE, bem como a potencialidade dos quadros técnicos de nossa universidade (inelusive da Escola de Serviço Social, que, com seu pós-graduaçâo è hoje reconhecida como centro de excelência) dâo suporte à projeçăo de outras alternativas. Năo se trata de um otimismo facil; antes, trata-se de uma possibilidade real : a possibilidade de, com uma definida politica de assistência e uma adequada alocaçăo de recursos (humanos e materiais), transformar a DAE pré-falimentar de hoje numa instância operativa, eficaz no conjunto de organismos da UFRJ.

E supérfluo notar que a opçấo por esta possibilidade está longe de uma simples preferência técnica - è uma opcáo oolitica. E também è supérftuo observar que existern as condiçठes para esta opçâo: os atuais dirigentes da UFRJ democraticamente eleitos há menos de 6 meses assumiram compromissos públicos que contemplam, exatamente, o necessário e urgente redimensionamento da DAE.

O pressuposto elementar para este redimensioñamento é a explicitação de uma definida politica de assistência ao estudante na UFRJ. Já existem subsidios

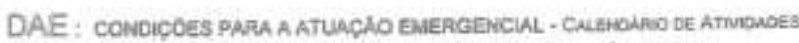

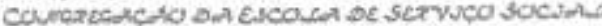

$$
10 \mathrm{ri1} / \mathrm{M}
$$




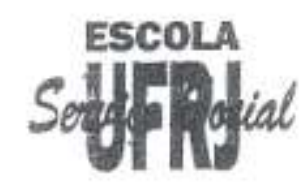

significativos - produzidos na Escola de Serviço Social, na DAE (") e também em outras universidades brasileiras - que permitem a formulaçăo rigorosa desta politica. Trabalhando a partir destes subsidios, mas considerando novas pesquisas $\theta$ contribuiçoes e adequando-as à orientação sócio-acadèmica postulada pela Reitoria, a Escola de Serviço Social oferecerá ao CEG, caso sejam atendidads as exigências minimas expostas neste documento, no próximo mès de abril, uma proposta global para a mencionada politica, de acordo com o seguinte calendário de atividades:

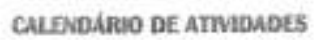

\begin{tabular}{|c|c|}
\hline DATA & ATMIDAOES \\
\hline $\left.280 \mathrm{cos} /{ }^{\circ}\right)$ & 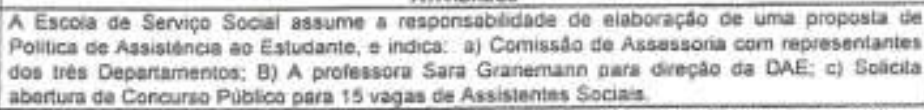 \\
\hline $05 / 10$ a $19101994(7)$ & 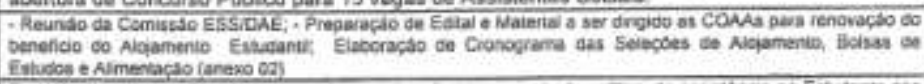 \\
\hline $0711: 94(9)$ & 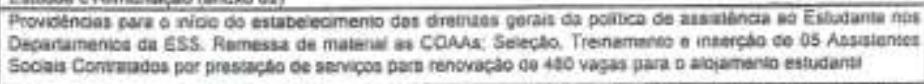 \\
\hline OQM1194 त & 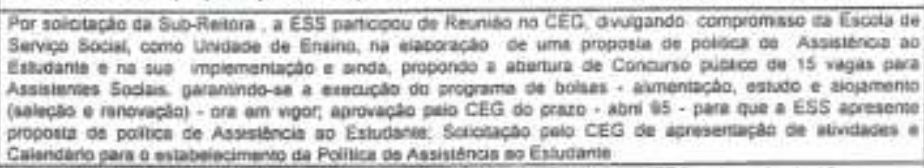 \\
\hline 16 de NOV a 10 de DEZ & 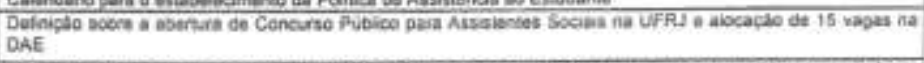 \\
\hline Dez/54 a FEV 195 & 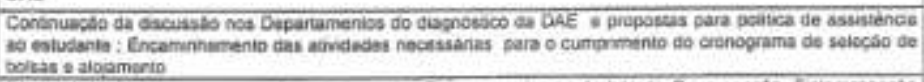 \\
\hline Marẹo/s5 & 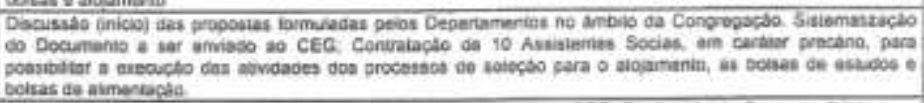 \\
\hline Abrivgs & 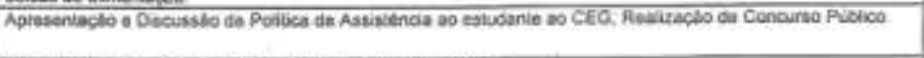 \\
\hline Maiares & Conirataclo de 15 Assisientes Sociais para a CAE \\
\hline
\end{tabular}

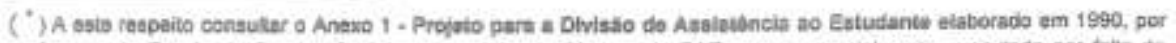
proiessera de Escoie de Servica Social, nu condicho de Diretota da DAE, apenss pareizimente axecutado por falla de provimento dos recursos matgrais a humenos cre minimamante solicitados.

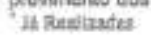

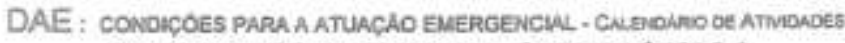

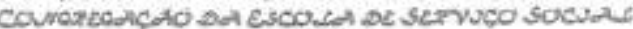

1001194 
a) uma açáo estratégica plasmada em projetos amplos e abrangentes, articuladores da politica assistencial com os principais vetores intervenientes na formação integral do estudante; nela caberá o equacionamento da nova problemática posta pelos cursos noturnos e pela particularidade caracteristica do alunado de pós-graduaçä̀:

b) uma_atuaça emergencial, configurada em serviços pontuais e focalistas.

Há um consenso entre os especialistas em politicas assistenciais: todos consideram que elas só são eficazes se conjugam organicamente estes dois niveis, jà que a atuaçâo emergencial só transcende as limitações inerentes à prestaçăo episódica de beneficios e serviços quando estâ vinculada a uma intervenção estrategicamente diferenciada.

Contudo, a realidade das carências de parte ponderável de nosso alunado näo pode esperar por uma formulaçăo estratégica: o repertório de demandas que requer atuaçẩo emergencial é muito amplo e, dada a dimensão da "divida social" brasileira, continuará requerendo a médio prazo. E esta atuaçăo emergencial nấo tem sido contestada na UFRJ: antes, vem sendo reafirmada como necessária, inclusive pelo CEG que năo tem apontado mudanças substantivas quanto à

DAE : CONDICOOES PARA A ATUACAO EMERGENCIAL - CNLENDNAD DE ATMOADES

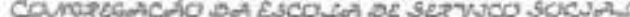
$10 \mathrm{H} 1 \mathrm{Ag}$ 
concessäo dos beneficios configurados no alojamento e nas bolsas de estudos e alimentaçầo, Por isto mesmo, também é emergencial dotar, imediatamente, a DAE de condiçōes para responder convenientemente ao elenco de demandas explicitadas a seguir:

Cronograma dos Phocessos de Selecho Paru o Alojamento as Bolsas de Estudos e

\section{BoLses de ALAMENTACHo}

\begin{tabular}{|c|c|c|c|c|c|}
\hline Deneficio & $\begin{array}{l}\text { PERIODO DE } \\
\text { inscricho }\end{array}$ & ALEUNS PROCEOAEETTOA ADOTNOOS & $\begin{array}{l}\text { DAİADE } \\
\text { REGUTADO }\end{array}$ & 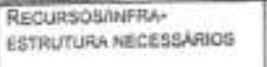 & NGUNos inschertos \\
\hline $\begin{array}{c}\text { Alojamento } \\
\text { (Renovaça) }\end{array}$ & $\begin{array}{l}09 \text { a } \\
23 / 11 / 94\end{array}$ & 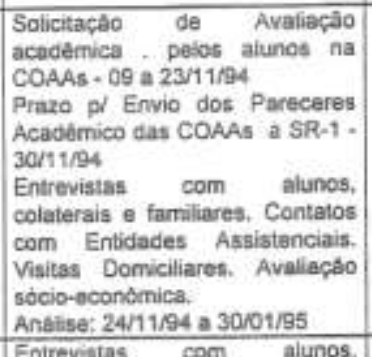 & $3001 / 1985$ & $\begin{array}{l}05 \text { A.Sociais (7 meses). } \\
01 \text { sala para } \\
\text { atendimento r e } \\
\text { entrevistas; 03 carros } \\
\text { pidia. Ielefone/fax }\end{array}$ & 480 \\
\hline $\begin{array}{l}\text { Alojamento } \\
\text { (Novas } \\
\text { Inscriçes) }\end{array}$ & $\begin{array}{l}\text { c6 a } \\
17103 / 95 \\
\text { (Inscricto } \\
\text { ploroem } \\
\text { altsb }\end{array}$ & $\begin{array}{l}\text { Enireviatas com alunos, } \\
\text { colaterais a familiares. Contatos } \\
\text { com Entidades Assistenciais. } \\
\text { Visasas Domiciliares. Avalacao } \\
\text { sbcio-economica. } \\
\text { Analiss: } 20003 \text { a } 10 / 05 / 85 \\
\end{array}$ & $\begin{array}{l}15 \text { de maio } \\
\text { de } 1995\end{array}$ & $\begin{array}{l}\text { Mesma Equipe } \\
\text { especificade no quadro } \\
\text { acima }\end{array}$ & $\begin{array}{l}250 \text { (em } \\
\text { media) }\end{array}$ \\
\hline $\begin{array}{l}\text { Bolse- } \\
\text { Alimentaço } \\
\text { Emergencial }\end{array}$ & $\begin{array}{l}\text { 04 a } \\
15 \text { vanes }\end{array}$ & 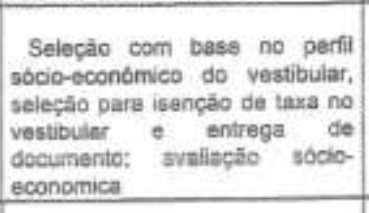 & $\begin{array}{l}17 \text { de Marco } \\
\text { de } 1995\end{array}$ & $\begin{array}{l}10 \text { Assistenles Sociais } \\
\text { (6 meses): 01 Saia } \\
\text { Para atendimento e } \\
\text { entrevistas; } \\
\text { O3 carros pidie. }\end{array}$ & $\begin{array}{l}800 \text { (em } \\
\text { Media) }\end{array}$ \\
\hline $\begin{array}{l}\text { Bolsa } \\
\text { Alimentactio } \\
\text { o Bolse ds } \\
\text { Eatudos } \\
\text { (Novos } \\
\text { Pedioios) }\end{array}$ & $\begin{array}{l}03 \approx \\
20 / 04 / 85\end{array}$ & 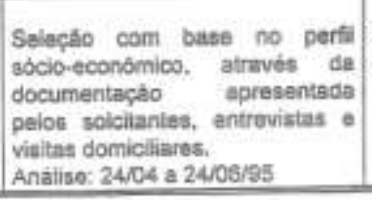 & $\begin{array}{l}30 \text { de junho } \\
\text { de } 1995\end{array}$ & $\begin{array}{l}\text { Mesma Equipe } \\
\text { especificada no quadro } \\
\text { acims }\end{array}$ & $\begin{array}{l}2000 \text { a } 3000 \\
\text { (em media) }\end{array}$ \\
\hline
\end{tabular}

DAE: CONDICOES PARA A ATUACAO EMERGENCLN-CUERTHO DEATMIONDES 
7.5.

Anexo 5 - Subsídios para uma Proposta de Política de Assistência Estudantil

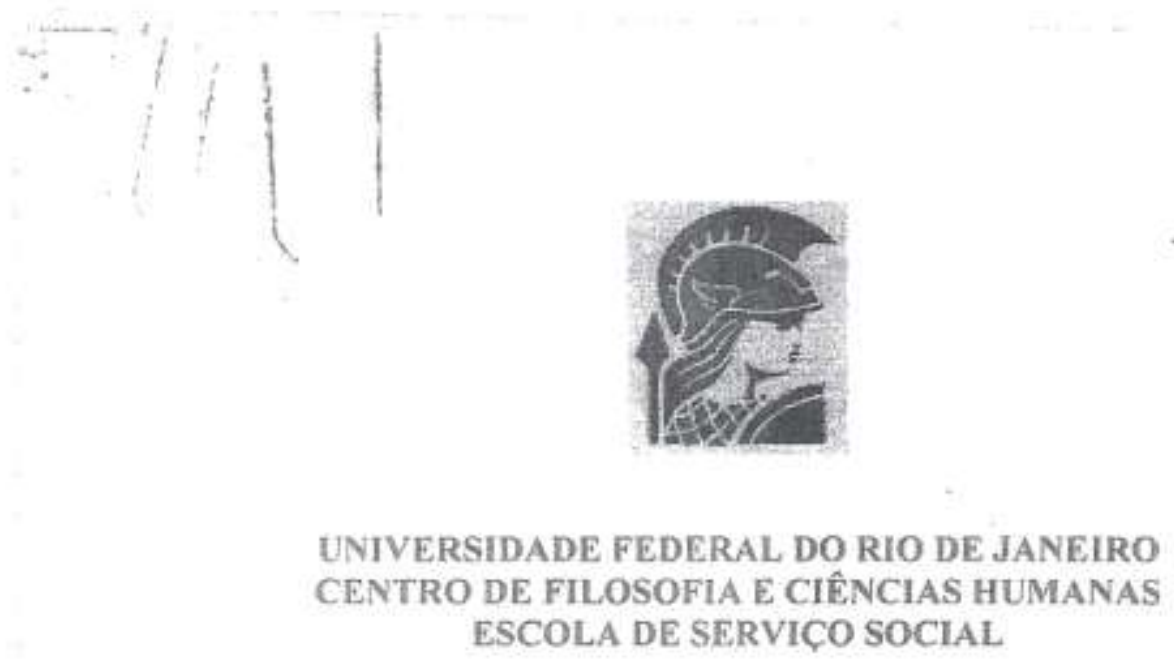




\section{INTRODUÇÃO}

Atendendo à solicitaça contida no Memorando no. 63/00. do llmo. Sr. Sub-Reitor de Ensino de Graduaçăo e Corpo Discente. o presente documento destinase a subsidiar a discussão - por parte da Câmara de Corpo Discente do Egrégio Conselho de Ensino de Graduaçĩo - sobre a elaboração de uma proposta de política de assistêncis ao estudante da UFRJ.

Parte dos principios gerais de uma politica de assistência. bem como seus pressupostos e sua regulamentaçâo em fiace à legislação vigente. Em seguida, expôe a caracterizaciio - que foi possivel traçar - do perfil sócio-econômico dos alunos que ingressaram na Universidade a partir de 1999, considerando tambem documentos produzidos pela Divisâo de Assistência ao Estudante. e por relatórios anteriormente elaborados por diferentes instâncias đa Universidade. Finalizando, propōe diretrizes para essa política no ambito da graduaçẫo.

Vale mencionar as procedimentos utilizados pela Comissão para a construçąo da presente proposta:

1) examinou em profundidade o conjunto de documentos encaminhados inicialmente;

2) a partir dessa leitura, solicitou material complementar c/ou informações a Camara ou diretamente às instâncias envolvidas;

3) procurou os diversos segmentos e setores da Universidade com o objetivo de verificar a existência de propostas e debater idéias inicinis. Desta forma, foram interlocutores: a Sub-Reitoria de Pessoal e Serviços Gerais, a Divisåo de Assistência ao Estudante, a Administraçẫo do Alojamento Estudantil, a Comissẩo de Alunos do Alojamento c Representantes discentes junto ao CEG.

Da análise do material, chama a atençâo as várias tentativas de normatização da matéria, bem como a ausencia de dados sistematizados sobre a mesma. Vale ressaltar que esses dados năo săo apresentados de per sí: estẵo envoltos em principios que - acredita a Comisslo - säo partilhados pelo conjunto da Universidade e que då significado aos dados uqui compilados.

Ressaltamos que não integrava a demanda colocada para a ESS. nem 
tampouco o material encaminhado permitiria, estabelecer metas de curto, médio e Iongo prazo. bem como detalhar programas e projetos, com suas respectivas estratégias de operacionalizaçto da proposta de politica, posto que tal tarefa necessita de informaçōes e de decisōes por parte de instâncias deliberativas e executivas desta Universidade. Desta forma. a Comissão se limita a consignar a necessidade de sua execuçăo

Cabe ressaltar que a comíssão sistematizou várias propostas já existentes no âmbito da Universidade, buscando articulá-las em torno de uma concepção de politica. destacando seus principios norteadores e apresentando-as em forma de açбes programáticas. Portanto. a proposta, longe de apresentar inovaçßes, prima em resgatar idéias já existentes e conformá-tas num escopo de politica. Sendo assim. várias das propostas aqui presentes podem ser encontradas. in tolum nos documentos consultados.

\section{BASES PARA UMA POLITICA DE ASSISTENNCIA AO ESTUDANTE}

A. Carta Constitucional de 1988, tambèm conhecida como "Constituiçầo Cidada". apresenta uma ampliaçlo no campo dos direitos sociais c eleva a assisténcia social ao słatus de politica pública.

Pela primeira vez, a assistência social é admitida como dever do Estado e direito de cidadania, integrante da Seguridade Social. assentada no tripé da saúde. previóềncia e assistência.

O cidadăo. na forma da lei, passa a ser reconhecido como sujeito da história. presente e participe na multiplicidade dos espaços seciais e políticos, apto a ter influéncià e intervençāo na direção intelectual e moral da vida pública e na defesa da democracia plena.

Embora a Constituiçâo tenha sido outorgada em 1988, somente em 1993 esta politica ficou definitivamente assegurada, a partir da assinatura da Lei Orgânica da Assistčncia Social que define que "la assistência social, direito do cidadăo e dever do Estado, ć politica de seguridade social. que provê os mínimos sociais, realizados 
através de um conjunto integrado de açōes de iniciativa páblica e da sociedade, para garantir o atendimento às necessidades básicas".

Se a assistência social era, antes da Constituição. produto de longa trajetória histórica marcada pela exacerbaçăo dos contrastes entre riqueza e miséria. ainda hoje, podemos afirmar, temos no pais um "Estado de mal-estar social" (Oliveira. 1985:5) onde as intervençōes no âmbito social, e especialmente na assistência social. vêm significando um espaço de menor relevância na administração pưblica.

A ussistência social para se confirmar como política pública obriga-se a ter como balizamento năo os necessitados, mas as necessidades sociais em sentido ilimitado. Isso indica que deve buscar garantir um padrāo minimo de vida a todo o cidadão. sem a instância da contributividade.

A fragilidade $\mathrm{da}$ cidadania nas práticas cotidianas, nầo se constituindo parte integrante das regras organizativas da vida social, o demorado reconhecimento do direito como atributo efetivo das politicas sociais, consolidando-se em práticas de incivilidade (Telles, 1992) sầo os causadores, em grande parte. da disseminaç̣̂o da representaçăo da impossibilidade da.idéia do direito a ter direitos(Arendt, 1991).

Por outro lado. configura-se ainda um quadro de bastante precariedade quanto à explicitação de uma política de assistência social ampla. de afirmaçào do campo dos direitos de cidadania. que estabeleça açôs assistenciais. competências e defina a alocaçâo de recursos para as diversas instâncias governamentais. $O$ que se manifesta sã̃o "açס̃es emergenciais e circunstanciais em que não se altera o perfil da desigualdade e se nega a dimensĩo redistributiva que deveria orientar a intervençẫo estatal no campo da politica assistencial" (Yasbek, 1993:51).

Pơr ter sido historicamente uma ärea intricada e controversa, a assistência social. apesar da garantia do direito constitucional, ainda continua sendo abordada na sua forma mais aparente: como ajuda pontual e personalizada as grupos de maior vulnerabilidade social.

Se essa perspectiva se mantiver, a assistência social năo se constituirù em politica c continuarà movendo-se num terreno marcadanente contraditório - na tenstỉo constante entre a incluș̃o e a exclusâo - assumindo por isso marcas demasiadamente conjunturnis, casuisticas. ora com caracteristicas mais generosas ora 
pouco vigorosas.

$\mathrm{O}$ cerne da efetivaçăo da assistência social como politica pública. como direito de acesso universal, cada vez mais duramente criticada pelos neoliberais. situase nĭo em seus alicerces mas fundamentaimente na sua execuç̋̋. Portanto, como diz Bobbio, o problema dos direitos sociais nã̃o ê o de justificá-los, mas de protegế-los (Bobbio:1992:24).

Nesse contexto, onde as medidas de ajuste estrutural sobrepōem-se. as politicas sociais tornam-se focalizadas, restritas aos segmentos mais pauperizados e a prestaçăo de serviços tende a ser submetida aos principios do nercado. Em outras palavras. realiza-se uma obstrução das funções públicas do Estado - a serviço da coletividade - comprometendo suas responsabilidades e obrigaçōes sociais.

Essse processo redunda na eliminaçâo dos direitos sociais de cidadania, que sô podem existir na sua universalidade, uma vez que să̊o direitos de todos diante do Estado, estatuidos das mesmas e iguais prerrogativas, advindas da condiçåo de cidadâos e cidadâs.

Por seu turno, tambem a educaçào universitaria, como politica social e pública. é expressào e resuitado do quadro desenhado pela atual conjuntura brasileira, onde as verbas vâo tornando-se a cada dia mais escassus e. sustentadas prioritariamente na lógica contábil do custo/beneficio.

No entanto, sua funçầo não se restringe somente a administrar com competência as verbas $c$ a luta pela autonomia do saber que envolve a indissolubilidade do ensino, a pesquisa e a extensão. Como toda política pública tambèm tem a obrigaçđ̃o. temporal. de não silenciar. não se alienar e, introduzir como componente dessa autonomia o estabelecimento de uma politica de assistência aos seus estudantes.

No atual contexto năo pode deixar-se ficar prisioneira dos ditames $e$ propostas do Estado brasileiro, fundadas nos principios do neoliberalismo, onde se transfere para o mundo acadêmico os mesmos padrōes que regem a compra $\mathrm{e}$ venda de mercadorias, com o risco e o agravante de estimular o individualismo.

Não obstanie as tendências variadas e até contrapostas, desde 1993, o Fórum de Pró-Reitores de assuntos estudantis e comunitários, jấ vem demarcando que 
1) "o processo crescente de democratizaçiono pelo qual vem passando o Sistema Escolar Brasileiro vem fazendo sentir-se na Universidade Pública. que passa a incorporar cada vez os estudantes oriundos de familias de baixa renda:

2) os dados têm mostrado que, embora ainda distante das proporçðes pretendidas, o número de estudantes oriundos deste segmento e egressos da escola pública tem crescido nos ủltimos anos, expressando uma tendència definida e irreversivel de democratização do espaço do ensino superior:

3) do conjunto de alunos matriculados, de $30 \%$ a $50 \%$ dependendo de cada Instituiçăo, sฐ̃o oriundos de familias com renda de até 6 sałários mínimos:

4) do conjunto dos matriculados, de $8 \%$ a $10 \%$ shio alunos que efetivamente nâo conseguem se manter, cujo quantitativo vem aumentando ano a ano, em decorrência. por um lado, do processo acelerado de proletarizacio a que vem sendo submetida a populaçāo brasileira nestes anos de crise econômica e institucional, $\mathrm{e}$, por outro, da democratizaçăo do acesso da classe trabalhadora ao sistema escolar como um todo, e à universidade em particular".

En vista desse quadro considera que:

"(...) o compromisso efetivo do Estado com a democratização do ensino superior pressupōe a criaçăo de condiçōes concretas de permanência do aluno de baixa renda na Universidade, através da formulaçăa de programas que busquem atenuar os efeitos das desigualdades existentes. provocadas pelas condiçōes da estrutura social e económica da população".

Como se pode verificar, hả um bom tempo, já está introduzida, no interior da produção universittária., a problemática da assistência aos estudantes, demarcada como responsabilidade institucional.

No entanto, cabe ressaltar. mais uma vez, que uma politica de assistência ao estudante não pode se limitar a criar e executar mecanismos destinados à populaçăo de baixa renda: ela deve. tambèm, se preocupar com principios de alendimento universal, conforme preconiza a concepçẫo apresentada inicialmente que se pauta em itstrumentos legais em vigor.

Assim procedendo, a universidade estará garantindo a efetivaçẫo da assistência ao estudante como direito, buscando realiza-la na sua plenitude. transformando-a definitivamente numa politica pública, a serviço da coletividade. sem prerrogstivas e comprometida com a democracia e o pleno exercicio da cidadania. 


\section{DADOS DISPONIVEIS SOBRE O CORPO DISCENTE DA UFRJ}

O elitismo do ensino superior no Brasil tem sua grande queda com a democratização do acesso ao ensino superior. No inicio dos anos 60 . a questão dos excedentes apitava o ensino superior no pais. Tal situaçâo reverte-se com a implantaçầo dos vestibulares clasșificatórios no inicio dos anos 70 . em que pese o aumento constante do número de candidatos por vaga, acirrando a competiçào e aumentando a frustraçẩo de contingente erescente de jovens. Por nâo conseguirem transpor as portas da universidade, atribuem seu fracasso a sua própria incapacidade. individualizando questôes relativas à própria estrutura do ensino no pais.

Nâo se pode esquecer que, paralelamente, a partir da década de 50 , ocorre tuma raipida urbanizaçāo dn sociedade brasileira, com expansão da industrializaçä̆o. modificando a estrutura ocupacional (reduçẫo da população ligada so setor primário. transferida para as ocupaçōes urbanas); com isto, aumenta a pressìo sobre a questăo do acesso ao ensino superior, bem como elevam-se as expectativas em relação ẩ inserçĩo nas novas condiçôes sociais e de produçẫo. Como consequêencia, a educaçẫo passa a ser reivindicada como um direito social.

A oferta do ensino superior, embora tenha triplicado a partir dos anos 70. è ainda insuficiente para atender à nova demanda derivada da grande expansto do ensino médio. No entanto, a elevaç̦̃o da escolaridade da populaçăo brasileira. incluindo a expansão do ensino superior. ế uma questẩo estratégica, tanto por desenvolver a competência nacional em ciência e tecnologia, condição essencial para - desenvolvimento nầo subordinado, como para assegurar a elevação da qualidade de vida da populaçâo e a redução da cxclusto social e cultural. Por isso que o governo federal investe. no plano do ensino básico, em programas de garantia de renda minima concebidos de forma articulada ao aumento da escolaridade.

Vale lembrar que na UFRJ, em 1992, houve um acrescimo de $20 \%$ nas vagas ofertadas no vestibular. "associado th abertura de 9 (nove) novos cursos. dos quais 5 (cinco) noturnos e 8 (oito) cursos que passaram a ser oferecidos, também, no periodo noturno. perfazendo um total de 17 (dezessete) novas ofertas para a 
sociedade. (...). (SR-1, 1995:3).

Questōes como essas levaram o Fórum de Pró-Reitores de Graduação das Universidades Brasileiras (FORGRAD. 1999) a estabelecer como meta a expansïo de oferta de vagas nos próximos 10 anos, de forma a atingir $30 \%$ da populaçâo de 18 a 24 anos. Obviamente, a ampliaçlo da oferta de vagas nas IES nesse periodo requer at garantia de várias condiçōes objetivas, mas principalmente, a definiçằo de programas que tornem este processo viável.

Tal tarefa não é fácil de ser enfrentada; basta lembrar que a Lei 5.540 jả espelhava a politica econômica implementada pelo regime militar. A linha diretriz. adotada pelo. Estado para atender a demanda por mais vagas no ensino superior. primou pela compatibilizaçẫo entre duas exigências contraditôrias: ampliar o número de vagas e nâo onerar os cofres públicos. Ụma estratégia foi proceder â racionalização dos recursos a partir da utilizaçâo plena daqueles já existentes. como instalaçōes, equipamentos e quadro de pessoal da esfera docente e da administração c. pela adoçâo. no âmbito da academia, de medidas tais como. criação do sistema de crédito e implantą̧ăo do ciclo bésico, entre outras.

Evidentemente, a democratização do acesso ao ensino superior alterou signifieativamente o perfil dos alunos que ingressam nos diferentes cursos do sistema superior de ensino. quue tem sofrido sensiveis mudanças em decorrência de fatores sociais e econômicos.

Pesquisa nacional coordenads pelo Fórum Nacional de Pró-Reitores de Assuntos Comunitários e Estudantis (FONAPRACE) e que foi viabilizada no âmbito da UFRJ pela Divisão de Assistência an Estudante, aponta que, do conjunto dos matriculados nas IFES. de $8 \%$ a $10 \%$ são alunos que efetivamente nฮ̃o consegueru sc manter nas Universidades Pùblicas brasileiras.

Vejamos, agora, alguns dados especificos pura a UFRJ:

QUADRO 1

Relnçấo entre vagas, candidatos e solicitaçōes de isenç̄̃ŏo da taxn de inscriçẵo no vestibular por ano

\begin{tabular}{|l|l|l|l|l|}
\hline Ano & Vagas & Candidatos & $\begin{array}{l}\text { Iseaçís } \\
\text { solicitadas }\end{array}$ & $\begin{array}{l}\text { Isenç5es } \\
\text { concedidas }\end{array}$ \\
\hline 1996 & 6.118 & 43.834 & 5.497 & 3.942 \\
\hline 1997 & 6.160 & 48.113 & 7.838 & 5.643 \\
\hline
\end{tabular}




\begin{tabular}{|l|l|l|l|l|}
\hline 1998 & 6.120 & 51.887 & 8.845 & 6.520 \\
\hline 1999 & 6.120 & 52.917 & 12.177 & 9.640 \\
\hline 2000 & 6.128 & 55.920 & 11.116 & $\begin{array}{l}7.104 \text { (integral) } \\
778 \text { (parcial) }\end{array}$ \\
\hline 2001 & 6.133 & 59.608 & 12.046 & $\begin{array}{l}8.384 \text { (integral) } \\
603 \text { (parcial) }\end{array}$ \\
\hline
\end{tabular}

0 presente quadro revela a pressto quantitativa dos candidatos pela isenção da taxa de inserição no Vestibular nos últimos seís concursos. Como pode ser observado. em 1996 os pedidos de isenção atingiram a marca de $12.54 \%$ aumentando progressivamente até 1999. quando $23 \%$ dos candidatos apresentaram esse pieito. Para o Vestibular de 2001 a taxa cai para $20,21 \%$, sendo ainda maior que o patamar de $1998(17.04 \%)$

Em se tratando de potenciais alunos (visto que esses números incluem candidatos que serão ou nåo classificados), pode ser inferido que em caso de ampliaçào das vagas para admissão na Universidade, aumentară o número de alunos que poderào demandar necessidades especiais para permanecerem na UFRJ.

Os quadros $\mathrm{e}$ tabelas a seguir apresentados foram produzidos a partir de dados relativos a os alunos classifieados para a UFRJ. Serviram de base os relatórios fornecidos pela Comissắo Executiva do Concurso de Seleçtô, que trabalha com dados desagregados por sexo, distribuidos por classificados, não classificados e de demanda geral. 
TABELA

RENDA MENSAL FAMILIAR POR ANO DE INGRESSO

\begin{tabular}{|l|l|l|}
\hline RENDA & $\mathbf{1 9 9 9}$ & $\mathbf{2 0 0 0}$ \\
\hline Até 1 salärio mínimof(SM) & 0,94 & 2.20 \\
\hline De 1 a 3 SM & 4,50 & 5,38 \\
\hline De 3 a 5 SM & 9,03 & 10.50 \\
\hline De 5 a 10 & 20,14 & 22,46 \\
\hline De 10 a 20 & 23,87 & 23.22 \\
\hline De 20 a 30 & 16,57 & 16.70 \\
\hline Maís de 30 & 19,08 & 18.06 \\
\hline Em Bnnco & 5,83 & 1.49 \\
\hline
\end{tabular}

Como pode ser observado, houve um aumento de mais de $100 \%$ entre os alunos situados na faixa de renda de até um salário minimo. Agrupando-os com os alunos situados na faixa de até 3 salários - jả que a DAE trabalha com até 2 salários temos. para o ano $2000.7,58 \%$ dos alunos classificados no vestibular em situaçảo de baixa rende.

Observando-se as respostäs para situação de trabalho de pai e mãe, para 1999 e 2000. verifica-se que: diminuiu o número de empregados, aumentou os desempregados e se manteve estavel o número de aposentados.

TABELA 2

PARTICIPAÇÃO DOS ALUNOS NA RENDA MENSAL

FAMILIAR

POR ANO DE INGRESSO

\begin{tabular}{|l|l|l|}
\hline PARTICIPAÇO & 1999 & 2000 \\
\hline $\begin{array}{l}\text { Nâo trabalha e tem seus gastos financiados pela } \\
\text { farnilia }\end{array}$ & 75,10 & 80.28 \\
\hline Trabahiha, mas recebe ajuda financeira da familia & 8,63 & 7.09 \\
\hline $\begin{array}{l}\text { Trabalha e é responsável pelo seu sustento da } \\
\text { familia }\end{array}$ & 3.56 & 3.53 \\
\hline Trabalha e contribui para o sustento da familia & 5.57 & 5.51 \\
\hline Trabalha e ć responsável pelo sustento da familia & 1.39 & 1.62 \\
\hline Em branco & 5.75 & 1.16 \\
\hline
\end{tabular}

Como pode ser observado, $24,9 \%$ dos vestibulandos classificados $\mathrm{em} 1999$ 
trabalhavam no ano do Vestibular; esse dado cai no Concurso de 2000 (19.72\%). No entanto. a opçẫo de maior ocorrência nẫo esclarece se esses alunos não trabalham porque não conseguem ser absorvidos no mercado de trabalho ou porque não têm necessidade: esse dado, pensado com o aumento de alunos na faixa da renda familiar mais baixa. pode expressar a dificuldade de inserção no mercado de trabalho. principaimente em funçăo da Tabela a seguir.

\section{TABELA 3 \\ EXPECTATIVA DE TRABALHO DURANTE O CURSO POR ANO DE INGRESSO}

\begin{tabular}{|l|l|l|}
\hline EXPECTATIVA DE TRABALHO & 1999 & 2000 \\
\hline Näo & 6,38 & 6,90 \\
\hline Sim, apenas em estágio para treinamento & 36,21 & 37,72 \\
\hline Sim, apenas nos últimos anos de estudo & 7,69 & 8,59 \\
\hline Sim. desde o 1 ano, em tempo parcial & 37,00 & 38,88 \\
\hline Sim, desde o I' ano, em tempo integral & 6,94 & 6.92 \\
\hline Eim branco & 5,78 & 1,09 \\
\hline
\end{tabular}

A partir dos dados dessa tabela, podemos inferir que um nùmero significativo de alunos que não trabalhavam de época do Vestibular, pretendem diminuir a relaçăo de dependência financeira com a familia. Chamam atenção os alunos que desejam urabalhar em tempo integral desde o $1^{*}$ ano $(6,92 \%)$, o que pode significar tratar-se de população potencial que requer atendimento especial pela politica de assistẻncia ac estudante.

O próximo quadro revela a incapacidade de absorçăo da demanda; mesmo no ano em que se dả um maior atendimento (1999), 35.24\% dos solicitantes não puderam ser absorvidos no Alojamento da Universidade, o que pode servir de estimativa para sua ampliaçâo. Vejamos os dados: 
QUADRO 2

MOVIMENTAÇÃO NO ALOJAMENTO POR ANO

\begin{tabular}{|c|c|c|c|c|}
\hline ANO & RENOVAÇĀO & & SELECCAO & \\
\hline 96 & 396 & $\begin{array}{l}\text { Demanda } \\
283\end{array}$ & $\begin{array}{l}\text { Admissão } \\
121\end{array}$ & $\begin{array}{l}\text { Renda Familiar Per Capita } \\
78 \% \text { de } 1 / 2 \text { SM a } 11 / 2 \text { SM } \\
22 \% \text { de } 1 \frac{1}{2} \text { a } 3 \mathrm{SM}\end{array}$ \\
\hline 97 & 379 & 241 & 77 & $\begin{array}{l}42,9 \% \text { ate } 1 \mathrm{SM} \\
54.5 \% \text { de } 1 \text { a } 2 \mathrm{SM} \\
2.6 \% \text { de } 2 \text { a } 21 / 2 \mathrm{SM}\end{array}$ \\
\hline 99 & 373 & 259 & 79 & $\begin{array}{l}49,5 \% \text { até } 1 \mathrm{SM} \\
48,2 \% \text { de } 1 \text { a } 2 \mathrm{SM} \\
2,3 \% \text { de } 2 \text { a } 21 / 2 \mathrm{SM} \\
41,9 \% \text { até } 1 \mathrm{SM} \\
41,9 \% \text { de } 1 \text { a } 2 \mathrm{SM} \\
16,2 \% \text { de } 2 \text { a } 4 \mathrm{SM}\end{array}$ \\
\hline
\end{tabular}

0 quadro seguinte apresenta a distribuição dos alunos por diferentes estratos sociais. Vale ressaltar que a pesquisa se pautou em classificaçăo sócio-econômica estabelecida pela Asssociaçāo Brasileira de Institutos de Pesquisa de Mercado (ABIPEME), que trabalha com base no acesso aos serviços e bens de consumo da familia dos entrevistados.

\section{QUADRO 3}

Estratificação dos Alunos de Gradunç⿰ฺ็ da UFRJ

\begin{tabular}{|l|l|l|}
\hline Classe & Frequêencia Absoluta & Freq̨uência Relativa \\
\hline A & 120 & $13.8 \%$ \\
\hline B & 467 & $53,9 \%$ \\
\hline C & 227 & $26,2 \%$ \\
\hline D & 45 & $5,2 \%$ \\
\hline E & 8 & $0,9 \%$ \\
\hline Total & 867 & $100 \%$ \\
\hline
\end{tabular}


Pelos critérios da ABIPEME, os alunos da UFRJ estăo concentrados na classe B: $6.1 \%$ encontram-se nas classes D e E. podendo ser considerados como um grupo de baixa renda.

Enfatiza-se como un dado a mais que em 1996 existiam na UFRJ 2.000 cotas de bolsas assistenciais (distribuidas entre bolsa alimentaçầo - 1.500 e bolsa de estudos - 500), perfazendo um percentual aproximado de $6,06 \%$ do total de alunos.

O conjunto dos dados aqui apresentados indicam que podemos estimar a taxa de $8 \%$ para o grupo de alunos que seriam cobertos de forma especial pela politica de assistência ao estudante. A base de projeçtio leva $\mathrm{cm}$ consideração que o indice estabelecido pelo FONAPRACE situa-se na faixa de 8 a $10 \%$ e os dados especificos da UFRJ. apesar da diversidade de criterios de ciassificação, giram em torno de 6 a $8 \%$.

O reflexo dos fatores subjacentes à emergência deste novo perfil, rebate sobre as instituições formadoras de mâo-de-obra qualificada, como mostra estudo realizado por Costa (1991) sobre o fenòmeno da evasão. Dentre os vários motivos apontados pelos alunos para abandonar ou se afastar do curso, estâo, além de necessidade de trabalhar, outros como. por exemplo, dificuldade de conciliar estudo $\mathrm{c}$ trabalho; necessidade de estudar à noite; alto custo dos cursos oferecidos pelas instituiçōes privadas, entre outros.

De fato, näo basta estabelecer metas de ampliação de vagas no ensino superior; há que se definir mecanismos de fixação desse tåo novo quadro de alunos que está ingressando na Universidade; do contrário, continuaremos com altas taxas de evasão.

Por este conjunto de questôes. o Fórum de Pró-Reitores de Graduaçūo estabelece como meta para a graduação nacional, no que diz̃ respeito â financiamento e fomento, "institucionalizar Programas de Boisas para estudantes. Nias diferentts IES, deverío ampliar-se, com recursos próprios e de instituiçôes governamentais, programas PET, PIBIC e de bolsas para monitoris, extensåo e estrigios, allados a um sistema de bolsas que permita ateuder às necessidader de alunos economicamente necessitados."

Isto implica também em ume determinadin concepção de gratuidade; para 3 ANDES (1996:29) esta compreende "n⿳亠丷厂 s6 a ausência de taxas ou mensalidades. 
mas a garantia de reais condiçoes de estudo, através de sisternas e mecanismos que permitam â aluno condiçōes de alimentação, transporte. moradia. disponibilidade de material de estudo."

Isto posto, considerando que a proposta do Plano Nacional de Educação. elaborada pelo Executivo e encaminhado ao Congresso Nacional (1998) prevê - ao lado de mecanismos de ampliaçăo de vagas no ensino superior - a criaçlo de condiçōes que facilitem "ìs minorias, vitimas de discriminação, o acesso à Educaçâo Superior". a formulaçẳo de uma política de assistência ao estudante urge.

\section{III - PROPOSTA PARA A POLITICA DE ASSISTĖNCIA AO ESTUDANTE}

\subsection{Princípios Norteadores da Politica de Assistência ao Estudante}

- A educaçấo será desenvolvida com base, entre outros, no princípio da igualdade de condiçôes para o acesso e permanência na escola - Artigo 206. Inciso 1 da Constituição da República Federativa do Brasil e Artigo 3. Inciso I da Lei de Diretrizes e Bases da Educaçâo.

- A assistência social ể um direito de cidadania garantida constitucionalmente, assentada no tripé da seguridade social e regulamentada pela Lei Orgânica da Assistência Socią.

- A Politica de Assistência ao Estudante deve estar organicamente articulada a Politica Acadêmice.

- A Politica de Assistẻncia ao Estudante deve garantir as seguintes dimensöes: apoio ao desenvolvimento acudêmico: suporte psicossocial; condiçōes de moradia: acesso à alimentaçlo. à saúde $e$ ás atividades sócio-culturais e esportivas; além de alternativas de transporte aos locais das atividades académicas. 


\section{- $\quad 3.2$-Objetivos}

- Garantir o apoio necessário al plena realização do aluno como universittário (acadèmico, cultural, social e politico).

- Desenvolver, para os alunos de baixa renda, mecanismos que promovam condições sócio-econômicas que viabilizem a permanência e o sucessso dos mesmos na universidade.

\section{- $\quad 3.3$ - Estratérias}

- Criaçầo de um conjunto articulado de programas e projetos destinados ao corpo discente. estabelecendo açס̃es voltadas para:

- a) o universo dos alunos da UFRJ;

- b) o conjunto dos alunos de baixa renda (aproximadamente 2.700 alunos):

- c) os alunos beneficiados pelo auxilio moradia ( 504 alunos).

- Valorização dos recursos da Universidade para implementar os Programas propostos. através da potencialização dos espaços físicos/serviços existentes o articulaçäo das diversas instàncias universitárias.

- Criaçâo de uma Comissäo de Acompanhamento da Implementaçầo da Politica de Assistencia ao Estudante formada pela Cîmara do Corpo Discente do CEG. pela SR-4 e pela DAE, para elaborar os. Programas propostos em termos de metas. prazos e prioridades a serem estabelecidos, assim como monitorar todo o processo de implementaçåo da politica.

- Criaçấo de Grupos Executivos com o objetivo de operacionalizar os programas aprovados, sob a responsabilidade das Sub-Reitorias envolvidas.

Pressupostus: 
- Os Programas de Assistęncia aos Estudantes de Graduação poderâo ser cumulativos.

- Todos os prédios e campi da UFRJ devem ser adequados para a circulaçắo de pessous portadoras de necessidades especiais (rampas de acesso, elevadores. banheiros, salas de aula, transporte ete.).

- 3.4.1 - Programa de Desenvolvimento Téenico-Cientifico

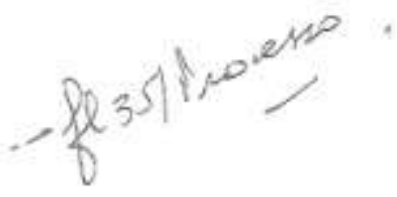

- Obietivg: Apoiar o desenvolvimento téenico-cientifico dos alunas da UFRJ. através de bolsas que viabilizem a permanencis dos alunos na Universidade e contribuam para sua formaçüo intelectual, acadèmica e profissional.

- Afũes:

- Programa de Desenvolvimento Téenico-cientifico sená constituido de quatro modalidades de apoio:
a) bolșa de iniciação cientifica;
b) bolsa de monitoria;
c) bolsa de estágio:
d) bolsa de extenșa c
c) auxilio ao estudante de baixa renda.

\section{Diretrikes:}

- Para o detalhamento deste programa sugerimos a Resoluçlo CEC 01/94 como referència.

- Apenas o auxilio ao estudante poderá ser acumulado com uma outra modalidade de apoio do Programa de Desenvolvimento Téenico-Cientifico. pois o mesmo destinase a criar condiçoes pera a permančncil dos alunos de baixa renda na Universidade. Entendemos que 0 aluno de baixa renda. ao receber o auxilio ao estudante, atinge a um patamar de condiçilo sócio-econômica próxima dos demais alunos, portanto com direito a concorrer às demais modalidades de apoio.

- A estimativa anual para a coberturs total do Auxílio ao Estudante deve ser da 
ordem de 2.700 cotas. Cabe ressaltar, mais uma vez. que as metas a serem atingidas a curto, médio e longo prazo, bem como a natureza do auxilio (serviços ou renda) e seu aporte (valor) serão definidas pela Comissăo de Acompanhamento da Implementaçăo da Politica de Assisténcia ao Estudante.

- A "Contra-partidn" do aluno que recebe o Auxilio Estudante é a manutenção de seu CR. no minimo, igual à média do CR do seu respectivo Curso.

- Todos os alunos de baixa renda que forem beneficiados com uma vaga no alojamento possuirão o Auxilio ao Estudante.

- As bolsas de estägio devem seguir as, regulamentações académicas estabelecidas pelos cursos a que elas se destinarem e respeitar a Lei 6.494/77. evitando. desta forma, sua utilização como precarizaçâa do trabalho.

- A bolsa de estágio deverá ser destinada, prioritariamente, aos alunos inseridos no Programa de Auxilio Moradia/Alojamento Estudantil. que näo possuam outra modalidade de apoio ao desenvolvimento técnico-cientifico. Somente após o preenchimento do referido critério é que outros alunos da UFRJ poderl̃o concorrer à bolsa de estagio. dando, ainda, prioridade aos alunos de baixa renda.

- As bolsas de monitoria e iniciaçẫo científica deverâo ser impiementadas de acordo com a Resoluçẫo CEG 01/94.

-

\subsection{2 - Programa de Sanide e Apoio Psicossocial}

- Obietivo: Propiciar atendimento médico-odontológico e apoio psicossocial aos alunos da UFRJ tanto em situaçóes de emergência como ambulatorial.

\section{- Acôes:}

- Atendimento médico-odontológico, pelo HUCFF e pela Faculdade de Odontologia. aos alunos tanto em situaçōes de energência como ambulatorial, al ser acondado 
com as unidades envolvidas.

- Organizaçào de atividades (palestras, encontros, seminários ete.) de caráter preventivo e informativo sobre temas relevantes para juventude.

- Desenvolvimento de assistência social e psicológica coordenada pela DAE (Divisăo de Assistència ao Estudante), atravès de articulação com a Escola de Serviço Social e com o Instituto de Psicologia, com abrangéncia para o conjunto da universidade, a ser articulado com as unidades respectivas.

- Efetivaçato de seguro para os alunos que desenvolvem atividades curriculares que caracterizam situaçōes de periculosidade.

- $\quad 3.4 .3$ - Programa de Acompanhamento Acadêmico e Suporte ao Ensine

- Objetivo: Garantir condições de apoio ao ensino e efetivar açōes de acompanhamento academico.

- Acōes:

- Efetivaçăo real da orientaçắo acadêmica nas unidades (COAA e CPO).

- Funcionamento das bibliotecas e laboratórios em horário integral, até o encerramento do curso noturno.

- Funcionamento das bibliotecas e laboratórios aos sábados das $10 \mathrm{~h}$ às $14 \mathrm{~h}$.

\section{- 3.4.4- Programa Cultural, Artistico e Esnortivo}

- Objetivo: Articular e coordenar açōes que promovam a ampliação do universo sociocuitural e artistico dos estudantes. bem como sua inserçīo em praticas esportivas.

\section{- Acóes:}

- Estabelecimento, em comum acordo com a Faculdade de Letras, de programa de ensino de linguas estrangeiras 
- Garantia da qualidade do serviço ef́etivado pelos Laboratórios de Informática em todas as unidades da UFRJ

- Criaçăo de centros de convivência universitária, favorecendo o acesso do alunado às atividades artistico-culturais

- Expansão de programas de incentivo à prática de esportes, através de articulaçẫo com a Escola de Educą̧ăo Fisica

- Reforma das quadras esportivas da UFRJ

- 3.4.5 - Programa de Auxilio Moradia/Alojamente Fstudantii

- Qbietivo: Garantir moradia para alunos que dela dependam para sua permanência na Universidade.

\section{- Diretrizes:}

- Manuicnçẫo do critério de elegibilidade para o preenchimento das vaigas do alojamento baseado na articulaçẩo dos indicadores referentes à renda e à distâncin do local de moradia do aluno.

- Os alunos de baixa renda e moradores do alojamento terão prioridade na concessalo do auxilio ao estudante de baixa renda. Os alunos do alojamento que năo receberem o referido auxilio terâo prioridade nul concessâo de bolsa de estágío. Desta forma, assegura-se algum tipo de modalidade de desenvolvimento técnicocientifico para o conjunto dos alunos do alojarnento.

\section{- Acōes:}

- Reforma total do alojamento em todos os aspectos: estruturat. instalaçôes clétricas e hidráticas, pintura. esquadrias, telefones entre outros.

- Manutençăo permanente do Alojamento 
- Retomada e avaliaçẫo do projeto original para o Alojamento Estudantil, visando a sua ampliação

- Construça de uma cozinha comunitária para administração e utilizaça dos próprios moradores;

- Instalação de uma lavanderia com a mesma finalidade. sendo o suporte téenico oferecido pela universidade;

- Instalaçäo de sala de estudos para propiciar a realizaçẫo de atividades em grupos.

- 3.4.6-Programa de.Apoio ao Transporte

- Objetivo: Garantia de um sistema de transporte adequado que circule pelos campi:

\section{- Açôes:}

- Diminuição dos intervalos dos ónibus internos em todos os tumos:

- Manutenção das linhas externas universitárias: Fundåo-Praia Vermelha-Fundão: Fundāo-Praça XV-Fundz̃o: Fundilo-Bonsucesso-Fundão, principalmente nos horírios de grande fluxo.

- Solicitaçăo à SMTU para que as empresas de ônibus aumentem a frequência das linhas que circulam na Cidade Universitária no periodo notumo e nos finais de semann.

- Retomada do projeto de construçẫo da Estaçăo do Fundâo da Linha 1 do Metró.

- Implantaçåo de programas de transporte intermunicipal de universitärios junto ás Prefeituras do Estado do Rio de Janeiro.

- V - SUGESTÃO DE ORGANIZAÇÃO INSTITUCIONAL 
- Os Programas peridos diretamente pela DAE poderĩo ser:

- Programa de Desenvolvimento Técnico-Cientifico: auxilio ao estudante de baixa renda e Bolsa de Estágio

- Programa de Saúde e Apoio psicossocial - Articulado com as seguintes unidades: Hospital Universitario, Faculdade de Odontologia, Escola de Serviço Social e Instituto de Psicologia.

- Programa de Auxilio Moradia

- Programa Cultural - Articulado com as seguintes unidades: Fórum de Ciência e Cultura/ Escola de Educação Física/ Faculdade de Letras/ Escola de Belas Artes/ Escola de Músical Escola de Comunicaçăo/ Núcleo de Computaçữo Eletrônica

- Programa de Apoio ato Transporte

- A DAE poderá ser reestruturada em tomo destes programas

- O Programa de Acompanhamento Actedemico e as Bolsas de Iniciaç̃̃o Científica e de Monitoria poderão ser gerençiadas pela Sub-Reitoria de Graduaç̣̆o.

- VI - AVAliação

- Deve sêr criado um sistema de acompanhamento/monitoramento do auxilio ao estudame de baixa renda $c$ do auxilio moradia que avalie anualmente esses beneficios.

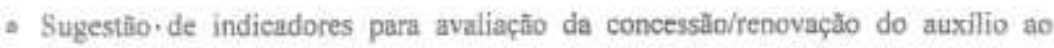
estudante de baixa renda e auxilio moradia

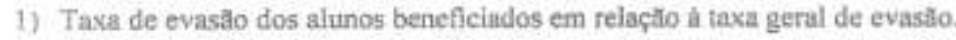

2) Tempo de integralização do curso do aluno beneficiado em relaçăo a tempo médio de conclusão do curso.

3) CR do aluno beneficiado em reiaçẵo ao CR médio do Curso 
4) Manutençlio da condição de baixa renda.

Rio de Janeiro, setembro de 2000

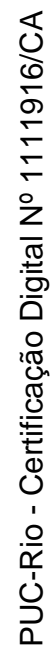




\section{Bibliografia}

ANDES. Proposta da ANDES/SN para a Universidode Brasileira. São Paulo: junho de 1996.

ARENDT. Hannah, $A$ condį̧̣ăo humana, 5,ed, Rio de laneiro: Forense, 1991.

BOBBIO, Norberto. A era dos direitos, Rio de Janeiro: Campus, 1992.

BRASIL. Lei $n^{0}$ 8.742, de 07 de dezembro de 1993. Lei Orgânica da Assistêneia Social - Brasilia, Ministério da Previdència e Assistência Social - MPAS - 1997. $2^{\text {n edictio. }}$

COSTA. Maria Fernanda T. B. Evasão no Serviço Social: análise sobre evasāo de alunos nos cursos de graduaçẫo em Serviço Social da PUC-RJ e UFRJ. (Dissertaçẫo de Mestrado en Serviço Social). Rio de Janeiro: PUC, 1991. mimeo.

FÓRUM Nacional de Pró-Reitores de Assuntos Estudantis e Comunitários. Propesta de politica de apoio ao estudanie. Brasilia, junho de 1993.

FÓRUM de Pró-Reitores de graduação das Universidades Brasileiras (FORGRAD). Plano Nocional de graduaçăo: um projeto em construçâo. Joāo Pessoa: maio de 1999.

FURTADO. Sônia Maria Romeiro, OLIVEIRA, Egléubia Andrade de e MAGALHAES, Rosélia Pinheiro de (org.). Perfil sócio-económico e cultural dos estudiantes de graduaçāo da UFRJ. Rio de Janeiro. UFRJ, 1998, mimeo.

MEC. Plano Nacional de Edtucação: proposta do exectutivo ao Congresso Nacional. Brasilia, 1998.

OLIVEIRA. Egleubia Andrade de. Assisténcia ao estudante e cultura política mo espaço universitúrio. (Dissertaçı̃o de Mestrado em Serviço Social). RJ: ESS/UFR], [997, mimeo.

OLIVEIRA. Francisco de. Além da transiçăo, aquêm da imaginação. Nowos Estudos CEBRAP. Sao Paulo. CEBRAP n" 12, junho de 1995, 2-15.

PAURA. Simone Giglio. U/ma visäo dos programas assistenclais na Universidade Federal do Rio de Janeiro e na Universidade do Extado do Rio de Janeiro. (Monografia de Ėspecialização em Politicas Sociais). Rio de Janeiro: FSS/UERJ. 1997. mimeo.

SUB-REITORIA DE ENSINO DE GRADUAÇẢO E CORPO DISCENTE. Projeto 
Académico de Graduaçâo. Rio de Janeiro: UFRJ, 1995.

TELLES. Vera da Silva A cidadania inexistente: incivilidade e pobreza - um estudo sabre o trabalho e a fanilia na Grande Säo Paulo. Tese de doutorado apresentada ao Departamento de Sociologia da USP). São Paulo: USP, 1992. mimeo.

YASBEK. Maria Carmelita. Classes subalternas e assistência social. São Paulo: Cortez, 1993.

\section{Documentos Consultados}

- Constituição da República Federativa do Brasil / 1988. São Paulo, Editora Atlas S.A. 1990 .

- Descriçăo das Atividades da DAE.

- Documento de Reivindieaçâo. ahunos do alojamento, 2000.

- Lei de Diretrizes e Bases da Educaçẫo Nacional - LDB Lei 9394 de 20/12/96. Brasilia: Congresso Nacional, 1996.

- Lei de Regulamentação de Estägio 6,494/77 de 07/12/1977. Brasilia: D.O de $09 / 12 / 1977$.

- Programa de Apeio à Formação Acadêmica de Graduacialo - PROFAG. SubReitoria de Pessoal e Serviços Gerais. Rio de Janeiro; UFRJ, 2000.

- Projeto de Assistència Estudantil da UFRJ, DAE, 1999.

- Projeto de Assistência Estudantil, estudantes da UFRJ, 2000.

- Relaça Estatistica da Incidencia de Respostas á Pesquisa sócio-cultural (19962000).

- Relatório de Atividades - Gestão julho/1994 a setembro/1995.

- Relatório de Atividades 1995, 1996 e 1998.

- Relatório de Gestâo da DAE, $1994 / 1998$.

- Relatorio de Renovaçăo do Alojamento (1996, 1997. 1998 e 1999).

- Relatório de Seleção do Alojamento (1995, 1996. 1997, 1998 e 1999).

- Relatório do Alojamento Estudantil da UFRJ, s.d.

- Resoluçāo CEG 01/94. Rio de Janeiro: UFRJ. 1994 
7.6.

Anexo 6 - Programa de Apoio ao Estudante da UFRJ

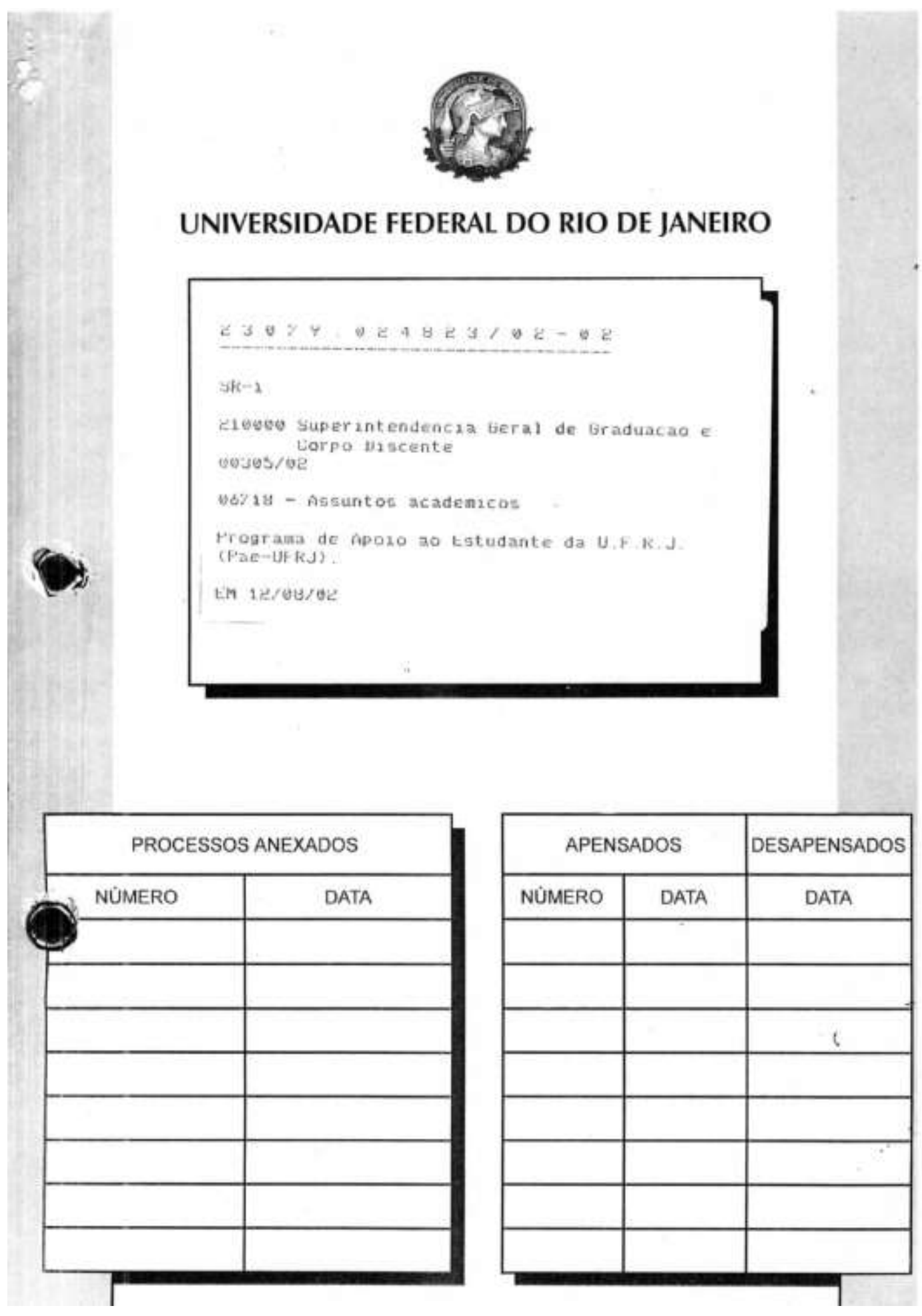




\begin{tabular}{|c|c|c|}
\hline (86) UNIVERSIDADE FEDERAL DO RIO DE. JANEIRO & \multicolumn{2}{|c|}{$23079.024823 / 02-02$} \\
\hline REQUERIMENTO & 305 & $\begin{array}{c}\text { DATA: } \\
\text { 12.08.2002 }\end{array}$ \\
\hline
\end{tabular}

PARA: DICOM

INTERESSADO: Sub-Reitoria de Ensino de Graduação e Corpo Discente

ASSUNTO: Programa de Apoio ao Estudante da Universidade Federal do Rio de Janeiro - (PAE - UFRJ)

TEXTO

Ao DICOM para formar processo e posterior envio a Secretaria do CEG.

Em 12/08/2002

Hodingeifle.

MEIENA RODJGUES ROCHA

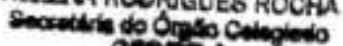

oes 


\section{PROGRAMA DE APOIO AO ESTUDANTE DA UNIVERSIDADE FEDERAL DO RIO DE JANEIRO - (PAE - UFRJ)}

A nova reitoria da Universidade Federal do Rio de Janeiro, a maior Instituição Federal de Ensino Superior do pais, através do Programa de Apoio ao Estudante de Universidade Federal do Rio de Janeiro (PAENFRJ), destinado aos estudantes de baixa renda, aprovados no Concurso de Seleção perspectiva para que estes escăo da UFRJ (Vestibular), vem oferecer uma real com exclusividade, assumindo desempenho no seu respectivo curso. compromisso em manter um bom em um contexto institucional, vincu. Trata-se de um Programa novo, inserido UFRJ

\section{Normas para concessão de bolsas de estudo PAEUFRJ}

Artigo $1^{\circ}$ - Os alunos dos Cursos de Graduação da UFRJ poderão solicitar bolsas de estudos PAENUFRJ, à Divisão de Assistência ao
Estudante (DAE), SR-1.

Artigo $2^{\circ}$ -

O CEG, semestraimente, será informado pela SR-1 da dotação orçamentária disponivel, fixando o número de bolsas de estudos a serem concedidas, assim como seu valor mensal.

Artigo $3^{\circ}$ - Os boisistas PAENIFRJ deverâo manter atividades acadêmicas em tempo integral e dedicaçăo exclusiva.

Parágrafo Único - Será permitido ao aluno do PAENFRJ acumular outras modalidades de bolsa, respeitando-se os dispositivos legais e as resoluçōes especificas da UFRJ.

Artigo $4^{\circ}$ - A duraçăo da bolsa de estudo será de doze meses, renovável nấo podendo exceder a média entre o tempo mínimo e o máximo para integralizaçăo curricular. 
Artigo $5^{\circ}$

$$
\begin{aligned}
& \text { Ocompanhamento dos bolsistas será efetuado pelos } \\
& \text { Professores-Orientadores designados pelas Comissర̋es de } \\
& \text { Orientaçåo e Acompanhamento Acadêmico (COAAs) des } \\
& \text { Unidades. }
\end{aligned}
$$

Artigo $6^{\circ}$ -

a) estar regularmente seguintes requisitos:

deveré pricitação da bolsa de estudo do PAENUFRJ, o candidato

recomendadas pela Coordenação de Orientaçāo e Acompanhamento
Acadêmico (COAA);

b) Acadêmico (COAA);

comprovada;
grau de dificuidade sócio-económica efetivamente

c) nâo ter sofrido sançăo disciplinar.

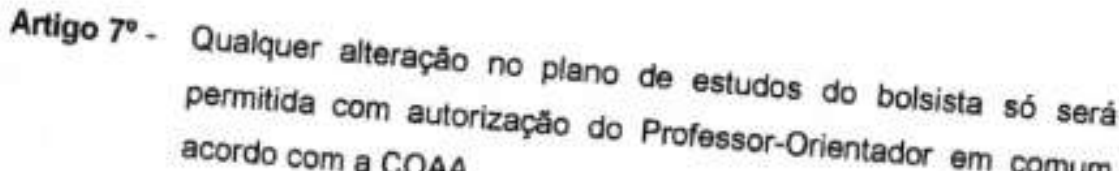

Artigo $8^{\circ}$ - A renovaçăo

anualmente, mediante:

beneficiário, sob responsabilidade da DAE

b) avaliação do desempenho acadêmico DAE

parecer circunstanciado emitidêmico do aluno beneficiário, mediante

em que estiver regularmente considerar, inclusive, o prazo matriculado, devendo o parecer A estabelecido no Artigo $3^{\circ}$. indicado pela SR-1, Centro de UFRJ.

Artigo $10^{\circ}-0$

S casos omissos serão analisados pelo CEG. 
197

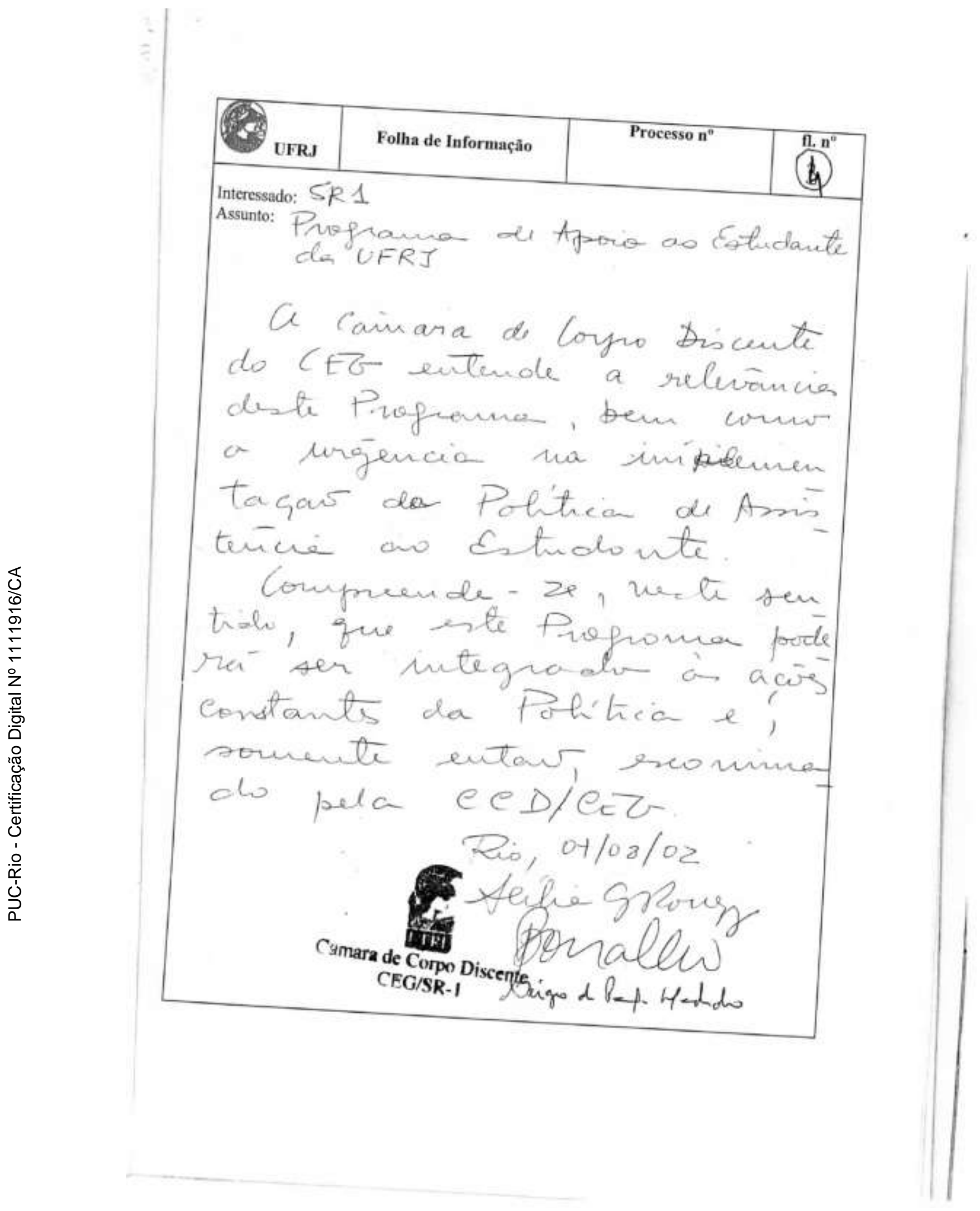


(9)

PROGRAMA DE BOLSAS INSTITUCIONAIS (PBI) INTEGRADO À POLÍTICA ACADÊMICA DA SR-1/UFRJ E AOS PROGRAMAS DE APOIO E ASSISTÊNCIA ESTUDANTIL (PAES)

PROPOSTA APRESENTADA PARA GESTÃO 2002-2006 DA SUB-REITORIA DE ENSINO DE GRADUAÇÃO E PESQUISA -

PROF". SYLVIA DA SILVEIRA MELLO VARGAS

PROF ALBERTO SCHANAIDER 


\section{PROGRAMA DE BOLSAS INSTITUCIONAIS (PBI) INTEGRADO À POLITICA ACADÊMICA DA SR-1/UFRJ E AOS PROGRAMAS DE APOIO E ASSISTENCIA ESTUDANTIL (PAES)}

Entre os graves problemas que afligem a geståo acadêmica institucional ao longo dos últimos anos destaca-se a oferta de bolsas: A ausência de uma política acadêmica de apoio e o preocupante cenário atual. O projeto governamental para a educação, fruto de um modelo que relega a graduação a um plano secundário, eivado de propósitos mercadológicos e meramente quantitativos, restringiu ainda mais o aporte de verbas e consequentemente comprometeu as metas de ampliação da concessào de bolsas, no âmbito institucional

A gestão, que ora se inicia, assumiu o compromisso de, en um primeiro momento e de modo emergencial, ampliar o quantitativo de bolsas para alunos de baixa renda. Portanto, a nova Reitoria irá destinar cerca de $50 \%$ das verbas do gabinete para tal fim, compreendendo cerca de 250 novas bolsas. Este ato, mais do que um mero acréscimo numérico sinaliza à comunidade acadêmica da UFRJ a firme intençlo para enfrentar uma conjuntura critica e que irá requerer a somi de esforços, a médio e longo prazo, no intuito de suprir as reais necessidades de nossa
instituição.

O panorama atual é sombrio, pois contamos, thio somente, com cotas de bolsas para os alojados referentes ao Programa de Formação Acadêmica da Graduaçăo (PROFAG) sob controle da SR-4, aquelas relacionadas à Iniciaçâo Cientifica (cotas institucionais do CNPq e balcão) e as do Programa Especial de Treinamento da CAPES (PET), ambas sob a égide da SR-2.

Uma consulta à Resoluçâo CEG 01/94 evidencia a diversidade existente naquele ano, compreendendo outras modalidades de bolsas, tais como as de: Licenciatura, Iniciação Artística e Cultural, Estágios Profissionalizantes, Jovem Cientista, Intemato e Monitotia. A compreensào não oferece garantias minima fragilidade de um sistema que compromete o papel social institucional, e as desigualdades e nâo estimula o aprimoramento discente. As metas institucionais oầ devemtrastes se restringir apenas aos alunos de baixa renda discente. As metas institucionais nåo devem formação e à qualificação acadêmicas. Aproximadamente 2700 alunos, cerca de $8 \%$ dos classificados no vestibular, estâo
inclusos na faixa de renda mensal de até três salários mínimos (Dados obtidos de documento produzido pela Comissão Assessora da Càmara de Corpo Discente do CEG - setembro 2000) e o beneficio alojamento atende a 504 alunos. 


\section{Propostas e Estratégias:}

Encaminhamos, pois, algumas sugestōes e que se estruturam em uma perspectiva realista:

Reestruturar internamente a SR-1, congregando o Programa de Bolsas Institucionais em uma seçî̀o própria da Divisło de Ensino (para as bolsas acradêmicas) e na DAE (para as bolsas de estudantes de baixa renda e para o beneficio moradia) da qual participem representantes destas duas divisōes, dos alunos (do DCE, do alojamento e do CEG), membros da Câmas destas

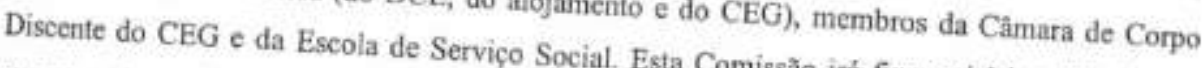
metas, cuja regulamentação deverí ser aprecial. Esta Comissão irá fixar critérios, diretrizes e e avaliar o Programa, de forma permanente.

Viabilizar o Programa de Bolsas

compreendendo Programas de Apoío e Astionais inserido em uma Política Acadêmica conjuntas com a Reitoria, a Prefeitura a SR-3.teincia Estudantil (PAES), formalizando açôes cmpresas, os órgåos conveniados eoutros or

Cumpre, em um breve histórico, dirrmir al organismos nacionaìs e internacionais

terminologia das Bolsas. Até 1988 existia uma critérios sócio-econômicos e destinada aos alunos der Serviços Prestados relacionada a Ensino ou em outros órgĩos da aprovadas pelo CEG (Resolução 3/89), sem vinculaçâo acadèmica obrigatória, Em normas (mantida cm sua finalidade pela Resolução $1 / 94$ ) PROFAG, cujo gerenciamento e implecte denominação de bolsa Até 1992, os alunos fazianto implementação coube a SR-4.

fechamento dos referidos restauma suas refeiçôes nos bandejões da UFRJ, quando $\mathrm{cm}$ face do alojados eram contemplados com ex desmembradas do benefício no forma, nem todos alunos alojados pasesâo de residência no alojamento estudantil). Desta Alojamento foi incorporada à SR-4.

Considerando que, na gestāo anterior, no que tange ao alojamento e às diretrizes e normas para a concessão das bolsas, houve um esvaziamento das atribuiçōes da SR-1 c do CEG, não causa surpresa que o cenário atual seja reflexo da đesorganizaçăo e acefalia administrativas.

Lembramos a existência de bolsas vinculadas a estágios em empresas c cujo controle de bolsas słło sugeridas para implantação futura,

Estud Licenciatura

\footnotetext{
studante de Baixa Renda, Monitoria
} 
Estudante de Baixa Renda - Destinada a da concessão do benefficio moradia: Ela alos alunos de baixa renda, independentemente alimentaçào. Esta bolsa poder ser acu. Ela atenderia, também, as necessidades do auxilio

Monitoria - Destinado ao alumo com aprovein as outras modalidades. que visa a participaçåo deste em ativides destoveitamento acima da média dos seus pares e e competência, sob supervisåo docente (Resoldáticas do Departamento, dentro de sua capacidade título no Histórico Escolar, haja vista a (Resolução especifica: 8/70). Sugerimos a inclusẫo deste

Internato - Específicas partêância acadềmica do mesmo.

de plantão. (à exemplo dos cursos de: Mue cumpram atividades acadêmicas em regime Nutriçầo).

Estágio - Visará atividades relacionadas à área de formação do aluno, em especial aquelas de caráter artistico, cultural e desportivo, incluindo a dimensẵo performática. Devem ser ofertadas, prioritariamente, aos alunos de baixa renda. Alguns cursos terão previsão de bolsas
para estágios profissionalizantes e de cunho administrativo.

Iniciaçâo Científica (PIBIC. Programa de Bolsas

da cota institucional atenderá, preferencialmente, Bolsas de Iníciação Científica) - A oferta cientifica regular e relevante conforme crittrios doutores ou pesquisadores com produçäo pesquisadores que já detenham cotas oriundaśos emanados pelo órgão competente. Os Programa Especial de Treinamento (PET) contemplados, via de regra receberào uma (01) bolsa. Desta forma outras agências de fomento, caso da cota institucional a um universo maior de besta. Desta forma, será exequivel a distribuiçào grupos de pesquisa emergentes.

Licenciatura - Destinada aos alunos inseridos $\mathrm{cm}$ atividades desenvolvidas junto ao consino fundamental e médio e que contribuam para a formação de professores. Deverà, também, contemplar os alunos de Licenciatura que participem de projetos e de pesquisas educacionais elaborados por docentes que nào tenham obtido bolsas na modalidade de Iniciaçăo Cientifica.

Em todas as modalidades de bolsas será considerada, para efeito de concessåo, on renovaç̃o, a análise do desempenho escolar do aluno a ser cfetuado pelo Orientador/Tutor, ou pela COAA da Unidade Acadêmica, de acordo com resoluçōes especificas (CEG). Enfatiza-se que, a concessão de moradia ao estudante (alojamento) nã̃o se constitui uma modalidade de bolsa, mas um beneficio concedido pela DAE de acordo com resoluçẫo CEG pertinente a assunto. Todavia, os alunos que auferirem tal condiçăo, quando da renovaçâo do beneficio moridia, deverầ, do mesmo modo, se submeter à análise dos seus indicadores desempenho
escolar. 


\section{Sugestôes para captação de recursos:}

A possibilidade de investimentos provenientes de instituiçôes variadas (BNDES, Banco Mundial, multinacionais e congêneres) deve ser aventada, sempre com o intuito de reverte-los na ampliação de Bolsas de Apoio ao Estudante de Baixa Renda ou cm Programas de Apoio c Assistência ao Estudante.

Bolsas na modalidade Internato já são concedidas em açồes isoladas de Unidades Hospitalares. É preciso incentivar esta iniciativa, com a participaçào das Unidades Acadêmicas. No entanto, faz-se mister normalizi-las no âmbito da UFRJ e integra-las em um cantrole único junto à SR-1 (Programa de Bolsas Institucionais), sem interferência na autonomia dos órgãos suplementares que as ofertam.

O NCE oferece algumas dezenas de bolsas do tipo estágio para alunos da área de informática (profissionalizante). Poder-se-ia interagir com a COPPE, o Instituto de Biofisica entre outros e que compõem a estrutura da UFRJ, visando ampliar este horizonte. Por suposto, esta opção irá demandar regulamentaçầo especifica e requerer adequado acompanhamento institucional.

Várias empresas solicitam à UFRJ estagiários para trabalhar em suas instalaçòes. Os diversos convênios celebrados permitem aferir o grande interesse pelos nossos alunos. Com uma vertente profissionalizante associada ao cumprimento de um requisito curricular, há um evidente aproveitamento do aluno dentro das necessidades empresariais. Além do cuidado em preservar e garantir a vinculação pedagógica do aluno em seu estågio, poder-se-ia sugerir uma contrapartida espontânea ao investimento público para a formação do aluno, já que a empresa se utiliza de alunos mais qualificados cursando os periodos finais dos cursos de graduaçìo. Esta subvençâo seria destinada, exclusivamente, à criação de Bolsas de Estudante de Baixa Renda.

Outra fonte de arrecadaçalo de recursos orçamentários para o Programa de Bolsas Institucionais proviria do coneurso de Vestibular. Óbviamente, seria preciso reavaliar os custos deste concurso e otimizar os gastos, orientando o lucro, porventura existente, para as necessidades gerais da SR-1 (incluido o referido Programa), haja vista tratar-se da estrutura superior responsável pela captaçào e geraçāo dos mesmos. 
A Câmara de Corpo Discente do CEG

Em 12 de agosto de 2002.

Heacurculte

Interessado: Sub-Reitoria de Ensino de Graduação e Corpo Discente.

Assunto: Programa de Apoio ao Estudante/SR-1.

HEIENA RODRIGUES ROCH

socretirie do Opdo Coleginevo

cease-1

Vide paveur do camare is bs. $35<36$.

Em 29/08/2002.

troou veralle

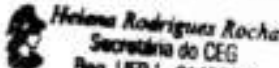

Ane UTAN-0143512 


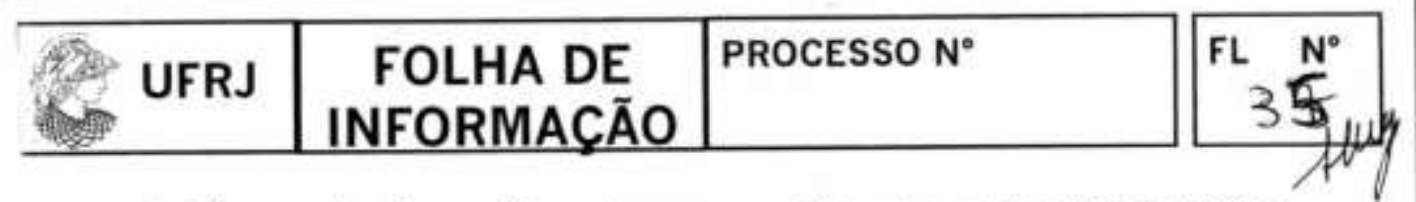

A Câmara de Corpo Discente em reunião com o Magnífico Reitor, Prof. Carlos Lessa, a Sub-reitora de Graduaçäo e Corpo Discente, Profa Sylvia Vargas e o Superintendente de Graduação e Corpo Discente, Prof. Alberto Schanaider, decidiu recomendar a implantação do auxílio ao estudante de baixa renda, no contexto do Programa de Desenvolvimento Técnico-Científico da Política de Assistência ao Estudante aprovada, por unanimidade, no Egrégio Conselho de Ensino de Graduação, em setembro de 2000. Nesta ocasião foram consensuadas os seguintes encaminhamentos:

1. A implantação será realizada a partir de recursos oriundos da verba do Gabinete do Reitor $e$,

2. $O$ auxilio beneficiará, no primeiro semestre de implantação, 250 (duzentos e cinqüenta) estudantes, dos quais 150 (cento e cinqüenta) vestibulandos e 100 (cem) veteranos.

Em 19 de setembro de 2002

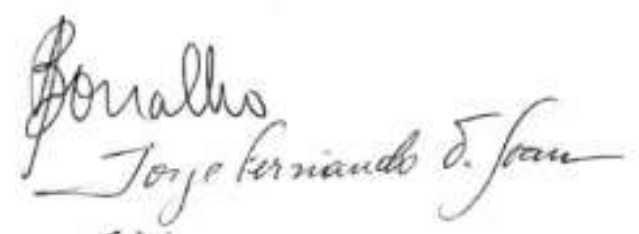

Fallio gamus

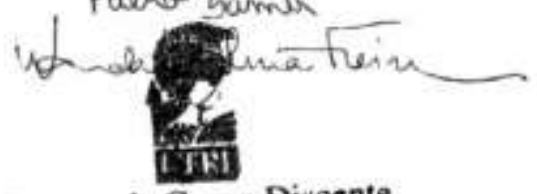

Camara de Corpo Discente

CEG/SR-1 


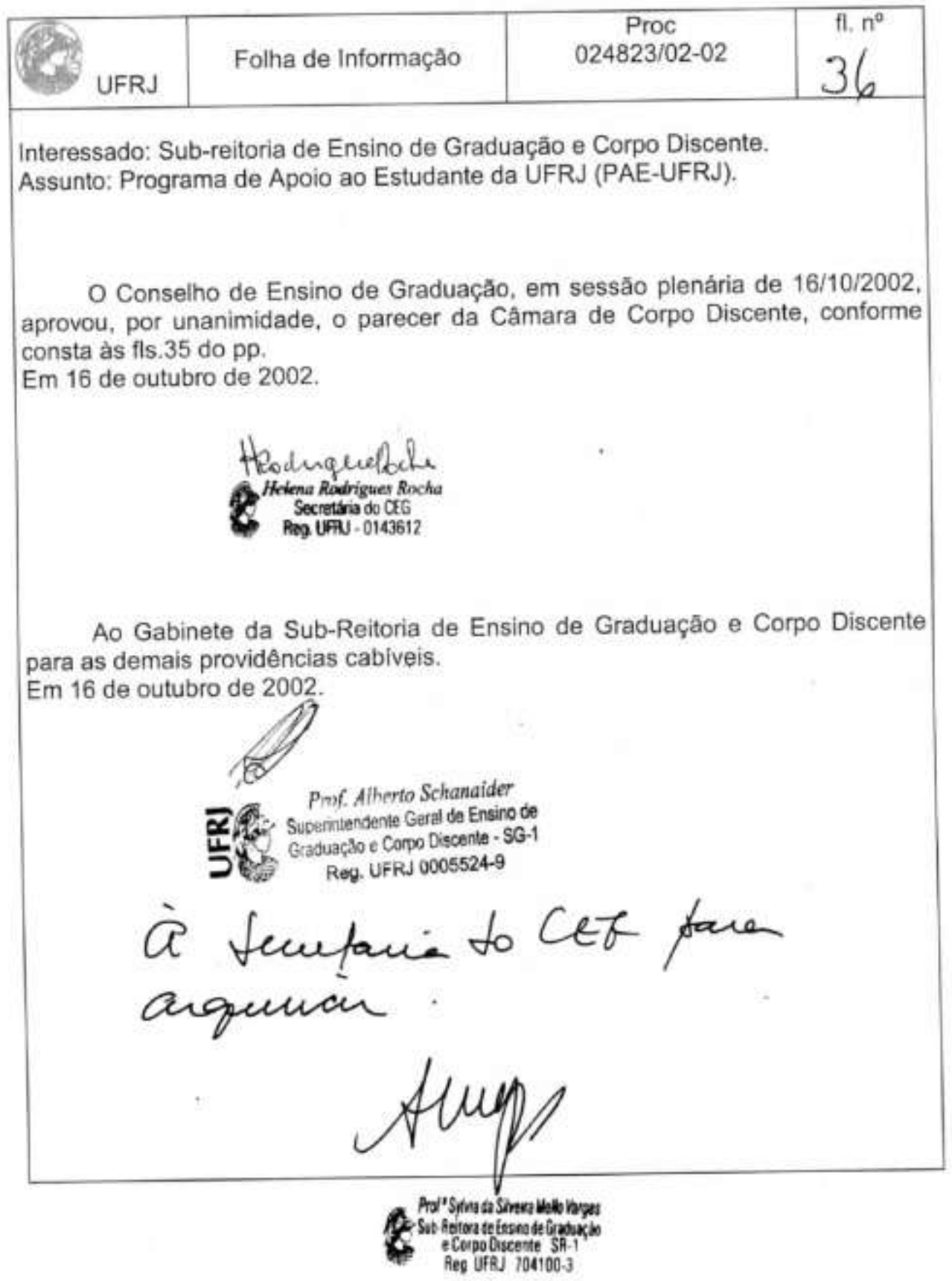

